\title{
EAST AFRICA
}

$A N D$

ITS BIG GAME
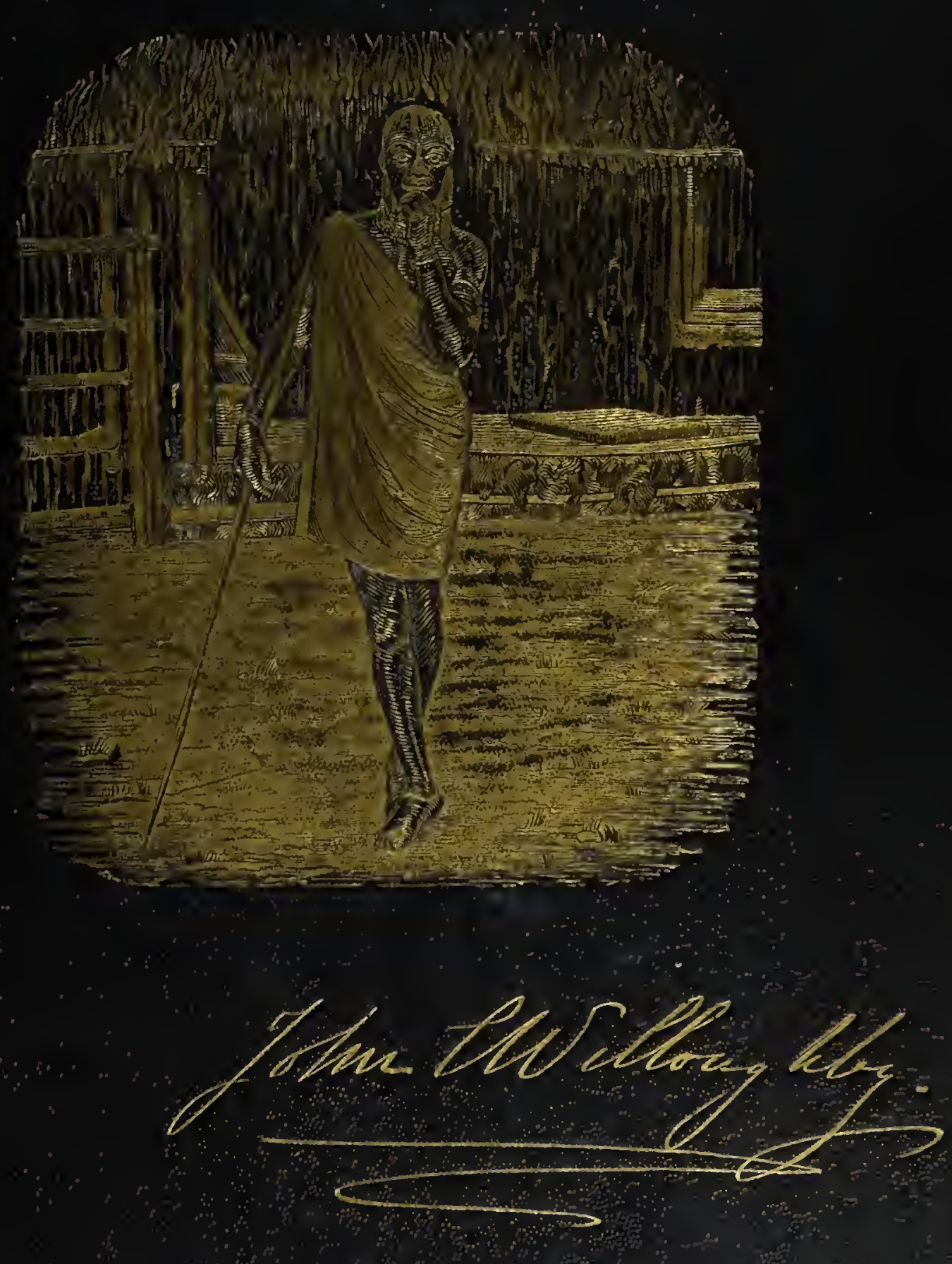


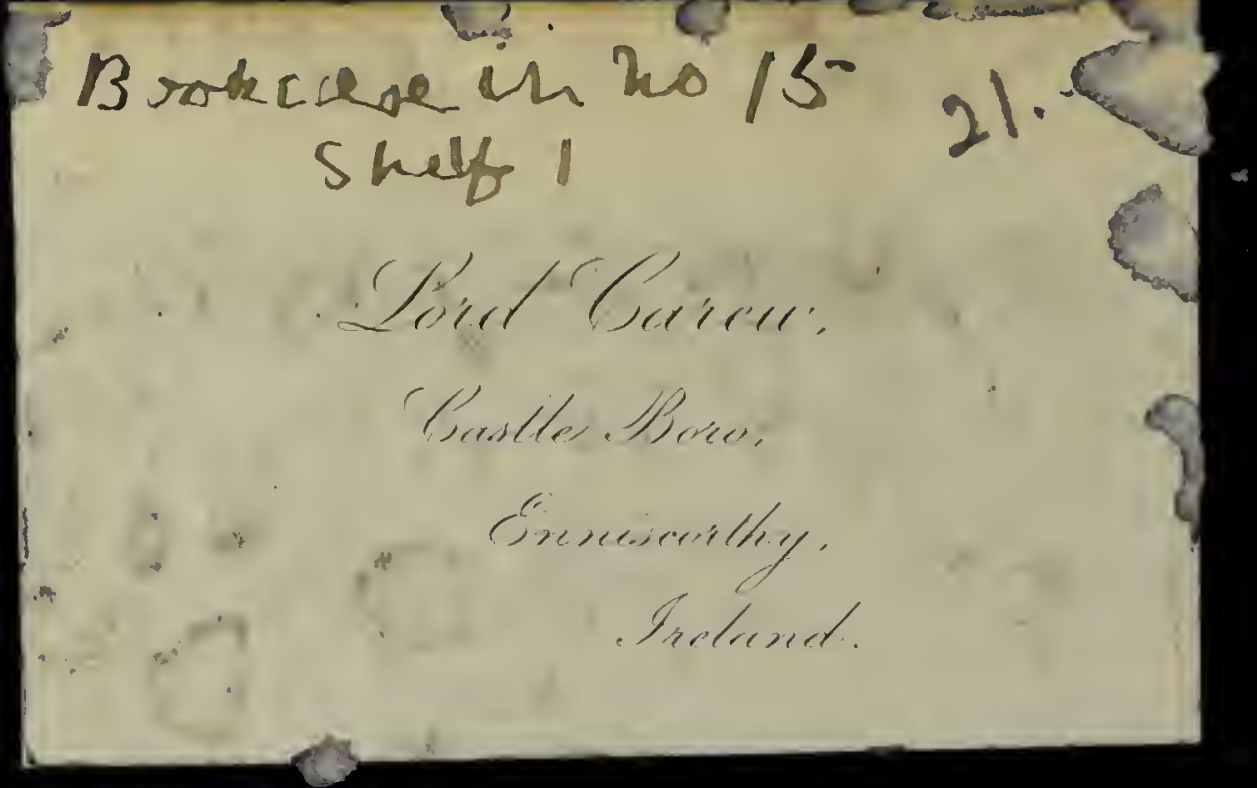

WILLOUGHBY (Captain Sir John C.)

EAST Africa AND Its Big Game: the Narra-

tive of a Sporting Trip from Zanzibar to

the Borders of the Masai, with a Postcript

by SiR R. G. HARVEY, folding map and 18

illusts., 8vo, cloth, scarce, 1889 .

$18 /-$

Willoughby (Sir John C., R.H. Guards) EAST AFriCa and its Big GAME: Narrative of a Sporting Trip from Zanzibar to Kilimanjaro and the Borders

of the Masai, illustrations from photographs, roy. 8vo., cl., 1889

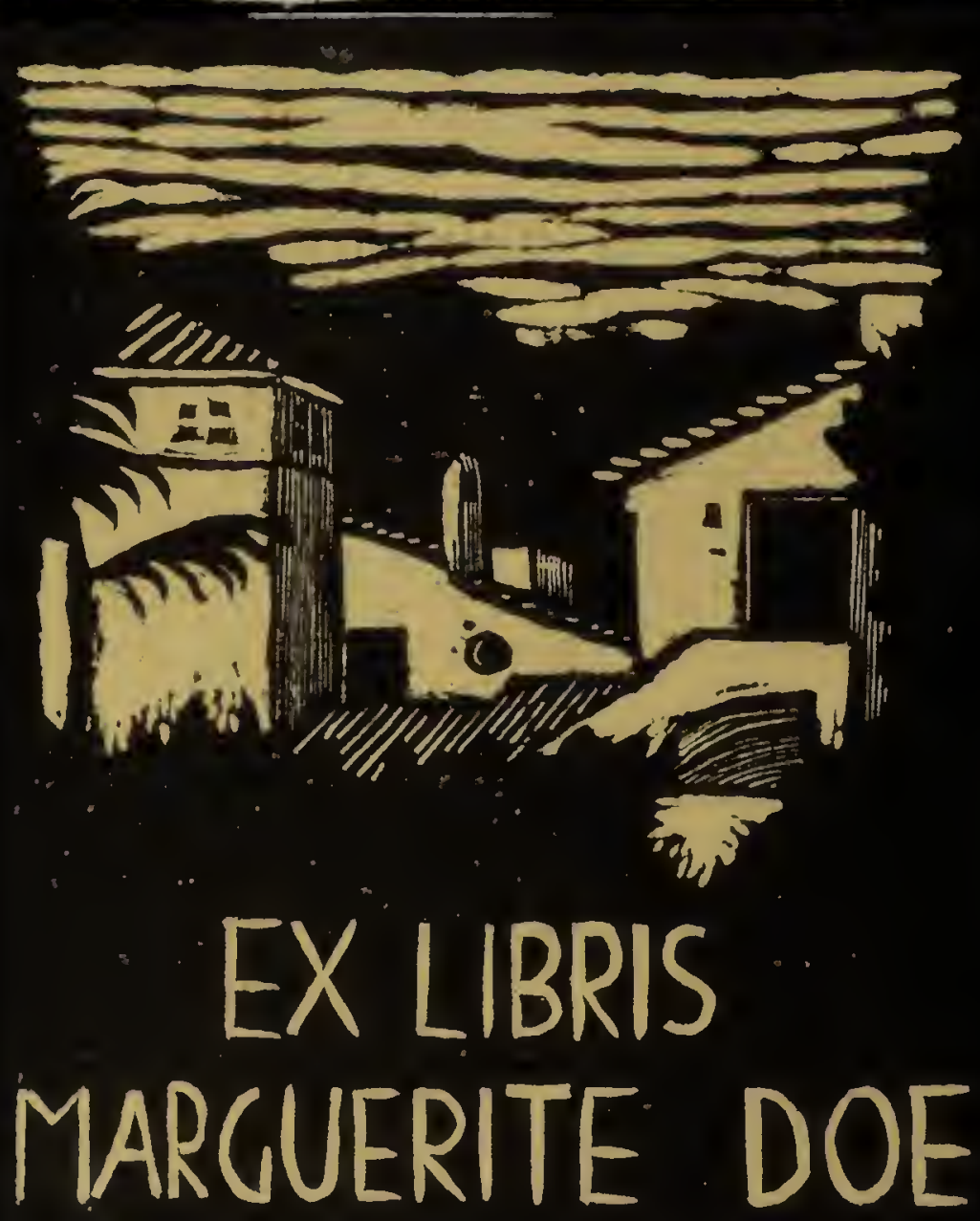

Natural History Museum Library

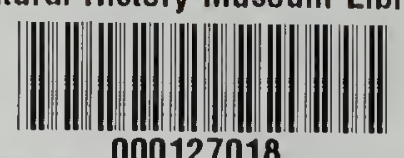




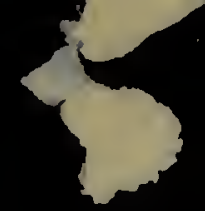

I

$-$

$\checkmark$ 
74
0
Wil 
Cares

march $15^{n}-1890$

EAST AFRICA AND ITS BIG GAME. 

4<smiles>[CH]CC</smiles>

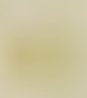




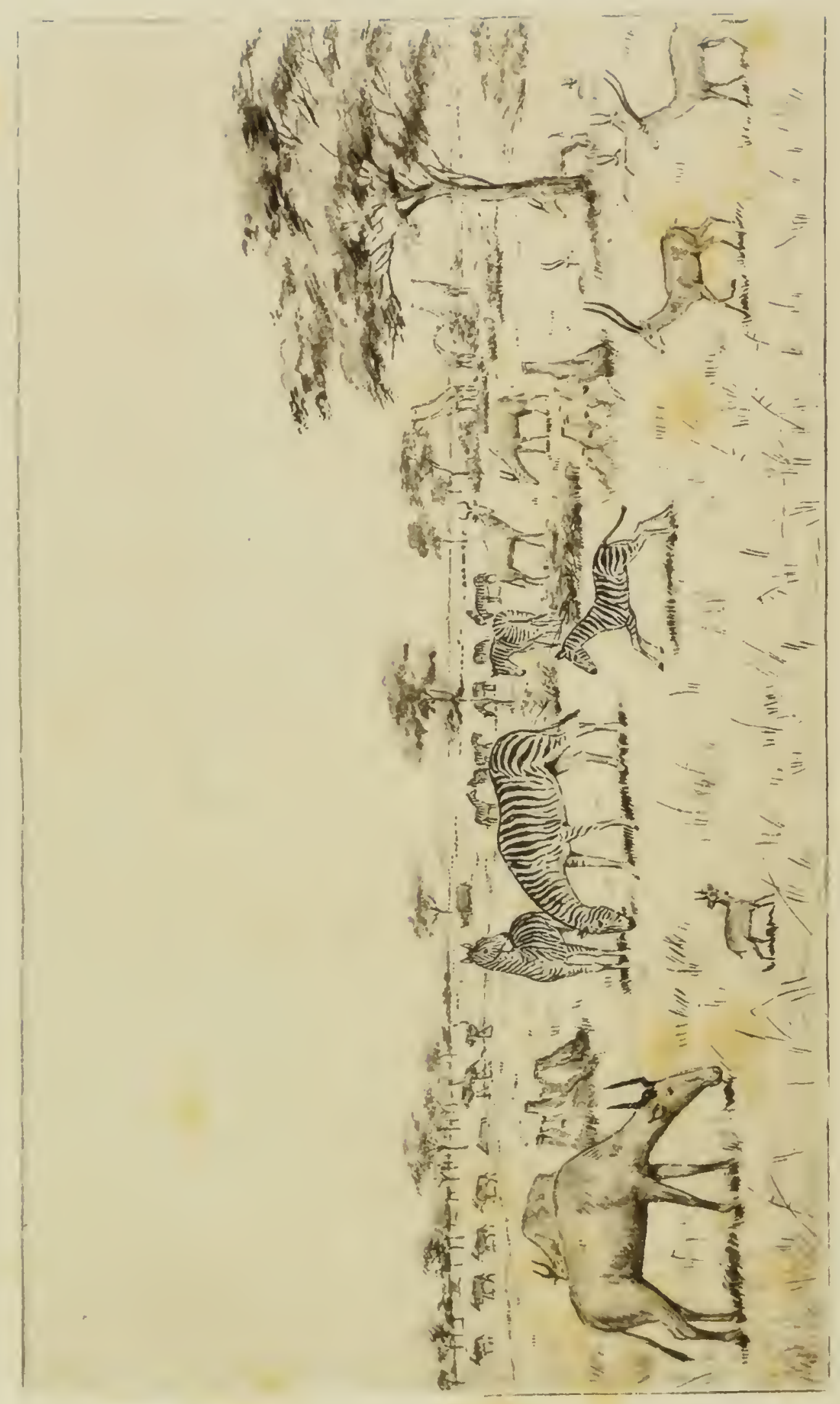




\section{EAST AFRICA AND I'TS BIG GAME}

THE NARRATIVE OF A SPORTING TRIP FROM ZANZIBAR

TO THE BORDERS OF THE MASAI

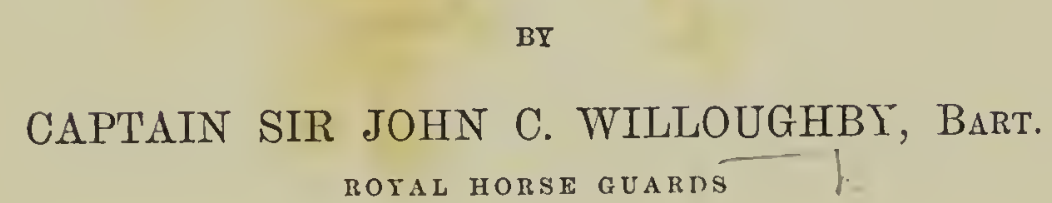

ROTAL HORSE GUARDS

WITH POSTSCRIPT BY SIR ROBERT G. HARVEY, BART.

ILLUSTRATED BY G. D. GILES AND MRS. GORDON HAKE

THOSE OF THE LATTER FROM PHOTOGRAPHS TAKEN BY THE AUTHOR

\section{LONDON}

L O N G M N S, GRE EN, A N D CO.

AND NEW YORK: 15 JAAST 16 th STRFET

1889 

HIS ROYAL HIGHNESS IHE PRINCE OF. WALES, K.G.

BY WHOSE KIND SUGGESTION THIS NARRATIVE

WAS UNDERTAKEN,

AND IN HUMBLE ACKNOWLEDGMENT OF THE VALUABLE ASSISTANCE:

RENDERED BY HIS ROYAL HIGHNESS TO THE

AUTHOR'S PARTY AT ZANZIBAR. 
howerel unattractive, has at least the merit of being truthful.

A special interest may perhaps be claimed for any book dealing with East Africa, considering the disasters which have recently overtaken German enterprise in those parts. However, I have found it quite enough for my untried hand to deal with facts, and to exclude as much as possible speculative fancies.

'The success attending our venture was mainly due to the raluable assistance we received from Sir John Kirk, late II.M.'s Consul-General at Zanzibar ; from General Mathews, Mr. Binns, the missionary of Rabai, and from the late Bishop Parker. 'l'o all these gentlemen I owe a deep debt of gratitude. I also have to thank Mr. Godfrey 'Thrupp for the literary supervision of my manuscript. I would say, in conclusion, that should any of my comments on various matters hereafter give offence, I shall be truly sorry, it having been far from my intention to hurt the feelings of any one. 


\section{CON'L E T'S.}

CHAPTER I.

The origin and olject of the Expedition-Preliminary arrangements PAGE -Departure for Zanzibar-Lamu-Arrival at Zanzibar . .

\section{CHAPTER II.}

Zanzibar-Mr. Holmwood-General Mathews-Route selectedGrave Island-Reception by the Sultan . . . . . 6

\section{CHAP'TER III.}

Presentation of letter to the German Society-The General's ruseThe Slave Trade-Mbweni and the Mission station-Missionaries in general and in particular . . . . . .

CHAPTER IV.

Departure from Zanzibar-Arrival at Mombasa-The GovernnrFreretown Mission Station-Final arrangements for the Interior -Mr. Shav's objections . . . . . • • 27

\section{CHAPTER V.}

Toyage in the dhow-The first camp-Rabai-Effect of Masai raiding-The complete cararan-Mission men against ZanzibarisDeserter's

\section{CHAPTER VI.}

The Wa-nyilia-A lioness-Sable antelope-The Doruma-Taro-A dry camp-A forced march in search of water-Maūingu-MIr. Wray-The Ndara range-The Wa-teita • • • • • 44

\section{CHAPTER VII.}

Jovia-Native purchases-Mbugoli and his warriors-Kilima-njaro sighted-Wanton attack on a slave caravan-A weary waterless journey-Arrival at Lanjora-Abundance of game-Tareta forest 


\section{CHAPTER VIII.}

Tareta camp-The effect of shooting a girafie during the marchPAGE Tareta forest-The Wa-taveta-Discharge of the Mission menHouse-building, drinking, and dancing-A deatl-Departure of $\mathrm{B}$ - and Mr. Jackson-Game-pits-A disgusting ceremony .

\section{CHAPTER IX.}

Sport at Lanjora-Return to Tinveta-Departure for Mandara's country-H_-'s first buffilo-Arrival at Moěi 96

\section{CHAPTER X.}

Mr. Fitch, the missionary-Our reception by Mandara-His habits and diplomacy-His allies and warriors

\section{CHAPTER XI.}

Religious and matrimonial ceremonies of the Wa-moči-Customs and superstitions-Physical features of the country-Mandara's presents-Photographic efforts-Mandara's return visit-The lion-trap-Reflections.

\section{CHAPTER XII.}

My first rhinoceros-Eland-Arrival of $\mathrm{C}$ - A trip to Lake Jipé -Mpallah and water-buck-A good haul of fish-Return to Taveta

\section{CHAPTER XIII.}

Game abundant and various-The Useri and their chief-Shameful treachery of a slave-trader-A tough rhino-A capital morning's sport-Rhinoceros tricornis-A native scrinmage and feast-dance -Effective charge of a rhino calf . . . . . . 146

\section{CHAPTER XIV.}

A river encampment-A good day's sport, and a narrow shave-A donkey in trouble-Return to Simba camp-Lake ČalaCharacteristies of the rhinoceros.

\section{CHAP'TER XV.}

Tareta-Attack on a Swahili cararan-The loss of a wife-Arrival of the Bishop of Mombasa-Domestic troubles-The start for Mount Mer'u-Abundance of large game-B_-'s narrow escape - Kahé forest-The Wa-kahé-Mutinous porters-Short pations -The Mount Meru trip abandoned on account of the Masin-A ludicrous Masai scare-The Sogonoi mountains . . . . I69. 


\section{CHAP'TER XTI.}

My first buffalo-The first lion bagged by C_- Alligators-Surrounded by buffalo-The bush-buck-The W'Arusha-Baboons and wildebeest-My first lion-A buffilo and a rhino secured with a right and left shot-B_- attacked by a buffaloW'Arnsha thieves - Visit to Sina

\section{CHAPTER XVII.}

Chief Sina-An oath ratified - The bodyguard-Wa-kiboso villages - Extraordinary native engineering operations-A fruitless search for game-A magnificent forest-Ascent of Kilima-njaro -A Kiboso market-place-A false alarm-Fairy forests-The saddle connecting Kibo and Kimawenzi

\section{CHAPTER XVIII.}

Elephants-A novel cure for a headache--A successful snap-shot at a buffalo-Abundance of game on the Abarri liver-Wart-log and eland-Return to Taveta-Revisit Lake Jipć . . . 23y

\section{CHAPTER XIX.}

The Gazella Walleri-Hippopotami-Construction of a raft-Hipposhooting-Alligators-Return to Taveta-Journey to the coast -Ascent of Mount Ndara-Vulturine guinea-fowl-German colonisation-Farewell

List of Game Shot round Kilima-xjaro . . . . . 261

LetTer FRoy Sir R. G. HarTfi . . . . . . . 262

Gaje suen up the Tana River . . . . . . . 283

Aprendix I.-List of Fauva fouxd chiefly in the Platist Round KILIMA-NJaro • . . . . • . . $28_{4}$

List of the Game-birds collicted near lílima-njaro • 29 i Appendix II.-Evgtish-Swahali Vocabulary of Usefui Words 


\section{LIS'T OF ILLUS'T'RATIONS.}

The Gaje Countri . . . . . . . . Frontispiece

The Caravan on the March . . . . . . Page 69

House-buildisg at Taveta . . . . . . " " 86

Native Woyen of Useri . . . . . . . . . . . I

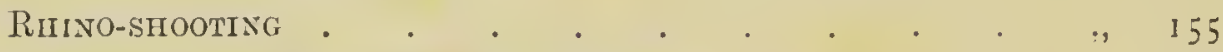

Caravay Crossixg a Native Bridge . . . . : i78

He Felt the Wind of her Body as she passed ovkir

HIS SHOULDER .

AN Uxprotoked Assault . . . . . . . , 202

Evtraxce to Kíboso . . . . . . . . . . 206

A Fairy Forest . . . . . . . . . . . . 215

Moun Kilima-nJaro, $9000 \mathrm{ft}$. . . . . . . . . 220

He caje straight for us with Ears cocked axd

TRUNK ERECT. . . . . . . . . . . 233

Hippo-shooting on LAKe Jilé . . . . . . . . . 249

WEAPONS AND ORNadsexts . . . . . . . . . . 255

Plate I. . . . . . . . . . . . . . 98

Plate II. . . . . . . . . . . . . 106

Plate III. . . . . . . . . . . . . 130

Plate'IV. . . . . . . . . . . . 140

MaP showing the route taken from Mombasa to Kilima-njaro, and the line of march taken, in a series of shooting trips in the adjacent country. 

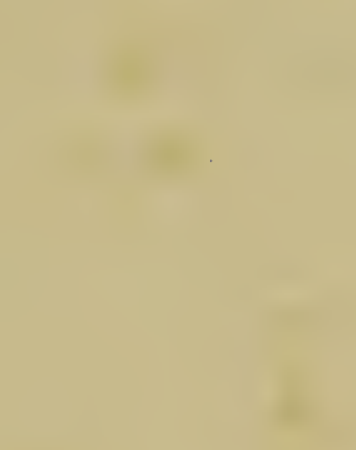

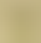




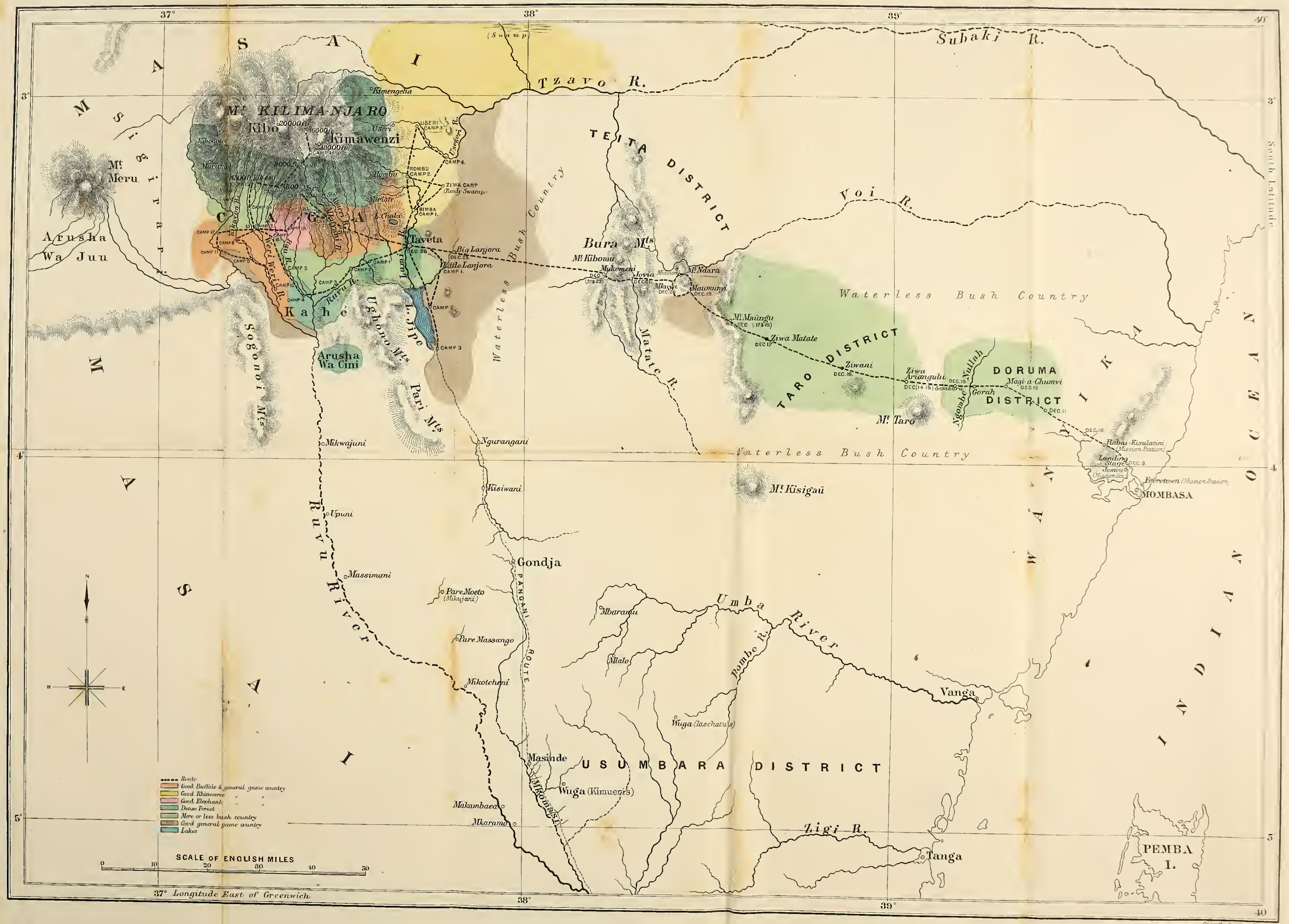




\section{EAST AFRICA AND ITS BIG GAME.}

\section{CHAPTER I.}

The origin and object of the Expedition--Preliminary arrangementsDeparture for Zanzibar-Lamu-Arrival at Zanzibar.

IN the summer of 1886 I decided to pass my winter leave in India, and therefore wrote to my old friend Sir Robert Harvey, who had spent the greater part of the last ten years in shooting over that and other countries, but who was then at home, to enquire whether he intended returning to India in the autumn, as if so we might arrange to travel out together. He replied that he proposed starting for Mombasa in November, and working his way inland until he reached the forest of Taveta and the adjacent virgin hunting grounds in the plains surrounding the base of Mount Kilimanjaro, an isolated and giant mountain situated on the borders of the land of the warlike Masai. IIe added a detailed account of his proposed plans, and excited my imagination with a description of the abundance and variety of game to be met with in those regions.

Owing to the wide-spread terror inspired by the 
Masai, whose constant and sanguinary cattle raids have almost denuded the district for hundreds of miles of its aboriginal inhabitants, this country had not yet been shot orer, and offered to sportsmen, prepared to "rough it a bit," all the attractions of a new field for enterprise; so when my friend finished his letter with a suggestion that I should join him in the expedition, I gladly availed myself of the chance and gave up my original idea without any feeling of regret.

It afterwards transpired that $\mathrm{B}-$ had taken infinite trouble to arrange for a large escort, sufficiently well armed to justify a reasonable prospect of success, and with that object in view had two years previously visited Lamu, Mombasa, and Lanzibar, returning with raluable inland information, in addition to a thorough knowledge of the way the ropes would have to be worked from the starting point.

Our party, in addition to myself, consisted of Harvey, his brother, C. B. Harvey, and II. C. V. Hunter, to whom I refer in the text, for sake of brevity, as B-, C-and $\mathrm{H}$ - We fully realised that a certain amount of risk must be incurred from the probable hostility of the Masai and other native tribes; but this danger we hoped to reduce to a minimum by obtaining a strong and fairly reliable following to be placed under the command of Martin, a Maltese, who had proved his eminent fitness for the post during his term of service with Mr. J. Thomson, the well-known explorer of Masai-land.

Our idea was to proceed to Zanzibar direct, and 
thence, after completing our preparations, to start for the mainland with an escort of some two hundred armed porters, and reach as quickly as possible the forest of Taveta, distant about two hundred and fifty miles from the coast, and within ten miles of the base of Mount Kilima-njaro. Here we proposed establishing a permanent headquarters camp, from which, by a series of shooting trips, we could thoroughly work the surrounding open plains and bush country.

Such was the attractive programme sketched out and based upon the information that $\mathrm{B}$ - had acquired at Zanzibar and Mombasa; to it we all gladly agreed, and I may here say that we were very much indebted to him for his excellent arrangements and for the energy he displayed throughout as leader of the expedition.

On November 5 th B- $\mathrm{B}-\mathrm{H} \longrightarrow$, and myself started by the Indian overland mail en route for Zanzibar, leaving $\mathrm{C}$ — to follow on a month later when his regimental leave commenced. We intended to engage a strong force to be in readiness to escort him up country, and he would be in good time for the real sport, as we expected to be detained for fully three weeks at Zanzibar, completing the necessary arrangements.

A somewhat tedious voyage from Aden was relieved by many amusing anecdotes from Count Teleki, a Hungarian fellow-passenger, proceeding to Zanzibar with the magnificent idea of crossing Africa from ocean to ocean. He was a most agreeable travelling com- 
panion, and though circumstances prevented the full realisation of his hopes, he succeeded in penetrating into the interior for a considerable distance, and, I am glad to hear, has recently returned in safety.

On November 25 th we reached Lamu, and remained for one night to complete a cargo consisting chiefly of irory, gum, copal, fruits, and other native produce.

Lamu is a small Arab fort belonging to the Sultan of Zanzibar, and distant about two hundred and twenty miles north of that island. The town lies some two miles inland, and is approached by a narrow channel separating the island of Lamu from that of Munda. The harbour is dangerous in rough weather on account of its numerous coral reefs and bars, but may be entered with safety when the sea is calm. Shortly after dropping anchor our vessel was boarded by two missionaries, Messrs. Ashe and Wakefield, the former having just effected his escape from Uganda, the scene of the murder of the late Bishop Hannington. They gave us all the latest Zanzibar and mainland news, which included a report about the Masai having raided on the Gallas within fifty miles of Lamu, and information to the effect that elephants and other big game were moring down country on account of the recent rains.

Here we also shipped an agent of the East African Association bound for Zanzibar, who has since had a noteworthy escape from a unique and terrible adventure. While bathing in the shallows off Lamu, he was suddenly attacked and gripped round the waist by a 
shark, but thanks to the immediate rush made by several fellow-bathers on hearing his cry, he escaped with a superficial laceration of the body and a loss of three fingers.

'The following day we left Lamu, and after touching at Mombasa, reached Zanzibar on the morning of November 28th in excellent health and spirits, eager to enter upon the necessary preparations for our inland expedition. 


\section{CHAPTER II.}

Zanzibar-Mr. Holmwood-General Mathews-Route selected-Grave Island-Reception by the Sultan.

ZANZiBar, which is the object of so much political and commercial attention at the present time, contains a fair-sized town of lofty flat-roofed houses, with courtyards in their centres, chiefly built of coral. The narrow tortuous streets point to the buildings having been run up without any planned system or regularity of arrangement, while the sea-board is occupied by a remarkably ugly edifice representing the Sultan's palace, in front of which stands an if possible still more ugly clock tower, now supporting an electric light introduced by the late Sultan after his visit to Europe. 'This erection also serves the useful purpose of a lighthouse. The larger houses are occupied by the well-to-do Arabs and the various consuls, who fly their own flags, and here and there the dazzling whiteness of the buildings is relieved by a poor paln. The British consulate stands alone on a promontory at the south end of the town and is swept by the sea breeze on all sides. Thither we directed our steps on landing and were fortunate enough to find Mr. Holnwwood, the acting Consul General during the absence of Sir John Kirk, at home. Ile received us with much courtesy 
and kindness, and, after requesting the custom-house officials to pass all our luggage free, led the way to a house which had been engaged for us, where all our stores, \&c., had been placed to await our arrival. 'The entrance to our abode was under a guard of the Sultan's soldiers, stationed there by General Mathews' orders, and we went to pay our respects to this excellent officer after arranging for our individual quarters.

'The General gave us a hearty welcome at his snug little residence, furnished with great taste and full of objects of interest,- - specimens of varied eastern arts, swords, spears, daggers and shields of native workmanship, and game trophies of all kinds. Originally in the navy, General Mathews, after his retirement, enlisted in the service of the Sultan of Zanzibar who fully appreciates his great value. He now commands a disciplined army, consisting of 1400 regulars and about 3000 Arab auxiliaries. For the kind and inraluable assistance he gave us in organising our caravan I feel I can never be sufficiently grateful, and I gladly take this opportunity of thanking him again with Mr. Holmwood and other good friends, for their many proofs of hospitality and for the interest and pains they took in starting us fairly on our trip.

The morning after our arrival we were awakened by a tremendous din outside our quarters, caused by about 150 of the men already engaged coming to be enrolled and to receive money for their day's food, which was eight pice (about twopence) per man. The 
siege lasted for two hours, and presented a very picturesque and animated scene. Many recruits were clothed in long snow-white garments, and wore the red fez, and all were shouting, howling, or chattering at the top of their voices, and at the same moment.

It was the first time I had met any Zanzibari porters, and I was much struck at seeing such a fine lot of men; and though we afterwards found they were shocking cowards, they were excellent porters, possessed of great powers of endurance, and capable of carrying their heary loads (65 lbs.) for long distances without suffering much from fatigue.

After purchasing three donkeys, and leaving our head man Martin to make all the arrangements for dividing up our baggage into loads which were not to exceed the regulation $65 \mathrm{lbs}$. each in weight, we walked out to the lawn-tennis ground, distant about one and a half miles from the town. It is approached by a road which is the continuation of the only street in Zanzibar wide enough for carriage traffic; indeed we found that with the exception of the Sultan's "turn-out," and those of a few big traders and merchants, there were no vehicles in the town. 'The lawn-tennis grounds consist of three asphalt courts, charmingly situated and well shaded by magnificent mango trees, of great height, with beautiful dark green foliage. Lawn-tennis is almost the only recreation at Zanzibar, and is much affected by the members of the British consulate, by the officers of the different gun-boats and by some of the local merchants. 
The arrangements for our start for the interior were chiefly entrusted to Martin, who declared our armoury of sixty-five rifles to be insufficient, so we increased it by a few more Snider carbines and about fifty muzzle-loaders. Of course there were endless discussions about the route we should take, though there were only two which we could choose between. One was from Pangani just opposite Zanzibar, and the other from Mombasa. The first was supposed to be too swampy, and the second too dry, so it appeared to be a choice of evils at best. We were, however, assured that at this time of year the Mombasa route would be fairly well watered, and as it offered the attraction of being the shorter we decided to take it.

During our stay at Zanzibar we purchased numerous swords and daggers of beautiful workmanship in silver, gold, and ivory; several were ancient specimens, probably brought over by the Imam of Muscat, when he conquered the island in $I 784$.

The housctops are the favourite living places, with the Zanzibaris, during the intervals of sunshine between the frequent and heavy showers of rain; and here one young black lady used to perform her daily toilet just opposite my window: the chief, and certainly the most laborious, part of the operation consisted in arranging her very thick hair, by the aid of a comb with only two prongs.

We made an early visit one morning, in a boat kindly lent to us by the Sultan, to Grave Island, which is just opposite Zanzibar and so named on 
account of the European cemetery it contains. The were anxious to obtain a specimen of the miniature gazelle, which is said to be peculiar to this group of islands. 'This particular island is one and a half' miles from Zanzibar, and about half a mile in length, and two or three liundred yards in breadth. We found it so thickly overgrown with cacti and thorn bushes, that without dogs and proper beaters our chances of sport were small. Numerous tracks of the gazelle were to be seen, and our boatmen did the best they could to beat for us, but as they were all bare-footed they could not enter far into the bush. After some time B_— was lucky enough to bag a very good specimen, about the size of a hare, with four little feet which could all stand on a penny piece. 'The horns are straight, about two and a half inches in length, and a tall crest of hair grows between them. How the little creatures came to these islands I cannot say; for though found in Zanzibar, and on the other adjacent islands, they are unknown on the mainland.

VTe found some beautiful shells, and were impressed by the artistic effects produced by the action of the waves upon the coral, which was in places hollowed into a series of natural arches. The cacti are of common growth in these latitudes, and contain a milky juice which is a powerful and most inconvenient local irritant if applied to the human skin; hence the caution displayed by our bare-footed boatmen in giving them a wide bertl. 
The following day, at the invitation of the Sultan, we drove out with Mr. Holmwood and Mr. Drummond to Chugnani, to which royal palace we were conveyed in royal carriages driven by rassals in royal livery. The carriages were very shaky old "rattle traps," and the horses anything but high steppers, while the livery consisted of a dirty red coat and a white garment which looked like a cross between a pair of 'Turkish trousers and an English petticoat. We were drawn in state through charming groves of cocoa-nut and mango trees and banana plantations, until we reached the palace which is delightfully situated on a promontory about eight miles south of the town. We were rather surprised to have got there without misadventure, for, though the horses were perfectly steady, the wheels of the carriages seemed disposed to break away. I had always been under the impression that a Sultan's palace was an indescribable blaze of pillars set with sparkling gems of incalculable value, and that if you could pick out a single loose stone and return with it to your native land, a life with such ease and comfort as results from a large rerenue, paid quarterly, would be your just reward. 'The Zanzibar palaces undeceived me, and led me to think that authors, of the most exciting and engrossing books of trarel, were not always the most reliable authorities.

I now believe I can venture to describe the royal palace of Chugnani without fear of being met with the charge of having been carried away by an exotic imagination, the result of basking in oriental magni- 
ficence. 'The building, as I have said, was delightfully situated, but to my unarchitectural eye represented a builder's blot. The ground floor consisted, first of two large unfurnished rooms with floors and ceiling divided by a few trumpery chandeliers, and walls displaying cheap Paris mirrors and a few coloured prints from English Christmas periodicals. Then came something really attractive in the shape of a set of swimming and Turkish baths. A mean flight of wooden stairs led to the first floor, where two rooms, corresponding in size with those below, were adorned by more chandeliers and mirrors and a few old chairs, which were put to shame by a really good carpet. These rooms and a cool balcony, also carpeted, formed the quarters of the Sultan's hundred wives, and were occupied by them whenever their lord and master could tear himself away from the grave affairs of state to spend a happy day at Chugnani. On such occasions all the ladies were packed into carriages at Zanzibar and safely delivered at the country palace, the Sultan bringing up the rear alone in his own carriage like an old ram.

On the balcony orerlooking the sea a most sumptuous breakfast had been prepared for us, with Pira the Sultan's factotum, in attendance. This gentleman performed, among other various duties, those of steward, detective, spy and news-purveyor, and in the latter capacity kept the Sultan well informed of all the local fashionable gossip and scandal. He has, I believe, recently fallen into disgrace, and been 
banished from Zanzibar. Under his superintendence the table had been decorated with tropical flowers, oleanders, hibiscus, marigolds, double jasmine, and crotons of lovely hues; and the royal electro-plate, consisting of odd sets of assorted patterns, had been carefully served out. The feast lasted for an hour and a half and the number of courses seemed endless. We had fish, beef, mutton, chickens, omelettes, and curries, and finished up with jams, mangoes, bananas, and other fruits, all excellent. The crockery matched the electro-plate, as it comprised the cracked remnants of a number of odd sets. We had brought our own wine, for it is contrary to the Sultan's creed to furnish anything but a sickly kind of sherbet to which we had not yet accustomed our digestions. How to kill time after brealifast was a difficult problem, as we had exhausted the attractions of the palace at a single glance and the garden was barren, with the exception of a few oleanders and palm trees. Pira, howerer, pointed out with pride two attractions it possessed of more importance in the Sultan's cyes than mere beds of flowers. The first was a large steam merry-goround, which had unfortunately "stopped short never to go again," as the last time it had been used it had run itself out and steadfastly resisted all the efforts made to wind it up again. The second was a big revolving wheel with cradles in perfect working order, but hardly represented a healthy form of recreation immediately after such a brealifast as we had finished. It was half-past twelve, so some of us decided upon trying 
a nap on the floor as the chairs were all cane-bottomed and high-backed, but within an hour Pira announced that a slight lunch was just served, and this consisted of soup, mutton, pigeons, ducks, curried prawns, iced pudding and iced mangoes. We all ate until we were absolutely stuffed, and had no sooner finished than Pira desired to know at what time we should be prepared for dinner. I thought about that day week at the same hour might do, but the other's made excuses for returning to Zanzibar at once, declaring another such gorge even a week hence might be dangerous.

The drive home was full of such incidents as attend happy holidays even in England. Our weight proved too much for one of the more infirm carriages and a wheel came off which nobody knew how to put on again. This made it worse for the other carriage, which now had to hold five of us in addition to the driver, who, fearing a catastrophe and being anxious to get as near home as he could before it occurred, whipped up his cattle until one became dead beat and had to be rested every half mile. Finally we charged a bullock cart as we entered the narrow street, and this decided us to get through the rest of our journey on foot.

The next day had been fixed for our audience with the Sultan and the presentation of a letter kindly giren us by H.R.H. the Prince of Wales. Accordingly a little after nine, arrayed in black coats and white tronsers, we met at the British consulate, where we found Messis. Holmwood and Drummond arraiting us 
in uniform. We walked to the palace, the narrow streets being lined on either side by the Arab auxiliaries armed with long guns richly inlaid, knives, swords, and powder horns of beautiful workmanship.

'Through this living lane of brilliant and varied colour we marched in single file until we came in sight of the palace. I was astonished to find many of those we passed quite small lads, and was told that each man or youth helping to form this guard represented the head of his family. Facing the palace the regulars under General Mathews had formed line, and looked quite smart in their white tunics and trousers and brown leather belts with shoulder straps and their red and yellow forage caps; while, with their backs to the palace, a small dismounted troop of Indian cavalry were drawn up attended by the Portuguese band. Our appearance was the signal for the latter to strike up the National Anthem, upon which all the troops saluted in orthodox fashion as, hats off, we entered the palace.

'This large and ugly building has a spacious courtyard, from the centre of which a wide double wooden staircase ascends, with as many turns and twists as a Chinese puzzle, to the roof, at least a hundred feet from the ground. At the top of the first flight the Sultan, attended by his principal Arab nobles, came out to meet us and shaking us all warmly by the hand invited us to the audience chamber. Passing through corridors, lined with Persian artillerymen, we followed his Majesty while the band played the National Anthem of Zanzibar, the tune of which reminds one rather of 
some Egyptian melodies, or perhaps more correctly, discords.

The Audience Chamber is a long and narrow room, so long indeed that it might be considered as another corridor, the sides lined with heavy gilt chairs, and the walls decorated by large gilt mirrors. The Sultan took his seat at the further end, and motioned us to the nearest chairs on his right, while the Arab nobles, numbering about forty, seated themselves on either side below us. An interpreter then took his place in front of his Majesty, a strange-looking old gentleman, of a bright yellow complexion with ears stuffed with cotton wool, who wore a pair of blue spectacles, a turban, a long black robe, and a sash. After a moment's pause a fat and stately swell in light brown robes, whom we understood was the master of ceremonies, waddled up the room, followed by servants bearing coffee and the inevitable pink sherbet; of these we had to partake, though fortunately we only had to taste the sherbet, for it is bad manners to take a long drink at a royal reception.

I then stood up and presented the letter of H.R.H. the Prince of Wales, and $\mathrm{B}$ - presented another letter from Sir John Kirk. I accompanied my letter by a short complimentary speech which was transmitted to his Majesty by the interpreter. 'To this the Sultan replied by wishing us every success, adding that, as the Prince of Wales had been so kind to him when he visited England, he would do ererything he could in return for any one bearing his recommendation. 
He then asked how we were going to get to Mombasa, and said he would lend us a small steamer of his own; Mr. Holmwood rather frightened me by replying that we should not require it, as we had already engaged the Henry Wright mission steamer. The Sultan, however, would not hear of our taking any other but his, which was very fortunate, for although the Bishop of Mombasa had promised us the mission steamer, he had just informed us that we could not have it till the following Tuesday or Wednesday as he was most anxious the crew should be back at Mombasa on Sunday to attend Divine service. This would have been inconvenient, for we were most eager to start on Monday, being obliged to give our men two months' advance pay, and every day they were kept idle meant their getting drunk and into mischief.

Thanking the Sultan for his kind offer and for the "delightful day spent at Chugnani!" Mr. Holmwood notified to him that we were quite satisfied with our interview and prepared to depart whenever it was his pleasure to give us permission. This appeared an unusual form of Court etiquette, as it savoured rather more of our dismissing the Sultan than of his dismissing us; however, it was doubtless correct, and the Sultan at once took the hint by rising from his chair, after saying he would give us letters of introduction to all the principal chiefs up country, and conducting us back to the head of the stairs: here we again shook hands all round, while the band struck up our National Anthem and the troops once more presented arms. 
This Sultan, Sayyid Bargash, who I regret to say has since died, was a rither dignified-looking man with a grey beard, and distinctly fat ; this was not surprising, as he was never allowed to take walking exercise, and constantly lived in the society of his hundred wires, who, by the way, were carefully kept out of sight. I belicve the poor man suffered severely from elephantiasis, which probably affected his temper, for though most lind and gracious to us, he bore the reputation of being a bit of a Tartar with his own people. His dress consisted of a turban and simple white robes with a coloured sash, over which he wore a dark Arab coat, while at his side he carried a handsome sword with jewelled hilt. The scene outside the palace could hardly be called grand, but it was gay and animated and rendered picturesque by the many coloured dresses of those who took part in it; altogether the ceremony was interesting as displaying an odd mixture of tawdry pomp, semi-barbaric splendour, and downright shoddiness. 


\section{CHAP'TER III.}

Presentation of letter to the German Society-The General's ruse-The Slave Trade-Mbweni and the Mission station-Missionaries in general and in particular.

Before leaving Zanzibar I called upon Mr. Horneche, the representative of the German East $A$ frican Association, to present a letter from the German Embassy. I had been recommended to do this by Mr. Holmwood. as he expected before our trip was over the Germans would have pushed up country as far as Kilima-njaro, and our presence there might make them suspicious about our real motives.

Mr. Horneche was all civility, and strongly recommended us to take the Pangani route, as they had already established a few stations along it, whereas they as yet had none the other way; and he added, that if we decided upon this road, he would tell all his countrymen to assist us as best they could and to point out the best and safest hunting grounds.

We had been warned to keep clear of the Germans as much as possible, for up to that time they had no firm hold on the natives, and were in fact regarded with much suspicion; had we therefore appeared to be under their protection we should have shared in the sense of disfavour they seemed to have aroused, 
the exact thing we wished to avoid. I therefore told Mr. Horneche that all we required from him was a letter to any of his countrymen we might meet, stating that he knew we were visiting the territory for the sole purpose of sport and in no sense represented emigrants or politicians. This he promised to give me, and as he was clearly overwhelmed with business I at once took my leave. I need not have troubled him at all, as during our whole inland journey we never fell in with a single German.

Shortly before our arrival General Mathews, acting in the interests of the Sultan, had cleverly forestalled an attempt on the part of the Germans to buy up the Caga country, which lies at the S.E. foot of Kilimanjaro. Having got wind of their intention he started off with two hundred native soldiers, and by threats and promises prevailed upon the different tribes to fly the Sultan's red flag. The General completed his journey in twelve days, and accomplished his mission before the arrival of the Germans, who reached the same district in thirty-six days, only to find that the whole country they intended to annex had already loisted the Sultan's colours and acknowledged his suzerainty. The story goes, that on their return they declared they had first bought up all the territory they wanted and that subsequently the Sultan liad forced the inhabitants to lioist his flag, and on this representation, conveyed through the German Consul Roalf, Prince Bismarck thundered forth the most terrific threats, to the efiect that he would despatch a flect to Zanzibar 
and level the whole torn. Before this fleet receired sailing orders, an investigation proved its presence off Zanzibar would be unwarrantable, and the whole affair was settled by the German Consul being requested to return at once to Berlin.*

We were entertained with great cordiality on board H.M.S. Turquoise by Captain Woodward and the rest of the officers, who had their cabins laden with Burmese curiosities, obtained the previous year when they took part in the expedition to Mandalay. The Turquoise, a particularly comfortable ship, is one of two British gumboats now engaged in suppressing the slave trade at this station. A reward is paid for each slave dhow captured, varying according to the measurement of the dhow or the number of slares on board, and it is left to the option of the officers to reckon it at $\delta$ ro per ton or $£ 5$ per slave. 'The system of dhow catching, however, is not regarded in Zanzibar as in any way effectual, and is practically held to do more harm than good, as the real sufferings of the poor slaves occur in their transport from the interior, and once arrived at the coast, their troubles would be over were it not for the presence and activity of the gumboats. I heard a few hideous stories, from the missionaries, of shocking cruelties being practised on the island of Pemba, including that of burying a slave alive, but, in nine cases out of ten, after a slave is purchased he becomes valuable property and is therefore treated with kindness.

* By a treaty made between Germany and Great Britain in rSS6, C̆aga and the whole of Kilima-njaro was admitted to belong to the German E.A. Company. 
In Zanzibar there are of course a great number of slares, though the ruling Sultan pledges himself to do his utmost to stop the trade. With the exception of mission men, nearly three-fourths of the porters we engaged were slares who were permitted to hire themselves out, after contracting privately with their masters to hand over to them one half of whaterer pay they might receive, and though, at first, this seems hard on the workman, it must be borne in mind that the master is always responsible for his being clothed and fed when there may be no work for him to do.

Slavery seems almost inborn in this country, and the natives are so accustomed, and I may almost say suited, to the institution and to no other, that the task of putting it down is, in my opinion, almost impossible. I cannot help thinking our present efforts at suppression represent either too much or too little, and that we should either give up attempting to stop the whole traffic, contenting ourselves with careful supervision and regulation of slare treatment, or that we should make up our minds to spend a few millions and establish a cordon of strong posts in the interior.

'The gunboats, howerer good their efforts, can do nothing torrards suppressing the traffic from the interior to the coast, and the fact of their presence only malies it more difficult for traders to dispose of the slaves in large numbers when they get them to the sea-bord; consequently they now consider them of trifling value, except as porters for carrying down heavy loads of ivory, not caring how many die on the road; indeed it 
is calculated that in the present day not one in twenty ever reaches the coast, a very different average to that which existed when there were open slave markets. Formerly a slave woman who had a child was allowed to carry it, as both she and her child were of some certain value. Now, as her sole value is in proportion to the amount of weight she can carry, if she cannot carry the child as well as the ivory, the former is thrown into the jungle and shares the same fate as those who are too weak to keep up with the caravan (i.e., death by starvation or by wild beasts). If, instead of gunboats, there were open slave markets as before, all these wretched creatures would represent some value, and instead of being used as mere transport for irory, and flogged till the last gasp, they would be treated with some consideration for their owner's sake.*

From what I know of these natives, I believe slavery properly supervised would be no hardship. They are childlike and of a singularly low order of intelligence, and it has yet to be demonstrated that they are capable of being improved up to a point of understanding needful to fit them for higher callings. So-called civilisation by conversion will not do it, as under such conditions the low class native simply deteriorates into the utter blackguard. I have no wish to advocate slavery as a principle, and would gladly subscribe my'

* Though now, as in former days, a male slave is valued at thirty-five dollars, and a tolerable-looking fenale slave at seventy to a lundred dollars, the fact of private auctions replacing public ones, and the prolibition of the sale of "green slaves" (those just scut to the coast) at any auction, makes the contraband trade difficult and risky. 
mite to see it stamped out root and branch, but we must begin at the root, and until some movement to this end is set on foot, harrying the slave dhows with a few gunboats only aggravates the misery of the poor wretches we are all endeavouring to serre.

The Saturday after our arrival was quite a gala day, as we had to take the names and hand over the two months' advance pay to the one hundred and fifty-fire men we had already engaged, a matter of nearly four hours' hard work amidst indescribable din and confusion. General Matherws kindly helped us with the names, which were often very curious. We had one porter called Open Grave, another Kiboko or Hippopotamus, a third Elephant's 'Tooth, and other's equally uncommon. Many of these big fellows were led up by tiny Arab boys who claimed them as slaves, and who promptly annexed the half of their wages as soon as they were paid. The pay of the men was five dollars, or nearly eleven rupees a month, though some of the head men had more than twice that amount, and of course the moment the money was paid all rushed off to spend as much of it as they could in a tremendous drink.

The following day we drove out in one of the Sultan's carriages to Mbweni, where Sir John Kirk has his country villa, to which Mr. Holmwood had invited us. It is a charming little house, built on a small promontory well shaded by large palm trees and mangoes, and surrounded by an exquisite garden, in fact, the exact antithesis of the Sultan's country palace of Chugnani. 
We greatly regretted the absence of its kind and most distinguished owner, who had done so much to further the object of our expedition. In all quarters we heard him spoken of with admiration and even affection, and to his personality and power of administration the British prestige in this part of East Africa is entirely due. Sir John Kirk is a great admirer of beautiful flowers and shrubs, and we noticed india-rubber plants, mahogany trees, tropical pines, hibiscus, oleanders, frangipani, pine apples, dwarf palms, clove bushes, and many others ; they had been imported from all parts of the world, including Kew Gardens.

After breakfasting under a splendid mango, we spent the day in wandering about the garden, taking photographs, and playing lawn-tennis on a capital asphalt court, and in the evening strolled up to the Mission station.

'This colony is arranged in three sections, the girls', the bachelor's', and the married quarter's. 'The latter consist of neat little huts, with a small garden plot attached to each. Bishop Steere, I am told, did much for this Mission during his tenure of office, and introduced the hand-saw and a traction engine, and taught the people how to niake lime from the coral: he also got a windmill as a water-drawer, but unfortunately the sails never arrived from England, so it merely represents a memorial. With his death all practical enterprise died, and now, instead of the girls being taught to cook and the mon to work, the observance of ritualistic exercises scems the chief occupation of the existing 
missionaries in Zanzibar. On this account, I was told, the men seek their wives among the Mohammedan women, upon whose conversion, by the way, a large amount of money has been fruitlessly expended by the various missions. I have no doubt that Bishop Parker has altered all this now, and is endeavouring to do good among the veritable heathen on the mainland, instead of trying to induce those who have a religion, which they understand and which suits them, to exchange it for one which does not. Although there are some excellent men among these missionaries, few are well educated, the majority having been manufactured out of traders, clerks, or mechanics. The process is not a difficult one: a man, thinking he can improve his position by missionary work, has only to go to a school for a year or two and learn a certain amount of medicine and carpentering, flavoured with a little theology, and he is turned out a full-blown missionary and orthodox deacon by the local bishop. This, I am assured, is the system in vogue, by those professing to be well informed.

On our return to prepare for dinner, we found one of the windows of the house occupied by a swarm of bees, and as we did not interrupt them by making any very close inspection, they showed no disposition to interfere with us. Te had an excellent repast, and, after drinking the healths of our present and our absent host, returned to 'Zanzibar, and got to bed early in anticipation of our intended start on the following morning. 


\section{CHAP'TER IV.}

Departure from Zanzibar-Arrival at Mombasa-The Governor-Freretown Mission Station-Final arrangements for the Interior-MIr. Shaw's objections.

ON Monday at 5 A.M. we began to send our loads on board the Sultan's steamer Star, and having some final commissions to arrange, I left my friends, promising to be on board at noon. On my arrival I found the decks so crammed with our men that I could hardly move, but there were no signs of $\mathrm{H}-$ and $\mathrm{B}$ - nor of our servants and personal baggage. The Captain, a dried-up old mummy of an Arab, began to be impatient, as he had becn ordered by the Sultan to weigh anchor between 1 and 2 P.M., the wise men having explained that the omens were good and foretold a prosperous voyage if we started at that time. Shortly before the auspicious hour of 2 P.M., the luggage arrived, and, tired of waiting, I went ashore to hunt up the truants. I found them busily engaged over an excellent luncheon with Drummond, and oblivious of everything except the immediate calls of hunger. It transpired they had received a message to the effect that the Star would not sail before 3 P.M., but had quite forgotten to let me know. Drummond seemed determined not to let us go before we had 
emptied his cellar, but we at last succeeded in making a move, and, accompanied by General Mathews, reported ourselves as "come aboard." Here we took leave of that excellent man and warmest of friends, to whose name I can never refer without feelings of gratitude and sincere esteem. It must have been a sad day for his shipmates when he left the nary and a real loss to the service itself.

While Zanzibar was fading in the distance we rigged up a canvas screen to separate us from our live cargo, who were only just recovering from their pay day carouse, and though packed like sardines, found room to quarrel, gamble, sing, and eat in turns. Beyond the fact that this voyage to Mombasa ras nearly as uncomfortable as a voyage in fair weather could be, it presented nothing worthy of record, unless it were that we had a most excellent goat for dinner, stuffed, after Arab fashion, with raisins, rice and herbs, the thoughtful parting gift of the General, who knew we should have considerable difficulty in attempting to cook a meal on board.

We made Mombasa on the morning of Dec. 7 th, at Io A.M., and immediately proceeded to interview the Lewati (Governor), who had been warned by the Bishop that we should require a hundred men, in addition to those we had, to assist in carrying our loads to Taveta. 'This Governor, a wizened-up little man, singularly like a magnified edition of the organ grinder's monkey, received us with much hand-shaking and many jambos (How are you?), and led us into a kind of cell, where 
we sat down, surrounded by the principal Arabs of the town, and became special objects of interest to a crowd of loafers now peering through the window gratings. 'These latter, from the eager way in which they endeavoured to catch every syllable uttered, were evidently the "local reporters," who, no doubt, would spread the result of our audience throughout the town directly the interview was over.

After the inevitable coffee and sherbet, we proceeded to business, and were disappointed to learn the Governor had no men ready, the excuse being that the "order was not accompanied by a remittance." In reality, I think he was afraid that any Mombasa contingent would desert us, and that he would be subsequently called to account by us, and by the Sultan, for not having supplied more reliable material. He arranged, however, at once, to do his best, and set a few Arabs at work to collect the necessary number, which, of course, entailed delay. After salaaming the Governor, we paid a visit to Mr. Shaw, the missionary of Freretown, who lives in a little white house surrounded by palm trees situated at the further end of Mombasa harbour. He politely invited us to remain to luncheon, and while this was being prepared we called upou the Bishop, who was just starting for Rabai, another mission station situated seventeen miles further up the creek. He received us very lindly, and invited us to occupy the Vice-Consul's house during our stay at Mombasa.

I3- and I then went for a little stroll through 
Freretown, where we found evidence of useful civilisation in the form of neat huts, a church, a school, and well-kept paths and roads, and returned to Mr. Shaw's house with a favourable impression of this Mission station. Mr. Shaw had lately paid a visit to Mandara, the chief of the Moči, * a rather important tribe occupying the Kilima-njaro slopes. On the way he had shot two rhinoceros and a giraffe, and he showed us a photograph of the latter, taken while it lay wounded on the ground: the only other instance I know of a wild giraffe being photographed occurred in the Kalahari desert, when the well-known gymnast, Lulu, operated very successfully on a beast driven to bay by Mr. Farini. Mr. Shaw had not fallen in with any war parties of the Masai, and did not think it probable that we should do so on our way up, as the present month was not their favourite raiding season.

After luncheon we adjourned to the Vice-Consul's house, where our baggage had preceded us. This building stands on a small cliff, in the middle of Mombasa, and is approached by a steep underground staircase excavated in the rock. It is very old and bears an ancient Portuguese inscription, and its associations are interesting, as it has twice been occupied by officials of the English Government, and has often given shelter to celebrated explorers while they were making arrangements for a start into the interior. Mombasa is a pretty old town, and has known prosperous and active times, which, under the gorerning 
auspices of the British Imperial East African Company, will, it is to be hoped, again return. Five hundred years ago it was the main outlet for all commerce from the interior, and since then it has sustained the assaults of English, Portuguese, Arab, and other foreigners. An excellent description of its history may be found in Mr. Thomson's book, "Through Masai-land." The town is situated on an island, of which only a small portion is cultivated, the rest being covered with dense bush. A great deal of its recent trade has been diverted by the Pagani route, which, though longer, is easier and far better supplied with water.

In the erening we sat in council discussing the forward move. Martin was all for our starting at once to Taveta and taking with us as many loads as we could carry, allowing him then to return for the remainder, as he was afraid that if we stayed long at Mombasa our Zanzibaris would desert. We decided, however, to arrait the turn of erents for at least a day or two, and those of the next day seemed to justify our decision, as about thirty men came in by twos and threes and offered their services, which were formally accepted.

During the afternoon, $\mathrm{B}$ - paid a visit to the Governor, carrying with him a present of a revolver and an infantry Colonel's sword, for we were now in the land of those who considered it more blessed to receive than to give, and every one expected something. $\mathrm{B}$ - was received by the Governor in a large 
shed, in the presence of what seemed the whole Arab population; the gifts had to be presented with the utmost formality, and after receiving them the Gorernor expressed his intention of returning our visit on the following day.

The water at Mombasa was rery bad, and, being unable to get at our filters, we had to put up with cocoa-nut water, which, though not unpleasant, fails to quench the thirst satisfactorily; we also tried some strange stuff called "toddy," made from the juice of the cocoa-nut palm trunk left to ferment. It is sweet and intoxicating, and only to be appreciated by an "acquired taste."

The natives told us that the lious in the neighbourhood were numerous and bold, and that during the last three days they had carried off two women. I was anxious to set a bait and sit up for them during the night, but $\mathrm{B}$ - said it was a sure way to get fever, and that if the lions were genuine man-eaters they would never go for the bullock, so I gave up the idea.

The next day the Governor liept his word and returned our visit early in the morning, accompanied by eighteen other Arabs, among whom we divided the seven chairs, which were all we had. IVe were also placed in a slight difficulty by having no coffeepot and only four coffee cups, but orercame it by making an old tea-pot do deputy, and serving on guests with their refreshment in small detachments. $A$ raried group they were, of all shapes and sizes, clad 
in garments of every hue, black, red, brown, and yellow predominating, and after remaining with us for a quarter of an hour they departed with many jambos and hand-shakings.

The new porters did not come in for enrolment as freely to-day as yesterday, but having made our complement up to a hundred and ninety-one, we decided to start the next day for Rabai, in the hopes of being able to get some more volunteers there. The afternoon brought us a surprise in the form of a most indignant letter from Mr. Shaw, who complained that we had not acted fairly by him in engaging men from his mission without his sanction, particularly as he had told us he did not approve of their mixing with our Zanzibaris. It struck me, from this letter, that the poor mission men, who are all freed slaves, had only left one form of servitude to embark in another, and that it was rather hard they should be prevented from earning their living by active and honest work, because it entailed their being temporarily removed from the immediate influence of the missionaries. As a matter of fact, we were quite unaware we had enrolled any mission men at all, having made no enquiries about the particular creed of those who offered their services. However, we threw what oil we could on the troubled waters by sending Mr. Shaw a letter full of apologies and explanation.

The Governor, during our stay, was kind enough to send us milk twice a day, a very acceptable form of present, for that commodity is uncommonly scarce 
at Mombasa. Our next manœurre was the engagement of four dhows to convey us and our loads to Rabai, and after this, with the exception of about sixty more carriers, whom we expected to get without much trouble, our final arrangements for starting into the interior were as complete as we could manage to make them. 


\section{CHAPTER V.}

Voyage in the dhow-The first camp--Rabai-Effect of Masai raidingThe complete caravan-Mission men against Zanzibaris-Deserters.

ON Friday, December Ioth, we made our start for the interior: this was thirty-five days after leaving England, and considering all things no very long period, as our preparations were made in a country where to-day means to-morrow and to-morrow means the week after next. Our despatch was mainly due to $\mathrm{B}-$, who had visited Zanzibar two years previously to find out what we should require, also to Martin's energy and to General Matherrs' kind assistance; under ordinary conditions I believe we should have fared no better than Count Teleki, and kicked our heels at Zanzibar for at least another month. We started the three dhows containing the porters and their loads, and at 8.30 A.M. followed in the fourth with our personal servants, stopping for a short time at Freretown to bid Mr. Shaw adieu. He had quite recovered from his huff, and kindly agreed to send our mail up country once a month. A strong tide, rumning in and out of the creek, was now in our favour, and we sailed merrily along, though the ship was sufficiently leaky to require constant baling. 'The shores of the creek are fringed by swamp corered with mangroves, curious bushes 
which spring straight from the swamp, and throw out roots in all directions until they form an impenetrable maze of net-work. 'The country is hilly and well wooded, especially near Jomvu, a small mission station within eleven miles of Mombasa, where we disembarked to call on Mr. Wakefield, a missionary we had previously met, but who was unfortunately from lome.

We arrived at the landing-stage (for such is it called) about I 2.3O P.M. We were fourteen miles from Mombasa, and a walk of half a mile brouglit us to our first camp in East Africa, which presented a very active appearance. Our tents were already pitched, and the loads stowed away in huts built by the missionaries for that purpose : the rifles and pouch-belts were just being served out to some of the men, while others were receiving their daily portion of rice, and the remainder engaged in completing a circle of grass shelters for themselves around our tents. The afternoon was occupied by the men carrying extra loads up to Rabai, about three miles off, where we hoped to obtain the additional number of porter's required.

'The next morning we made an early march, and reached Rabai, in an hour and a half, after a stiff climb up a narrow pass bordered on either side by thick coarse grass, the country here being hilly and well wooded with clumps of palms and thorn bushes. Rabai is a large mission station, N.N.W. of Mombasa, 750 feet above the sea level, and consisting of many huts dotted over an extensive area of cultivated ground. A large church was in process of erection, and near it 
the usual big bell which summoned the people to service or to school was conspicuous. Freed slaves undergo the difficulties of elementary conversion and education at Freretown, before being passed on to Rabai, where they receive a plot of ground to cultivate, the produce of which finds a ready market among the passing caravans: they do not grow rapidly rich, but all who are willing to work can, in this way, earn a modest livelihood.

Some of the questions put to me by a mission boy who could speak a little English were amusing. He began by asking-

"Tou missionary?"

To which I replied, "No."

"You trader?"

"No."

"Then what for you come here?"

"To shoot animals."

He looked puzzled for a moment or tro and then said-

"What for good?"

I tried my best to explain we wanted their heads as trophies, but he only shook his own head sorrowfully, as though it was clear we were all perfectly mad.

At Rabai we occupied the house of Mr. Binns, the resident missionary, then absent on a visiting tour. We expected to be detained a day or two as twenty of our men were missing, but fortunately they turned up in the course of the afternoon, with the excuse of haring lost their way, though I believe they had pur- 
posely kept out of it to shirk carrying their loads. With the help of Mr. Jones, a black missionary most obliging and active, we were enabled to make up our number of carricrs to 250 ; so after 13 - had paid the advance to the fresh hands, they were started off, under the command of Martin, to a place about seren miles due west of Rabai, where we joined them when the moon had risen. There was a fair stream near this camping ground once the site of a peaceful village, but the formidable Masai had killed all its inhabitants, and by their constant raiding depopulated the whole neighbourhood. The country here is rendered unhealthy by heavy dews which fall during the night, also from the miasma which rises from the rank regetation in the swamps.

As we had now completed our outfit and forces, a short review of our complete caravan may prove interesting.

Martin the leader and factotum was a Maltese, once a sailor and afterwards attached to the Freretown mission station: later on he acted as caravan leader to 'Thomson during his journey through Masai-land, and it was owing to the excellent reputation he then acquired that we made every endeavour to obtain his services; these we found invaluable on account of his tribal knowledge, experience, and tact in handling. our whole caravan. IVilling, energetic, and handy in all things, though unable to read or write, he represented a treasure of great worth. Next came Cačeche, a wily old nigger with a foxy expression, who 
had been with Stanley on the Congo and learnt too much! I should certainly never employ him again, as I believe he was at the bottom of all the difficulties which arose between us and our men. Then followed Omari, a native of a very different type, who had been a sergeant in the Sultan's army, a very good and useful fellow who could read and write Arabic. His chief duties were to keep the muster roll, portion out the food, regulate the pay, and march in front of the caravan with our flag. After him were Bohete and Suleiman, two very good head men, Preston, Jumma-Orioladi, and Kasibete, who all spoke English. Then came about sixteen lesser lights, who carried no loads, unless some of the porters broke down, but whose duties were to keep the carriers in order on the march and do the principal part of the tent-pitching, building, and hedging, when we came to camp. They were armed with long or short sniders with bayonets, and we had, in addition, about one hundred and thirty mixed Zanzibaris, who carried short sniders and old muzzle-loaders. Many of these were really well-built men, with great powers of endurance, and capable of carrying heavy loads for long distances on short allowances of food and drink; their full rations only consisted of one pound of rice, indian corn, or bananas. The last of the cararan consisted of one hundred and twenty mission men, a class very difficult to manage. 'Their disposition and physique may have been injured by their religious training, for the majority were idle, drunken, and untrustworthy, and never attempted to 
carry a load exceeding 50 lbs., the mission stations' regulation allowance, whereas the others would willingly carry one of 65 lbs. without a murmur. We were unanimous in our decision to dismiss these mission men as soon as we reached 'laveta, our proposed headquarters. Three of our personal attendants were Indians. John the headman was told off to $\mathrm{H}$., and looked after the other two; Boy was B.'s servant; and the third, who was a native of Goa, acted as cook. His chief faults consisted in making a point of getting drunk or catching fever whenever he got the chance, and now and again he would manage to pull off the double erent. My man was a strange indiridual, named Anole, a native of the Seychelle Islands, a buck nigger and a first-class rascal. He could speak a little Swahili and string together a few words in French; his accomplishments were dancing and fighting (le boxe, as he called it), neither of which were of the least use to me.

Our loads comprised cotton cloth (American), iron and copper wire, trade powder and beads of all sorts to suit the different native tastes, always capricious, and a few packages of double-barrelled guns, revolvers, musical boxes, clocks and "startling novelties," intended for special presents to the chiefs. Martin had fire men told off to carry his tent and baggage, and we had a number more for our personal equipment and ammunition. 'The donkeys, who helped to carry the tents, required three other donkeys, in the shape of mission buys, to look after them. 
Our battery consisted of an 8 -bore double-barrelled and rifled, a $577^{\circ}$ express and a $450^{\circ}$ express apiece, in addition to shot guns. The 8 -bore fires eight and ten drachms of powder and a semi-conical solid bullet hardened by a mixture of tin and lead, which I found more effective than any other. The $577^{\circ}$ fires nearly seven drachms of powder, and the $450^{\circ}$ nearly six, and we rised conical hardened bullets with both, in preference to any others.

Our dress consisted of Kharki Norfolk jackets with spinal paddings, flannel shirt, cummerbund, knickerbockers, strong shooting boots and pith helmets. We had Indian double tents, of different sizes, for ourselves and a single one for the servants, and a reasonable amount of medical comforts in the form of champagne, claret, port, brandy, whisky, and special articles of diet. I have entered into this full detail of our caravan equipment, as it should be of some use to others who may feel disposed to start on a sporting trip over the same country; and though they could not now expect to find the hunting grounds in a virgin state, they are still capable of yielding fair sport to hard-rorking sportsmen.

A single description of our camping arrangements will be sufficient, as they wcre all very much alike, with the exception that, when we reached a game country, we made a hedge of thorns (boma) every night, as a protection against wild-beasts and possible surprises from hostile natives. Directly the ground for a camp was selected, an imposing centre point was made by 
the porters piling up all the loads we were in no immediate want of, and finally covering the whole with tarpaulin sheets. Near this monument, and in the most convenient spot, our three tents were pitched, the big one for ourselves and the two others for Martin and the servants; we had a fourth, but we did not use it, during daily marches, on account of the length of time occupied in morning packing. 'Tents are an absolute necessity in this part of Africa, if the certainty of getting bad fever is to be avoided.

Having finished this work, the men had to choose the spots for their own messes, consisting usually of six or seven persons, and these little camping grounds always formed a complete circle round us. Here the porters lighted their fires and cooked their food, and, when we remained for any length of time in one place, erected sleeping shelters coustructed with boughs and grass. At the outset they were a very cheery lot, and just like a troop of children, laughing, singing, and shouting half through the night. They were by no means difficult to manage, if one took the trouble to understand their little ways, and they were never difficult to arouse in the morning, however late their night amusements had been carried on. 'The Soudanese, with whom I had much to do during the Nile Expedition in ' $s_{4}$, were the exact opposite, and really had to be whipped up every morning, for they entertain an absolute horror of "turning out" before the sun has risen. A reason may probably be found in the fact that the early mornings, in the Soudan, were bitterly cold, whereas in East Africa 
the thermometer never registered below $70^{\circ}$ unless we were in the mountains. The rifles pleased our men immensely, and made them feel quite proud of themselves; they played with them like children with new toys, and as there were no less than a hundred and thirty of these weapons, there were just so many chances of a stray bullet finding an unintended human billet; but we managed to escape any such catastrophe, and the only thing that ever got hit, by an accident, was our big tent.

Up to the present we had only lost seven men by desertion, a singularly small arerage, as, whenever cararans start for the interior, there are always a number of rascals who readily enlist in order to obtain the two months' advance pay, and have every intention of slipping back to the coast on the first opportunity. For this reason one has to be very wide awake during the earlier marches, and to look sharply after the muster roll. Later on there is less fear of desertion, as, once well away from the coast, the majority are a great deal too timid to venture upon returning to it alone. 'The loss of these seven men did not cause us much inconvenience, for, thanks to $\mathrm{Mr}$. Jones, we were able to replace them. One intending deserter, who had pawned his rifle at Rabai, we caught and immediately handcuffed as a wholesome warning to all the rest.

The march to Taveta I propose describing by giving extracts from my journal, which I hope may prove less wearisome to the reader than the actual journey did to us. 


\section{CHAPTER TI.}

The Wa-nyika-A lioness-Sable antelope--The Doruma-Taro-A dry camp-A forced march in search of water-Maungı-Mr. Wray--The Ndara range- The Wa-teita.

December I 2 th. - No rery early start was made this morning, the men having had a hardish time of it yesterday, so we served out their food and gave them time to cook it. Only three men deserted during the night. After breakfast we started, at about $S$ A.Mr, carrying our guns in the hopes of falling in with guinea-fowl or partridges, but only saw numbers of pretty little birds with brilliant plumage. 'The country was undulating, and the scenery distinctly monotonous : the road fairly good, though narrow, compelled us to walk in single file, and the grass on either side was scanty, as the natives fire it twice a year. Many wild flowers and shrubs attracted the eye, but most of the former had little or no smell; I noticed particularly convolvuli of all shades and colour, wild jasmin, cactus, mimosa bushes and numerous evergreens-like those I have seen growing in hothouses at home. At times we saw some beautiful locusts of a pink colour, which, when disturbed, flew, or rather jumped, about twenty yards. The whole country, through which we were passing, becomes perfectly parched in the dry season, 
when no rain falls; but at this time of the year there is generally plenty of water, though of indifferent quality, and there are several small marshes on either side of the route. The inhabitants of these, chiefly represented by frogs, toads, grasshoppers, and thousands of water insects, render night hideous with the deafening noise they make.

A march of fourteen miles brought us to Magi-achumvi (salt water) near a moderate and brackish stream, and on arriving at the camping ground only a few natives came to look at us. They were naked, with the exception of a dirty piece of cloth round the loins, and loaded with brass chains round their necks, and coils of copper and iron wire encircling their arms from the wrist to half way up to the elbows; they also wore rings of a white metal in their ears, and others, of brass, on their thumbs and fingers; the hair was shaved off round the base of the skull, leaving a tuft which they worked with grease and clay into tassels. All carried bows and quivers full of poisoned arrows, in addition to calabashes filled with water or with grain. 'These people, who are the only inhabitants of this territory, are called Wanyilia (people of the wilderness) : they are very ugly, dirty, and of a low type: they were not at all obtrusive, but, sitting down in a row some distance from us, seemed much terrified when our donkeys appeared, as though they had never seen any animals of the sort before.

In the afternoon I went out to shoot for the pot, as we were short of meat; I heard some partridges calling 
close by, but only managed to get one; in the course of my stroll I came across the fresh form of a large animal, and after following its tracks in the long grass, for about 300 yards, got a splendid view of a fine lioness about eighty yards off. I had only a shot gun with me, so I turned round and seized the snider my native was carrying, but unfortunately it was unloaded, and before I could push in a cartridge, the lioness had moved slowly into some thick bush close by and was lost. As it is only by the rarest accident that lions are met with in the day time, it was most unlucky to have missed this chance of a shot.

Three men, who had tried to desert on the march this morning, were caught by the askari and made to walk into camp stark naked; on arriving they were perched on the top of our pile of baggage and all the men collected to jeer and hoot at them, after which they were handcuffed for the night. The elevation of our camp was about 900 feet and the heat liad been great during the march, indeed it would have been almost insufferable but for a nice westerly breeze. All the men were a bit soft, and therefore travelled very slowly.

December I 3 th. - Starting to-day in good time, at 5 A.M., we were soon making a gradual descent of some 300 feet, after which the track led us through a perfectly level country alternating in bush and open plain. Here I had a long shot at a sable antelope; there were five of them altogether, but so wild that I could not get nearer than 250 yards, and apparently 
my shot did them no harm, as they all scampered off through some bush into a plain half a mile beyond. I followed them a long distance, but as they were so difficult to approach I gave them up, though, had I known they were the only specimens of the kind I was destined to come across during my wanderings, I would have followed them much farther. I knocked down a partridge and a quail, and $\mathrm{B}$ - saw several guinea-fowl, though he did not bring any back. We passed through some once cultivated ground, long deserted and now overgrown, but it was weary work pushing our way through the thick grass and rank vegetation, with which the track was quite obscured, during a heat that was most oppressive. After a fourteen miles march Samburu was reached, where there is a fair supply of rain water filling curious excavations in the black rocks: many of these holes were quite round and of considerable depth, and must have been the result of a natural and chemical process assisted by the hands of natives, who, I imagine, have at some time or other endearoured to enlarge them.

Soon after pitching our camp the natives came down in considerable numbers from two adjoining villages to sell food, and we were able to obtain pineapples, kundi, (a small kind of bean), in addition to fowls and eggs, all of which came in most useful. 'The name of these people, who are apparently only just superior to the Wanyika, is Doruma. They wore the same class of ornaments, but the women affected a dirty sort of linen 
kilt, and carried their children, in a cloth, slung orer their backs; they dare not attempt to keep many cattle in consequence of the yearly raids of the Masai. In the evening, at a Durbah of the elders, Martin with all due ceremony translated the Sultan's letter, but they only replied, "What was the use of a letter without any present?" however we did not take the hint, broad as it was, for Martin said it was quite unnecessary.

December I 4 th. - A day of rest; a supply of three days' food for the porters being required, which was obtained very cheaply here, only costing us twelve shillings per day to supply two hundred and fifty men. We took the opportunity of photographing some groups of the natives as they did not seem to object, and we also photographed our head men and askaris. $\mathrm{H}$ —_ shot four doves, one quail and a landrail. In the afternoon I held a levee of natives, and showed them the pictures in Mr. Thomson's book, "Through Masai Land," and in Mr. Selous' book, "A Hunter's Wanderings in South Africa," with which they were delighted; but I had to give it up after a short time, as the odour of unwashed savages became rather too strong. Some of our men got up a dance in the evening, each carrying the branch of a tree; the music consisted of a rude drum and reed pipes, accompanied by the howls of the dancers.

December I 5 th. - We started at 5.45 A.Mr., and had a monotonous march of fourteen miles through a level country covered with dense bush; the camp was pitched at Ariangulu, in the 'Taro district, close to a 
small range of hills south-west of our camp, the highest of these being about 1600 feet; on the march we obtained plenty of water, and the dew from the bushes wetted us to the skin in the early morning. As we proceeded, the colour of the soil changed from sandy brown to a bright red, most dazzling and trying to the eyes. Nothing was seen on the march except monkeys, but some natives who risited our camp said we were likely to come across giraffe, hartebeest, and other animals soon, as it had been raining heavily up country and the game was moving down.

The elevation of our camp was about r roo feet, and the weather being showery, our men encircled us with grass huts for the night. Three porters tried to rum away, but two were caught and handcuffed; I asked Martin why he did not flog runaways, but he said flogging had no effect, and the best plan was to put them on half rations and give them extra heary loads to carry. Though several of the men had ferer to-day, on the whole they marched better, and were evidently getting gradually harder.

December I6th, I 7 th. - 5.30 A.M. saw us again on the move, the path leading through the same sort of country as yesterday; some buffalo and antelope tracks were discovered, and B-shot a small gazelle about the size of a hare (Neotragus Kirkii); this we coolied for dinner, and found the meat excellent. After a march of about fifteen miles we came to Ziwani (by the water hole), where, to our great disappointment, only enough water was found to fill two or three 
buckets; some bushmen came up and offered to show us "water holes known only to themselves," if we would give them eight hands of cloth. On our agreeing to this, one of the headmen innocently handed over the cloth, and then, followed by one or two askaris. started off with the guides to find the water, but he returned shortly with a long face and the sad news that the bushmen had bolted as soon as they had got a little way into the bush.

When Martin arrived, with the tail of the caravan, we held a consultation, and decided that the best thing to do would be to wait till the moon was up, and then make it a case of sauve qui peut, and let every man "leg" it as quickly as he could throughout the night to Ziwa Matate, the next watering-place, about twentyfour miles farther on.

When all the loads had come in, a terrible discorery was made; the one containing all our boots and 2000 rupees, which Martin was taking up to Mandara, chief of Moči, in payment for irory sent by him down to the coast, was missing. Though it seemed but a forlorn hope, a reliable askari, called Chandi, and three men were despatched with orders to go after the runaway right back to Mombasa if necessary.

Half an hour after midnight we started with our personal servants and one man as guide, and marched straight on throughout the night till 7.5 A.M., only stopping a few minutes to rest on the way. My man Anole led the ran with a lamp, and it was impossible not to laugh at the curious figure he cut, with nothing on 
but a little white chemise, a roll of cloth round his waist, and a turban on his head, with my spare helmet perched on the top. He carried my gun, rifle, cartridge-bag, field-glasses, and other odds and ends, and I must admit he prored a capital walker, and by a comical wriggling action managed to escape getting scratched by the thorns.

At about 6 A.M. the features of the bush changed slightly, and the soil became of a more vivid red colour. I noticed a new kind of thorn with very dark green leaves resembling those of the laburnum. We here came upon a number of animal tracks, and Bluckily shot another small gazelle, otherwise we should have had nothing to eat for breakfast. At 7.45 we arrived at the next watering-place, but only to find enough muddy fluid to fill a bucket or two; so after a rest of one and a half hours, we pushed on to Maungu, about thirteen miles farther. This was by far the worst part of the whole journey, as it was getting intensely hot, and the path was steep and difficult to find in its windings in the dense bush. At last Maungu was reached, after a march of about fifty-three miles in thirty hours, the last thirty-eight miles being accomplished in twelve hours, including the halt for breakfast.

On arriving at the camping-ground, it was necessary to send our guide to the top of the hill for water, a matter of half-an-hour's steep climb. The first men with loads came in about 2 P.M., and, wonderful to relate, nearly eighty arrived in the course of the day; the remainder, unable to find the track owing to dark- 
ness intervening, had to sleep on the road. We sent off as many men as we could induce to go, after they had rested, to carry water to Martin and the stragglers, who must have been much in need of it; and I am glad to say we secured a sufficient number of recruits without having to resort to blows, as no one could have found the heart to lick the poor fellows, eren if they had refused, after their long march. It will always be a marvel to me how any men could do such a tramp with so little water and no food, carrying the loads they did.

We had our first regular meal of the day at 6 P.M., consisting only of roast gazelle and chupatees, but luckily we found a case of champagne had arrived, and this we had open in no time. What a pick-me-up it was! I am sure none of us had ever appreciated a drink so much before. Fortunately a small tent had also been brought in, for, to make things thoroughly pleasant, shortly after our arrival a heary downpour of rain set in, lasting for two hours. We were in the hopes that Martin would benefit by this, but we afterwards learned that no rain had fallen where he was, though the distance between us was only ten miles. These showers appeared to be very local, and rain fell but rarely between Maungu and Ziwani. The former place is about half-way to Taveta, so we had now accomplished some hundred and twenty miles since leaving Mombasa.

December isth.- We sent up a fatigue party for water the first thing in the morning, and II_— with 
twenty rolunteers went off to the relief of Martin. In the meantime those who had slept on the road kept dropping in, and eventually the last stragglers turned up with Martin about Io A.M. On his arrival we learned there were only six deserters, a very small number considering the terrible march undertaken by those who were loyal. A day's rest at Maūngu was decided upon, the men being naturally exhausted, and many of them having their shoulders perfectly raw from carrying the loads.

Our present situation was about 2 roo feet above the sea, and more than half way up the hill range, now reached, which consisted of three or four abrupt elevations. The view from the one we had selected for a camping-ground was very fine, extending for many miles to the S.E., in the direction of Mombasa. In this direction we looked down upon the wilderness of undulating bush country through which we had just passed, while to the N.E. we could see, some twenty miles distant, the hills of Teita or Ndara, another isolated mountain range. Our water supply was derived from a natural reservoir or basin in a rock at the top of the highest hill, about 900 feet above the camp, the ascent to which was steep and difficult. The natives declared this supply to be inexhaustible, and therefore relied upon it even in the driest season.

This experience enabled me to thoroughly realise all the terrible anxieties which must have attended $\mathrm{Mr}$. 'Thomson's march on his return from 'Taveta to Mombasa. He had to do serenty-two miles straight off on 
end, for he journeyed from Ndara to Maūngu, and trusting the natives' report that there was plenty of water farther on at Ziwa-matate, pushed forward at once for that station. He arrived there to find no water, and had to make a forced march to Ariangulu. It is true the return journey is easier than the advance, as it is chiefly down hill instead of up, but I should have been very sorry to have attempted another eighteen or nineteen miles, either up hill or down, on the top of the fifty-three we had just accomplished.

The jungle around our present camp was thick with trees of greater size than any we had as yet passed, and the general appearance of the surrounding country gave promise of better sport. In the morning I shot a quail and a few partridges, and later on in the aftermoon we all went out to look for larger game. I took the direction of Ndara, where the country is more open, and before long sighted a small antelope; some three miles farther on I came across a herd of hartebeest, and at once proceeded to stalk them, a somewhat slow and tedious undertaking, as the ground was very unsuitable. By good luck I got a right and left shot, knocking over a bull and a cow - a rather creditable performance, for I bowled over the latter while she was galloping, and at a distance of about 150 yards. On seeing them fall, the men with me rushed up in great delight, scenting a good feast. These hartebeest (swahiti Kongoni) are of the species known as Cokii, and though uncommon in most parts of Africa, are very plentiful here; indeed later on we often found their presence seriously inter- 
fered with our attempts to stalk other game. They are rather larger than red deer, very high in the withers, and with loug heads; their horns are like one twist of a corkscrew, and the colour of the slim is a light red. They are anything but graceful creatures, but, possibly by way of compensation, have been gifted with singularly rapid powers of locomotion. The horns of the cows are weaker than those of the bulls, but of greater width.

I sent away one man to bring up help to get the meat carried in, and, thinking I could easily find my way back, started off alone. It became dark so soon that had I not fallen in with the fatigue party coming out, I should probably have spent the night in the bush. Eren when I secured a guide it was a most unpleasant tramp, on account of the everlasting thorns the darkness prevented my being able to avoid, and I did not reach camp till nearly eight o'clock. There I learnt that B_ had seen elephants' tracks only one day old, and that $\mathrm{I} \longrightarrow$ had got a shot at an antelope, which he missed.

December igth.-We marched about sixteen miles across the plain that divides our last encampment from the Ndara range, and crossed old buffalo and antelope tracks in addition to fresh ones of zebra. Before we had gone half-way we came upon some fine giraffe in the bush, one, a splendid bull, being not more than thirty yards off. $\mathrm{B}$ - alone had his rifle handy, but while exchanging his cartridges for others with solid bullets, the herd became aware of our presence and 
made off. The only game bagged during this journey was one partridge and a couple of guinea fowl of the horned species.

We encamped near a small stream on a picturesque spot on the S.E. slope of the Ndara range, the hills forming a semicircle on three sides of us. The scenery here is fine and bold, the range ending abruptly at the S. Wr. in a precipice of sheer rock, about 4500 feet deep, which looks as if it had been cut with a knife. In the middle of the semicircle a cupola rises some 5000 feet, while to the south lies a rast and undulating plain dotted about with trees and clumps of bush, only broken towards the S.E. by the inhabited table of Mount Kisigan, which is 7000 feet above the sea level, and about thirty-five miles distant from the hills of Ndara. The summits of the Ndara hills are also inhabited by a people called Wa-teita, and Mr. Wray, a missionary, has devoted his services to their benefit by living amongst them. In the afternoon $\mathrm{H}-$ ascended the hill pass and risited him with the riew to arranging about food for the caravan, for our supplies were now exhausted, and we had several sick men we were anxious to leave under his care. The climate since learing Maungu had changed completely; the elevation of our camp was 2300 feet, and the nights were quite cold, for we had now entirely got rid of the muggy and moistureladen atmosphere of the coast region.

It was most amusing to hear the orders being given out every night by Cačeche, the head-man, who at about seren o'clock took up his position by the loads. 
and amidst dead silence made a speech of about four minutes' duration, in which he told the carriers the plans for the next day; when he had finished, there always arose a perfect babel of voices from the men on all sides of the camp, some murmuring and grumbling, and others shouting out what was intended for impertinence. After about three minutes of this uproar, the men seemed to have thoroughly relieved their feelings, and the camp relapsed into comparative silence.

December 2oth.-Early in the morning we marched round the precipice at the south-west corner of the range to Ndara, a distance of about eight miles. As we approached Ndara, the track led through extensive fields of cultivation, in which innumerable quail got up in dozens, and I am sure we might have shot a hundred couple with ease; however, we left them alone and only bagged four guinea fowl. On arriving at the foot of the highest point of the Ndara range, 5400 feet high, we halted for a time under a splendid sycamore tree near a running stream, of sparkling water, which took its source from the rocks above, and from this point we could just see Mr. Wray's hut, about I500 feet above us; here our men were soon engaged in cooking their rice, as we irrtended to march on again directly they had finished their food. This sort of double march, with a halt to feed in the middle, is termed by the Swahili "a teragase."

Mr. Wray and H_ shortly came down the hill, and the former remained with us till we left, and told 
us a good deal about the inhabitants. He seems to lead a curious and uneventful life in his mountain fastness, where he has resided, for five years, in a little iron hut of two rooms, having returned to the coast only once during that time. He never descends to the plains, except to meet a passing caravan, or to shoot, and he assured us there were eland, hartebeest, and other antelopes and a few lions about. The summits of the hill range form an undulating platean, inhabited and well cultivated. He seemed to live in comparative peace and comfort, but he told us that until a famine occurred about two years ago, he encountered many difficulties, as the natives were always trying to turn him out, because they thonght he must have committed a murder or some other crime, as none of his relations ever came to see him. After his helping them to the best of his ability during the famine, which destroyed quite two-thirds of the population, they began to realise that his presence was productire of good instead of evil, and now they would come and chat with him all day long in his hut, and were most friendly.

'The Wa-teita, of whom a great number' came down to inspect us, differ considerably in general appearance from the Doruma; their features are smaller and their faces rounder, and though by no means beautiful, are not repulsive; they have the curious habit of filing their front teeth into sharp points. Some have their heads clean shaved, others leare a small round top knot of short frizzy hair, and others 
again wear all their hair with a peculiar top knot, which, instead of being round, comes to a point in the centre of the forehead. 'The men wear the usual dirty cloth round the loins, and the women a pleated petticoat of the same material; they adorn themselves with fine iron and copper chains and wind coils of thick wire round the upper arm, in some cases tightly enough to produce bad sores. Beads of two kinds are much affected by both sexes, particularly by the ladies, who in some instances wear orer a hundred rows round their necks. The fashionable and therefore farourite beads, when we passed through, were big blue and small red ones, but the native taste is capricious, and the farourite beads are now probably totally different in size and in colour. Brass coils and ornaments, including small chains, are worn in the ears, and a Wa-teita dandy always rubs his hair over with grease and red clay, while the best dressed ladies anoint their neck, arms, and breasts with rancid butter. The men are very fond of snuff, which they keep in little horn snuff-boxes carried round their necks, and their weapons consist of bows and arrows, the barbs or rather the hafts of the latter being smeared with poison, and so constructed as to be easily detached from the shaft. These barbs always remain in the wound, and produce death in large animals in about twenty minutes. They also have straight short swords of a spatulate shape, and carry curious little threelegged stools, carved out of a solid piece of rood, with the tops hollowed out like a plate; these are 
generally slung orer the shoulder by means of a fine iron chain.

The population in these hills used to number about I0,000, but the recent famine had caused dreadful havoc, and the survivors left their homes for a time, and are only now returning by degrees. The present population did not amount to more than 1500 , and those we saw appeared to be a simple-minded and peaceable community. We were only able to buy three loads of makindi (indian com) and a few sweet potatoes, so after the men had finished their meal, and we had made arrangements about the sick being left behind, we took leave of Mr. Wray and continued our journey. 


\section{CHAP'TER VII.}

Jovia-Native purchases-Mlbugoli and his warriors - Kilima-njaro sighted - Wanton attack on a slave caravan--A weary waterless journeyArrival at Lanjora-Abundance of game-Taveta forest.

AfTer crossing a small srampy plain for about two miles we had a stiff climb of over rooo feet, and then made but slow progress, the track leading for a mile or so through very thick bush, which formed a natural tunnel, in places so low that we had to proceed almost on hands and linees. We only made six miles from Ndara in four hours, and on emerging from the bush, halted for the night on the western side of the slope we had just traversed, where, as the bush was still thick, the men could only form a small circle round our tents, and from fear of lions, said to be plentiful here, kept up good fires throughout the night. The elevation of this position was 3400 feet.

December 2 Ist.-As we had to encamp last night away from any water, we made an early start, and after a short descent crossed a plain surrounded by grand hills, the eleration of the highest, towards the north, being 7000 feet. $\mathrm{H}-$ had a shot at an antelope, probably a waterbuck, but missed it, and B-brought down a partridge or two and flushed some button quail. A three hours' march brought us to a low hill, from the 
summit of which a good view of Jovia, our next halting place in the valley below, was obtained. 'The scenery was lovely, greatly resembling the Highlands in Scotland, only more wild. The valley in which the village lies is partially cultivated and in some parts densely wooded; it runs north right up to the mountains for several miles, and the whole neighbourhood is densely populated. The people live chiefly in the mountains, and come down in the day time to cultivate the valley, which is well watered by a narrow river, the Jovia, flowing due south. Crossing this we encamped on the right bank, and after the tents were pitched began the tedious operation of bargaining for food, which had to be purchased with cloth. 'The mode of procedure was this: each lot of Indian corn was brought into a tent and spread out for inspection: then Cačeche and the natives squatted down and began to haggle over the price to be paid for it, and when this was satisfactorily arranged, a man kept for the purpose, on account of the enormous size of his forearm, was brought forward and proceeded to measure off the lengths of cloth, (Swahili mcono), which were to represent payment for the amount of corn purchased. This haggling continued for the remainder of the evening, and even then we had not bought sufficient corn, so the only thing to do was to continue the performance on the following day. Our purchases also included honey with a curious aromatic flavour, moderate butter, sweet potatoes, and sugar cane, in addition to Indian corn ground and green, which, when fried in butter, is 
excellent and rery satisfying. WVe were offered an ostrich's egg, but as it must have been laid out of season, it was declined with thanks. In the way of fruit we obtained pumpkins and cooking bananas of a yellow colour, which, properly stewed, were rather nice. The banana is the staple food of these natives, who mash and boil the unripe fruit, and thus produce a black compound which, however uninviting in appearance, is undoubtedly wholesome and nutritious.

Seven men ran away last night, and, I expect, remained hiding at Ndara; they were mission men of course, as were nearly all who had deserted up to the present. We had been less watchful, thinking ourselves safe after reaching Maūngu. This defection caused some inconvenience, for what with previous runaways and the sick left behind at Ndara, we were now shorthanded, and had to leave some of our loads at this place and send back for them later on. Our present camp was situated about 2700 feet above the sea, and I 62 miles from Mombasa.

December 22nd.-We spent a quiet day, while the buying of food went on briskly and the camp was full of natives, especially women. These ladies, covered with rows of beads, brought the Indian corn in bags on their backs, suspended by a string from the forehead; they were a particularly ugly lot, and, excepting the very young girls, had breasts like tobacco pouches. 'The children, who accompanied their mothers, were all fat and quite naked, and scarcely less dirty than their parents. 'They were uninteresting. visitors and 
became tiresome, for they gathered in crowds round our tents, remained all day, and did nothing but stare and make grimaces. We tried photographing them, but it was no easy operation, for they looked on with curiosity until we attempted to focus a group, and then fled precipitately. They are exceptionally superstitious and always in dread of magic (mchavi), and would throw away food they had brought to sell, simply because we had touched it. As the grass and cultivation was thick round our camp, and it rained most of the day, we were content to remain idle and watch the negotiations, which resulted before night in the purchase of all the provisions we required.

December $23 \mathrm{rd}$. - T We started at $6 \mathrm{~A}$.M. and crossed, by a very steep path, the lower slopes of Mount Kibomu, which is some 6500 feet above the sea, and the highest of three hills, called the Three Brothers, forming part of a large isolated range. After a march of six miles, and on reaching the cultivation again at the bottom, on the north side of the mountain, a halt for nearly two hours allowed the cararan to close up, and enabled us to march in a compact body through the inhabited part of the valley of Matate, as Martin was afraid we might meet with some hindrance. Mbogoli, the chief, was described as a thorough old blackguard, who would be sure to do his best to get hongo (blackmail) out of us, especially as at that time he was collecting I 500 men to attack the Ughono people near Lake Jipé, an unfortunate tribe who seem to be the butt of all their neighbours. Before starting 
on an expedition of this kind all the warriors make a point of getting drunk with the view of working up their courage to a proper fighting pitch, and as they were armed with poisoned arrows we felt disposed to give them as wide a berth as possible.

While waiting for the caravan to come up, a great many natives arrived in full war paint and passed at a trot, shouting and howling as they went, but without taking the slightest notice of us. They wore hardly any clothing, but were armed "to the teeth" with bows and arrows, short swords, spears, and clubs, and their hair was daubed with red clay. A fer wore ostrich feathers, in addition to their bead necklaces, and wire anklets and bracelets, and the commissariat carried calabashes full of water, sugar-cane, knives and snuffboxes. When the caravan arrived we marched on, and were soon joined by Mbugoli's headman, who politely led the way, and was especially conspicuous from his head-gear consisting of a red woollen night-cap. After we had proceeded for about two miles he tried to persuade us to halt, as his chief wished us to encamp there, but Martin, pushing him aside, declared that it was impossible for us to do anything of the kind. We then continued our march for another four miles, through a fertile valley containing magnificent trees, in full dark green foliage, which in the distance gave them the appearance of gigantic cedars. The woods were full of bees, and the natives suspended boxes, from the high trees, to tempt them to hive. These boxes were formed out of hollow logs about three 
feet in length, with both ends stopped up, leaving one small hole for the cloor.

On reaching the outskirts of the cultivated ground we pitched our camp, and although we heard a great deal of shouting in the hills, we met with no opposition beyond one feeble attempt to detain Martin and the tail of the caravan. Almost as soon as the camp was in order, some of Mbogoli's warriors appeared to announce a visit which their chief proposed to pay us, and of course they inspected us with great curiosity.

We passed the time, while waiting for Mbogoli, by letting off a Pharaoh's serpent, and by showing them a musical mug which played a tune whenever it was raised to the lips, and, needless to say, they were much impressed by these wonders. Soon the firing of two guns and the blowing of an instrument, that sounded like a penny trumpet, announced the approach of Mbogoli and his headmen. The chief was a cunninglooking scoundrel, with the face and head partially shared; his chief ornaments were two necklets of twisted iron wire, one of beads, a single earring of rough design, two bracelets of white metal worn abore the elbows, two others of copper wire on the wrist, a white cotton handkerchief with coloured spots, and a dirty piece of cloth round his waist; the dress of his four headmen was equally quaint and scanty.

He extended to each of us a hand, grimy, scaly and clammy, and sat upon a chair Martin had placed especially for him. We expected the followers to squat on the ground, but his prime minister, not to 
be beat, was proceeding to perch himself on our fragile camp table, which would certainly have collapsed, when Martin anticipated him by a shove, the meaning of which was unmistakable. After recovering his balance, he proceeded to make a lengthy speech, to the effect that Mbogoli was very much hurt that an old friend like Martin should have passed his place without stopping, especially when a bullock had been got ready in his honour, and continued in this strain until Martin interrupted and said we would pay him a visit next time, but that now we were in a hurry to get to Taveta. The Sultan's letter was then translated to him, and we were introduced in turn by our names with the prefix of bwana. Then began the requests for presents, which included four casks of powder and a gun. We eventually agreed to hand over a muzzleloader, two casks of powder, and some cloth, but the latter Mbogoli desired us to keep until he came for it after clark, as otherwise he would have to share some of it with his subjects; this request seemed rather undignified, coming from a chief, but the power of most of these petty chiefs is very limited.

The question of hongo being satisfactorily settled, Mbogoli and his prime minister began racking their brains for further requests, and cast their eyes longingly over the different things scattered about the tent, and began with a request for old hats and coats, and ended by begging for nearly everything they saw ; but we flatly refused all their solicitations. During our interview, which lasted one and a half hours, we 
were of course surrounded by a crowd of spectators, composed of our own men and a highly flavoured contingent of Mbogoli's warriors; most of the latter wore about a dozen small strings of beads, threaded through the upper part of the ears, as well as heary rings in the lobes. 'They appear to pay great attention to the method of ear piercing, and insert round pieces of wood to stretch the holes, until, in some cases, they become from three to four inches in diameter. Such a result is considered a great attraction, as, if there be no split in the process, the lobe is capable of carrying heavy ornaments, but, unfortunately, in the case of Mbogoli's right ear, the tissues had become completely divided, which rendered the wearing of the lower earring impossible. Some of the warriors carried ostrich feathers in their hair, and wore small cloaks made from the skins of leopards, goats, sheep, and antelope, and nearly all were men of fine physique. Mbogoli retired when he found he could get nothing more out of us, but not so the warriors, who kept up a constant din close to our camp, and spent most of the night in howling and singing.

A partridge and a dove, secured by $\mathrm{B}$ - on the march, proved very welcome as they represented all the meat we had, for, owing partly to our being some distance from the abodes of the natives and partly to their being engrossed in war preparations, none of the women had come in to trade. Our present position was 3000 feet above the sea, and I 74 miles from Mombasa. 



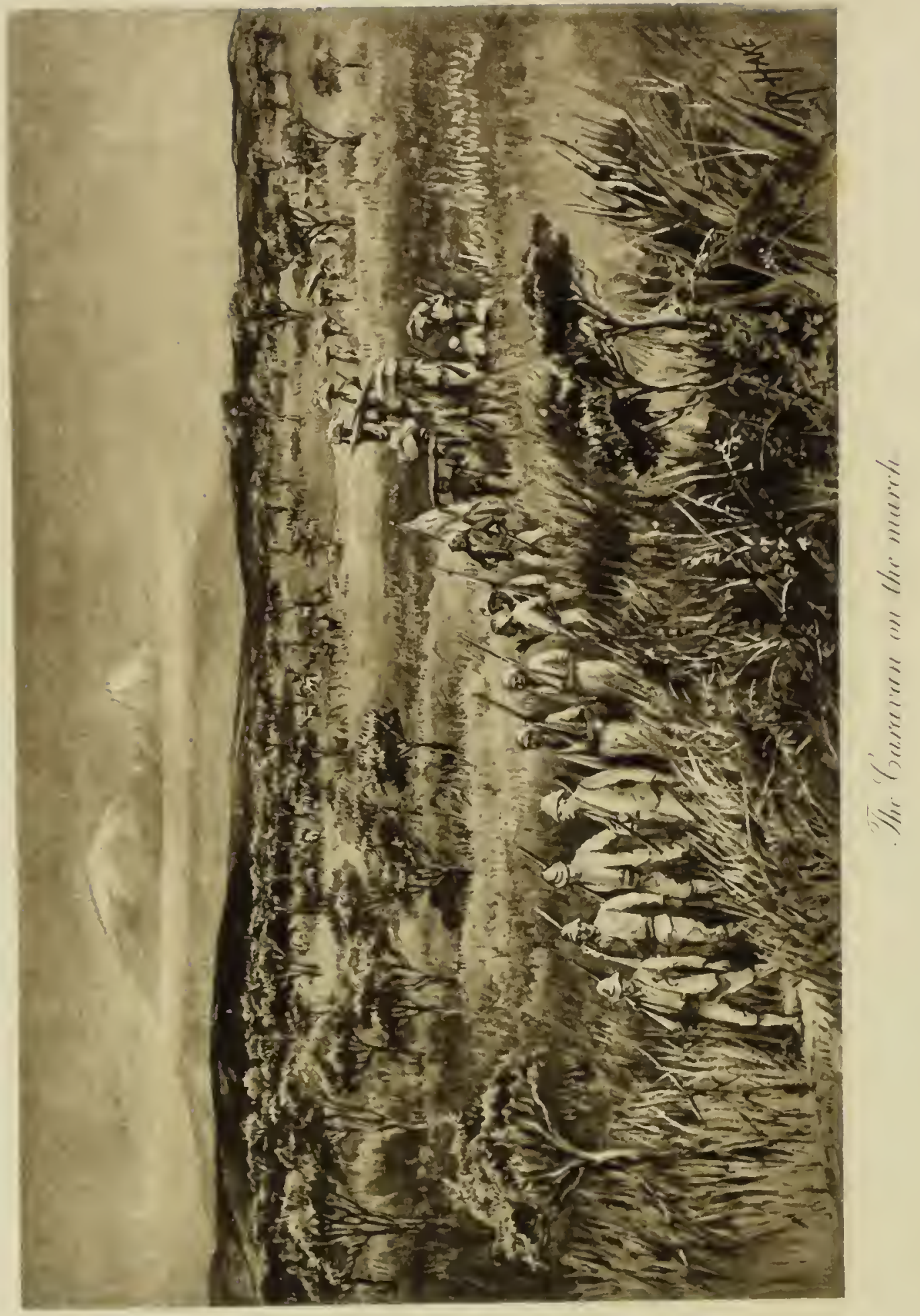


December $24 t h, 25^{t h}$.- The camp was full of natives in the early morning, including a number of women, most of whom wore small red and white beads threaded in their hair, which produced the effect of a mop or big tassel. Our men were busily employed in filling gourds and calabashes with water, as we had a march of forty-five miles through a waterless country before us. We also filled two air pillows and our waterproof sheets; the latter I used frequently for this purpose in the Nile expedition of $188_{4}$, when we had to cross deserts, and they are most excellent makeshifts if one happens to be short of vessels: the ordinary ground sheets will carry from two to three gallons, and may be used many times, before a leak is sprung, if protected by being placed in sacks.

We started about 2 P.M., and the track led us W.N.W., through more thick bush, but after crossing two slight elevations we emerged upon a more open country, consisting of a series of undulating slopes covered with short grass, in most places dry though here and there of a brilliant green, studded with clumps of mimosa and other thorn trees of good size, giving the whole landscape a park-like appearance. Here we were on the fringe of the big game country, and before long fell in with immense herds of zebra, hartebeest, Granti, and mpallah, feeding at no great distance from the track, but we did not trouble to go after them, for fear of delay. After about three hours' march we met a small caravan of thirty slaves, carrying ivory to the coast from Mandara, the chief of the 
Wamoči, a tribe occupying the S.E. slopes of Kilimanjaro. On sighting us, the man in charge sent most of his convoy a distance of some 500 yards off the track, where we could just see their heads as they crouched in the grass, while he adranced cautiously with two or three followers to see whether we were friends or foes.

Soon after passing them we sighted Mount Kilimanjaro, and could make out its huge base stretching from N.E. to S.IV., and the jagged summit of the eastern peak Kimawenzi in addition to the flat snowcapped top of the west peak Kibo, which poked its head just above the dense clouds that enreloped the remainder of the mountain.

At 6 P.м. we halted to allow the caravan to close up before dark, as by then we should be on one of the Masai tracks, and it was wise to be on the safe side, and keep well together in case we should happen to fall in with a war party. Just as we were thinking about halting, we heard firing and shouting some two miles in our rear, which caused no little excitement among the few men who had kept np with us, and they declared the cararan was being attacked. Sharing to some extent their suspicions, we rushed back with our rifles, as hard as we could go' followed by the men who at once dropped their loads; while my black beauty of a servant, who stuck close behind me, brandished, in a great state of ecstasy, my loaded revolver, exclaiming, as he ran, "C'est la guevre, moussou; oui, c'est la guerre!" 
After running back about two miles we found that it was only a false alarm, due to our. infernal mission men, who, brave enough when in the proportion of four to one, had fired on the small slave cararan, with the intention, I suppose, of arenging some former illtreatment they might have experienced at the hands of the traders. The result was that the whole convoy bolted to a man, and when the leader appeared again, shortly after the firing ceased, he complained that his rifle had been stolen, though I expect in reality he had thrown it away, so that he might be able to run all the faster. We expressed our regret for the contretemps, and tried to find out the culprits, but to give the devils their due, I will say the mission men were too loyal to split on their comrades, though we offered a reward. This episode was most annoying, as, apart from the delay of one and a half hours and the consequence of a four mile extra march, it might have led to most unpleasant results, by embroiling us with all the slave traders in these parts, with whom we had no right at all to meddle anywhere inland.

Our journey was resumed at $7 \cdot 30$, and as it was now quite dark, I led the way, carrying one lantern, and Martin brought up the rear with another, but our progress was very slow. Erery now and then we would hear the snorting of zebra and other wild animals, scared by the light as we passed, and we frightened large flocks of guinea fowl from the thorns in which they were roosting. At ro p.x. we halted till two o'clock, but though we were tired enough, it 
was too cold to sleep, and we were glad to start on again at daylight.

At 7 A.m. we rested for an hour, and while waiting for breakfast, I walked half a mile further on, and was rewarded by getting one of the best views of Kilimanjaro that I ever had while in the country, as, except very rarely in the early morning or late evening, it is almost invariably shrouded in clouds. Now it was standing out clear against the morning sky, about thirty-five miles off, in all its sublime and majestic grandeur, rising straight out of the plain, with its huge base sloping gently upwards for about i 5,000 feet, above which, rising another 5000 feet, are its two peaks, Kibo and Kimawenzi. 'The former is flat and wrapped in a mantle of eternal snow; the latter is of lesser elevation and culminates in a pointed and broken mass, and these two peaks, some five miles apart, are connected by a wide and undulating saddle. The first sight of this monster mountain is calculated to excite admiration and reverence, and one can easily understand that the Masai should regard it with a superstitious awe, which induces them to christen it Ngai (IIouse of God).

On my way back to breakfast, I saw two jackals and some pretty green parrots with red breasts; after breakfast we marched on till 10 A.M., and then halted to serve out water, by this time sorely needed. Here we were enlivened by my idiot of a servant (Anole) and the two cook boys setting fire to the dry grass out of sheer mischief; and as the wind reered round, the 
fire came down rapidly in our direction, and necessitated a general stampede; it afterwards spread for several miles in a south-west direction. By way of punishing the delinquents we made them carry the three tents during the rest of the march.

We arrived at Lanjora at I.I 5 P.M., 45 miles from Matate, and 219 from Mombasa; here there is a big hole or reservoir in the rocky bed of a dried watercourse, and the water it contains is fair and plentiful except in the driest season. Although pretty well tired, we were all eager to be after the game which abounds in these parts, so we started out for a stroll in different directions, but $\mathrm{H}$ - was the only one lucky enough to bring home anything, and he bagged two hartebeest. I saw zebra, Kongoni (hartebeest), and Granti, and wounded one of the latter, but did not get him, as the bush was rather thick; Honly saw a few ostriches. All the game was very wild, and the ground, except where there was bush, unsuitable for stalking.

To-day being Christmas we had two bottles of champagne, and gave the servants and headmen a "tot" of whisky. We were informed by Martin when he came up, that we had encamped at the wrong place, this being little Lanjora, and a regular camping ground of the Masai, whose war parties always stop here on their way to the coast, and who also bring their cattle down to feed when the grass is green; but as the other or big Lanjora was situated about three miles farther on, and as there was only a slight chance of any Masai turning 
up at this time of the year, we elected to remain where we were.

December 26th. - We struck our camp at 6 A.M. and left at 6.30 , and as we were now only twelve miles from 'lareta, I thought I would try for big game on the way, so taking Kibolio (Hippopotamus), moved off to the right of the bush, intending to march parallel to it. I soon saw numerous Kongoni and Granti, but they were all too wild to approach without a stalk, so I left. them alone. Later on I started a small gazelle out of some long grass, and as he stopped to have a look at me about a hundred yards off, I got a shot, and he fell dead in his tracks. It was a small steinbock, about half the size of a roe-deer, and rather lighter in colour, with smooth straight horns about four inches long. Kibolio proceeded to cut a stick on whích to carry our trophy, and we then continued our march.

About an hour after learing camp we struck the cararan track which here winds to the north, and crossing it, we came upon thick bush intersected by game paths made by buffalo, rhinoceros, elephants, and antelopes in the rainy season. After wandering about in this direction for two hours, I got a view of Lalie Jipé, which lies about twelve miles S.F. of the forest of Taveta, on the east side of, and at the foot of the Pari mountains, a high range of hills extending from N. Ir. to S.E. The N.W. slopes of these mountains are inhabited by the Ughono people, against whom the Wa-teita were about to make a raid when we passed throngh Matate. I am informed that there is plenty 
of iron to be found in these mountains, and that out of it the natives malie their knives, spearheads, and chain ornaments, but as we never visited them, though we were sereral times quite close, I cannot vouch for the truth of this statement.

At about Io A.M. I heard a succession of shots a long. way off to my right, from which I rightly gathered that the cararan had now arrived at the entrance to the forest, and were firing the customary salute; a few minutes afterwards a large herd of mpallah, no doubt startled by the reports, came bounding past me through the bush about forty yards off, but unfortunately there was no buck amongst them. They were immediately followed by a herd of hartebeest, out of which I bagged a fine cow. We then made for the Taveta track, which we struck after two hours' wandering, the last hour taking us along the outskirts of the forest, through patches of tall coarse grass, dotted with dwarf and dhoom palms.

Shortly after reaching the track we entered the dense forest by a very narrow and tortuons path; twenty minutes farther walk brought us to a strong palisade built up with logs and trunks of trees penetrated by a small opening measuring about four feet by three. Once through this, we soon came upon the inhabited parts of the forest, as the interior has been cleared by the natives and cultivated. The track led through large plantations of bananas, and small plots of Indian corn, intersected by tiny rivulets of clear water, and before long we came upon children tending 
goats and cattle, and met several of the natives who seemed pleased to see us, and greeted us with handshaking and jambos.

I reached the camp at 2 P.M. , thoroughly tired and rather footsore, which was not astonishing after a tramp of about eighty miles in the last forty-eight hours. I found $\mathrm{H}-$ and $\mathrm{B}-$ at Iuncheon with Mr. Jackson, an Englishman, who had been spending the three hot months at Taveta, and judging from the long rows of skulls and skins spread out to dry in the sun, he had done very well. His bag consisted of seventeen rhinoceros, ten buffalo, thirty-eight hartebeest, two lions, numerous varieties of antelope, besides wart-hogs and hyænas; a respectable collection, seeing that up to that time he had onlv been shooting in the immediate vicinity of 'Tareta. 


\section{CHAPTER VIII.}

Taveta camp-The effect of shooting a giraffe during the march--Taveta forest-The Wa-taveta-Discharge of the Mission men-House-building, drinking, and dancing-A death-Departure of $\mathrm{B}-$ - and Mr. Jackson-Game-pits-A disgusting ceremony.

Taveta is a little over 230 miles from the coast by the road, and about i 70 miles as the crow flies from Nombasa; and our present camp, the elevation of which was 2400 feet, presented a very neat appearance. The ground belonged to Martin, who, during his trip through Masai-land with Mr. Thomson, had occasion to stop here some weeks and bought the plot, which was then covered with its virgin forest growth. After clearing this away he built a house for himself and his stores, and huts for the men, these latter forming three sides of a large square, the fourth side being bounded by a sparkling little river well stocked with fish. A thorn hedge with a strong gateway surrounded the clearing, the centre of which was adomed by a high flagstaff flying the union-jack when the camp was occupied. On the outside a variety of majestic trees of great height, their massive branches clothed with thick foliage, partially protected the camp from the fierce heat of the mid-day sun.

$\mathrm{B}$ — told me he shot a fine giraffe on the march 
from Lanjora to Tareta, and that the scene which followed beggared all description. The nearest porters, excited by the prospect of meat, of which they had tasted so little on the march up, threw down their loads and hurled themselves upon the carcass as one man. They had the skin off "in no time," and then worried the flesh, fighting and squabbling like a pack of famished hyænas. The entrails seemed to be the tit-bits most sought after, and some of the men, being in far too great a hurry to think of cooking, merely tore the meat from the bones and crammed it into their mouths raw. This episode, of course, delayed the cararan a long time, and $\mathrm{B}$ - said he was determined, in future, not to shoot at anything on the march, unless it happened to be some rare specimen.

Mr. Jackson very kindly offered to take one of us on a shooting trip with him, while the rest went in search of game in some other direction, and this arrangement exactly fell in with our proposed plans. We were expecting $\mathrm{B}-$-'s brother $\mathrm{C}-$ to arrive shortly; he had left England a month after us, and was to be accompanied by mission men as far as Ndara, where fifty of our people would meet him as an escort for the remainder of the distance. We also had to send back all our own mission men, and at least twenty natives would be required, for some time, at Taveta to enlarge the camp and build a big house for ourselves; therefore, taking into consideration about twenty-five sick men, besides deserters, there was only left an available force of forty, an insufficient escort 
to take any distance; moreorer, as C-_ was due during the first week in January, it would hare been rather hard on him to have found us all away, and our exact whereabouts unknown. It was therefore decided that B- should start off with Jackson at once, and shoot for ten days at Rhombu, about sixteen miles north of 'Taveta, while H__ and myself were to remain in camp a few days longer, and then shoot the neighbourhood of Lanjora.

'The forest of Taveta, some seren miles square, is bounded on the north and east by more or less open plain and bush, on the west by the lower slopes of Kilima-njaro, and on the south by the Pari or Ughono Mountains and Lake Jipé. The interior has been cleared away to the extent of about ten square miles by the natives, known as the Wa-taveta; the soil of these clearings is most fertile, and produces large quantities of bananas, Indian-corn, beans, mtana (a native grain like millet), wild tomatoes, yams, sweet potatoes, sugar-cane, and coarse tobacco. It is probably capable of growing anything, and of yielding large profits to the cultivators. Even the coarse tobacco grown here and sent to the coast sells for one rupee per lb., at which price, after paying the cost of purchase and carriage to the coast, in addition to the duty of thirty-seven rupees per load of serenty-fire lbs., it yields a profit of over 100 per cent. 'The Wa-taveta also raise herds of small cattle, sheep, and goats, which are tended by the women and children.

The outer fringe of forest has not been interfered 
with, and the impenetrable maze of jungle-growth forms a natural rampart which can only be traversed by means of four narrow winding tracks known as the Lanjora, Useri, Kahé, and Pangani paths. These, when there is any fear of attack from outside, are effectually blocked by cutting down a few trees and letting the timber fall across them, while the main gatervays are also built up with logs.

Here, secure in their stronghold fastness, the Wa-tareta live a peaceable and unerentful, though somewhat idle, life; the men do no work, as what little there is to be done, such as scratching the soilall that is necded before it receives the seed-reaping the harvest, tending the cattle, and cutting wood, is performed by the women and children. They are on friendly terms with most of the neighbouring tribes, and those who are hostile have learnt by bitter experience the dangers of any attempted molestation. Even the warlike Masai have ceased from their attacks after several fruitless efforts to invade this stronghold, for the Wa-taveta, though essentially unwarlike and unaggressive, know how to defend themselves when assailed.

Apart from the impenetrability of their forest, another great reason which renders them so secure is, that even in the crent of being taken by surprise and an entry effected by a hostile force before the paths could be blocked up, there is no regular village to be found inside, and therefore nothing rery tangible to be attacked. The inhabitants live in beehive huts made 
of plantain-leares, each family occupying its own shamba (cultivation plot), on which as a rule there are only two huts, the parents and younger children using one, and the elder children and their families the other. Consequently the utmost an enemy could achieve would be to kill the first few they came across, while in the meantime the war-cry would be sounded and the entire male population, many of whom are armed with rifles, would have time to collect and shoot down, from secure ambushes, the rash invaders. The brave Masai, accustomed as they are to fight only in the open, and to rely entirely upon their long spears, short swords, and shields, would be very soon disposed of in an enclosed and, to them, strange country, every inch of which would be perfectly known to its defenders.

Thus it comes about that Taveta remains a calm and peaceful Arcadia in the very centre of innumerable tribes of howling savages always fighting and robbing one another. 'Taveta is also the great head-centre of all the trade-routes which lead to the far interior, and the large caravans of ivory and slave traders make it a resting-place, to recruit and lay in stores of food, before starting on their arduous and dangerous travels through Masai-land.

The Wa-taveta are a more intelligent-looking race, and far more cleanly in their habits, than any of the tribes to be met on this way up from the coast; their features are comparatively regular and their countenances less repulsive, but they have the same habit of 
anointing themselves with red clay and grease as all the other local savages. The men do not shave their heads, but cut their hair quite short, and all have iron and copper ormaments and chains round their necks, ankles, wrists, and upper arms, in addition to wearing beads and in some cases ostrich-feathers. 'They pay great attention to the stretching of the ears, and the favourite kind of ear-ring is a tube of tin about one and a half inch long, coiled round the lobe, to which are attached small strings of beads and finely-wrought iron chains; the upper part of the ears are often pierced, and thin sticks about eight inches long placed in the aperture so as to slant backwards; these produce a decidedly Mephistophelian appearance. They generally carry snuff-boxes of various designs and curious workmanship, suspended by a small chain from one of their necklaces, and of these the most highly prized are made from the tip of a rhinoceros-horn, artistically ornamented with beads and little iron and copper chains. A piece of cloth looped up orer one shoulder and hanging down to the knees forms their only clothing; and spears about six feet long shod with twelve inches of iron, short spatulate swords in leather scabbards, knob-kerries of hard wood or rhinoceros-horn, small shields, bows and arrows, and muzzle-loading guns, represent their weapons.

The women are altogether more pleasing than those of other tribes we met, and have better figures; the majority are quite black, but we noticed a few witl complexions the colour of café-au-lait. If it rere not 
for the habit of shaving their heads, loading themselves with beads and iron ornaments, and disfiguring their ears by stretching them to such unnatural lengths, some would be almost pretty. 'They bind rows of beads tightly round the head and hang numerous coils of the red and blue rariety round their necks, in addition to several iron and copper hoops and perhaps a string or two of scented grass seeds: besides all this, they load themselves with long strings of red and white beads, arranged like crossbelts over the breasts, and with other's encircling the waist, wrists, arms, knees, and ankles. The latter are often beautifully worked on strips of leather in many varieties of design. Every lady has a cotton petticoat, and those who are married wear, as a distinctire mark, coils of brass wire as earrings looking like Catherine-wheels, from which, if the ears will stand the strain, are hung bead and chain ornaments. The virgins are content with simple beads.

The more of these beads a woman can display upon her person, the better dressed she is in her orn opinion and in that of her friends, and her wealth is estimated by the number she wears. Indeed, cloth and beads may be considered the coin of the realm here, whereas the Caga and Masai tribes prefer iron and copper wire. Pregnant women, in addition to the other ornaments, have rattles attached to their ankles, intended to give warning of their approach, and thus to obviate the chance of being startled by any one suddenly coming round a corner. They also enlist the serrices of elderly ladies as chaperones. The children mostly run about 
naked, though some are decorated with a piece of cloth hung round the neck or a small string of blue beads.

The manners and customs of these people are very primitive. Without any regular chief, they are governed by a certain number of elders, whose duty it is to keep order and punish offenders, to demand and reccive tribute (hongo) from the caravans passing through their dominions, and to sce that, after keeping the lion's share for themselves, the balance is fairly distributed amongst the others.

The ceremony of the hongo is quite an imposing spectacle. First a bullock is presented to the newly arrived cararan by about a hundred or more of the elders and some of the warriors, who advance in slow time, halting every few yards and singing a sort of solemn chaunt. On approaching the camp they form a solid oval phalanx, and with shields held up and spears poised, advance into the enclosure still chanting, and preceded by scouts who dance wildly round them. This part of the performance being concluded, the phalanx halts and the spears are stuck upright in the ground, while the natives, seating themselves quietly round the cararan leader, procced to the main business, the settlement of how much hongo is to be paid. This occupies a long time, as the clders invariably ask at first for more than they expect to get, or the cararan intends to give.

With us they bargained for such excessive terms, that Martin told them if they did not agree to ours he would make up a Swahiti hongo sucl as the 
Swahili caravans give, meaning a certain quantity to each man, the total of which would not have nearly amounted to as much as we were offering them. Upon this threat they modified their demands, and received a mixed load of Americani (cotton sheeting), coloured cloth, and some iron wire. The question of hongo being satisfactorily settled, the crowd dispersed quietly, each man going his own way.

The Wa-taveta religion is anything but complex; they simply worship the spirits of their ancestors, and reverence in a small degree the sun and the moon. In common with all the other tribes, the curious custom prevails of making blood-brothers, a ceremony performed in the following manner:-

A goat or sheep haring been slanghtered and cooked, the two men about to become brothers make a small incision in the fore-arm above the wrist, and just deep enough to bring blood; each then smears a piece of the cooked meat with the blood of the other, and having swallowed it, licks up any blood which may afterwards be left on his brother's arm, who is now his sworn friend for life. In the same way treaties of friendship and alliance are sealed between the various tribes. Martin is a blood-brother of the Wa-taveta, the Moči chief Nandara, the Kiboso chief Sina, and of many other notabilities. I witnessed the ceremony performed between him and a representative of the Ughono people in a rather unusual way, for Martin enlisted Cačeche, our head black man, as proxy to eat the meat and to lick the blood from his Ughono brother's arm. 
T'he Wa-taveta are believers in magic and omens, but not to the same extent as most of the other tribes. They seem to have scarcely any vices, and are exceptionally honest. We never lost a single article during the time we were in their territory, although the camp was always full of visitors, who had every opportunity to steal odds and ends left lying about. On the whole they struck me as a most harmless people, simpleminded, child-like, and disposed to treat us all with friendliness, particularly Martin, who was quite a popular person. Indeed, their friendliness at times amounted to a nuisance, for if they had nothing better to do, numbers would spend the whole day in our camp whenever we were there, and whether we were "at home" or not, insisted on entering our tents or houses, and in bringing at all hours of the day presents of milk, honey, and fish, for which, of course, we had to make a suitable return in the form of beads or cloth.

The early days after our arrival were fully occupied. First we had to call the roll and arrange the discharge of the mission men and others who were unfit for work. Our original complement was found to be diminished by forty deserters, fourteen being Zanzibaris, and the remainder mission men, who had relieved us of seven valuable rifles in addition to their own valueless presence. Then there was our house to be built, and a garden to be made, for which we had brought with us all sorts of seeds and produce, such as potatoes, onions, lettuces, radishes, peas, beans, \&c., though 


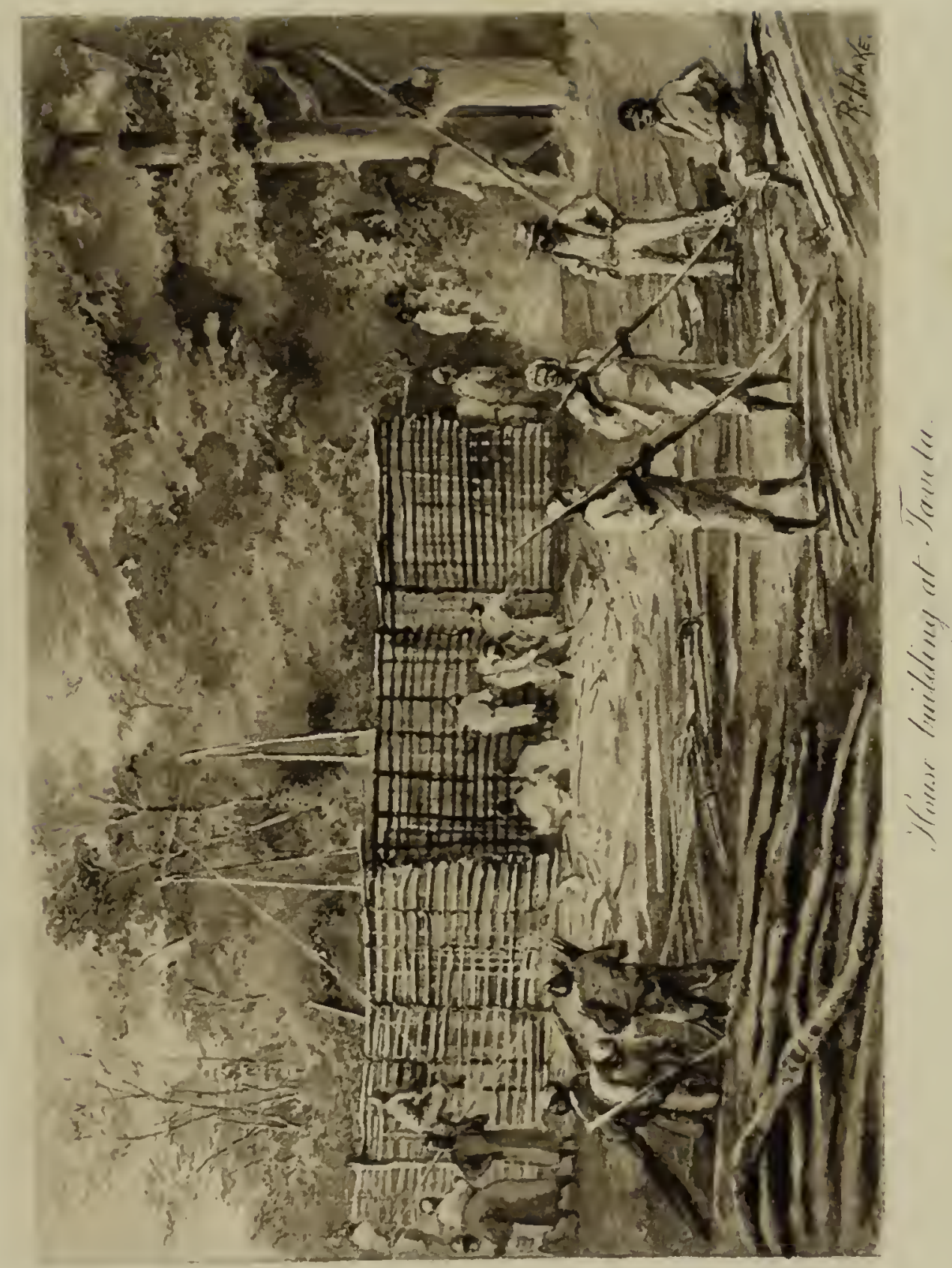


unfortunately nearly all the potatoes had been lost on the way out and most of the onions had gone bad. H_ took charge of this department, and proved a most efficieut and industrious gardener. I went in for doctoring some of the invalids, and trying my hand as a cobbler, for our boots by this time were in a very bad state, and we had quite given up any hope of recovering those we had lost. Travellers might take warning from our experience, and remember it may be a bad thing to put all their boots in one basket!

I bought the half-dressed hide of a sheep, and was getting on capitally, having completed one pair of leather socks, which fitted fairly well, when, as a delightful surprise, our Askari Chandi and the three men we had despatched in search of the runaway arrived with the missing boots and rupees. They had followed the deserter right back to Mombasa before they caught him, and had also captured four other deserters, from whom they recovered two rifles and eleven rupees. These rascals were handed orer to the Governor of Mombasa, who had them well Hogged, and then sent the one who had had charge of our boots under a guard of two soldiers to point out the exact place where he had thrown down his load.

One of our men came to sad grief soon after our arrival at Taveta, for the poor fellow fell into a pit of burning rubbish, and had nearly all the skin burnt off both legs; he bore the pain, which must have been intense, with singular fortitude, and though we dressed his injuries with raseline and cotton-wool, a long time 
elapsed before he was able to get about. Hitherto we had been particularly lucky in our freedom from accidents: Jackson on his march up was less fortunate, one of his men being seized by a lion and having his head teribly mauled.

While arranging our business we went out in turn to shoot for the pot, and generally obtained a few guinea-fowl, florican (lesser bustard), partridges, and yellow-throated spur-fowl. Our men were in high spirits at this time, for 'Taveta to the Swahili is quite the gay Babylon of these parts, and numbers were in a state of perpetual drunkenness from the effects of pombé, a popular native brew. 'This compound is made from bananas and mance boiled together and left to ferment for some days; it appeared to me to have the double objection of being disagreeable in flavour and intoxicating in effect.

The nights were occasionally cnlirened by one of the topical dances peculiar to the Zanzibaris. 'The performers move in single file with a step something. like that of our polka, accompanying the motion with an improvised chaunt. They are fantastically arrayed, some figuring in a head-dress comprising whole skins and feathers of a cock, others wearing startling red garments; a great many had attached to their ankles curious rattle-boxes made of plaited glass containing peas, and by stamping on the ground marlied the time whenerer the tune changed.

Some years ago the Sultan of Zanzibar tried to repress this dance, because during the improvised 
chants the performers were in the habit of abusing their masters and the Government, and airing their grievances in general; but he was obliged to give up the attempt, as the temporary probibition nearly caused a serious riot. Martin told me that several Europeans had experienced grave trouble with their caravans by prohibiting this dance, which, after all, only represent a safety-valve and a form of amusement comparatively harmless, even if it does include such epithets as "stingy brutes, cows, pigs, and dogs," being applied to caravan employers. 'These dances would last a long time, and were conducted in line in front of our tent, or in a large circle, or in a serpentine form round the square; by degrees the string would become less and less, as those who were exhausted retired, until only one man would be left.

I was horrified one day to discover, in a small hut, a wretched Rabai man, called Belail, very ill and utterly neglected; he had been deserted by the discharged mission men, and none of the others seemed to care what became of him, and for two days no one had even visited him. I found him lying in a filtly state, perfectly unconscious and groaning as if in great pain, but failed to discover what was the matter with him, as he could not speak. However, I at once dosed him with beef-tea and brandy, and on the following day, after taking some ammonia, he awoke from his stupor, crying for food and water, and when these werc brought, ate and drank as much as I dared let him. He had to be fed in our presence; otherwise; Martin 
declared, the man told off to look after him would eat the rice himself! The poor fellow rallied for a few days, and then, though he kept on improving in bodily health, went mad and howled like a hyæna day and night, and in this condition lingered on for nearly a month before he died.

Jackson seemed to be on excellent terms with the natives; he was collecting insects, and every minute of the day the small boys would arrive at his hut with all sorts of specimens, and he would now and then send them off highly delighted with a string of beads or an old empty cartridge-case to repay them for their trouble. He told me he could not understand what Mr. Johnston meant when he stated that the variety of insects in these parts was very poor, as he had in three months made a very fine collection of curious and beautiful beetles and butterflies. We afterwards found that our views on many points regarding the country and people differed considerably from those which Mr. Johnston has expressed in his book on the Kilimanjaro Expedition.

'The Lumi, a little river running past our camp, takes its rise in the north-west slopes of the mountain, and flows through Taveta forest into the north end of Lake Jipé. It is a narrow stream, measuring only about thirty feet across its widest part, but the banks are steep, in most places ten feet high, and the water rather deep. I tried my hand at fishing without much success, as the tackle I had was too thick. The natives were great adepts, and by means of a rod made out of a thin palm- 
branch, and a fine line, woren from palm-fibre, liept us well supplied with fresh fish for breakfast; their average weight was two to three lbs., and though full of bones, they were by no means bad eating.

After two days' rest $\mathrm{B}$ - and Jackson started off to Rhombu, and $\mathrm{B}-$, being anxious to shoot something on the march, got off very early. I accompanied Jackson part of the way later on, and after a twenty minutes' walk through the Useri path, emerged from the forest on the north-west side. We then went on through open country for about two miles in the direction of the wonderful subterranean lake Chala, which I shall have occasion to describe later on ; here we separated, Jackson going north to Rhombu, while I, turning to the left, ascended the lowest slopes of Kilima-njaro and walked a long way without seeing anything except a few zcbra and hartebeest. At this time of the year ererything is so dried up that it is not much use looking for game except in the low ground or near streams. While proceeding in this direction I met with what might have been rather a serious misadventure, but as it turned out I suppose it savoured of comedy rather than of tragedy. I was swinging along a pass between two small hills where the grass was dry and smooth and the path apparently well trodden by game. Suddenly the ground gave way under me, and I found myself supported by my arms, with my legs dangling in space and vainly struggling to reach something more solid. Casibete and the other gun-bearers rushed to my assistance, and soon extricated me from my undigni- 
fied and equally uncomfortable position, and explained, what I had almost realised without explanation, that I had tumbled into a game-pit. A careful survey of this scene of my abasement disclosed a funnel-shaped trap about twelve feet deep, and three feet wide at the top as against only one foot at the bottom: this, unlike many others, was luckily free from spikes and stakes, but the way in which the mouth was concealed by the smooth and well-trodden grass was most creditable to the artist who had planned and arranged it, and I should imagine quite capable of deceiving an animal with four legs as well as one with only two.

During the afternoon I came upon zebra, hartebeest, and eland, on ground quite unsuitable for a stalk, being free from undergrowth and merely studded with tall thorn-trees about fifteen feet apart, much resembling an ordinary English orchard. I obtained one shot after a very tiresome crawl, and thought I had hit, as the creature made a great bound; but he never left the herd, so I hope I was mistaken. Nearer home I shot at a hartebeest, hitting him too low, so that he led me a long dance before I succeeded in bagging him.

It was now getting dark, and we were nearly five miles from home. I thought if I got on the Caga track, which was close by, I might safely leare the men to cut up the hartebeest, and could easily make my way back; but the Caga track through the forest is much longer than the others, and not nearly so well defined. The result was, that after falling into several wart-hog holes outside the forest, I erentually got off the track 
inside the forest, and found myself most effectually hung up in the dense jungle. There, after using all my matches in fruitless efforts to discover the path, and having fired three shots to attract any natives who might be near, I waited till my men came on, and occupied myself with shouting at the top of my roice every minute lest they should pass by unawares. After continuing this exercise for about an hour I was much relieved to hear Casibete's reply, and was soon, with his assistance, able to force my way back to the track from which I had wandered quite two hundred yards. Eren then our troubles were not over, for the men with me, who knew the path well, had great difficulty in keeping to it on account of the intense darkness; added to which we had to cross several streams, by means of bridges of felled trees, so our progress was very slow and we did not get back to camp till IO P.M. Here I found everybody had gone to bed, thinking that I intended to stop the night at Jackson's and B-_'s first camp. After a little delay I got something to eat, which I much needed, having tasted nothing but a chupattee (flat pancake of flour) since 7 A.M. Nartin informed me that a big Masai war-party had been seen passing Lanjora to-day. It was fortunate they did not pass three days sooner, as they would then have come across us.

The Wa-tareta were having a fine howl and singsong to-night, as a deputation from a friendly tribe occupying the neighbouring forest of Kahé had come in during the day to announce a successful fight with the 
Caga people who had been stealing the salt, to be found in great quantities, in their territory. $\mathrm{H}-$ had been to witness their reception in the early part of the evening, and described how a bullock was led into the midst of the throng, followed by a Taveta elder, who took a mouthful of milk and spat orer it; the chief of the Kahé people then did the same, after which another Taveta man half-killed the animal by a cut about six inches behind the head, and gashed it about the neck; then, after tying up the main arteries, the elders and Kahé people proceeded to suck the blood while the poor beast was still alive. He was so disgusted with this sight that he came away and did not witness the conclusion of the ceremony.

The following day was most eventful and lucky. Early in the molning a native brought in my fieldglasses, which I had lost in the jungle the night before, and later on Chandi and the other men came in with the recovered boots. 'The former reported they had met lots of Masai on the road, but had kept out of their way. In the afternoon a man came in to report that $\mathrm{B}$ - had lilled a rhinoceros, which must have been a rery tough beast, as he required twenty shots before giving in.

II__ and I stayed only two more days after this at 'Tareta. Our loouse making good progress and things getting ship-shape, we decided to encamp with thirty men at big Lanjora for a few days, and then to revisit Taveta before paying our respects to Mandara, chief of Moči, a C̆lıaga tribe inhabiting the southern 
EXAGGERATED IMPORTANCE OF MANDARA. 95 slopes of Kilima-njaro, of whose importance we had conceired a highly exaggerated idea from Mr. Johnston's book, which led us to suppose that it was essential to go and conciliate him before attempting the regular business of shooting. 


\section{CHAPTER IX.}

Sport at Lanjora-Return to Tareta-Departure for Mandara's countryH_-'s first buffalo-Arrival at Moči.

THE morning of the day on which we had decided to leave for Lanjora, a native came into camp and reported a buffalo on his shamba (plot), and I was idiot enough to believe him, and to start on a wild-goose chase. He led me right to the southern end of the forest, about two hours' walk, and when we got there the buffalo, of course, had disappeared, and all I saw were a number of monkeys, guinea-fowl, and partridges. If a native says a place is near (karibu), one may be sure he means any distance from one to four miles off at least. Their favourite expression is always karïu kictoggo (a little near), which means any distance from three miles to ten. They seem to have an objection to use the word embali (far) unless they are referring to a distance of over five hours' travel.

In the afternoon we started for Lanjora. On the way I had a shot at a splendid cock ostrich about two hundred yards off; he fell over when I fired, but getting up again, almost immediately, ran off like the wind. After that I saw numbers of Grantii and hartebeest, and proceeded to stalk them, but while doing so a herd of eight fine $\underset{96}{g i r a f f e}$ came feeding in $m y$ 
direction, so, as we wanted meat, I thought it best to wait. It was a rery pretty sight to see these graceful animals gliding smoothly over the ground with stately step, pausing here and there to pick the tit-bits off the tops of the highest bushes. No creatures are more graceful than giraffe in their slow paces, but directly they break into a gallop their action becomes most ungainly. This herd had fed to within about I 50 yards of me, when I heard a gun-shot, some distance to my right, which I suppose came from H-. As the giraffe seemed startled by the sound, I was afraid to wait any longer, and fired with my $450^{\circ}$ express at the point of the shoulder of the nearest beast. I heard the thud of the bullet, but it could not have broken the shoulder, as, though the wounded animal lagged behind the rest, I was unable to get up to him. Probably the best place to aim is high up at the point where the neck joins the body, for anywhere else, in my experience, they take a lot of shooting.

As it was now getting late I sought our camp, which I found ready pitched at big Lanjora, half-amile off the main track, and practically safe from the Masai who only come here in the event of the watersupply of little Lanjora being dried up. A capital spring of pure water here rises from the rocks, and forms lower down a succession of large pools, where, judging from the numerous tracks leading up to them, many animals come down to drink. Our camp occupied a little hollow, shaded by big mimosas, and had a very snug appearance with its hedge of 
thorns to keep out the wild beasts at night, or the Masai, in case they should put in an appearance, in the day-time. Lanjora is surrounded by more or less open plain on three sides, and on the south side towards Lake Jipé by thick bush. Our first night's rest was broken by an inquisitive rhinoceros, who polied his ugly nose over the hedge, and so frightened one man that he let off his rifle. We were also somewhat disturbed by lions growling round the camp until the "dawn of morn."

During the three days spent at Lanjora we each made a daily shooting trip in different directions, starting at 6 A.M., accompanied by five or six men to carry our rifles and bring home the meat lilled, and returning to camp between $\mathrm{I} 2$ and I P.M., to aroid the excessive heat of the midday sun. We had very fair sport, and saw abundance of game, zebra, hartebeest, Granti, mpallah, oryx-beisa, ostriches, giraffe, and steinbock, but found all excessively wild and difficult to approach; the hartebeest and zebra were a great nuisance, as, when disturbed, they would gallop about wildly in every direction and move all the other game.

The soil in these parts is very light and of a bright red colour; it is studded with ant-heaps, which in some cases attain the height of eight and ten feet above the surface of the ground and are several yards in circumference. These ant-heaps, the tops of which are perforated with innumerable holes a few inches in diameter, assume most grotesque shapes; in some 



\section{PLATE I.}

No. 1. Male hartebeest (Alcclaplus cokii); length of horns from base to tips I I $\frac{1}{2}$ inches, width between the tips I $7 \frac{1}{2}$ inches.

No. 2. Male lesser kudu (Strepsiceros kudu); length of horns from base to tips in a straight line 17 inches, widtb betwcen the tips 14 inches. Shot in thick bush near Lanjora.

No. 3. Male mpallah (Melampus pallah), shot near Useri; length of horns in a straight line from base to tips 20 inches, width between the tips I 8 inches.

No. 4. Male waterbuck (Kobus sing sing), shot near the forest of Tareta; length of horns along the bend $2 S$ inches, width betwcen the tips I $S$ inches.

No. 5. Male bushbuck (Tragelaphus 'sylaticus), shot on the Weriweri River; length of horns along the bend $1 \frac{1}{2}$ inches, widtb between the tips 4 inches. 


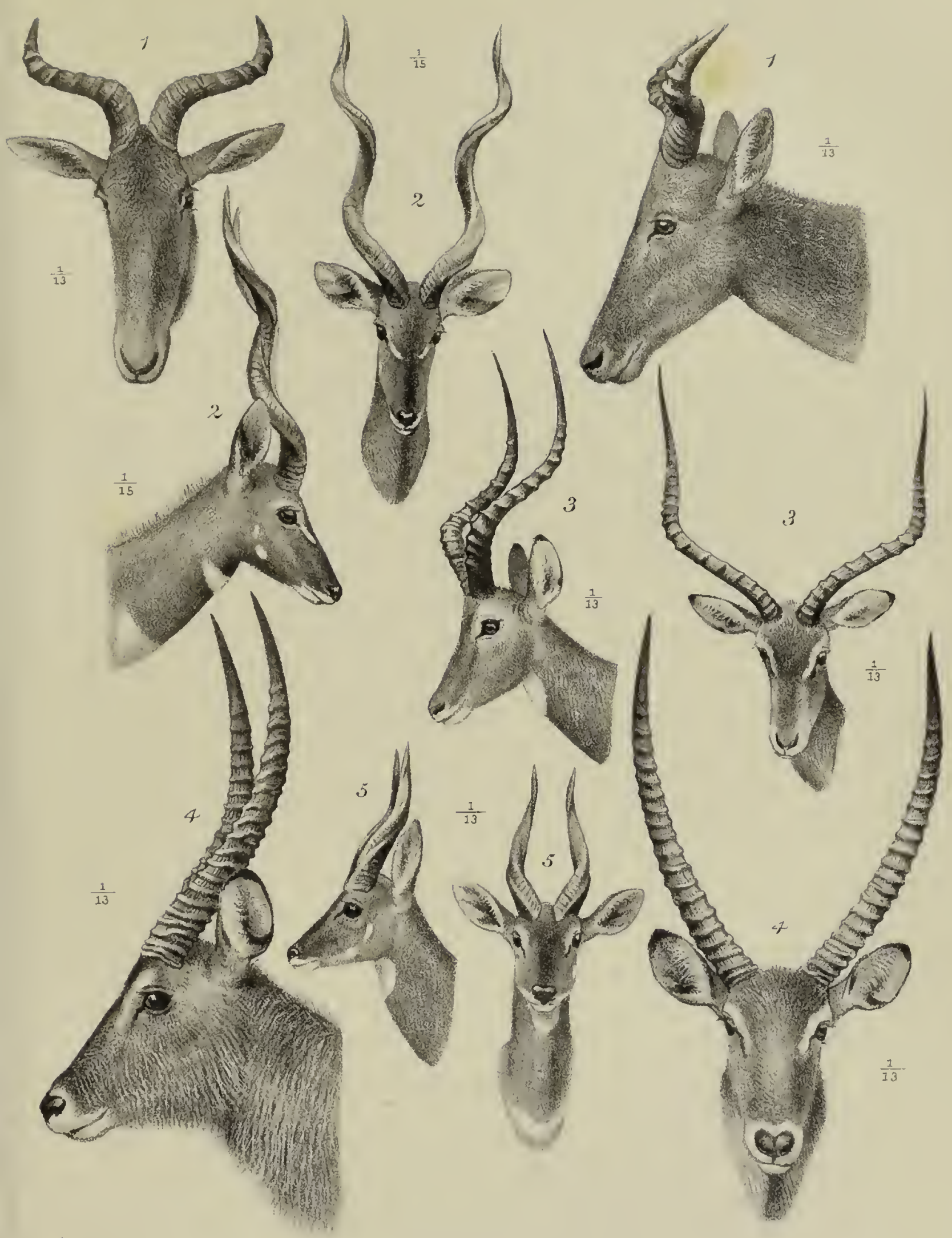



instances they terminate in long shafts from fifteen to twenty feet in height, looking exactly like small factory chimneys. At a distance of a mile or so they are apt to be rather misleading, as they may easily be mistaken for a herd of animals, but I cannot say we were ever short-sighted enough to mistake them at a short distance for hartebeest, as Mr. Johnston says he did, for they are almost alvays at least four times as large.

The first day $\mathrm{H}-$ shot one hartebeest and a steinbock (Swahili Isha), and I shot a hartebeest and a good specimen of a Granti (Swaliti Swara), the latter, a pretty little antelope rather smaller than a fallow-buck, is of a light fawn colour, with beautiful annulated horns from two to two and a half feet in length, which curre first gracefully backwards, then outwards, and finally forwards at the points; the females are smaller and lighter in colour and have thin and nearly straight horns from fourteen to seventeen inches in length. I also saw some oryx-beisa antelope, but they went off at full speed before I got within eight hundred yards of them. Our afternoon was occupied in slinning the heads of the Granti, hartebeest, and steinbock, and in making a platform in a tree near the largest pool of water. I was anxious to try and get a shot at a lion by sitting up during the night, as, from their numerous pugs, they were eridently in the habit of coming down here to drink.

We sent back to Taveta all the meat we did not require, for Martin was at this time buying up a large 
stock of grain for the men, and as the natives would readily exchange their grain for our meat, the more we sent to Taveta, the better we were able to economise our stock of cloth, \&c. As to our own commissariat, what with small gazelle renison, guinea-fowl (horned species), yellow-throated spur-fowl, and sand-grouse, we did not fare badly; the latter differ from those I have shot on the Nile, in being larger and of darker plumage.

The next day $\mathrm{H}$ — killed a fair male and female Granti and another hartebeest. I went into the bush on the south side of our camp, in the hopes of coming across buffilo, but though I saw some fresh tracks, I did not sight any of the beasts. I was lucky enough, howerer; to get a beautiful specimen of the lesser kudu (Strepsiceros Imberbis) with good symmetrical horns; a lucky shot hit him just before he galloped behind a bush, the bullet passing through the neck. These antelope are nearly as big as ordinary red-deer, of a grey colour, with eight or nine thin white stripes running down the flanks; they are not rery numerous in this part of Africa, and we did not see more than six or eight, and only shot two during the whole of our trip. Jackson told me they were plentiful on the coast near the banks of the Wami and Tana rivers, but that they always frequented thick bush.

About midnight, as there was a good moon, I took my post in the tree where a platform had been prepared, and there I sat and watched for the remainder of the night. But although I heard the frequent howls 
of hyænas and jackals, and the low growl of lions close by, no beast came to drink. I supposed they liad winded me and passed on to some of the pools lower down, so at daylight I descended from my crampeg position, feeling stiff and disappointed.

At Tareta we had engaged a Swahili elephanthunter, Kičaga by name, who professed to be an expert at tracking. He was a curious-looking creature of a dirty chocolate-colour, with his head clean-shaved and the skin puckered all orer his skull. He turned out to be a complete frand as a tracker, but proved useful as an interpreter, being one of the few with us who could speak the Masai language and other dialects which eren Martin did not understand. I took him out shooting with me after breakfast, as I intended to make my way to some bush about six miles off, on the north side of the plain near our camp. On the way I fired at a zebra without effect, and later on came across a small herd of buffalo in the bush about forty yards off, but while I was crawling round them to try and get sight of a good bull, they got my wind and suddenly dashed off without giving me any chance of a shot. On the way back I again saw oryx and tried to stalk them, but before I got within five hundred yards they took alarm, and after two or three bounds and a few defiant kicks of the heels in the air, galloped straight out of my sight. I also saw a very fine Granti a long way off, but being by this time pretty well tired, I left him alone. I was very glad to get back to camp at 5 P.M. after a tramp of eleven hours, following a mid- 
night vigil, especially as all I got for my hard work were two little gazelles, one of them smaller than a hare, belonging to the Kirkii. species, and the other a female steinbock. I found on my return that $\mathrm{H}$ had not fared much better, as his bag only consisted of two hartebeest.

The following day we returned to Taveta. On the way I saw a very fine giraffe bull, and tried for him, but could not get within range, as he never stopped striding along, and eventually I lost sight of him altogether. It is hopeless to expect to approach these animals on foot if they are moring, for, though appearing to travel very slowly, they cover a great deal of ground at every stride. I came across two good wart-hog near the forest, and had a shot at one, but missed disgracefully.

On returning to Taveta we found our nearly finished house presenting quite a palatial appearance. It consisted of three large rooms and a big courtyard, intended as a drying-yard for heads and skins of game. The roof was thatched and the interstices of the framework filled in with grass and Indian-corn stalks, while the walls were lined with red American sheeting, which excluded the dust, and at the same time admitted plenty of air. 'That night we dined and slept for the first time in our headquarter house, and gathered some of the early fruits of our garden, in the shape of mustard and cress, which had come up in an amazingly short time; the turnips, potatoes, radishes, peas, and beans had also begun to show, but there were no signs of the lettuces, onions, or celery. 
The evening was enlivened by one of our cook-boys, Kitembo, falling out with Kiboko, perhaps the strongest of all the men, the result being that Master Kitembo was nearly throttled before they were separated. Fights amongst the men were of frequent occurrence, but they never seemed to result in much damage to either party. Having no idea of using their full strength or of the science of hitting, the main object of the combatants always seemed to be to strangle one another. Kitembo had been one of Stanley's men on the Congo, and as he was a noisy quarrelsome fellow and very lazy, we determined to send him back to the coast, for up to the present he had only been a muisance.

The next day we left Taveta for Moči, to pay Mandara a visit; we travelled by the Caga track, the worst and hardest to follow of any of the paths leading out of the forest, and I could easily understand how I had lost my way in the dark on the former occasion; several awkward rivers have to be crossed by means of the most primitive bridges, made out of tree-trunks placed across the stream, with hand-rails of fragile palmbranches. As the story goes about these bridges, it appears that "once upon a time" the elders of Taveta were cudgelling their brains for some means of crossing the streams, without arriving at any result, when one smarter than the rest offered to solve the problem for the consideration of two bullocks. His request being acceded to, he soon settled the difficulty, to every one's satisfaction, by cutting down a few good-sized trees, so that they fell across the streams, and then fixing 
hand-rails of palm-branches alongside to steady the people in the act of crossing.

In about an hour's time we emerged from the forest; a march of about fifteen miles, in a north-west direction, first led us across a slightly sloping plain, and afterwards up the lower slopes of Kilima-njaro, which are freely intersected by watercourses discharging their contents, during the rainy season, into the river Lumi. One of these still contained some water, which about half-a-mile below the track disappears from riew in an underground passage, and we were unable to ascertain where it reappeared again: it must have been a very long distance off, as, although I afterwards shot all orer the plain below, I never came across any signs of it.

During the early part of the march we saw zebra, hartebeest, and numerous game-birds; later on we met a few of Mandara's men who were coming to see Martin, and bearing a letter for him, dictated by their chief and written by Mr. Fitch, a resident missionary at Moči. 'This letter stated that Mandara had heard we were going to pay a visit to Sina, chief of Kiboso, his sworn foe, and that he was much hurt at an old friend like Martin not haring come to see him first. 'These messengers, on hearing we were actually on our way to Mandara, joined our caravan.

We halted for the night in a little hollow near a small mountain strcam called Mto-abarri, and the camp, which was well shaded by magnificent trees, was pitched in the dry portion of the bed of this stream. Martin informed me that, often in the rainy season, 
torrents came down suddenly and unexpectedly, sweeping everything before them, and that he once lost two donkeys while crossing this very river. However, at that time of the year there was no fear of any sudden torrent, and the spot formed a delightful encampment.

$\mathrm{H}$ _ went out in the erening to look for buffalo, and was lucky enough to come across a herd of many hundreds close to the camp; after sereral shots he managed to secure a fine bull with ridespread horms, and it took four men to carry the head back to camp. The heads of these African buffalo are splendid ; the largest we got during our trip measured fortyfour inches between the horms at the widest place. In a well-grown bull these horns almost meet across the forehead in a rough and massive frontlet some fifteen inches wide, and extending outwards, with a graceful sweep, taper gradually to sharp points which curve inwards and slightly forwards. 'The young bulls have incomplete frontlets, the middle being soft and sometimes for a space of three to five inches corered with hair instead of horn. A full-sized bull is about twice as heary as an English domestic ox, and the coat is usually a dull grey colour, due to loss of hair. The young bulls have sleek coats of black and glossy hair. Of all the animals hunted during our trip, the buffalo is probably the most cunning and dangerous to attack; they become rery sarage when wounded, and usually take to the thick bush, where they lie in wait for their foe. 'The greatest care should be taken in following them up, as, on account of the denseness of the bush, 
it is next to impossible for the hunter to aroid the sudden charge that is almost sure to ensue if the buffilo sights him first, and he will find no time to get in a shot. In the open plain the danger is reduced to a minimum, as a reliable eight-bore rifle will stop any buffalo-charge. I am supported in this opinion by Mr. Selous in his most interesting and instructive narrative of "A Hunter's Wandering in Africa," and also by Mr. 'Thomson, who describes in his equally attractive book, "Through Masai Land," how he was tossed and nearly killed by one of these brutes. I recollect sceing a Swahili porter who had survived the attack of a buffalo, but his face was so smashed that it was difficult to discover where his mouth began or ended, and his nose and eyes were all mixed up together in the most hopeless confusion.

II___ said the men with him quite lost their heads with excitement when he knocked over his first buffalo, and fired their carbines into the ground and into the beast's quarters until they had peppered it all over.

We started early next moming, and reached Mandara's dominions in about five hours after an uphill march of about fifteen miles. On the way we obtained splendid views of the forest of Kahe and the surrounding plain and bush, stretching for miles to the south, bordered on the east side by the Pari mountains, and on the west by a high range called the Soghonoi, inhabited by the I"'Arusha: beyond, we sighted for the first time the high and pointed peak of Meru, a 



\section{PLATE II.}

No. I. Rhinoeeros eow (Rhinoceros bicornis), shot near Useri; length of horns, front 23 inches, back 22 inches.

No. 2. Rhinoceros bull (Rhinoceros bicornis), shot between Rhombu Camp and Useri ; length of horns, front 27 inehes, back 12 inches.

No. 3. Brindled wildebeest bull (Connochetes gnu), shot near Rhombu Camp; measurement of horns between the tips 16 inehes, inside the bend at the widest $2 S$ inehes.

No. 4. Wart-hog (Phacocharus athiopicus), shot near the Mto-Abarri.

No. 5. Horns of the three-liorned rhinoeeros on a strip of skin; length of horis, front 10 , middle 6, baek 3 inehes.

No. 6. Buffalo bull (Bubulus eaffer), shot near the Weriweri river; mensurement of horns between the tips 21 inches, inside the bend at the widest 36 inehes, depth of frontlet I4 inelies. 

lofty and isolated mountain in the Masai country, to which we hoped later on to pay a risit. We fell in with zebra and hartebeest, apparently very tame, and also water-buck. I might have shot one of the last near a stream we crossed, only some of the men saicl they had seen a herd of buffalo a little lower down the hill, so I preferred to go after them without risking the cliance of their being disturbed by a rifle-shot. However, I might just as well have bagged my waterbuck "in the hand," as, though I went nearly to the foot of the hill, all the buffalo had retired to the bush, and I did not even catch a glimpse of them.

On my return to the caravan I found Martin in a great state of mind at my having gone off with only one man, because he had seen a large body of natives in the plain below, and was afraid they might prove to be a Masai war-party, who generally frequent this route on their way to the coast. The last two hours led us up a steep ascent through thick bush until we eventually arrived at the entrance to Mandara's dominions, a rough sort of gate like the one leading into Taveta, and here our men fired the customary salute, which was replied to by the natives inside.

After crawling through the narrow gateway we had to cross a very steep ravine ending in a narrow stream, and on ascending its opposite side we soon arrived at a camping-ground set apart for strangers. Unfortnnately we found the house Martin had built here, during a former visit, occupied by some Swahili slavetraders and in a filthy state, so we had to be satis- 
fied with using our tcnts. Of course, the natives on our arrival collected in large numbers, and brought a message from Mandara, stating he was some way farther up the mountain, but would come down to receive us later on in the day at a shed just below our cncampment where he was in the habit of giving audience to his visitors.

Mandara formerly lived on the spot occuped by this shed, which is 4000 fect above the sea; but since the Wa-kiboso attacked him about six months previously, when he only just escaped with his life, he laad preferred living another thousand feet higher up, for greater security, where he occupied a house made of galvanised iron which he obtained from the missionaries. We made ourselves as comfortable as we could, and awaited with some intcrest the arrival of the cleverest and most enlightened savage chief, the swaggering bully of all these parts. 


\section{CHAPTER $\mathrm{X}$.}

Mr. Fitch, the missionary-Our reception by Mandara-His habits and diplomacy-His allies and warriors.

Before Mandara arrived, Mr. Fitch the missionary, a very agreeable man, paid us a visit. Having lived here for the last two years, he had just finished building himself a small house higher up, near the site of $\mathrm{Mr}$. Johnston's encampment when the latter spent some months exploiting the mountain, and close to where Mandara had set up his iron dwelling. The missionary seemed rather in awe of Mandara, and probably not without good reason, for he appeared to have bullied and worried him a good deal at times, and Mr. Fitch told us how, when Mandara was out of temper, he had cut off his supplies and regularly "boycotted" him by forbidding the people to sell him any food or to assist him in buikling his house. The worst moments of the chief occurred when the pomber ran short, and as the previous year had been a very bad one for bananas and mtana, out of which his farourite drink is manufactured, he had in consequence proved particularly disagreeable. During the present year, however, there was plenty of pombé, and he had been in capital humour and much more friendly. Mr. Fitch declared it was not customary for Mandara to receive visitors 
later than two o'clock, as after that hour he was generally too drunk to transact any business, so I suppose we were especially honoured by his keeping sober enough to receive us on this occasion.

At about two o'clock the great man came down, and sent word to say that he was graciously willing to grant us an interview, and we at once proceeded to his audience-chamber, accompanied by Mr. Fitch, Martin, and some of our head-men. In a large shed, furnished with a rickety table and two still more rickety chairs, we found Mandara seated in front of a bottle of his favourite pombé. He received us in a dignified manner, and was very agreeable, but seemed much exercised about Martin having paid his enemy, Sina, a visit on the occasion when he came up with General Mathews to hoist the Sultan's flag in order to forestall the Germans who were intending to annex territory in the neighbourhood of Ixilima-njaro. He had been excessively augry about this visit, and had even threatened to cut Martin's throat, as he considered it very wrong of him, after having become a blood-brother, to enter upon friendly negotiations with a foe.

'This subject formed the whole topic of conversation during our long interview, at which Martin explained how it was no fault of his, seeing he was bound to go wherever his employers chose to take him, and after a long argument he appeared to be forgiven. I was surprised that our host displayed so little curiosity about us, and made no reference to the all-important question of homgo. 
Mandara is a very fine specimen of the black savage, big and well-proportioned, though rather inclined to be fat. His height is about six feet, and a broad and not ill-natured countenance displays signs of much intelligence, though its beauty is somewhat impaired by the loss of one eye ; but the sharpness and cunning of the other gave me the impression he could see as far through most things as any other native with two. He was dressed simply in a loose robe of American sheeting dyed light red, and only wore a few ornaments in the way of necklaces and ear-rings; but he was crowned with an old shooting-cap about three sizes too small, which, however comical in effect to us, was doubtless a fitting emblem of royalty to his subjects. Having made it all up with Martin, he became quite checrful, laughing, chatting, and expectorating, in evidence of thorough good-humour. I was told that when he was in one of his "moods" he hardly noticed visitors, but kept up an animated conversation with his personal suite. After" an hour's interview we bade him "goodbye," and departed with the promise of his return visit next day. During the afternoon he sent us a present of a white goat, and Martin went round to convey our personal thanks, but discovered he was suffering from the full effect of his farourite pombé.

Mr. Fitch returned with us to our camp, and I had a long conversation with him, during which I learnt a good many interesting facts about the people of Moči and their chief. Mandara has a great opinion of his importance, and is somewhat tyrannical with his own

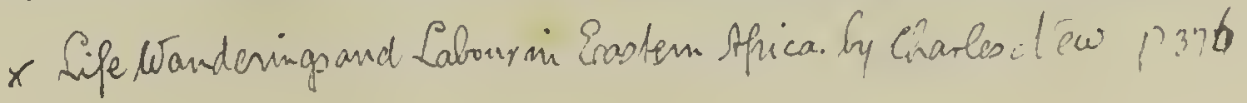


people, in addition to being a regular bully of the whole mountain-side. He is much respected and feared by his subjects, who call him "King," and acknowledge the divine origin of that title to the extent of believing "the King can do no wroug." He apparently acts liberally towards them, and, for a sarage, rules with justice. The secret of his power does not lie so much in the numbers of his own warriors as in those of his allies, for though he told us he possessed a thousand of the former, I believe in reality five hundred would be nearer the amount he could find available for active service.

'There are several neighbouring' tribes far larger and more powerful in point of numbers, any one of which could easily wipe him out if it were only a question of tribe against tribe. But Mandara is quite clcver enough to realise this, and being a first-class diplomat, employs all his skill and cumning in kceping on friendly terms with certain neighbours, who by particular terms of alliance are bound to help him against any hostile attacks, and in the numcrous expeditions he organises against his foes. IIe also intrigues with the view to fomenting feuds among all who are not in his actual alliance, thus preventing any combination en masse. against him; and he further takes care that his own allies shall not be on over-friendly terms with cach other, lest their "too good understanding" may turn out to his disadvantage. His chief supporters during our time wcre the IV'Arusha, a powerful and unscrupulous tribe, supposed to be a degenerate race of the 
Masai, who inhabit the country south of the Sogonoi range of mountains and around Mount Meru. He had also enrolled the Wa-mačame, a strong people occupying the south-rest slopes of Kilima-njaro, and the Wa-marāmu, ruled by Chief Miriale, his next-door neighbours on the east side. Besides these, most of the small tribes had been enlisted as mercenaries under pain of having some of the more powerful allies set at them in the event of any failure to obey his commands.

Thus, by his intrigues, superior intelligence, and swaggering bounce, Mandara had managed to set the country by the ears, and was, to a considerable extent, the practical ruler of the whole mountain-side-a singular instance in savage life of the triumph of intellect over brute force. His great enemy and rival is Sina, chief of the Wa-kiboso, a tribe on the western border of his dominion, and in numbers probably the most powerful of all. Sina holds an almost impregnable position, and is a sharp thorn in Mandara's side, who lives in constant dread of his attacks. Only a few months before our visit, he was one morning surprised by a Kiboso raiding-party and suffered severe losses, for his house was burnt, all his treasures looted, and he only managed to save his own skin by flying to the bush. But when his men had collected, they waylaid the victorious Wa-kiboso on their return home, and retaliated by killing a considerable number. Since this loss of property Mandara has slept higher up the mountain, and built the iron hut for his greater protection, in addition to employing a strong bodyguard 
and posting scouts in all directions to give timely notice of any attack. With the assistance of the $\mathrm{Wa}$ macame on the other side of the Kiboso and the IV'Arusha below, he is now able to keep Sina fairly in check and to hold his own.

Mandara has many wives, aged from fourteen years upwards, and when he gets tired of a few, passes them over in marriage to his head men. I asked Mr. Fitch whether the head men approved of this mark of royal favour, and he declared they were perfectly satisfied, as the present of a wife was always accompanied by the additional gift of one or two cows. His method of punishing an offending subject is somewhat arbitrary, though very simple. On any provocation, howerer slight, he orders some of his people to seize the offender's' cattle and plantation and divide everything amongst themselves; this the greedy simpletons readily do, without considering how soon it may be their turn to be treated in the same manner.

There are always a certain number of naturalised natives of other tribes living in Moči, for whenever a young and able-bodied man wishes to become a settler, it is only necessary that he should bring Mandara a present of pombé and proffer a request to become one of his subjects; thereupon he receives an order to seize the plantation of some old man who is commanded by "royal letters patent" to clear out and make room for the younger and more useful warrior. These pleasant little ways of Mandara cause him to be much feared, and it was amusing to see how the crowd of natives, who at 
other times filled our camp, melted when he was reported to be on his way to pay us a visit. Whenever his stock of cattle required replenishing, he and his allies would combine in a raid on some wretched tribe too weak to offer any opposition. The poor Ughono (Ugweno?) people, who live in the Pari mountains, are as a rule the rictims; these unhappy natives, as I have before said, seem especially created for the sole purpose of enriching their more powerful neighbours.

Naturally Mandara has not attained to his present position without becoming proportionately conceited; he considers himself the greatest man in the world, and had the impudence, or naiveté, to ask Mr. Fitch "if he really thought the German nation could turn him out had they a mind to do so !"

The natives are generally of a lighter complexion than most of the Wa-taveta, their colour varying from dark to very light brown, and they are also of finer physique. The dress and adolnment is very similar, an important difference being that the unmarried girls wear a small tassel of beads, about the size of a folded pocket-handkerchief, instead of a petticoat. Some of the men have good features, and niany of the women are well-shaped and almost nice-looking. All appeared simple-minded though inquisitive, were never troublesome, and neither bothered us for presents nor attempted to steal. 'They acted as though they were thoroughly well-disposed towards us, but I suspect I might have told a different tale had Mandara not received us as cordially as he did. 
The men, unlike the Wa-taveta, aroid the most primitive form of clothing, and the small piece of cloth, hung on the shoulder, is worn for ornament and not for covering. On their ankles little rattles, consisting of thin strips of leather, to which are attached curiously wrought and hollow bits of iron, make a tinkling noise when the wearer moves; these are de rigeur, and any one caught after dark without them is treated as a thief. The weapons were superior to any we had yet seen, and a large number carried muzzle-loaders in addition to their big spears. Mandara presents to each of his head men a long spear, the facsimile of that used by the Masai; the blades of these formidable weapons are broad and flat, and vary from eighteen inches to two and a half feet in length; the shafts consist of about one foot of hard wood and three to four feet of solid iron pointed at the lower extremity. All the Caga tribes are the blacksmiths of the country, but the chief are the Wa-moči, and Mandara has a great personal reputation for being a clever armourer; it is for this reason that he is on friendly terms with the Masai, who pay him frequent risits to obtain spears and honey in return for cattle.

The iron heads and shafts of the spears are all manufactured out of trade wire, which is wonderfully wrought and welded together by native skill. From the same material they also manufacture fine chains, for use as ornaments, by a process which is rather laborious though ingenious. One man has to draw ont the thick wire into fine threarls by passing it while red-hot through a series 
of small holes in an iron plate, the wire being each time forced through a smaller hole than the last, until it is drawn out into lengths of the requisite calibre, and in this state wound round a very thin iron rod; another then proceeds to cut through each coil, thus forming a number of fine and small rings, which a third welds together and hammers into links of the necessary shape, the result being a really fine-wrought chain, afterwards employed for ear-rings or necklaces, or for the adornment of snuff-boxes. We asked Mandara to make us some spears, and he promised to do so if we sent him enough wire for the purpose, but he never fulfilled his promise. The warrior's are further equipped with large oval shields of buffalo hide, short swords, knives, and "knob-kerries" of hard wood or rhinoceros horn.

Here, in contrast to other places, the women were not allowed to loiter about the camp, especially if Mandara or his head-men were about; even when they brought us bananas, \&c., they only stopped long enough to deposit their loads and then left as quickly as they could. I noticed on our arrival a crowd of women watching us with apparent curiosity, but they retired precipitately on our nearer approach, and I afterwards learned that these were mostly wives of Mandara who beat some of them sererely when he was told of their curiosity, and inquired "why they wanted to look at the white men." 


\section{CHAPTER XI.}

Religious and matrimonial ceremonies of the Wa-moči-Customs and superstitions-Physical features of the conntry-Mandara's presents -Photographic efforts-Mandara's return visit-The lion-trapReflections.

The Wa-moči, like the Wa-taveta, pray to the sun and moon, and believe in the spirits of their parents, whose bodies they bury immediately after death, but later on dig up and scatter the bones under the bananatrees. When ill they pray to these ancestral spirits, imploring them to send back health and strength. Crime is very rare among this tribe, and a murderer generally takes refuge, with a hostile neighbour, to aroid the penalty of death or a heary fine of cows. A convicted thief is either condemned to die or to have his right hand cut off.

The preliminaries to what we consider the holy estate of matrimony are, among the Wa-moěi, full of theatrical absurdities and savagery. 'The young man, having cast "sheep's eyes" at the damsel of his fancy for some months, enlists the service of four friends who are deputed "to go and catch her." The lady is sure to make some decent show of resistance, for this is her leading part in the theatrical programme, but she is eventually carricd off in triumph, each 
captor holding on to a leg or an arm. This represents the first act in the comedy. During the second act she is rubbed over with grease, and confined in an empty hut, without food, for twenty-four hours, while the intending bridegroom enters upon a spirited bargain with the parents until her precise value in cattle is arranged. Directly the beasts are paid orer, the marriage is legally settled, and the third act introduces the reward of the four faithful abductors, too barbaric and immoral in character to admit of any detailed description. Throughout all the tribes in this part of the country the first three acts of a marriage ceremony rary but slightly with those I have just described; but as couples are not securely united until after a lapse of four months (for at any time within that period the husband may, if disappointed with his bargain, return the bride to her sorrowing parents, and receive back in exchange all the cattle he paid for her), the fourth act does not take place until after that period of probation. Then a big feast and a drunken carouse, to which all the husband's friends are invited, is evidence that the marriage in question has proved to be "no failure." Finally, "free love" is an understood thing, and the wife is allowed to take to herself as many lovers as she may choose, provided each pays her lawful spouse an indemnity.

The Wa-moči have a strong belief in omens, and especially in those-provided by the entrails of goats and bullocks. Mandara is held in high repute as a 
great soothsayer, medicine-man, and specialist in all the lore comnected with animal's "innards."

The war-cry of the Wa-moči is Wōmé, W'ome (Men! Men!), and should any sudden attack of an enemy be apprehended, this cry brings the warriors down from their mountain homes with all celerity. They prefer to eat meat raw, but Mandara is particular and insists upon having lis own meals cooked. The dwellings are beehive huts, made from the leaves of bananatrees. All cattle are similarly housed and only allowed to graze for a short time on the slopes; the women are therefore constantly employed in cutting grass for them. Should a woman give birth to twins, the national law requires only the sacrifice of one infant; but should a cow or a goat meet with the like misfortune, mother and offspring are at once put to death.

The country of Moěi consists of a series of steep and well-watered ravines, the inclines of which are dotted with cultivated plots and clumps of bush; the inlabited parts are hemmed in and protected below by thick bush, and above by the almost impenetrable fringe of the mountain forest. The soil, like that of Tareta, is rich and fertile, yielding all kinds of native produce in addition to providing pasturage for numberless sheep, goats, and cattle. Excellent milk can always be obtained, as well as honey, for here is a land literally overflowing with both; the domestic forv is extinct, having become a victim to the same famine that devastated the Teita district about a year previous to our visit. 
We had pitched our camp in the open place set apart for strangers, on a slight incline, embracing a splendid view of the plain and the inhabited forest of Kahé, which, stretching southward for some miles, is bounded east and west by the distant mountain ranges of Ughono (Ugweno?) and Sogonoi. Above, and on either side, rise the gently sloping gradients of the mountain, in some places green with fresh grass, and in others with dense bush here and there relieved by the bright emerald-green tops of banana-trees, the whole being intersected by the narrow and tortuous paths leading to the various plantations. Still higher up, on a clear day, can be seen the steeper slopes of Kilimanjaro, clothed with a forest of magnificent timber, and abore all towers the snow-capped dome of grand old Kibo.

The climate is delightful; the sun is not too oppressive, and a fresh breeze is usual rather than exceptional. Sudden thunderstorms and downpours are, however, by no means rare, especially in the rainy season, and during our short stay we were treated to some very fair samples of both, though we visited the district during what are considered the "dry months."

We called upon Mandara the following morning, and presented him with a clock that struck the hours and half-hours, a revolver, and a load of fancy-coloured cloth, the whole gift amounting to about twenty pounds English value. He showed no sign of satisfaction, and made no remark beyond complaining that the clock did 
not strike loud enough; but from the twinkle in his eye I concluded he was fairly well pleased, though of course not satisfied, such a condition of mind being abnormal with him. He was in excellent humour, and we had a long conversation, during which I was much impressed by the shrewdness of some of his questions and remarks, which showed a great deal more knowledge than popular report credited him with. This perhaps is to be accounted for, to a certain extent, by his having come into frequent contact with the Swahilis during their negotiations in ivory and slaves, which involve a fair amount of profitable business. We sounded him about Mr. Thomson and Mr. H. H. Johnston. The former, he said, he liked very much, and charged us with a message to him to that effect; but against the latter he exhibited an exceptional animus, and was anything but flattering in his remarks. He admitted a great respect for Sir John Kirk, but evidently did not think much of the reigning Sultan.

I tried to persuade him to let me take his photograph by telling him that every one had his likeness taken in England; this made him immediately ask " if the Queen had ever been photographed." I said, "Yes; for her subjects were all proud of her, and insisted upon having her portrait;" but such was his dread of possible magic that I could only get him to promise "lie would think about it." When we rose to take leave he called Martin back and asked him "how it was, having come with a recommendation from the English Consul, we had only given lim such a little prescut?" to which 
Martin replied with commendable tact, "that if he treated us well we should probably give him something more." Martin informed us that it was the invariable custom of this greedy savage to appear dissatisfied with any present, however magnificent.

On our return to camp I made great efforts to photograph some of the natives, but it was a most difficult job, as the moment they discovered my intention they bolted. However, I succeeded in taking some of them unarwares. The instantaneous shutter was an especial object of dread, being held to be charged with strong magic; but whenever I had performed successfully upon an unsuspecting group, all who had watched the operation screamed with delight, and declared "I had circumcised them."

Mandara sent us a present of a bullock and bananas sufficient to feed the men for two days, and during the afternoon paid a risit to our camp. He has a peculiar habit of whistling softly to himself whenerer a sudden thought strikes him or whenever he is surprised at, or wants, anything in particular. On this occasion he inspected all our belongings most minutely and with an ominous amount of whistling. We gave him an old shooting-cap, a red woollen nightcap and a red silk cummerbund, while he puffed away with evident appreciation at a cigarette we handed him, and declared he would send to England for a supply! I referred again to the subject of taking his portrait, but he only replied that "he was not used to it yet." Forthwith he pulled three of his men out of the crowd of natives forming a 
ring round our tent, and ordered them to stand up and be photographed at once. This the poor wretches did, looking half-dead with fright, but not daring to disobey. Directly they were focussed I called Mandara and showed him their pictures on the image-glass. This pleased him immensely ; but still greater was his delight when I let him take the actual photograph by squeezing the indiarubber-ball of the instantaneous apparatus, and when he understood the deed was accomplished he danced about, and thumping me on the back bellowed for fire minutes. I believe he thought he had done the subjects some awful injury, and that notion tickled him greatly. When I remored the instantaneous shutter, and held it up to explain its rorking, he took fright, and rumning away, like a whipped cur, hid behind some of his own people in a most undignified manner, and it was a long time before he was sufficiently reassured to re-enter our tent. When at length he came back he wanted to see some specimens of photographs, and $\mathrm{H}$ — produced a few, which he silently and minutely examined, and then exclaimed in admiration, "What cunning fools you are!" an expression we were intended to accept as a compliment. He asked the price of the camera, and when I told him that it had cost as much cloth as would represent fifty pounds of English money, he bluntly replied, "You are a liar!"

The lion-traps particularly enchanted him, and he made us promise to give him one before we left the country, as he complained of the place being nutuch 
infested by leopards, which had become bold enough to kill some of his women by springing at their throats while they were in the act of cutting grass for the cows. He declared that only a few days ago he had tied one native up as bait and posted another in hiding with a gun to shoot the beast when it came; the only result from this manœurre was that the leopard lilled the human bait and was clean missed by the sportsman in ambush.

$\mathrm{H}$ — paid Mandara a second visit after the rest of us had left the country, and made him a present of the coreted lion-trap. I have subsequently heard the brute never attempted to catch any leopards with it, but merely amused himself by haring it set, and forcing some of his old wives to walk into it and letting the poor wretches remain in its powerful grip for several hours. I believe Mr. Rider Haggard has enlarged upon this iniquity in "Maiwa's Revenge."

We asked Mandara to give us a milch cow ; so, after seeing everything we had to show, and getting all we intended to give, he led the way with great solemnity and introduced us to the creature he proposed lending us, on condition we returned her to him when the milksupply was exhausted. We could have done equally well without this particular cow, as she nerer yielded one single drop of mills from the day we receired her.

Having disposed of Mandara for the present, we climbed with Mr. Fitch up to his house at Kitimberiu, about two miles off, and a thousand fect higher up the mountain. We found a comfortable little two-roomed 
house, built of mud, with a banana-leaf thatch, shaded by a cool verandah. He had only just managed to complete the building, as during his first year of residence, what with the famine and the consequent scarcity of pombé, Mandara, having made himself as unpleasant as he well knew how, had constantly forbidden his people to assist the young missionary. He shorred us quite a collection of mative decorations and curiosities, and very kindly gave me three little ornamented horn snuffboxes, the complete costume of an unmarried girl in the shape of a bead tassel, and a solid brass neck-ring looted in a raid against the Wa-ughono (Ugweno?); to obtain this prize, the victor, a Moči warrior, had found it necessary to cut off the head of its unfortunate owner.

After a short rest, having admired the splendid riew of Mount Meru in the far west, and refreshed ourselves with excellent coffee, most acceptable after our stiff climb, we returned to the camp by a steeper and less circuitous route, to find that Mandara had sent word during our absence that he had collected all his wives together to be photographed. Unfortunately it was then too late for me to take advantage of his kind condescension. In the evening Mr. Fitch thoughtfully sent us down a most welcome supply of fresh bread, for though we had brought out a small field-oven, our Indian cook never seemed able to turn out anything but the flour pancakes yclept chupatees. A typical specimen of the disreputable mission conrert brought the gift, and was half-drunk when he arrived. His 
knowledge of English found its only expression in a request for whisky, intermingled with a string of oaths, and we had some difficulty in getting rid of him. When he did take his leare he expressed a hope we should come again soon and bring lots of whisky, "as he could not get any at the mission station, which was a $d-d$ shame."

The only fauma of interest we observed at Moči were white lavens and green pigeons, both, I believe, peculiar to the mountain. The former have a ring of pure white feather's round the neck, and a similar white patch on the back, the rest of the plumage being jet black. The colour of the pigeons is a dark green.

The following morning we bade good-bye to Mandara, whom we found sitting in the midst of rows of wives and looking rather "chippy" after his heavy over-night potations; we parted with professions of mutual friendship, and marched back to Mto-abarri. So ended our visit to this notability, in every way satisfactory and decidedly interesting, though as far as its main object was concerned, in my opinion, quite unnecessary. I do not think that he had the power, even if he wished, to annoy us very much in the plains where we intended to do most of our shooting, so there was no real necessity to conciliate him. However, apart from the loss of five days, no harm was done by the visit, and perhaps it was as well to be on the safe side. Personally I was rery pleased at the opportunity of meeting the man of whose exaggerated power and importance I had read and heard so much. 


\section{CHAP'TER XII.}

My first rlinoceros-Eland-Arrival of C.-A trip to Lake JipéMpallah and water-buck-A good haul of fish-Return to Taveta.

'THe day after leaving Moči, H- returned with the caravan to Taveta, while I descended to the plain, intending to shoot my way leisurely back. Having crossed an open expanse clothed with thick dry grass, I saw a distant herd of eland, and at once began a careful stalk. During a short rest I glanced back and espied a fine rhinoceros cow with a half-grown calf coming down the lill in my direction, so at once giving up the eland and noting the line taken by the rhinos, I ran quickly back to intercept them. I happened to hit off the right place to a nicety, and managed to get up to a small bush just as they were passing by within fifty yards, and was in time to plant a solid bullet from my $577^{\circ}$ rifle behind the shoulder of the cow. It evidently struck hard, as she stopped short, gave one snort, and then dashed off at a right angle. Uncertain whether she was mortally wounded or not. I gave her my second barrel; but the first had done its work, as after running at full speed for some two hundred yards she again stopped, gave one final totter, and fell dead. The half-grown calf, about the size of a small bullock, stood by her side, showing signs of fight 
and would not let me approach; so I had, in self-defence, though not without reluctance, to shoot it.

This introduction to rhino made me feel very satisfied with myself, and I confess to great elation as I regarded the larger carcass, which from a short distance looked like a mound of brown earth four to five feet in height. From it my men hewed off the fore-feet and horns, and then removed the head of the calf, whose sprouting horns proved it to be about two years old. The skin of the mother was in a bad condition, and covered with sores common to her kind during the dry season, but the horns were very fair specimens. Before shooting, I noticed several rhinoceros-birds perched on her back and head, and it was curious to witness their almost ludicrous efforts at balancing when she broke into a lumbering gallop. These birds, of a light-brown colour, are rather larger than thrushes, and feed upon the numerous parasites which infest the hides of all rhino, so they may be considered as welcome attendants.

I decided to send a fatigue party from Taveta the following day to bring in the meat; so, having seen the trophies securely lodged in a neighbouring tree, I continued my journey. Very soon I viewed a number of eland feeding slowly down a slope torrards me, but they showed signs of having sighted me first and stopped short. Feeling sure that any advance would have to be made by me, I proceeded to stalk them, and after a slow and tedious crawl of about four hundred yards through the long coarse grass, managed to get 
within a hundred and fifty yards of the herd. I could not venture any farther without risk of being scen, so, selecting the best-looking cow-there being no bull-I fired. Her shoulder was broken by the shot, but she led me a long way, before I secured her, by moving slowly forward whenever I was almost within range.

The eland is a large animal, standing high, with a slight hump on the withers, and has a dewlap depending from the breast, to which is attached a tuft of long hair. The lower part of the body is grey, while the upper portion is reddish-brown, intersected by a few faint white stripes. Some of the old bulls are of a light bluish-grey all over, and have very thick horns, a distinct contrast to those of the cow, which are usually thin and delicately tapered. Those of the largest bull we killed measured twenty-cight inches, and those of the largest cow about thirty inches, but I behieve they attain to greater length in other parts of Africa; they are twisted in their longer axis, and diverge with a backward incline. While in pursuit of the wounded eland my men reported another rhino, and I immediately followed their lead, but only to reach a point from which I could see a monster black mass plonghing its way at a tremendous pace across the plain, in an opposite direction to myself. It must have passed the carcasses we had left, and then ascending the hill, for a short distance, got our wind. It is astonishing what a pace these clumsy-looking animals can go when startled, and this one, as he careered along, at the rate of about 

PLATE III.

No. I. Eland bull (Orcas canna o), shot near the Mto-Abarri river; length of horms from base to tip 24 inehes, widtb between the tips 12 inehes.

No 2. Eland eow (Orcas canna 9 ), shot outside the forest of Taveta; length of horns from base to tip 27 inehes, width between the tips ro inches.

No. 3. Walleri buek (Gazclla Walleri), shot near Lake Jipé; length of homs along the bend 14 inehes, width between the tips 3 inehes.

No. 4. Oryx-beisa bull (Oryx beisa), shot to the south of Lake Jipé; length of horns from base to tip 29 inehes and 30 inches respeetively, wilth between the tips 10 inehes.

No. 5. Steinboek male (Nanstragus tragulus), shot near Taveta ; length of horns 5 inches, width betreen the tips $2 \frac{1}{2}$ inches. 


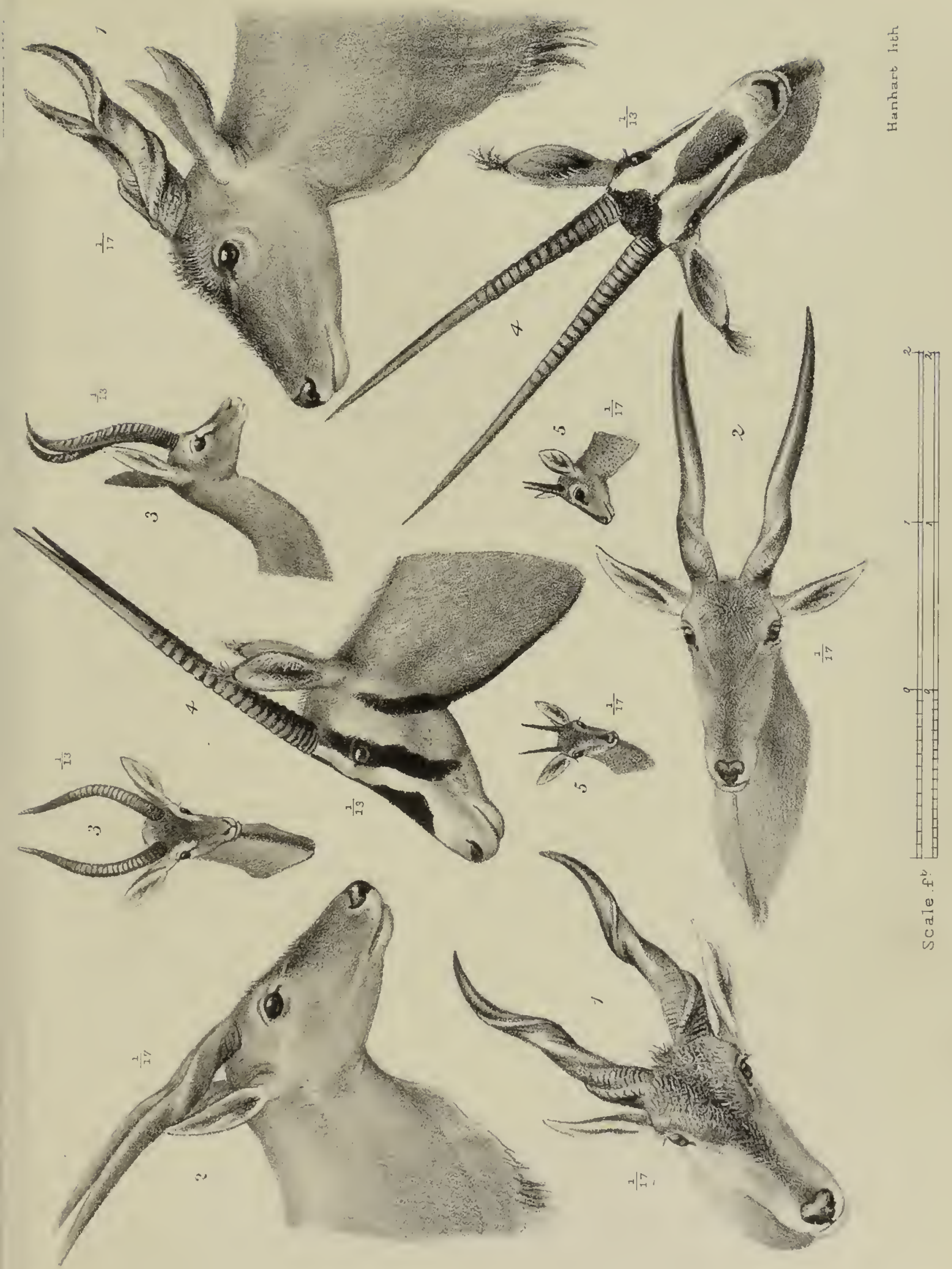



twenty miles an hour, vividly recalled the recollection of a locomotive steam-engine.

Having cut up the eland, I started for 'Tareta well laden with meat, and arrived in camp at 4 P.M., tired and thirsty, after having been obliged to share the contents of my water-bottle with the men, who had filled all their calabashes with a supply of honey purchased at Moči.

I found $\mathrm{B}-$ and Jackson just returned with $\mathrm{C}$ - who had arrived at Taveta two days before, and joined the others at Rhombu. C- had killed a rhino, a zebra, a hartebeest, and a giratfe on the march up. B- in twelve days had killed four rhinos, one ostrich, and several antelope, while Jackson had also secured four rhinos, in addition to other game.

The arrival of the mail, bringing our first batch of. letters and papers from home, was soon announced, all complaining of miserable weather and much snow-news which made us congratulate ourselves on being where we were. Our party was at last complete, and with Jackson as a guest, we sat down to a cheery dinner, the pièce-de-resistance being young rhinoceros-steaks, which were voted excellent. 'The next day we despatched forty men to bring home the meat of the animals I had killed : they found the big rhino intact, but the young one and the remains of the eland had been devoured during the night by hyæenas and jackals.

$\mathrm{H}$ - and I having hitherto been unable to explore the shores of Lake Jipé, we all decided to pay them a visit for a few days before starting on a longer trip, as 
large quantities of game were reported to frequent that district during the season when the regetation of the surrounding plains was dried up. With this trip in view we only remained at 'Taveta two days, which were fully occupied in preparing our trophies, any surplus time being filled up by attending to the garden.

First we each selected five men to act as gun-bearers, and then, after completing all other necessary arrangements, $\mathrm{H} \longrightarrow$ and $\mathrm{C}-$, with the caravan of nimety men, started for Lanjora, where B- and Jackson joined them late in the afternoon. On the road Cshot a steinbock, and $\mathrm{H}-$ got a hartebeest, a jackal, a mongoose, a spur-fowl, and a thick snake about four feet long. $\mathrm{B}-$, marching with me, shot a spur-fowl, a partridge, and a lesser bustard; so the day resulted in a mixed bag of eight varieties, such as they were.

The following moming we marched about fifteen miles through the bush, till we found a suitable campingground near the east shore of Lake Jipé, which on this side is hidden from view by a wide belt of tall rushes and clumps of mimosa. During the journey $\mathrm{H}$ shot a reed-buck, a bright red antelope about the size of a chamois with similarly shaped horns, and $\mathrm{C}-$ brought down a fair specimen of mpallah, which is common in these parts and always to be found in bush bordering pools or springs of water. They are reddishbrown in colour, about the size of fallow deer, and have graceful widespread horns. I had to carry the gun "for the pot," and my bag ouly consisted of a brace 
of partridges, a spur-fowl, and a small plorer; but I saw several beautiful golden-crested cranes, numerous parrots, and other birds of gay plumage. Our camp for the night was pitched about a hundred yards from the edge of the lake, which could here only be approached by a narrow hippopotamus track through the reeds; the water was muddy, green, and slimy, and notwithstanding any amount of boiling and filtering, most disagreeable.

During the afternoon we searched the country in different directions, and I made straight for a low hill north-east of the lake. In my ramble I saw female mpallah, water-buck, and any amount of Kirkii, which were running about as thick as rabbits in a warren. I also sighted two lions which had just left the carcass of a mpallah they had killed; unluckily they were two hundred yards off when I caught sight of them snealing into the bush, and at that distance were hardly worth a shot; nevertheless I did fire, but without success. They immediately disappeared in the covert, and, though I took up their tracks for some distance, I failed to get another sight of them. From the top of a small hill I obtained an extensive view of the vast plain below with its thick bush beyond, and on my return came across a fine water-buck, near the lake, which I knocked over. He got on his legs quickly and made for the bush, and as it was getting dark I lost him, but I recovered him the next morning, being drawn to the spot by the vultures hovering in the air. 'The waterbuck (Swahili Kuru) is an antelope somewhat larger 
than a red decr, with a close shaggy coat of coarse grey hair, and with thick annulated horns sweeping gracefully backwards.

I found on my return to camp that $\mathrm{C}$ - had killed four mpallah and one Kirkii ; II- had fired at four lions without effect, and had scen several alligators on the shore of the lake.

We all went out the next day, but returned with histories of disappointment. I had shot a few guineafowl, when the men said they saw two rhinos, but I never got up to them although I travelled a long way in the direction they were declared to be taking. $\mathrm{B}$ - carried his explorations some twelve miles to the south, and wounded a hippopotamus which immediately disappeared from view, while $\mathrm{H}-$ only secured one mpallah and a hartebeest. As the game, therefore, did not appear to be over-plentiful in these parts, we decided to waste no more time, but to return to Taveta and arrange a hunting expedition in another direction.

In the evening we caught, on the lake, with our Seine net, sereral hundred fish of various linds, the largest being silurians, averaging from five to seven lbs. These hauls came in handy at that time, as fish are much appreciated by the Swahilis, and the Ughono (Ugweno?) people, who had promised to supply us with food, never turned up-a matter of no smrprise, as we afterwards found they lived in the mountains on the opposite side, a good day's journey off. Had we proceeded another fifteen miles south we should have found any amount 
of game, for $\mathrm{C}$ - and I later on made a trip to those parts, and had excellent and raried sport.

The others next day returned by Lanjora, but I determined to go straight for Taveta instead of making the wide detour. Notwithstanding the assurance of my men that there was no road, after separating from the party at the head of the lake I soon struck a path leading direct to Taveta, which I afterwards discovered to be the proper Pangani road, though cararans coming inland usually make the detour by way of Lanjora. By taking this route I got to headquarter's after a five and a half hour's' march, and saved mysclf a weary tramp of at least eight miles. On the road I met seren native hunters, armed with muzzle-loaders, who told me the Masai had just passed by Lanjora on their way to the coast.

I saw a few mpallah, but they were very wild; and at the end of the day my bag consisted of a ground hornbill, a handsome dark-plumaged bird the size of a large turkey, and a couple of monkcys. Of the latter I shot four, but two stuck in the trees, and of those I brought home one skin was unfortunately ruined, owing to my gun-bearer, Fãas, to whom I entrusted it, getting very drunk and button-holing it all over. I found him regarding the result of his work mournfully, and exclaiming in indignation against the knife he had been using, "I cut it! Me spoilt it! Knife's fault!" Later on in the erening he got still morc drunk, and during a forcible attempt to seize some pombé, the property of a 'Taveta native, reccived a nasty cut over the eye from a 
stick. Immediately he snatched up a knife and rushed to me with the information that "he meant having his assailant's blood ;" whereupon I took possession of the weapon, and made Martin tell him "to shut up." How Martin translated the phrase I do not know, but it had the desired effect; the man appeared to collapse at once, and, consoling himself with a good cry, within an hour or so became once more a comparatively sober and peaceable member of our community, and came humbly to me to have his head plastered up.

I found Jackson still at Tareta, preparing to start for Kahé, and he kindly provided me with a typical hunter's dimner, consisting of soup, fish, uncommonly tough rhino, roast monkey, ibis curry, blanc-mange and honey, native beans, and stewed bananas. Had I not been warned that one course was to be roast monkey, I think I should have considered it good eating, but the foreknowledge doubtless affected an unbiassed judgment, and the dish seemed to smell and taste of the creature's quarters in our well-remembered "'zoo."

The next day the rest of our party arrived from Lanjora, bringing with them a hartebeest, a steinbock, and that excellent prize, a great bustard, shot by $\mathrm{C}$ __ One of $\mathrm{H}$ - $\_$'s men lost no time in getting mad drunk and attempting to shoot a native, so we immediately applied the handcuffs and tied him up to the flagstaff until there was no fear of his hurting himself or anybody else. Drunkenness is the worst trait in the Swaliili character, and apparently the chief object of life directly a village is reached; its complete 
accomplishment converts a comparatively harmless individual into a dangerous and uncontrollable maniac.

As this was $\mathrm{C} \longrightarrow$ _'s birthday, we opened a case of champagne and produced the original Christmas plumpudding, which had been allowed to remain unattacked while we were on the march up-country.

We had arranged to start for Useri the next day, but some liunters ran into Tareta to inform us that the Masai were passing by that way and in large force; so, at Martin's advice, we decided that a day's delay was preferable to the risk of an encounter.

During the night the head of the fine water-buck I lad recently killed was stolen by a hyæna. We were in the habit of cleaning the skulls we wished to keep by leaving them in the river attached to a rope, the other end of which was firmly fixed on the bank, as this method, though slow in its action, is much safer than that of boiling, which is apt to cause fissures in the bones if the water be too hot. It is difficult to conceive how under the circumstances any four-footed beast could have pulled the skull out of the water, so the chances are, my man must have been careless enough to leave it lying on the bank.

On January I gth, starting early from Taveta, we had proceeded about twelve miles north, when we were brought to a sudden halt by the appearance of some thirty natives in the distance. Our men, who, after the late reports, had Masai on the brain rather worse than usual, at once declared we were confronted by a force of these fear-inspiring sarages, and for a moment there 
were signs of general alarm. These cooled down when, on nearer approach, the new arrivals were found to be merely a party of native hunters (Wa-ramba), armed with bows and arrows instead of spears, on their way to Taveta in the hopes of being there able to dispose of the meat they had killed.

Shortly after this C-and I went after a herd of over a hundred buffalo, but they got our wind twice, and though at first they did not go far, the second time they galloped clean out of sight. This was my introduction to the buffalo, and the sight of so fine a herd of these large beasts was very imposing. They were attended by a flock of those birds which bear their name, some hovering over them, while others were busy feeding on their backs. These birds are about the size of turtle-doves, and have a pure white plumage: their principal feeding-grounds are the quarters of the buffalo, just as those of the rhino offer the most attractive maintenance to the rhinoceros-bird. Thus extremes meet, and evidently to the mutual advantage of all concerned. But though the presence of these birds is an undoubted convenience to all parasite-ridden animals, it is also a source of distinct danger, as it is by no means usual for the sportsman to get a first intimation of the position of his quarry by seeing a number of these birds hovering in the air. Before going into camp for the night I was lucky enough to bring down, with a longish shot, a fine water-buck, whose head compensated me for the one of which I had been robbed by the hyæna. 
Our night encampment was situated on the river Lumi, and the spot had been christened by Jackson's men the simba (lion) camp, on account of his having killed this so-called "king of beasts" while staying there some months before. During the afternoon I shot one fine mpallah, but the rest of the party returned with an empty bag, having only sighted distant Granti and ostriches. Overtaken by darkness before I got home, I had some difficulty in finding my way, as, although the country is mainly open plain, the river is fringed by a belt of dense jungle, and its approach made awkward by wart-hog burrows.

It had been previously arranged that, in the event of any of our party being absent at sunset, shots should be fired at half-hour intervals. Three of these signalshots now proved excellent guides, and agreeably upset the programme I had sketched out for the nighta not too pleasant bed in the highest tree I could find. Before entering camp I heard the low growls of lions, proceeding from the bush, which were immediately followed by the unmistakable rustle of moving animals who were a little too near to be pleasant companions in the dark; however, I never heard of any one being seized by them in these parts, the probable reason being that, as antelopes are obtainable in abundance, the lions, though numerous, are not urged by hunger to attack men.

The next morning we separated; $\mathrm{B}-$ and $\mathrm{H}-$ going for one night to a Ziwa, some five or six miles to the south-east of Simba camp, and C__ and I 


\section{PLATE IV.}

No. 1. Granti male (Gazella Granti), shot near Simba Camp; length of horns along the bend 30 inehes, width between the tips 10 inehes.

No, 2. Granti male, shot near Rhombu Camp; length of horns along the bend 27 inches, width between the tips 16 inches.

No. 3. Granti female, shot to the south of Lake Jipé; length of horns 12 inches, width between the tips 5 inches.

No. 4. Granti female, shot to the south of Lake Jipé; length of horns 17 inches, width between the tips 6 inches.

No. 5. Neotragus kirkii male, shot near Mañngu ; length of horns 2 inches.

No.6. Hunteri male (Damalis hunteri), shot on the Tana river; length of horns from base to tip in a straight line 22 inches, width between the tips 16 inehes. 


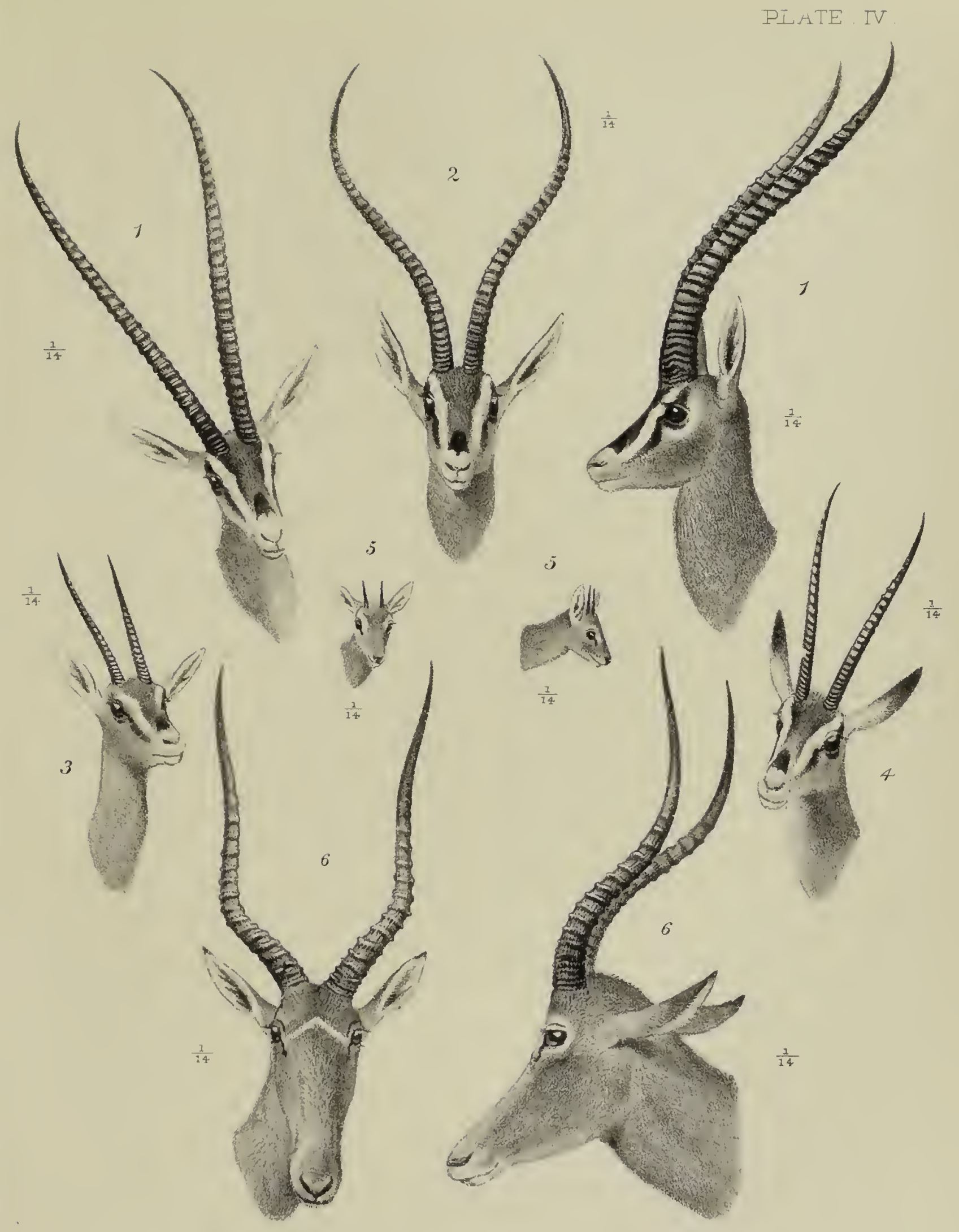



behind the shoulder as he lay broadside. At once jumping up and wheeling round with a snort, he galloped off; and I gave him the other barrel as he passed; but he only ran about two hundred yards, and then stopping short, faced round, and after swaying from side to side for a second, fell dead. He proved to be a grand prize, and was evidently a very old beast, the thick front horn measuring twenty-seven inches in length, and being much more prominently placed on his nose than usual: the back horn also very thick, though it had been curiously worn away on the top and slightly damaged in front. On cutting him up we found two of $\mathrm{B} \longrightarrow$ 's steel-tipped bullets in his neck, one just behind the ear and the other lower down, and it was surprising that neither seemed to have done him any harm. He was clearly the enormous rhino $\mathrm{B}$ - told me he had wounded during his trip with Jackson, and I think he was most unlucky not to have secured him. I have no great faith in the value of steel-tipped bullets, and although I have killed some rhinos with a single shot in the neck, I do not consider it offers anything like the chance of the one behind the shoulder.

After cutting off the head-a very tough and long job-I went after another rhino my men sighted some distance off; but in this case I was less fortunate, as he had lain down in a very bare place, and when I got within a hundred and twenty yards the birds on his back took alarm and disturbed him. Afraid lest he should gallop off at once, I let drive, but with the only 
effect of scnding him clcan out of sight in a remarkably short space of time. I am afraid I could not have made a complete miss, and determined never again to shoot at these animals at such a long range, as I consider it cruelty not to make certain of killing them by getting within at least thirty to forty yards. After this I began my homeward journey, and soon came across a single wildebecst, of which species I had already scen two herds in the distance. My efforts to stalli this creature were much hampered by the hartebcest and zebra, which almost surrounded him, and I had a very long and painful crawl over ground completely strewn with innumerable sharp little stones. It was quite two hours before I got within two hundred yards of my quarry, as I had to stop every few minutes to let some hartebeest or zebra feed out of the way, the wildebeest in the meanwhile always moving slowly on. Having at last got within that distance of him, and not being able to get any nearer, I made a very good shot, hitting exactly where I aimed, behind the car, and he fell in his tracks without a lick. He turned out to be a very good bull; the horms, not unlike those of the buffalo on a small scale except that they do not meet in front, were twenty-scren inches at their widest spread, and sixtcen and a half from tip to tip. He had a thin mane of black hair rumning down his neck and back, and a thick tail tcrminating in a long bunch of coarse black hair; he was about the size of a small English bullock, with a brindled body and duncoloured quarters. These animals are most ungrace- 
ful as they stand, being in the habit of carrying their plain heads rather low, which produces a dejected appearance; but when startled they arch their necks, and moving with great speed and good action become quite graceful. After securing this one I thought I might well be satisfied with my day's work, so returned to camp, after an excellent day's sport, in which I had seen two rhinos, two herds of wildebeest, besides single ones, ostriches, zebra, hartebeest, Granti, steinbock, big bustard, and secretary-birds. I found C— had already returned, having killed a wildebeest nearly as good as mine and a secretarybird. The latter, about the size of a crane, is grey in colour, rather long in the leg, with a small crest of dark plumes, and is a valuable destroyer of snakes.

In the evening $\mathrm{B}-$ and $\mathrm{H} \longrightarrow$ came in from the Ziwa, as we had intended moring at once to Useri, but after secing the good horns I had brought back they kindly consented to stop and shoot here another day, to give me time to get through my skinning. 'They had at the Ziwa killed three moderate rhinos, besides hartebeest and a silver-backed jackal, and seen a herd of buffalo, which had eluded pursuit by at once taking refuge in a swamp covered with tall thick reeds. I am glad to say they did not lose anything by the delay, as the following day's shoot resulted in three Granti and a very good rhino killed by $\mathrm{C}-$ the froutal horn measuring twenty-cight inches in length. 
While I remained in camp some of the Wa-rhombu paid a risit to barter bananas for meat. They are quite the lowest type of all the natives inhabiting the Caga districts of Kilima-njaro, wild in appearance, and quite naked, with the exception of a thin skin belt, through which are thrust their short swords, knires, and knob-kerries, and all carried oval slin shields and spears of inferior workmanship. They were quiet and inoffensive emough, and seemed to be rather afraid of us; but Martin said if they caught one of us alone they would probably try and rush us with the riew to securing our weapous.

I bagged a spotted hyæna this morning in one of the lion-traps I had set the previous evening; I felt certain something was caught, as I was awakened in the middle of the night by a tremendous yelping. These brutes, of which there are a great quantity everywhere in this country, are about twice as big as a large retricver, of a dirty brownish-grey colour with black spots, and have most formidable jars. 'Their' skins are worthless, being always mangy ; but as hyænas are held in dread by the natives on account of their depredations upon the cattle, we felt no compunction about their slaughter.

I had a great job with the rhino head, as I tried to keep the back horn on the skin, and so had to hack and chop away at the front horn rery gingerly. I afterwards found it was a mistake to attempt this operation, as the skin only rotted away during the 
process of drying; whereas it is perfectly easy to remove the back horn by dissecting away the soft tissues, and then, when the whole skin is removed from the skull, to chop the front horn from the bone in which it is firmly fixed. 


\section{CHAP'TER XIII.}

Game abundant and various-The Useri and their chief-Shameful treachery of a slave-trader-A tough rhino-A capital morning's sport-Phinoceros tricornis-A native scrimmage and feast-danceEffective charge of a rhino calf.

WE made an early start next morning, and marched about fifteen miles north-east to within a short day's journey of Kimengelia, on the frontier of the Masai country, where we were warned to be careful not to go far from camp without an escort of at least twenty-five men. On this march $\mathrm{C}$ — shot, brought down a fair Granti, and we came across two rhinos. Having won the toss for the stalk, I had crawled up to within thirty yards, when the larger one, disturbed by the birds leaving his back and flying around his head, got up and looked about suspiciously. Fearing he would make off, and being unable to get a clear shot behind the shoulder from the position in which he was standing, I aimed just below his ear, and he fell over most ungracefully, while his companion bolted. I then cautiously approached; but on getting close, as the beast showed signs of returning life, I retired to the shelter of a bush about ten yards off and awaited results. After beating the ground with his great head and wriggling his body after the fashion of 
a rabbit shot through the brain, he jumped up and made a furious attack on the bush under which he had been lying, but a second shot from my $577^{\circ}$ rifle soon put him to rest for ever. Meanwhile the other rhino, unperceived by me, had trotted back to within eighty yards. $\mathrm{C}$ - went after him, but began shooting at too long a range, as after each shot the beast, instead of running away, made a series of short forward dashes, shaking his head defiantly, as if he meant to charge something, but could not quite make up his mind what to go for. After the fifth shot he moved off slowly, crossing within a hundred and fifty yards off $\mathrm{C}-$ and $\mathrm{H}-$, who bombarded him with five more shots, none of which seemed to have any appreciable effect. The caravan then moved on, while I remained behind to take off the horns of my rhino, which, though thick, were not very long. During the operation a steinbock came feeding within three hundred yards of me, and allowed me to walk quietly up and obtain an excellent shot at a hundred yards.

The grassy plain through which we marched was simply crawling with hundreds of Granti, wildebeest, hartebeest, and zebra, the two last being singularly tame, watching us with idle curiosity, and never attempting to move before we got within fifty yards of them; then with a buck and a bound they started off, stopping every forty or fifty yards to turn and take another good look at us. Having sufficient meat, we did not attempt to molest any of these creatures.

Our new camp was picturesquely situated among 
high trees on the extreme north-east point of the Kilima-njaro slope. Close by are the sources of the Ksavo or Useri river, which flows in a soutl-east direction as a tributary of the Sabaki river. 'These sources, of which as far as I could make out there are two, rise direct from underground springs, though in connection with them a dry nullah extended in a northwest direction, which was evidently flooded in the rainy season, as its banks were bordered by magnificent green trees. 'This was the most northern point reached during our wanderings, and here we obtained the first fair view of the snowy top of Kibo, peeping out to the north of Kimawenzi. I regret we did not continue in this direction at least as far as Kimengelia, for in that district $\mathrm{B}$ - had most excellent sport during an expedition he undertook a year later; but we were desirous to return shortly to Taveta and arrange a trip to Mount Meru, in addition to which the Masai were reported to be in great force, and in our direct line had we proceeded farther north.

About three hours' march up the mountain lives the somewhat powerful chief of the Useri people, who has at least two thousand warriors under his command. When Martin was with General Mathews he paid him a risit to induce him to fly the Sultan's flag, and had rather a rough time of it, as the Swahili traders in irory and slaves, through jealousy and fearing he had come to buy ivory, persuaded the chief that the object of his visit was to practise magic. Upon this representation he was kept a close prisoner for a fortnight, 
during which time he got nothing to drink but banana water, obtained from the stems of that plant. After becoming a blood-brother of the chief, Martin managed to escape by a ruse. Producing a musical-box, he presented it to the chief, and after winding it up slipped quietly down the hill while the people were engrossed in watching the working of the wonderful toy.

On arrival here we were surprised at the coolness of our reception by the natives. But for the visits of one or two Useri warriors, we were comparatively boycotted at first; but after a day or two women and children appeared in great numbers laden with bananas and grain, which they were willing to exchange for meat. We found out the reason of a general visit being delayed was due to the fact that some time before, Jumba Kimameta, an Arab ivory and slave trader, the same whom Count Teleki had engaged to organise his caravan, had passed by on his way to the coast with a cararan of a thousand men, and after inviting the natives to bring down food for sale, had most treacherously killed all the men and carried off the women and children as slaves. The chief, therefore, on our arrival, permitted his warriors to interview us should they so feel inclined, declaring that they ought to be able to take care of themselves, but declined to allow any of the women or children to accompany them until he was fully satisfied as to our intentions. No wonder the poor creatures regarded us with suspicion after a shameful treachery had been 
recently practised upon them which called loudly for vengeance; but we were glad to find, after a few days, they quite got over any sensation of distrust and became most friendly, and on realising that sport was the object of our presence, gladly volunteered assistance, and were soon scouring the plain in every direction to mark down rhino and other big game.

The entire district was undulating and studded at intervals with tall trees, wide enough apart to admit of animals being easily spied, while here and there patches of thick bush completed the perfection of a game-country as far as physical features were concerned. I saw nothing for some time during the first day except hartebeest, moderate Granti, and a few wart-hog scampering away with tails crect without giving me a chance; but later on I caught sight of a rhino, which had evidently got our wind from the rate at which he was moving. Before he was well out of sight I came upon two others, which gave me an example of the amount of lead a rhino, hit in the wrong place, can carry. Having singled out the best of the two, and not being able to get a fair shot on account of the bushes, I hit him too far back, with the effect of knocking him over for the moment. As he rose I gave him my second barrel in the quarters, which made him face about and give me time to reload. An unfortunate incident occurred when I pulled the trigger for the third time, as both barrels went off simultancously, with the only result of nearly paralysing my shoulder. Meanwhile the unwounded 


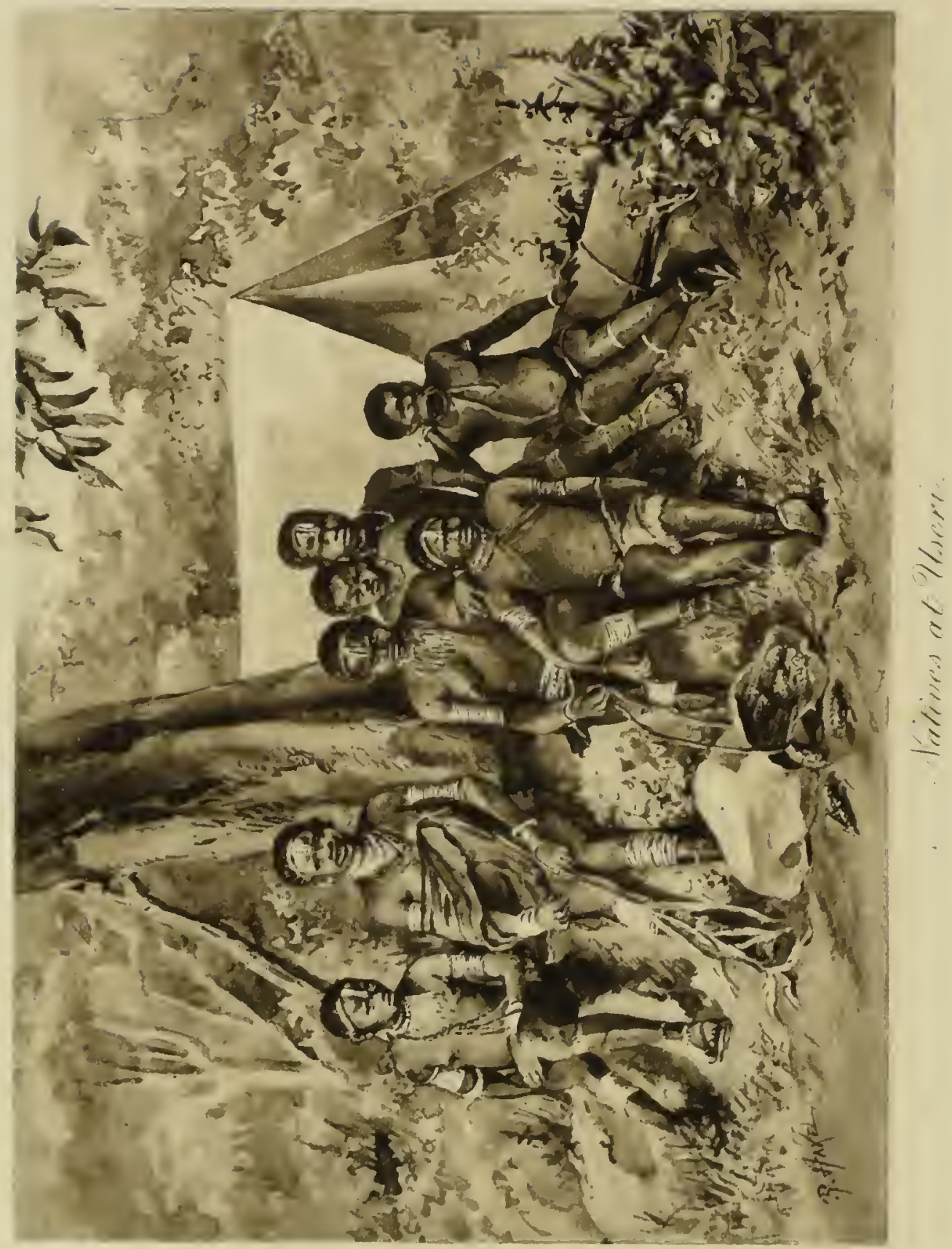


rhino, who had been running in a circle, was closing in upon me; so, as I thought he looked dangerous, I gave him a shot from one barrel of my eight-bore, which sent him clean away, and with the other barrel fired again at the wounded one. The effect of this shot was that he moved slowly into the open plain, where he continued to wheel round and face me whenerer I tried to approach him. At last I got within forty yards by dint of short rushes whenerer his head was turned arvay, and finally dropped him with a shot in a vital place. On examination I found the first bullet had struck about one foot too far back, the second had smashed his hip, the third had broken his shoulder, and the fourth penetrated the lungs.

While cutting up the meat a few Useri natives arrived, and one made me a long harangue, condensed by the interpreter into, "Why white man come here if he meant no harm, without going to see chief?" I replied we might pay the risit later on, but in the meantime he should tell his people to come and see us at our camp, and bring honey and bananas. During my return I met two more of these strange natives, one of whom fired off a gur, and the other, brandishing his spear, treated me to an impromptu war-dance; then both rushed up, and shaking me warmly by the hand, led the way to our new camp.

Here a most animated scene presented itself. Natives loaded with yams, bananas, grain, and other produce, which they were anxious to barter for cloth though not for meat, were especially conspicuous by their almost 
entire absence of clothing, the complete costume of the men being a liberal coating of clay and grease, and a scanty belt of untamned leather which held the inevitable knob-kerry and linife. They were mostly of medium size, active, and armed with small-headed spears of inferior workmanship, oblong hide shields, and short swords. Among the ladies I noticed a few who would have been well shaped, had they not ruined the contour of their arms by heavy coils of iron wire wound tightly round their flesh during childhood. A tiny petticoat, a few beads, with anklets and bracelets of wire, completed their visiting dress, and most were accompanied by some of the plumpest children we had hitherto had the pleasure of meeting. All appeared thoroughly bent on businesss and comparatively free from curiosity - a rather remarkable fact, as, up to our arrival, their part of the country had only been visited by three other white men.

The whole of the eastern slopes, which extend for some forty miles, are, like the southern or Caga slopes, inhabited to about five thousand feet above the sea-level, and present similar banana plantations and shambas: but beyond this point all is dense bush and forest. Before night the chief of Useri sent down a present of one goat and ten loads of bananas, and in return we promised to send up a load of fancy-coloured cloth and our compliments. We decided not to pay him a visit, as Martin assured us we should be unable to get away if we did before some ten loads of cloth had been handed over, and Martin was by no means a bad judge. Ile 
also told us a personal visit would entail delay, an additional reason for dispensing with the formality, as we were even more anxious to economise our time than our cloth.

During this day, which resulted in a bag of five rhino and one Granti, a curious sight was witnessed by $\mathrm{B}$ - - He had come upon two rhino and wounded one sererely, whereupon the companion attacked it with great fury and finally knocked it over. The poor creature remained where it fell, with all four legs fighting the air, and $\mathrm{B}$ - thought the coup de grace had been given in a way for which he was not responsible; but after a number of violent struggles it regained its feet, the simulated death-throes resulting from its having been cast and wedged between two small trees.

During the next day's sport the game had all the best of it. We started out in pairs, as the Masai were reported to be on their way to demand hongo (blackmail), and in strong force at Kimengelia, some four hour's' march north of our camp. I only obtained one Granti, shot from the left shoulder, as my right was too bruised and painful from the effects of the double discharge of the previous day. B- secured a rhimo, but neither of us got within fair range of the game, as the ground was much disturbed by parties of natives visiting the numerous game-pits and cutting grass for their cattle. We saw zebra, hartebeest, wart-hog, giraffe, and some moderate rhinos, but all were more or less on the more.

During the night I had a rather sharp attack of 
ferer, which I combated by copious draughts of hot tea and an early turn in to a bed piled with innumerable blankets. Not unnaturally, I felt "cheap" and feeble the next morning, so remained in camp amusing myself by watching the numerous natives, while the others went off in search of game. Martin, with a happy readiness of thought, told some of the natives they might have the meat off a rhino skull $\mathrm{B}$ - w was anxious to lieep; whereupon a dozen of them set to work with a will, and in about ten minutes had picked the bones perfectly clean-a performance which would have occupied our own men for at least two hours.

At about Io A.M. some natives reported "two big rhinos quite close;" so after them I started in all haste, lightly equipped in a suit of pyjamas. But, as usual, "quite close" meant a long four miles, and my annoyance at having allowed myself to be hoaxed into believing anything ever could be "quite close" was deciding me to abandon the hunt, when I sighted them standing under a solitary tree in the open plain, attended by a half-grown offspring about the size of a big bullock. They were awkwardly placed, and after getting to within a hundred yards I had to wait some time, as the two big ones were actively engaged in carrying on an animated flirtation. At length they lay down, thus enabling me to crawl within thirty yards, at which distance all three rose suddenly and faced me -an anxious moment, during which I fcared a charge or a bolt before I could get in a shot. For about one 


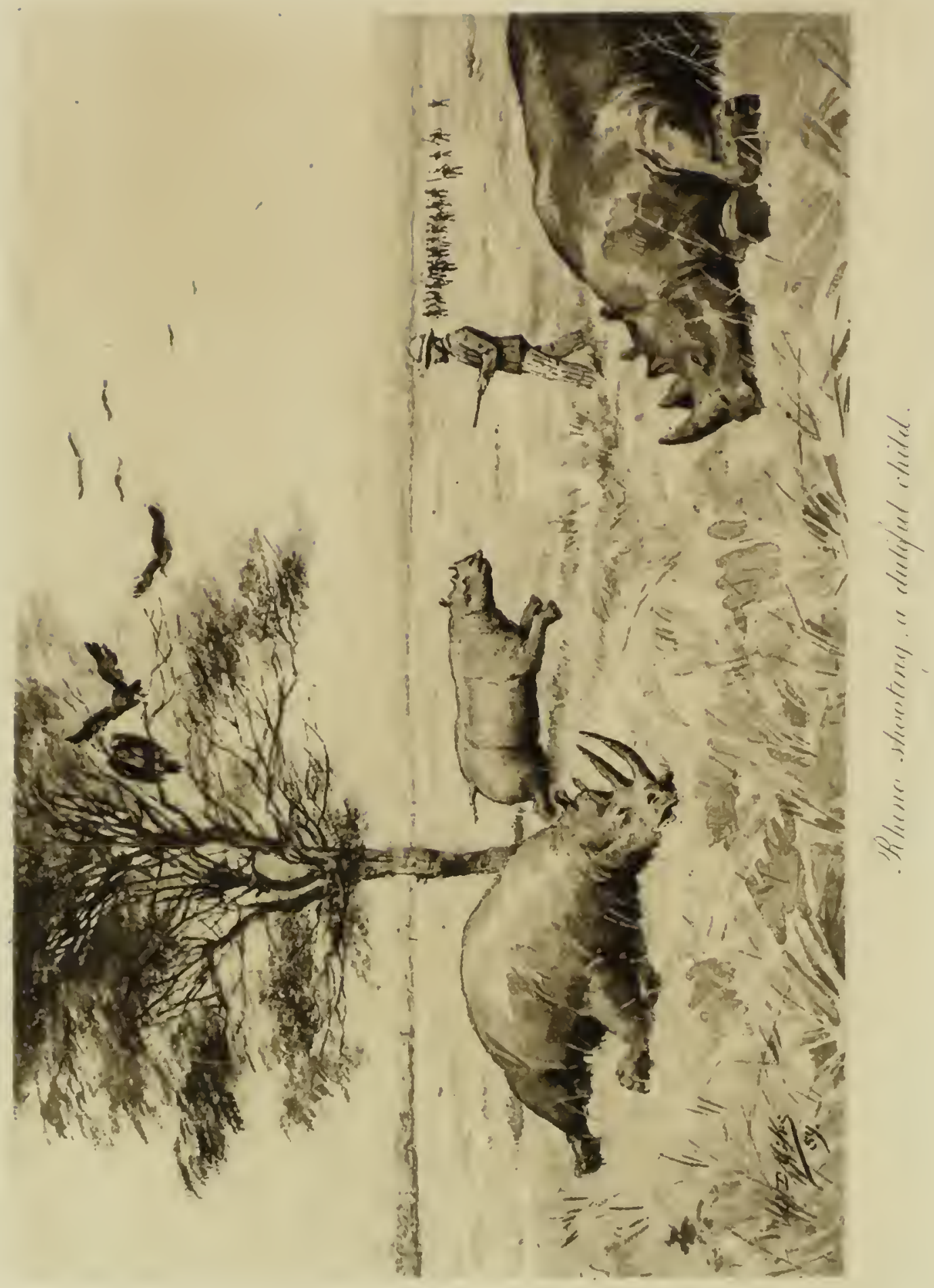


minute, which seemed to me many, they were motionless, and then turned inquiringly towards each other. Seizing the first opportunity of a broadside shot, I bowled the cow over with a bullet behind her ear. The bull ran some twenty yards and then stood, until a shot from my second barrel took effect in his neck, and brought him also to the ground. Wishing to spare the half-grown one, I tried to drive him off; but at twenty yards he came for me, so I had to stop him with a bullet in the chest. 'Thinking he was done for, I reloaded and approached him, upon which he rose and again charged with a vengeance. I fired my first barrel without effect, but knocked him over with the second when he was within five yards of me. It was, perhaps, fortunate this shot dropped him, as, although I jumped aside after firing, I think it very doubtful whether my activity would have proved equal to his.

I now proceeded to examine my prizes. The cow proved a splendid beast with symmetrical horns measuring twenty-two and twenty-three inches. The bull was also a fine specimen, as well as an anatomical curiosity, for in addition to short anterior and posterior horns, he had developed a third horny excrescence far back, sufficiently distinct to entitle him to be considered as a unique example of the Rhinoceros tricornis.

The natives, who had led me to the rhinos, got up a row with some fresh arrivals attracted by the shots and the prospects of obtaining fresh meat. Loud yells, drawn knives, and brandished spears threatened an immediate scrimmage, which I was only just in time to prevent 
by dashing into the midst of the fray and settling the question by telling the natives who had shown me the rhinos to turn their knives and spears in the direction of the young rhino. This satisfied them at once, and they were soon actively engaged in covering themselves with its blood, dancing and screaming with delight as they secured the most coreted pieces, as all well-bred sarages should.

On returning to camp I found that $\mathrm{C}$ - had killed two rhinos and a calf, but $\mathrm{H}-$ and $\mathrm{B}-$ had come in with an empty bag. We decided to delay our departure for another day, to give me time to skin the cow's head, which I had removed whole, and to photograph the three horns I had chopped away from the dead bull.

While engaged on this work the next morning, the cry of "Two more rhinos quite close" reminded me of yesterday's four-mile tramp, but this time I went off prepared for a liberal interpretation of the phrase. For nearly an hour I followed my guides, attended by a howling mob of four hundred natives, and then came in sight of a rlino which had evidently winded us, as he was moving rapidly forward. We followed him for about two miles, when he halted under a bush; but after stalking up to within thirty yards of him, I found I could get nothing but a front shot. As an experiment I fired, aiming just above the eye, and he fell stumned, but quickly regaining his feet, made off' with astonishing rapidity. We then went in search of his companion, reported to have taken refuge in a patch of thick bush 
no great distance off. Here I tried to organise a drive, into the spirit of which the natives entercd to the extent of climbing the outlying belt of trees and yelling bravely. This mancurre resulted in my first getting a glimpse of a pair of horns, then hearing the beast crashing through the bush with a succession of loud snorts, and finally seeing him plunging rapidly across a small open space; here I got in two snap-shots that had the effect of maling him leave the covert and seek the open plain. In spite of my entreaties, the attendant natives went howling after him, until, brought to bay, he charged one of the boldest, and, though severely crippled, pursued him for about one hundred yards until he nearly caught him. Then he stood puffing and snorting; apparently too exhausted to continue the chase, and enabled me to put him out of any further misery. The accomplishment of this feat was followed by the efforts of four hundred natives to shake me by the hand, in which they were partially, and as far as I was concerned, more than sufficiently successful. To this succeeded a sort of war-dance round the carcass of the rhino, during which the performers caught each other tremendous smacks with their knob-kerries, every give and take being received with the utmost goodhumour and apparent enjoymcnt.

I made my cscape towards the camp directly I had obtained their promise to bring on the mcat, detailing the only two men I had brought out with me to see that promise fulfilled; but my back was scarcely turned when they stripped the carcass to the bone, leaving 
my watchers nothing but a pair of horns and one foot as evidence of the morning's sport.

To-day C_, after a long hunt, killed four rhinos, one of which took nineteen shots, while B- and $\mathrm{H}$ - had no luck at all. I believe the best thing to do in a country full of these creatures is to sit still in camp and wait until natives come in and report a beast "marked down;" especially if, as in our case, you find the greater part of the male population only too anxious to lieep a sharp look-out, in the hope of being rewarded by a feast.

Notwithstanding our heary slaughter of rhinos, not a particle of meat was ever wasted, for we made it a standard rule that no animal life should be sacrificed for mere love of sport.

The men we had sent back to Taveta to fetch the present of cloth for the chief of Useri returned during the afternoon, having been slightly delayed by the charge of a rhino cow and calf. 'The head-man having killed the cow with a shot from his Martini-rifle, was charged and nearly trampled to death by the calf, before the rest of the party by wild firing managed to drive it away, apparently uninjured. While in this camp I succeeded in photographing some of the women and children, but the men with one voice declined to risk being operated upon. 


\section{CHAPTER XIV.}

A river encampment--A good day's sport, and a narrow shave $-A$ donkey in trouble-Return to Simba camp-Lake C'ala-Characteristics of the rhinoceros.

We struck our camp on January 28th, moving some eight miles down the river. On the way we might have shot numerous zebra and hartebeest, as the natives on either side drove everything they saw in our direction, hoping we would provide a farewell feast. After realising their object, we shot one hartebeest, leaving them to deal with its remains on the national principle of first come first served.

We selected a very favourable spot for a camp near a bend of the river, where tall shady trees protected us from a heavy downpour of rain, lasting nearly two hours, which probably accounted for my being laid up with a relapse of fever. During the evening Cačeche, the head-man, came in, having duly delivered our present to the chief of Useri, who expressed himself much pleased, and only regretted we could not prolong our trip and hunt the Kimengelia district, where, he declared, buffaloes and rhinos were killing his men every day. The chief sent us a return present in the form of a bullock, which arrived in detachments, as the poor beast was too fat to walk any distance, 
and had to be killed and cut up half-way from our camp.

All these mountain tribes keep their cattle in huts from the day of their birth, and never allow them to graze for fear of the raiding Masai-a fact which accounted for our meeting such large parties of grasscutters descending to the plain. No sooner lad we left our last camp than its thorn-hedge was fired, lest a Masai occupation should represent a lair from which they could pounce upon any small detachments sent down in search of forage.

The men caught quantities of fish here, of fair size and excellent flavour. 'The surrounding country was picturesque and well suited to a variety of game; low undulating hills, with here and there belts of wellgrown mimosa, resembling from a distant view stunted cedars, and tracts of fresh green grass, the result of recent rains.

I was awakened in the middle of the night by $\mathrm{C}_{-}$, who heard strange sounds in the bath-room attached to our tent, where, after lighting a match and seizing a stick, I discovered a rifle, pouch, belt, mat, and a few dirty clothes. I was just going to pounce on these, when an arm suddenly appeared under the side of the tent, and as suddenly disappeared with the rifle. I rushed outside, but the owner of the arm had vanished in the darkness; so I returned and handed over the rest of his belongings to Martin, who with their aid easily discovered the culprit. We had no objection to any of the men taking shelter in our tents during rain, pro- 
vided they obtained leave to do so; but to force any entry without permission was an offence, and they were aware of that fact. On further exploration of the bath-room, I was led, by my nose, to a suspended bunch of almost putrid meat, which I felt sure belonged to my gluttonous friend Anole; this I hurled into the bush-a sufficient punishment and the only one practicable, as Anole was far and away too splendid a liar to ever admit any wrongdoing.

My fever left me before morning, and the day resulted in my obtaining capital sport, though at one moment I was the mark rather than the marksman. I had killed one fair rhino, and seen many zebra and hartebeest, when, by ascending a small hill, I overlooked an arid extent of plain, enlivened by two herds of Granti and four rhinos. I went for the Granti first, and after some little trouble killed a good buck with horns twenty-three and a half inches in length; I then turned my attention to a big rhino cow and calf, the central features of a wide flat area clothed with young grass interrupted by a single ant-hill of no great size. The stalk was very difficult and wearisome, but I succeeded in crawling to within one hundred yards of the mark, my favourite gun-bearer, Fāas, following with my eight-bore. Suddenly I was deafened by an explosion, and distinctly felt the wind of a large bullet as it whizzed past my ear. For a moment I was too dazed to exactly realise what had happened, but, on recovering my wits, recognised how narrow my escape had been, as nine times out of ten the rifle, carried by a 
native gun-bearer, is pointed straight for the middle of your spine when you are crawling into game. I would advise all sportsmen to insist, as I did after this episode, upon all their gun-bearers following with the butt of the rifle advanced. On turning round, I found my boy Fàas dancing about and tearing his hair under the impression I was dead; so I caught hold of his leg aud pulled him down, for by this time the rhinos, startled by the report, were, strangely enough, advancing slowly upon us, instead of rumning off in the opposite direction. 'They came on so straight that I began to think they would walk right over us, without giving me a chance to shoot, but the big one turned and gave me a slanting shot within twenty yards, and with the second barrel of my $577^{\circ}$ rifle I finished her before she had gone any distance. I regret to add that the half-grown calf would not be driven off, and, mindful of my last experience, I declined to risk a charge. In firing at it I must have cocked both barrels, a thing I had been careful not to do since the last time they went off together; anyhow, the same accident occurred, but luckily without knocking my shoulder about very severely, as it was now protected by a sponge placed inside the coat. This was, of course, regarded by the natives as some mysterious magic (mchowi), introduced with the idea of enabling. me to shoot straight and to liit hard.

The adventures of the day were not yet over, for as I was riding home, on the donkey I had brought in case I felt weal after my recent bout of ferer, I came 
across a long line of native game-pits near the river. Feeling too lazy to gire these traps a wide berth, or to even dismount and lead the donkey, I tried to guide my animal between two of them; but a wilful donkey is no easy ship to steer, and when exactly between two pits he suddenly swerved towards the seemingly nice smooth path orerlying one of their mouths. I jumped off just in time to pull his head round, but not quickly enough to prevent his hind-legs dropping through the trap; then I hung like "grim death" on to the rein and one stirrup-leather, and managed to keep him up till my gun-bearers arrived. We then hauled him out by the fore-legs after hitching the reins under his tail-a fortunate result of the accident, for had he gone to the bottom we should have been obliged to dig him out, as these game-pits were from eight to ten feet deep and scarcely three feet wide at the mouth.

I found, on returning to camp, that $\mathrm{C}$ —_ had killed two Granti with fair horns, B- two rhinos, $\mathrm{H}-$ three rhinos including a calf, and the first oryx-beisa. This is a beautiful antelope somewhat bigger than a red-deer, of a reddish-brown colour, with legs and head most prettily marked in black and white, a long tail bushy at the end, and straight slender horns, with a backward slant, annulated two-thirds from the base upwards. It was not a very good bull, as the horns were only twenty-two and twenty-four inches long respectively, and we afterwards got some with horns over thirty inches in length. Those of the cow are similar in form, but more slender, and it is a peculiarity with 
the whole gemsbok species that one horn is generally longer than the other. Altogether, eight rhinos, three Granti, and one oryx represented no bad day's sport, and after cutting up the meat and despatching it to Taveta, we sat down to some of the best beef we had ever tasted. I do not think there would be the grumbling so often heard, in some of the best clubs in London, if the members could ahways get an entre côte equal to that provided by the Useri bullock, notwithstanding the fact of our healthy appetites having something to do with our most particular approval.

We had another day's shooting here before returning to Taveta, and our bag consisted of one rhino, one Granti, and one hartebeest, shot by $\mathrm{B}-$, one striped hyæna and one mpallah, shot by $\mathrm{C}-$, who also saw eland, one wart-hog and one Granti shot by $\mathrm{H}$ _

We left next day for our old Simba camp, each taking a separate track, but arriving nearly at the same time, after traversing a monotonous line of country divided between barren rock and dense grass jungle. We all reached our destination empty-handed, though I passed two rhinos within easy distance; but we were not in want of meat, and I had no desire to destroy any more of these beasts, unless I conld do so for some useful purpose.

C - lost a good chance of getting a buffalo bull, as the bearer of his cight-bore was lagging behind, at the particular moment his immediate presence, to the fore, was required. We all, in turn, came upon a long 
string of some four hundred natives, when we were within a few miles of the Simba camp, and curiously enough each one of us decided to display our valour, to its best advantage, by discreetly squatting in the long grass and allowing them to pass without exhibiting the slightest sign of interest. Had we indulged in a native curiosity, at the expense of a national proverbial philosophy, I think we should have merely exchanged greetings with a party of Wa-rhombu returning from cutting grass, for they were in the habit of renturing out in large parties, lest they should encounter some of the Useri people, with whom they were on hostile terms.

After resting for one night, at Simba camp, we started again for 'Taveta, C__ and I making a slight detour, by climbing the lower slopes of Kilima-njaro, which enabled us to visit the curious subterranean Lake Cala. No sooner had we ascended the low hills encircling its eastern shore than we were rewarded by a glorious view. At least a thousand feet below us nestled the lovely little lake, somewhat triangular in shape and from one and a half to two miles in its widest diameter, completely embedded among hills and cliffs - a basin in which the great Masai mountain god could always wash his liands. From our position its slores appeared inaccessible, but the natives declared a descent was practicable in one or two places. Below the rocky cliffs, beautifully wooded slopes, of raried lunes, appear to rise abruptly from the deep blue of the lake, whose surface is unruffled by a single ripple. Fish were said to be abundant, and Jackson told me lie 
had once caught sight of an alligator, but how it came there, seeing there is no apparent outlet, he could not explain. We walked round to the south side, and I took several photographs of the lake from different points; but, to my great regret, most of them have turned out badly, especially one, in which I included old Kibo with his white head poling out above a mass of clouds.

After leaving Lake Cala we had a hot march, of about four miles, before reaching the welcome outskirts of 'laveta forest. Here we halted under a grand tree some two hundred feet in height, and measuring thirty-two feet in circumference, and, after a short rest, slowly wended our way through the forest until we reached our headquarters.

On the whole, I think we had every reason to be satisfied with the result of our fortnight's shootingtrip. Forty-threé rhinos, besides wildebeest, hartebeest, Granti, mpallah, steinbock, oryx, striped and spotted hyæena, wart-hog, and silver-backed fox-a total of seventy-five head.

All the rhino we killed were of the black species with prehensile lips (Rhinoceros bicornis). They are in the habit of feeding in the bush during the night, and at about IO A.M. seek the open plains, selecting a spot, generally a clay puddle shaded by a solitary bush, where they lie down to sleep during the heat of the day. At about 5 P.M. they wake up and move slowly to the bush; therefore the easiest times to spy them are between 9.30 and II A.M., and from 4 to 6 P.Mr.; at these hours they may be found standing still and 
staring stupidly about them, or walking leisurely across the plain. I found them the dullest of all the wild beasts I encountered, free from natural vice, and by no means dangerous to any hunter who can keep his head cool. Their charge is easily aroided, even at close quarters, as, though they may come for you at a great pace, they are unable to turn quickly. I believe most of the stories of vicious charges through caravans are greatly exaggerated by the natives and porters, who are, according to my experience, terrified by the smallest rhino; and the majority of those graphically described vicious charges are, I feel convinced, due to the stupidity, and not to the viciousness, of the beast. Caravans a mile long, making, as they all do, a great din by singing and shouting, often pass close to a sleeping rhino. The beast, suddenly awakened by the uproar and having very indifferent visual powers, starts into an aimless headlong gallop; this probably carries him through the line of porters whom he scatters in different directions; but, having accomplished this feat, he shows no disposition to return to the attack unless molested. More than once I have passed a rhino and seen him come charging up-wind after me, out of mere curiosity, routing the gun-bearers right and left, and then, on getting close, sheering off and galloping out of sight as hard as he could go-a clear proof to me of the absence of any vicious intent. On the other hand, I have conversed with several men of considerable experience in rhino-shooting, who assure me they have seen the same species of rhino charge most viciously, 
and also return to the charge. One friend instanced a personal uncomfortable adventure in which he was chevied by a rhino for nearly half-an-hour, and only just managed to escape. The conclusion I therefore arrive at is, that at certain seasons, like many other wild animals, including our Scotch red-decr, they are in that condition of "must" which renders them, for the time, vicious and vindictive, their normal condition being the exact opposite.

Most of the men got royally drunk on our return to 'Taveta, and made night hideous by howling to the strum of their tomtoms; but this, we knew, was an invariable rule whenever they came into headquarters, and a licence with which any interference, on our part, would have been unwise. 


\section{CHAPTER XV.}

Taveta-Attack on a Swahili cararan-The loss of a wife-Arrival of the Bishop of Mombasa-Domestic troubles-The start for Monnt Meru -Abundance of large game-B__'s narrow escape-Kahé forestThe Wa-kahé-Mutinous porters-Short rations-The Mount Meru trip abandoned on account of the Miasai-A luclicrous Masai scareThe Sogonoi mountains.

WheN we paraded our men, the morning after returning to Taveta, to take their rifles into store, half of them asked to be allowed to return to the coast as they declared the work was too hard. They had certainly had a rough time of it, as, nearly every day, we each requisitioned a following fifteen men, in order to get home the meat we shot.

The Swahili porter is an excellent hard-working fellow on a march, and will carry his load day after day for any distance without grumbling; but when once a journey is orer and you are settled in a camp, no matter for how long, he expects to have nothing to do beyond making a boma, and, if the weather is wet, building his own grass hut: this accomplished, he is only prepared to idle about as a gentleman at large, and to eat, sleep, dance, and sing. Such a programme being quite unsuited to our requirements (for we did not want to travel any very long distances), we explained to them that they must work for us in camp, 
but, as a compromise, agreed that, whenever we happened to be at our 'Taveta headquarters, they should leave off for the day at noon, an arrangement which would enable us to get a good six hours' work out of them when necessary. This agreement-the Sundays thrown in as whole-holidays - was fair enough, and they were satisfied.

We found that we should have to stop a week at 'Tareta before starting in the direction of Mount Meru, as more supplies had to be collected and our trade beads made up in strings. Food, for some reason or other, scemed to have become a very scarce commodity, or else the Wa-tareta were attempting an extortion, as they now asked double prices for loads of grain and bananas. We rather upset their market by sending off fifty men to Ughono to buy food there, and, after a three days' absence, they came back with thirtythree loads, to the discomfiture of the Wa-taveta who at once came down to their old prices. Our men also brought back two hens-a great luxury and rarity in these parts. They reported that a Swahili caravan, forty strong, had been attacked near Lake Jipé by Masai, who had killed several and stolen all their goods. 'The surprised Swahili of course took to their heels and fled to the Ughono people for refuge, but it was the idea of Martin and Caěeche that the original attack was made by some of the Wa-ughono, disguised as Masai, for Caěeche had noticed a great deal of new cloth amongst them, and when he suggested bringing the refugees back with him to 'Tareta, he was told 
to mind his own business. This made him think they were being kept, more or less, as prisoners, and Martin said that such was most probably the case, as some little time ago a great many Ughono women and children had been kidnapped by a large Swahili cararan and carried off for slaves, and some form of retaliation was naturally to be expected.

It rained frequently during our stay at Taveta, and cur bright little River Lumi became quite a dirty red colour, while all sorts of filth swept past our encampment, including the decomposed body of a native. Two of our porters were at this time attacked with smallpox, and of course had to be isolated. One of them eventually died, but the other recovered. I regretted to find on our return that poor Belail, who was so seriously and mysteriously ill on our first arrival, and whom I had tried to doctor, had succumbed during our absence.

We caught several hyænas and a civet or two near our hut and in some of the shambas of the natives. A Wa-tareta man one morning came in, and without the least evidence of distress, said his wife had been carried off during the night by a hyæna, and requested the loan of one of our traps. It is extraordinary how little ralue these people seem to set eren on the lives of near relations, but perhaps in this instance the loss was a happy release for the husband. I do not think any hyæna would have been bold enough to carry off a native, and the robber was most probably a leopard, as there were some of these bold marauders about. Later on we caught one in a trap, a singularly daring and 
troublesome beast, who was in the nightly habit of jumping into the drying-yard, and had carried off one of our goats and sereral fowls.

The Bishop of Mombasa came to 'Taveta and spent a day with us on his way to visit Mandara. He had made the joumey in eleven days, including a halt of two days at Ndara. 'This was uncommonly good going, but the loads told off to his porters were curiously light, two men carrying his bedding on a pole, when the whole load represented a weight less than one good porter is prepared to carry. Of course, the Bishop, coming from India, knew nothing about these matters, and the mission men no doubt imposed upon him; but it was, I fancy, originally the fault of other missionaries, who, as I have already shown, would not allow their adherents to carry a weight exceeding fifty pounds. I suppose it makes a difference when you are spending charitable old ladies' money instead of your own. The Bishop was full of schemes, and proposed to make a proper road from Rabai to Ndara and establish a camel dauk; this would greatly improve the facilities for trade, as the road might be made at least thirty miles shorter.

The others went out shooting most days while we were at 'Tareta, but I took things easy and looked after my heads and skins, of which I was beginning to get a pretty good show. 'Their bag included a lesser kudu, a rhino, an mpallah, a bush-buck, and a new antelope, the name of which none of us knew; it was rather bigger and stouter made than a steinbock, 
of a reddish-brown colour, and with short annulated horns about five inches long.*

A shooting-trip in the wilds of East Africa is capable of relieving a man from perhaps all domestic troubles save one-the personal attendant. Be that attendant a "he or a she," a "black or a white," the very name is synonymous with trouble. My man Anole I found quite incapable of packing up my things in time, so I had to engage an additional help named Preston. Anole was excitable in disposition, and consequently active at times. Preston was meek and mild, and consequently slow always. I thought they would act as a foil to each other, and that out of two bad servants I might get the effect of a single good one, but I was grierously disappointed. At Taveta, Preston got idiotically drunk, and quarrelled with all the cookboys; while Anole (who, I suppose, wanted to join in) had a row with our head Indian servant, John, because he would not let him sleep in the cook-house, and implored my permission "to pull his beard and to give him a good licking."

Though our native bearers never treated us with disrespect or familiarity, they always referred to us in a distinctly personal manner. $\mathrm{B}$ - was the big master (mbwana liubwa), C__ the little master (mbwana kidogo), $\mathrm{H}$ —— the fat one (nene), and I, for some reason best known to themselves, the "masher" (mulladadi), which, being literally interpreted, means "he who gets himself up to please the ladies." The last christening was a most unwarrantable libel, probably suggested by

* This has since been pronounced to be of the Duiker species. 
my wearing a bright sash and a Terai hat, but it seemed to give $\mathrm{C}$ - such exquisite pleasure when he discovered it, that I freely forgave all my godfather's for having inflicted it upon me.

A few natives of Kahé, a neighbouring inlabited forest, and a Kiboso man paid us a visit, the latter having been ordered by Sina, his chief, "not to return home without us, as he was anxious to make the white men's acquaintance." The Wa-kiboso are a powerful Caga tribe, boasting, and I believe possessing, over two thousand warriors who inhabit the southern slopes of Kilima-njaro some fifty to sixty miles west of Taveta; they are neighbours of Mandara, with whom they are at deadly enmity. They had only recently made friends with the Wa-taveta, and were rather shy about visiting them, so the way they managed it safely was by picking up a Kahé man or two on the way (the Wa-kahé being mutual friends), and getting him to enlist the services of any Watareta who, at the time, might be visiting Kahé, and then to proceed in company to Taveta.

On February Sth the mail came in, having been delayed nearly five days; so, as by this time all the beads were ready strung, we decided to start on our second trip the next day. These beads were necessarily of all shapes and sizes and varied colours, for there is a wider difference in value between some of the trade beads than there is between gold and silver; a string of one kind is, in certain districts, worth forty times as much as that of another rariety. 
The first day's march was not a very long one, and we only got through nine miles, as it took us nearly two hours to get out of Taveta forest, on account of the delay caused by having to cross six streams with banks, in some cases, very steep. We at length emerged from the south-west corner of the forest not far from the foot of the Pari or Ughono mountains, Kilima-njaro being to our right front. The track immediately before us led through pretty country of open jungle, dotted with dhôm, dwarf, and wild-datebearing palms, in addition to other trees and bushes of variegated foliage, all a pleasant relief to the forest we had been traversing during the previous eight days. We encamped for the night among gigantic trees which formed the outskirts of a forest growth, small in area but magnificent in its strength and luxuriance, a typical specimen, I imagine, of that awful regetation so graphically described and so resolutely attacked and conquered by Stanley at the end of a hundred and sixty days, during his extraordinary march to the relief of Emin Pasha. We hoped to obtain specimesis of the beautiful black and white Colobus monkeys which abound here, but were disappointed. Perhaps it was well we were, for there is considerable risk in shooting these creatures, who, according to the Wa-kahé, are the shades of their departed ancestors. We came across the recent tracks of elephants, and found that these beasts had cleared numerous paths through the dense undergrowth, uprooting small trees and scattering broken branches in every direction. 
During an evening stroll in search of game I emerged on an open plain and tried to stalk some ostriches half-hidden by the jungle, with the result of wounding one with a shot from my $450^{\circ}$ express at a distance of four hundred yards. He went off at full speed with the others, until, unable to continue their pace, he struck out a line of his own and soon succumbed to the effect of the bullet, which had gone through the middle of his body. I found him dead the next day, and he proved to be a fine cock bird in excellent plumage, and though the feathers were not equal in ralue to those of his Cape cousin, I felt none the less proud of my tropliy. We never had much success with the ostriches, and only killed five during the whole time, though we tried stalking and driving. 'J'hey proved more than a match for the most patient stalker, and were nearly always clever enough to choose the safest direction if we attempted to drive them.

The ostrich is a remarkable and by no means ungraceful bird at a distance, but an analysis of his architecture will disappoint the least artistic eye. A short bill, wide, yellow, and dirty, reveals when open a large tongueless carern of a mouth, while round cavities, on either side of the head behind the eyes, do duty as ears; the parody of a tail is matched by a pair of embryonic wings, and a comparatively small head is supported by an almost bare neck of singular length, terminating at the breast in a kind of cushion which is as distinctly useful as it is unornamental. The embryonic wings are mainly clothed with black feathers, which 
are short and tipped with white ones, which are long, in addition to being furnished with dew-claws, and each of the extraragantly long and slender legs terminate in a pair of long toes and a short heel.

Next day we moved some nine or ten miles farther west, until we reached the banks of the river we had already struck on our way to visit Mandara, and here we made an encampment some seven miles farther up, at a point where it changes its course abruptly from due south to east, and continues in that direction to the foot of the Pari mountains.

We all went out shooting parallel to the track, and I was unlucky, although I viewed more game than I had hitherto seen in one day-giraffe, eland, hartebeest, zebra, rhino, bush-buck, buffalo, Granti, and ostriches; but the ground was bad for stalking and all the game very shy. I only obtained one long shot at a bull buffalo, but did not get him; and the bag of all the rest only consisted of a water-buck, a mpallah, and a rhino. We halted at this camp two days, as Martin was laid up with a bad foot, and were out shooting most of the time, but with indifferent success, as the game was so wild. I was particularly unfortunate, as I wounded a very fine bull buffalo out of a herd that we saw making for the bush in the early morning, but failed to secure him, and I also lost a zebra and an eland. To complete my misfortune, I shot at a fine wart-hog, and made a clean miss.

$\mathrm{B}$ - had a great escape in the thick bush as he was picking his way along a narrow game-path bordered 
with high thorn-bushes. Suddenly startled by a crashing of branches, he looked up, to find a rhino charging right down within a few yards of him. He only just had time to put up his rifle and take a snap shot, which luckily took effect just above the beast's eye, bowling it orer like a rabbit-a most fortunate result, as he could not have got out of the creature's way. $\mathrm{C}$ - secured a very good cock ostrich and a warthog, and we caught a great many fish with our Seine net, running from a few ounces up to three or four lbs, in weight, and shot a few spur-fowl for the pot.

Sereral Wa-kahé visited us, bringing a certain amount of bananas, grain, and honey in exchange for meat, which, to our intense disgust, was immediately attacked with knives and teeth and deroured raw. These people closely rescmble the Wa-taveta in appearance, but are less civilised and mostly armed with bows and poisoned arrows.

On leaving this somewhat unlucky camp we mored on about six miles, until we reached the outskirts of the forest of Kahé, our progress being long delayed by a river, the steep banks of which we had to dig away to enable the donkeys to cross it. A great many local natives visited the camp shortly after our arrival, all eager for meat, and unvilling to sell anything for cloth or beads; consequently we were in "Short Street" as far as food was concerned, for Martin, thinking that we could easily keep the cararan well supplied with meat, had brought no reserve. Hand I therefore started off under native guidance to hunt for game, reported plentiful, but my bad luck 


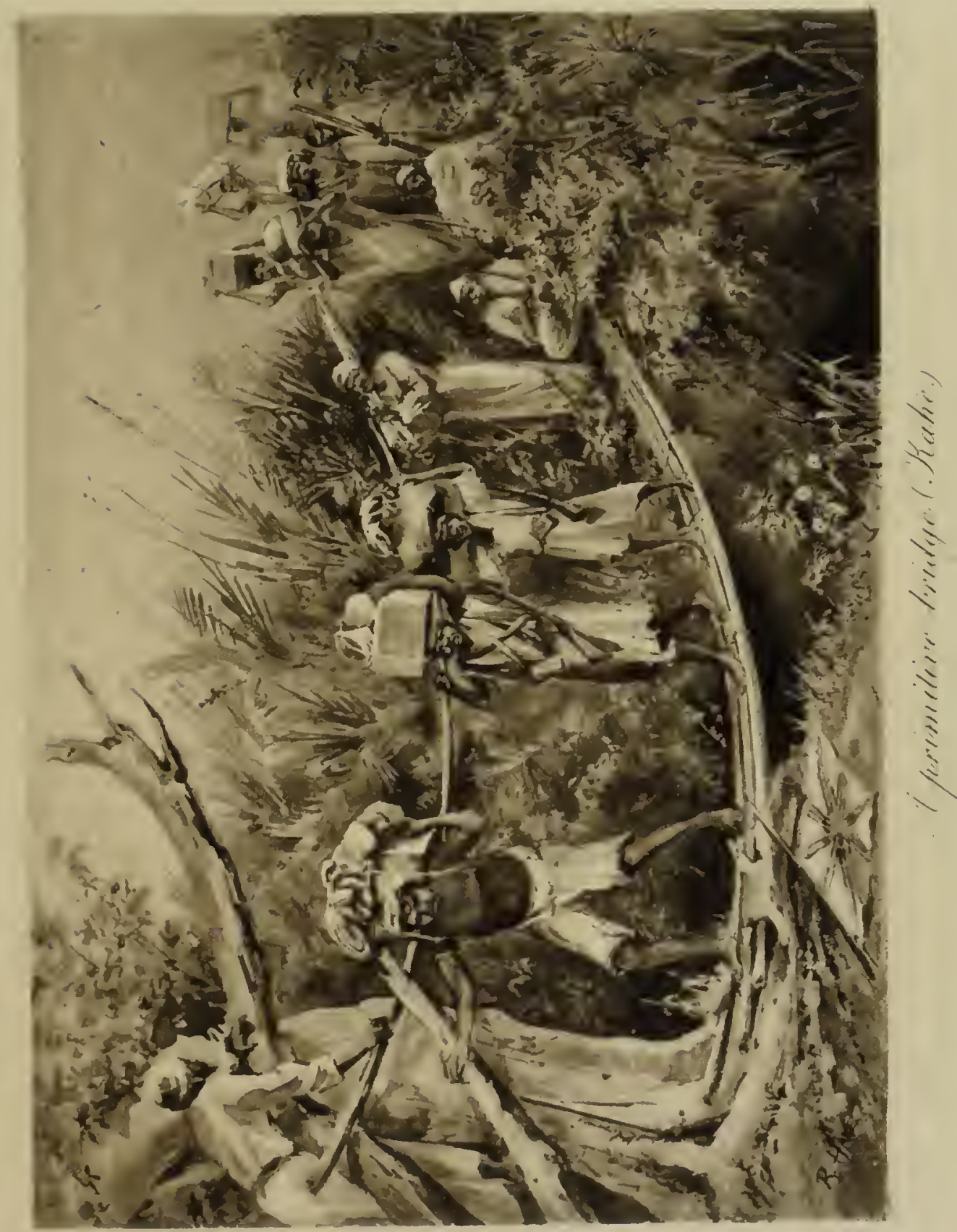



still clung to me, and I failed to fall in with a single head. H_ was more fortunate, and secured three hairtebeest, which kept the wolf from our door for another day. The surrounding soil was distinguished by frequent patches of what appeared to be a rather poor apology for salt, but so highly prized by the Wa-kahé that it is a casus belli in the event of any strangers attempting to collect it.

The women are uglier than their Taveta rivals, and the ugliest are those who adorn their faces with a poudre de ris, manufactured from grease and flour, which is applied in streaks, and gives them somewhat the appearance of clowns. We sent our compliments to the Kahé elders, in the form of a gin and a piece of cloth, though there was no question of hongo, as they and Martin were blood-brothers.

The following day we traversed the forest, which is several miles in length, and, like Taveta, has a great centre clearing occupied by crops of corn and other grain, beans, tobacco, \&c. At one place we came upon a big council of war held by several hundred Kahé warriors about to attack Mandara, who had been stealing their honey-boxes, of which they have a great quantity suspended from the trees on the outskirts of the forest. 'They regarded us with a calm indifference, which was very convenient, and we quite forgave the want of politeness in allowing us to pass without any sign of greeting. Mandara is their deadly enemy, and had recently caught twelve of their men and treated them in a most barbarous manner. 
'The Wra-kahé are not remarkable for great deeds of daring, and may be considered tacticians rather than warriors. Their main object is to successfully surprise an unsuspecting foe at early dawn, and by a sudden pounce to inflict heavy slaughter on the sleeping enemy and capture as many of his cattle as they can. Evidence that the enemy is awake is a sufficient signal for a hasty retreat, accompanied by all the mimic pomp and circumstance of war-doubtless a great relief to their disappointed expectation. I have subsequently heard, and without surprise, that this nation of feeble soldiers has been wiped off the face of Africa by Mandara; and though I grudge Mandara his success, I do not think I ever met a tribe more fitted to illustrate the proverb "Here to-day and gone to-morrow" than that of the Wa-kahé.

Our camp was pitched in a lovely glade, green and grassy, a spot suggestive of perfect peace and goodwill towards all men, and we lolled away the afternoon in weary contentment, until the stillness was broken by a distant hum of angry voices. Twenty of our followers had mutinied and openly declared their intention to return to the coast at once. Arcadia to them meant plenty to eat and drink, and for the last three days they had been almost starving. We succeeded in pacifying them, and sent the Kiboso men, who had stuck to us like limpets, to demand a bullock from the Kahé people in Sina's name. I think these Kiboso natives dared not return to their chief without us, and from all accounts Sina was rather a despot, for not long 
since he had put many of his subjects to deatl for letting out state secrets to the Wa-kahé. He had recently established a kind of mail between Kiboso and Kahé, which probably enabled him to incorporate with it a useful system of espionage.

We heard a good deal of firing in Mandara's direction during the evening, which we were told was the result of a Wa-kiboso attack. Mandara was likely to have a busy time of it, seeing that the Wa-kahé were preparing to surprise him duxing the night or early morning.

During this time of short rations Anole was, of course, living in comparative luxury. Somehow he always managed to beg, borrow, or steal a sufficiency of bananas for himself. On this erentful day he induced a Kahé native to give him an extra supply, on "tick," by the promise of a good hunk of meat from the first animal I killed. I am afraid that confiding Kahé made a bad bargain, as I only succeeded in killing nothing.

We had a very tedious march through bush and long coarse grass the following day, as there was no regular track, and though we zigzagged about for fifteen miles, I don't think we made more than a matter of eight as the crow flies. We halted by a small stream running parallel to the mountain, but which a little lower down alters its course to south-west and empties itself into the Weri-weri river. The surrounding bush was dense, though much intersected by elephant-tracks made during the rains, and $\mathrm{C}-$ had the good fortune to kill a very large bull giraffe, while I got some guineafowl and sand-grouse; so we were able to have a big 
feed. Here we had to remain a day or two and await the arrival of the twenty men we had despatched to Kiboso to bring back a few days' food. Although in parts the game was fairly plentiful, the bush was so thick that we did not do much good. I shot three mpallah and saw two lots of buffalo and a few waterbuck, and a solitary old buffalo jumped up and stood facing me with his head just out of a bush for a moment; but as a head shot is rather uncertain, I waited for him to turn, a movement he executed with such rapidity that he disappeared altogether before I could fire. The elevation of our camp was 2800 feet, and the neighbouring river provided us with plenty of fish, which helped our commissariat a good deal, as the porters were very fond of fish, especially after it had been smoked and kept for a few days.

The men returned from Kiboso late in the afternoon of the second day, bringing with them grain, bananas, a bullock, and a goat from Sina, who also sent a message to say that if we wanted two hundred warriors to help to carry our loads or as escort, he would at once place that number at our disposal. I must say he behared like a "brick" to us in every way, and that too without demanding any hongo; the only present we had sent him hitherto was an infantry colonel's sword and a few trifles of no particular value. He was, of course, most jealous of Mandara, and knowing we had paid him a visit, was only too anxious to cut out his rival and get us to his place. Mandara at the same time was equally anxious to prevent our going 
near Sina, and this condition of rivalry proved to our advantage, as it made either chief strive to outdo the other in helping us. At the same time, I agreed with $\mathrm{B}$ - that our friendliness with both was rather like running with the hare and hunting with the hounds, and not unlikely to land us in a row sooner or later. Sina's people who were with us tried all they knew to get us to go up the mountain and visit their chief at once, holding out as an inducement the prospect of plenty of elephant, kudu, and other game. However, we did not half-believe them, and thought better to first explore the bush and plains we were now approaching. On breaking up the camp we continued our march due west, through thick bush, which after a few days becomes very monotonous, until we reached the Weriweri, and encamped near the widest rirer-bend we had yet come across. There was a large pool close to our camp, full of fish, and H_- declared he saw one quite twenty lbs. in weight. The neighbouring high trees were occupied by a colony of marabout storks, and I shot one specimen for the sake of his splendid tail of greenish-black feathers, orerlying others which are of spotless whiteness and as soft as eider down. II- shot a magnificent bull buffalo in the evening, with a spread between the bend of the horns of forty-one inches, and only ten inches less between the tips. He reported that, after going west for two miles, and crossing the Kikavo, another stream that joins the Weri-weri lower down, he came upon more open ground, and saw four great herds of buffalo. 
Unfortunately our trip to Mount Meru was rather knocked on the head, as some natives reported that, owing to the excessive dryness of the season, the Masai had come down in great numbers to within one short march of our Kikavo camp, in search of fresh grazing for their cattle. Upon hearing this, Martin advised us not to go any farther west, as he said that, with only a hundred men, we were not strong enough to meet the Masai in force, and that even if we were, we should have a great deal of bother with them. This was a great disappointment to us all, as, when we were safely stowed away in the forest of 'Taveta, Martin had assured us we were strong enough for anything, and that we could shoot right up Mount Meru. However, people's ideas are in the habit of being modified somewhat when there is no place of refuge handy in case of a reverse. It was all the more tantalising, as we were apparently just getting into good game-country, and personally I was in farour of going on, thinking that, at the worst, should the Masai prove hostile, we could always run away. We argued the point out in council, and I was overruled, on the ground that the Masai could probably run much faster than any of us; and, perhaps, on the whole it was only reasonably prudent to be guided by Martin's counsels.

We had a day's shooting from our Weri-weri camp, but an interruption occurred in the form of a scare about the Masai. B- and II- had gone west to photograph H_-'s buffalo, which had been left 
out all night, and having got about half-way, discovered a force of some four liundred natives making straight for our camp. Knowing that the Masai (oh, that bogey word Masai! by this time we were quite sick of hearing them mentioned) had been reported close, their gun-bearers naturally concluded the force must be a contingent despatched to demand hongo, and urged an immediate return to make all necessary preparation for their reception at the camp.

I in the meantime had gone out in the same direction, but somewhat to their left, and on ascending a small hill met this imposing force face to face as they were coming up the other side. There was no time to shirk them, so putting a bold face on the matter, though uncertain whether they were hostile or not, I halted my men, and signed to the strangers to do the same; I then adranced half-way to meet their leader, and was somewhat relieved to find he was only the chief of a large caravan of Mandara's men returning from collecting salt in the country of the W'Arusha, a big tribe of degenerate Masai. After shaking hands and commissioning them to bear my salaams to Mandara, we parted with mutual expressions of goodwill, and I continued my search for game, but with the result of seeing only a few zebra, hartebeest, and water-buck.

On returning to camp I found it in an active and excited condition. Sentries on the look-out were posted on erery ant-heap, and Martin had served out extra ammunition and three days' rations to all the 
men, and every one was expecting an almost immediate attack by the Masai. Some of the cowardly porters had already begun to sneak off to hide in the bush, and the general state of tension was snapped by a loud laugh of relief, when I told them how I had interviewed the leader of the supposed enemy, and whom he had turned out to be.

C_- while following the Kikavo river, had wounded a buffalo, but lost him in the bush before the Masai scare. The temporary misfortune was fully compensated for a few days later by the discovery of the carcass and the slaughter of a lion which had been feasting on it.

On the 2oth February we struck camp and followed the serpentine course of the Kikaro river, which, on account of the steep and rocky cliffs forming its banks, can only be crossed at rare intervals. At the end of a six-mile march we pitched our tents on the right bank, amidst a thick clump of tall trees, close to an old camp of IV'Andarobbu, who are the native hunters of these parts. This clump, effectually concealing our encampment and at the same time forming a capital landmark of its whereabouts, was a forest oasis in a surrounding grass and bush wilderness of considerable extent, and here some of us had a very good time with the big game, especially buffalo, while fever was having at least an equally good time of it with the others, including myself. The position of our camp and the proximity of the river, added to the diminished elevation and the frequent rain, were all in 
favour of the game and against the sportsman, but those who were able to work did well.

Our present position was within a short distance of the base of the Sogonoi mountains, an isolated group some serenty miles south-west of Taveta and about thirty miles south of Kilima-njaro. Here we had another mutinous outbreak amongst our troublesome porters; they came in a body and demanded full rations of native grain, instead of the rations of half meat and half grain we had been serring out of late. By way of making them work for their particular caprice in the matter of food, we organised a fatigueparty which should proceed every few days to Kiboso, to obtain exactly what they required, and this decision kept them on the continual trot, to their discomfiture and to our satisfaction.

At the time we were very angry with them, and expected they would soon be clamouring again for meat, for they are like those greedy children who are never satisfied with anything they get. But, to our surprise and disappointment, they did not renew their request for meat for a considerable time. About a month later we discovered the originator of the whole trouble was no other than that horrid old fox, Caěeche, our headman. He alone had indnced the others to rebel; and though we never were quite sure about his object, a dread of the Masai, combined with an inborn love of mischief-making, had doubtless a good deal to do with it. 


\section{CHAP'TER XVI.}

Iy first buffalo-The first lion bagged by C.--Alligators-Surrounded by buffalo-The busli-buck-The W'Arusha-Baboons and wildebeest - Iry first lion-A buffalo and a thino secured with a right and left shot-B. attacked by a buffalo-W'Arusha thieres-Visit to Sina.

I HAD one capital day's shoot from this camp, as in the early morning I secured a very fair mpallah, in addition to three wart-hog, a big sow and boar, and a half-grown porker which I thought would be good for the pot; and later on, after bringing down some splendid rocketing sand-grouse and several spur-fowl, finished up the day's sport before noon with two buffalo. It was just as I was thinking about returning to camp that I caught sight of this last most attractive game standing under a thick mimosa. At first I could only see one, which I stalked through a dry nullah to within twenty yards of his shelter, but with the disappointing result of finding he had disappeared from view. I then left the nullah, and creeping up foot by foot, halted within fifteen yards of the mimosa, until, after a moment of suspense and excitement, out dashed one of the beasts and galloped wildly across the plain in front of me. At a distance of about twenty yards I gare him both barrels of the eight-bore, the first making him stagger, and the second bringing him to the ground on his nose; but he quickly recovered himself, and, to my great 
astonishment and dismay, was soon out of sight. I was about to take up his tracks, when, by a happy glance towards the mimosa, I saw another buffalo standing on the exact spot where I had first noticed the one I had just wounded; so, rushing back and seizing my eight-bore from the gun-bearer, who had reloaded it, I was just in time to put in a couple of shots as the beast bolted out after his mate. He fell over at once, badly disabled, and as he lay glaring at me, with his head well up, I gave him a finishing shot in the neck from my $577^{\circ}$ rifle.

Before I had gone much farther I espied my first quarry lying down, but on my approach to within fifty yards he rose slowly, and facing me, looked exceedingly vicious. I doubt, however, if the poor brute had sufficient strength left in him to charge, though I made a cautious circuit until I got a farourable shot, which put an immediate end to his existence. Both prizes turned out to be fine bulls, but unfortunately the horns of one had been so much worn down that the head was valueless as a trophy. The other was a magnificent specimen, the horns being thirty-six inches inside the widest bend, though, owing to their beautiful inward curves, the tip to tip measurement was only twenty-one inches, while the frontlet was remarkably deep and massive. These were the first buffalo I killed, and I was much impressed with their noble proportions.

The buffalo here stand about sixteen hands, and are about half as heavy again as an ordinary English bullock. The older bulls are almost hairless (though 
the younger ones wear a sleek and glossy coat of black hair), and their horns are strikingly massive, with frontlets almost meeting, and varying in depth from twelve to fifteen inches. In the young bulls this frontlet is absent, the centre of the forehead being merely covered with thick skin and hair. 'The horns are corrugated and rough, except at the extremities, which are smooth and polished, and curve inwards. It is the presence of the massive frontlet protecting the major part of the skull that makes a head shot so hazardous to the sportsman, who, in the event of a charge, if armed with a heary rifle, had best fire at the chest. 'This shot my later experience led me to consider the most deadly. Buffalo, like all other wild animals, are naturally very shy and unaggressive, but, once attacked and injured, become the most dangerous and ricious of any beasts I have encountered. Their habits are the exact opposite of those of the rhino, as they lie up in the thick bush during the day, and only seek the open plains to feed during' the cool of the morning and evening. In the bush they are almost safe from the most skilful hunter, as they inrariably see or hear him first, and taking alarm, plough a headstrong way through the clense corert for miles. The glimpse of a horn or of a tail erect and a cloud of dust is the usual reward of the bestconducted stalk after buffalo in the bush. When wounded in the open they at once make for the thickest covert in the neighbourhood and then face about, and with head down lie in wait for the enemy, 
ready to charge out the moment he appears in sight. 'The object of an attack is an endeavour to first toss the foe as high as he can, and then to kneel and stamp on him. I am happy to say we had no accidents with buffalo on our expedition, though we had many narrow shaves. B-during a recent trip to the same country has been less fortunate, having had several gun-bearers killed by these vindictive animals. He also had a personal escape which was quite remarkable.

As a wounded buffalo charged him, B__ sprang on one side, and the beast's horn just grazed his shoulder, knocking the rifle out of his hand. Before he had time to recover his weapon, the infuriated animal returned to the charge and chevied him round and round a small bush. At length, just as Bwas becoming thoroughly exhausted, one of his gunbearers incautiously showed his head above the long grass in which he had been crouching close at hand, whereupon, learing $\mathrm{B}$ _ fortunate man and wreaked his full vengeance on him, killing him outright. This was indeed a lucky diversion in B-_'s farour, who at once rushed back to camp for another rifle, with which he soon arenged the death of his luckless gun-bearer.

On my return to camp a relapse of fever kept me on my back for a couple of days, cluring which the others shot a rhino, sereral mpallah, wart-hog, and water-buck, which were very plentiful, in addition to a fine lion. This last prize fell to $\mathrm{C} \longrightarrow$ 's rifle, and after a most exciting hunt. IIe came upon it near 
the carcass of the lost buffalo he had wounded some days before, and breaking its shoulder with the first shot, cautiously followed it into the thickest part of a belt of river-side bush, where it had sought refuge. Any farther adrance being injudicious and hardly practicable, he made one of his gun-bearers climb a tree to reconnoitre, and before many minutes the watcher made signals that the lion was quite close. As from his present position $\mathrm{C}$ - could discern nothing amidst the jungle undergrowth, he decided to improve the situation by "shimning" up the nearest tree; and no sooner had he reached a comfortable bough than he looked down upon his quarry crouching within fifteen paces of the spot he had just quitted, and waring his tail in that ominous manner which always precedes a determined charge. After two hours' waiting and poking about, he got in a successful shot as the beast crossed an open space, and was soon afterwards engaged in measuring a skin which proved to be ton feet eleven inches from the tip of the nose to the tip of the tail. C - was very lucky in the way of seeing lions, as he viewed one or more during each of the next four days; but unfortunately he only obtained shots at two, with the result of wounding one which eventually got away. 'This was a great pity, as it was an uncommonly fine specimen, with a splendid mane.

We shot a few alligators, on the river-banks, from twelve to fourteen feet in length, but most managed to scramble or roll into deep water, however hard hit, unless the spine were divided. $\mathrm{B}-$ had good luck 
with the buffalo, as he bagged four or five with very fair heads.

As soon as I recovered from my attack I determined to examine the thick bush on the left bank of the river, and found the spot simply swarming with buffalo. I liept putting them up like rabbits at every few hundred yards, but without getting any chance of a shot. Once I found myself in the middle of a big herd, and to our mutual discomfiture. The beasts dashed off in all directions, and I heard them in front, behind, on my right and at my left, but I never caught sight of a solitary head or tail. Some distance farther on, two charged in their wild career right through my group of gun-bearers, who were within ten yards of me, so I could not shoot without endangering them. Needless to say they let off their rifles, aiming at every point of the compass in addition to that occupied by myself and the buffalo. Horrever, we all escaped, and I believe without the slightest injury.

Some of Sina's men arrived, while we were here, with a present from their chief. Ten of them started on the complimentary visit, according to the account of the three who paid it in person; the excuse for the deficient seven being that they had been charged by a rhino. The reality of the charge I doubt, but, that the original first detachment of ten ambassadors had been greatly weakened by a near view of so dreaded a beast, I quite believe.

I secured a fine bush-buck near this camp, though, from the pace at which it started off after my shot, I 
thought I had made a miss. 'The bullet, however, had smashed the heart and lungs, and yet the poor creature ran right across the open into the bush about two hundred yards distant, and then climbing a small antheap, dropped in his tracks on gaining the summit. 'The bush-buck is a pretty little antelope about twice as heavy as a roe-buck, of dark grey colour tinged with red, with faint white stripes on the quarters and neck; the horns, about twelve inches in length, grow close together and are somewhat twisted.

We killed a few Egyptian geese, beautiful plumaged birds but very tough eating, and some black ibis. I also caught a few fish averaging from one to two lbs., and a silurus weighing five lbs.; I hooked a very heary fish, but did not play him long enough, for no sooner had I brought him to the surface than he broke the hook. I just caught sight of him as he went away, and feel almost certain the creature was a gigantic cel. I wish I had landed him, as I believe, if it had proved to be an eel, it night have been a new discovery, for from the inquiries I made, I am led to believe that eels have been rarely, if ever, found in African rivers.

The last day of our stay here I shot another very fine buffalo, and in rather a lucky way. I walked a long distance without secing anything but mpallah and water-buck, though from a rocky ridge I could view a magnificent plain crawling with zebra, hartebcest, buffalo, ostriches, mpallah, and in the far distance a big herd of eland; but as they were not on my beat, I was 
unable to whet my appetite for sport, and went down to the river to get a drink. While scooping up the water, a splendid buffalo bull jumped up on the opposite bank about serenty yards off, and having only the $450^{\circ}$ express in my hand, I shot at his neck as he was making off. Whether the bullet took effect I do not know, but after floundering about amongst some thick bushes under the trees, he retraced his steps and passed me broadside. With two shots from the eight-bore I broke his shoulder and sent a ball through the lungs; but this was not enough, as he charged down the bank and began crossing the river straight for us. I then gave him another shot, which made him lie down in the water, where, after prolonged bellowing, he expired. He had a very fine massive head, thirty-eight inches across the widest part.

On February $2 S$ th we sent off twenty men to Taveta, to bring in the mail and fresh supplies, which were much needed. 'Then moring some six miles down the river, into still more open country, we encamped on the left bank, as the ground on the right was hilly and much broken. The Arusha-wa-cini lived, we were told, some twelve miles farther down the river, where the Masai had recently arrived with ro,ooo head of cattle. The $W^{\prime}$ Arusha are divided into the Wa-cini (those who live in the lower plains) and the Wa-juu (those who live higher up near Mount Meru), and both are an excessively thieving lot, and not to be trusted in any way. We had the misfortune to lose one of our donkeys about this time; the men said it was from the bite of a 
tsetse-fly; but if that dread fly was about they could not have been in great quantities, as we failed to catch a single specimen. All sorts of others were in painful abundance, and the type of our common house-fly bit uncommonly sharp.

As, with the exception of myself, our whole party were feeling seedy on the afternoon of our arrival at the new camp, I alone went out in the evening, and saw some distant buffalo, which got my wind at once and rapidly made off for the nearest bush. I also came across a colony of large baboons near the river, and sat down quietly to watch their movements. It was rather amusing to see how they stalked me, creeping like human beings about fifteen yards nearer every time, and then stopping to raise their heads most cautiously to sce if I was still there. I remained motionless till one very big fellow, who stood about four feet high, got to within twenty yards, and then I quictly waved one arm; upon this the whole troop went off rapidly with loud screams and barks.

We stayed four days in our new camp, and had capital sport, securing several buffalo, water-buck, mpallah, wart-hog, and steinbock, in addition to a lion. II_- killed one very good buffalo, forty-fire and a half inches across the horns at the widest place, and I obtained a wildebeest twenty inches wide between the horns; he was a solitary bull, and after my shot ran full tilt for two lundred yards before falling dead. It is the most wonderful transformation-scene to see how wildebeest, from being perhaps 
the most ungainly brutes when at rest, become really graceful if fairly extended; their action, when going fast, is easy and even, and the humpy heads give their necks the appearance of being arched like that of a well-bred horse, while their flowing tails stream well out behind. It is, I beliere, from their resemblance to the nobler animal, when galloping, that they are called nyumbu, "wild horses," by the Swahili.

I met Jackson out shooting one day, and learnt from him that his camp was only some seven miles farther down-stream. We sat down on opposite sides of the river and had a long chat and compared notes. He had done pretty well, having killed fifty-five head since January 1, th, including nine buffalo, six eland, some water-buck, wildebeest, mpallah, as well as an ostrich, a leopard, and a cheetah. He told me that he had fallen in with some forty Masai warriors, who appeared to be very friendly, and confirmed the report that they had a large camp and many cattle about three miles south of his position. The heat at this time was very oppressive, generally $95^{\circ}$ in the shade, and the atmosphere was heavily laden with moisture as we had frequent showers of rain and thunderstorms.

I now come to one of my great days, when I shot my first and only lion. I had started out to the left of the river and was skirting the far side of the plain, in the hopes of coming across buffalo near the edge of the bush. As I went along I put up, from under a tree, an enormous leopard, about the size of a moderate lioness, and I put in a snap shot, with no apparent 
effect, as the creature rapidly disappeared. IIaving proceeded about a quarter of a mile farther, I saw some ostriches, and was debating whether I should try and stalk them or not, when one of my men gave a low whistle, to attract my attention, and standing broadside to me, not forty yards away, was a magnificent lion; he was looking at the ostriches, and, like myself, so busy debating the chances of a good stalk, that he neither saw nor heard me. He looked truly magnificent and quite the king of the forest at that moment; but though full of admiration, I lost no time in letting off my $450^{\circ}$ rifle. With a deep roar he bounded off, and fearing that I had not planted the bullet in the right place, I gave him the other barrel. 'Ihis time I aimed for the back of his head, and, as I afterwards found, with great accuracy, though the bullet had only penetrated the skin and then glanced all along his skull, coming out just above the upper lip. As he disappeared after this shot in a thick clump of bush, some twenty yards off, I waited a quarter of an hour before taking up the tracks; I then did not have to penetrate far before I came upon him stone dead, my first bullet having penetrated the heart. He measured nine feet five inches from the tip of his nose to the tip of his tail as he lay, and the skin when remored, without any stretching, measured eleven feet, and that too with rather a short tail. He had a fair amount of mane, which is rare, as it generally gets torn out by the bushes. I was immensely pleased, as I had given up almost all hopes of ever getting a good chance at 


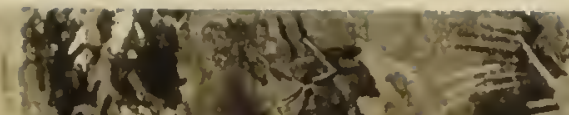

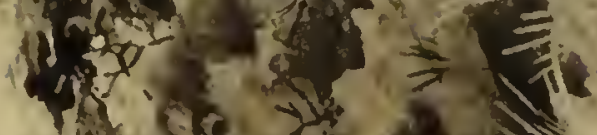

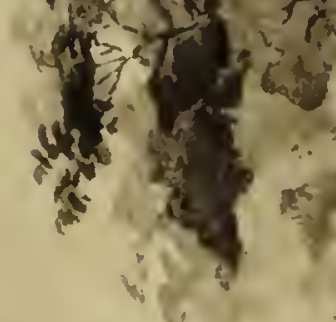

.

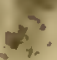
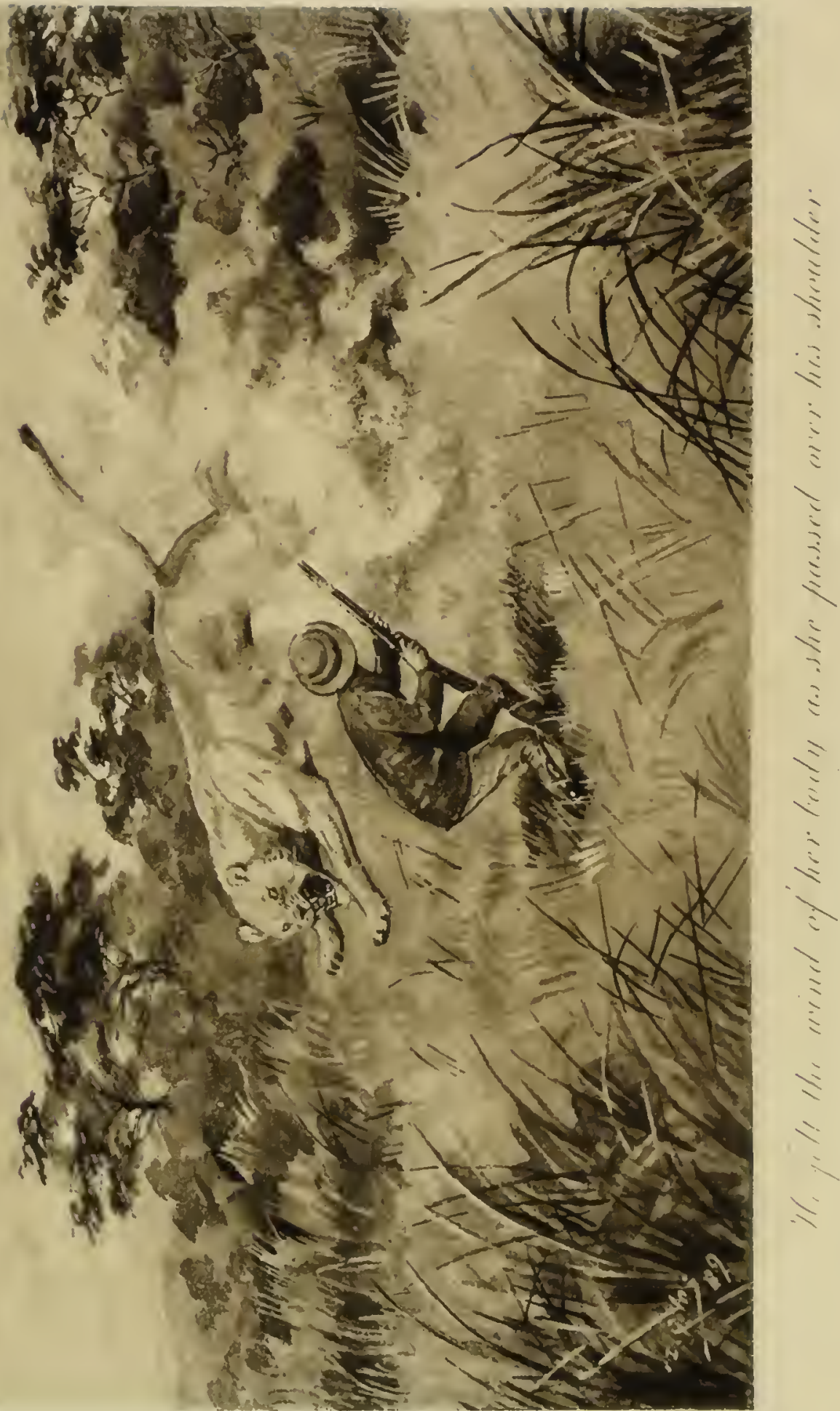
a lion, for it is pure luck stumbling on them in these parts where bush is everywhere thick and rast. I regret to say that, owing to the damp atmosphere, the skin of the body became completely spoilt, but I managed to save that of the head.

Though we only killed three lions during the whole of our expedition, Btunate enough to kill several, though not without having an almost miraculous escape from one. As he only casually mentions the incident in the postscript, attached at the end of this narrative, I think it may prove interesting to give some of the facts as related to me by himself.

He had wounded a lioness and was following her up, perhaps somewhat incautiously, through the bush, when suddenly, and without other warning than a terrific roar, she sprang out upon him from a thick clump. Bfired, and then bent down to see through the smoke if he had stopped her; while in this stooping position, he felt the wind of her body as she passed over his left shoulder, and at once turning round, shot her dead with his second barrel as she alighted after her spring, before she could turn on him again. He had missed her clean with his first shot, and but for his bending down, and the smoke, which no doubt in some measure deranged her aim, she must have caught him.

On returning to camp I found a letter had arrived from Jackson, stating that one of our party had shot so close to him that the rifle-reports had put off two lions he was stalking, and at another time had moved 
some buffalo he was after, and he wanted to know if we could not come to some arrangement which would aroid any such clashing for the future. Of course, we were extremely sorry for the misadventure, and recognising his prior right to the shooting, in that district, wrote back word that we would strike our tents next day.

Accordingly the following morning we moved back to our last camp, which was quite clear of Jackson's beat. 'The others tried to shoot on the ray, but as I was anxious to peg out my lion-skin as soon as I could, I marched with the cararan, and by so doing had a great piece of luck. Having reached the junction of the Weri-weri and Kikaro rivers, I warned Martin I was going on ahead on the chance of getting a water-buck, and I had scarcely proceeded a hundred yards when I discovered a small herd of buffalo in a distant piece of bush. Of course, I began to stalk them, but before I had approached to within eighty yards, a splendid rhino cow crossed the line. Thinking this was clearly "a bird in hand," for which I might well forsake "the birds in the bush," I sent a bullet clean through the heart, and she fell dead.

The buffalo, strange to say, on hearing the riflereport, and not knowing exactly where it canse from, came charging down in a body straight on me instead of making off. I jumped to one side and got behind a small tree, and as they passed exactly over the ground on which I had been standing but a second 
before, I gave the leading bull a shot from the other barrel of my rifle; he staggered on some forty yards and then fell, but quickly recovering himself, moved off slowly into the corert. It was easy enough to take up the blood-tracks, so we followed him, for some little distance, until he suddenly sprang up, from under a very thick bush about fifteen yards off, and, confronting us for one second, charged straight down. I did not give him much time, for before he had come three yards I shot him fair in the chest with the eight-bore, and knocked him over stone dead. This was perhaps just as well, for, had I failed to bring him down, I feel convinced he would have had me, or one of my gunbearers, as there was nothing like a substantial tree within thirty yards of us. He proved a capital bull, with horns measuring thirty-nine and a quarter inches at the widest part.

We then went to look for the rhino, and found her lying in such a natural position, that my men would not believe she was dead, and followed me at a respectful distance while I went up to her. She had, quite recently, been terribly mangled on the flank and quarters by a lion, and great pieces of flesh had been bitten or torn out. I was much surprised at this, and, without the evidence of my own eyes, should have been disinclined to believe that any lion would have thought it worth his while to attack so tough a monster. To bring down a rhino and a buffalo with a right and left, is, I believe, something unique in the history of sport. 
$\mathrm{C}$ - got an ostrich on the way, and B- killed a buffallo that had evidently made up its mind to kill him. He was hunting about in thick bush, when he suddenly heard a grunt and snort so near at hand that it inspired him to make a dash for an ant-heap, about four feet high, that was hard by. In another instant a buffalo had crashed out of the bush and was charging full tilt at the ant-heap. $\mathrm{B}$ - , who had climbed up the refuge, took a shot at his head about eight yards off, but made a miss, and then jumped down from the ant-heap, thinking he would be better able to dodge his antagonist round its base. But this manœurre was completely put out of joint by the buffalo taking the obstacle as a hunter takes a double ditch and hedge, and as he topped the ant-heap $\mathrm{B}$ - had only just time to thrust the muzzle of his $577^{\circ}$ rifle in the brute's face, and press the trigger without putting the butt to his shoulder. Fortunately this shot hit the animal near the eyc, and with the satisfactory result of causing it to turn a complete somersault and fall dead at B__'s fect. On cxamination he found that one foot of this buffalo was in a bad state of mortification, the result of an old wound probably cffected by one of the W'Andarobbu: this must have caused the poor brute much pain, and doubtless accounted for his unprovoked attack on $\mathrm{B}$ -

Later in the afternoon some of the gun-bearers, who had becn left behind to bring in the head, arrived in a high state of excitement, and reported that they had been chased by some of the W'Arusha, and that during 


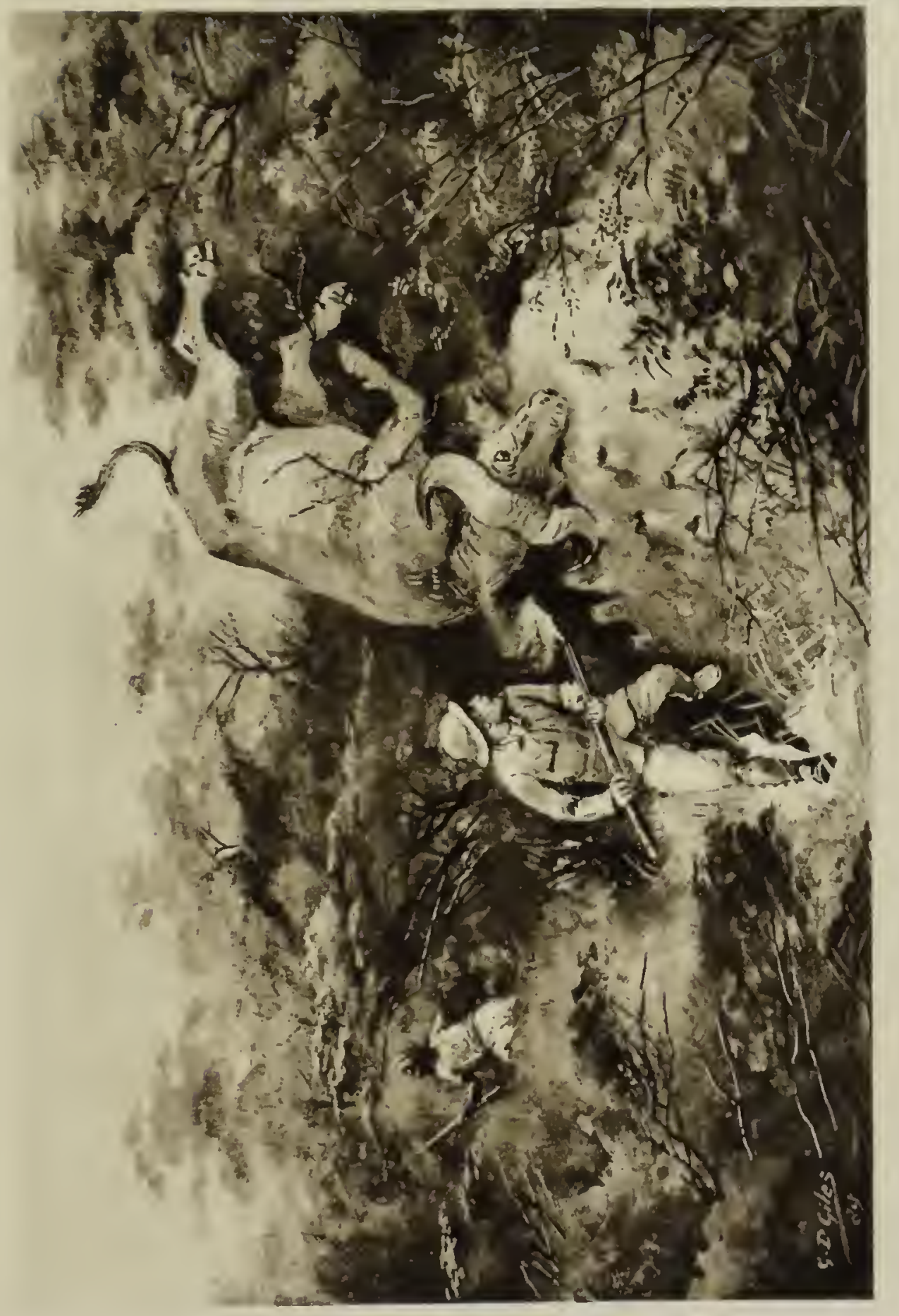


, 
the stampede one of them had thrown away the legs of $\mathrm{B}$ —_'s camera as well as his own rifle with the view to making the best possible rumning. Such conspicuous gallantry clearly demanded some recognition on our part, especially as his comrades declared he had scarcely seen the enemy before he flung down his weapon and his burden, and made off at a splendid pace, shouting loudly that "he was already killed." A reward of many stripes, in the form of an immediate "licking," was followed by a special order that, as a mark of lis distinguished service, he should in future carry the big tent. We then sent off some men to track the W'Arusha and endeavour to recover the lost property, should they prove to have taken it. Before long they came up to three of the stragglers, and seizing their spears and shields, told them they were confiscated until they recovered the missing camera-legs and rifle, and returned them into our camp.

These infortunate wretches appeared before long, bringing with them the camera-legs and some cloth, but no rifle; so our Masai interpreter, deeming this a good opportunity to air his knowledge of the language, harangued away for two hours, and then, conscious of having produced a great impression, awaited the IV'Arusha reply. 'This was to the effect that they had stalked up to our men, and pounced out upon them, by way of having a little innocent fun to relieve the monotony of their march, and at most only desired to produce a slight sensation of alarm. They wondered why our specially distinguished hero ran away, for had 
they desired to kill him they could have done so easily, "although he undoubtedly ran very fast."

These IV'Arusha, who were well-made sarages, had villanous countenances, and weapons consisting of large shiclds and long-bladed spears; we gave them meat and allowed them to remain during the night in our camp. At first I think they were rather afraid of us, but no sooner had they realised that we meant to treat them well, than a native bounce asserted itself and inspired impromptu songs, which set forth how, "if we rentured into their country we should see death long before their meanest herds and flocks, as, having first made us prisoners, they would delight in slaughtering the whole party to a man." They also sang a song specially dedicated to the heroism of B-'s runaway gunbearer, which I hope was translated for his particular edification.

The following morning we marched north-west for about eight miles, and pitched a fresh camp, on a slightly elevated plateau, near the banks of another small stream. Here we stayed one day, and killed two giraffe, two water-buck, one mpallah, and a rhino, and on the evening of our arrival saw a great many buffalo, but the next morning failed to fall in with a single head. 'The surrounding country being unfarourable for shooting, we decided to go up the mountain and pay Sina our long-promised visit, so the next day we recrossed the Kikavo and Weri-weri rivers. During our journey we met a few W'Arusha on their way to interview Mandara, with the object of inducing him to 
join forces against some feeble foe unable to withstand the combined attack. They asked us why we advertised our unfriendliness by making them no presents, to which we replied that we had no desire for friendly relations with a tribe of thieves who had already managed to sneak one of our rifles. During this passage of compliments, one gentleman, who had been watching me intently for some time, quietly rose and endearoured to take the pipe I was smoking out of my mouth; perhaps he thought my face had caught fire, but more probably the attention was suggested by mere inquisitiveness. Anyway, it resulted in a rather rude repulse from me.

Our stores were anxiously low by this time, and we were reduced to grinding corn, as a substitute for flour, by pounding it in a piece of dried skin. However, we hoped soon to fall in with the men whom we had sent back to Taveta for further supplies, and were lucky enough to see them the following night. They had passed our halting-place, which was in a forest of tall trees by a stream with high cliffs on one side, and were ultimately guided back by a smart Kiboso visitor.

On the IIth March we continued the mountain ascent, and reached Kiboso after a very tiring journey, chiefly through a tunnel of dense jungle in which our carriers were unable to march in an erect position. At the end of two hour's' wearisome work we reached the entrance-gate of the Wa-kiboso, a miniature traphole through which we all had to wriggle with such 
loss of human dignity as is contingent on amateur imitations of the grace of reptiles. Our particular debasement was further enhanced by the sight of numerous natives eager to catch a first glimpse of the "white man ;" for, with the exception of Martin, no European had ever visited their demesne. I was surprised at the cleanliness and neatness of the shambas, which were uniformly confined by trim fences composed of squill-like shrubs growing some five feet high, and enclosing the usual banana plantations and plots of ground growing yams, sweet potatoes, mahinde, kunde (beans), and a regetable resembling spinach.

After wending our way for about an hour over many slopes, here cultivated and there charmingly wooded, we arrived near Sina's abode and halted for the whole caravan to close up. The spot we had selected was carpeted with real turf and distinguished by a magnificent tree, something like a banyan, with many of its branches growing straight down into the ground and there taking root. This was, or ought to have been if it were not, the trysting-place for all councils of war.

Sina was evidently becoming impatient about the delay, as he sent down to ask why we did not "come on ;" but, of course, we had to await the cararan before we could enter his stronghold with all due pomp and firing of salutes. When the cararan joined us we continued our advance, and soon reached an elevated platean, just outside Sina's own abode, where that 


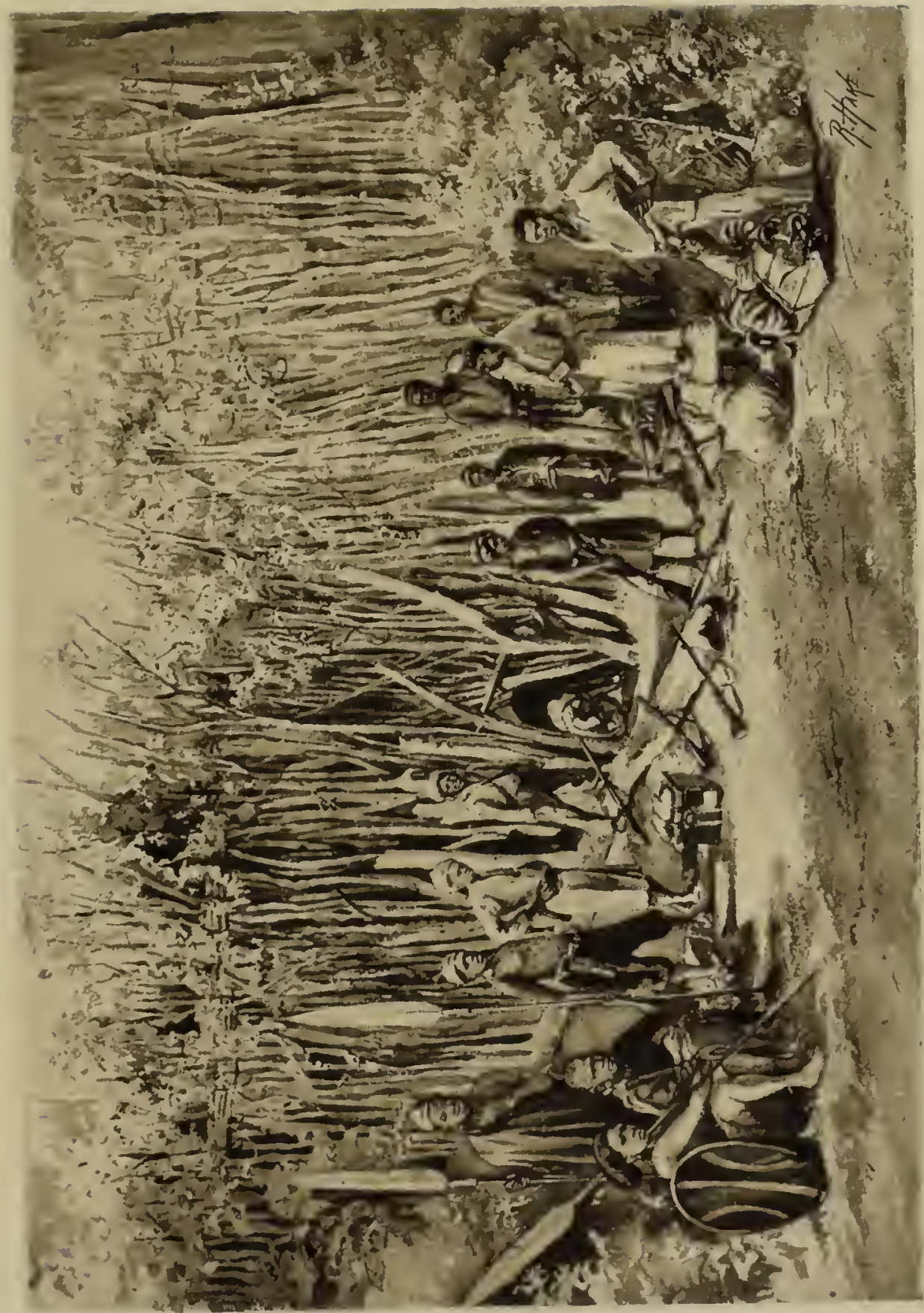



chief was seated in the midst of about six hundred closely packed warriors, anxiously awaiting our arrival. Directly we appeared, they all rose like one man, and adrancing, greeted us with tremendous all-round handshaking, after which we were formally introduced to one of the best-behaved savage chiefs any of us had, up to the present time, been fortunate enough to fall in with. 


\section{CHAPTER XTII.}

Chief Sina-An oath ratified-The bodyguard-Wa-kiboso villagesExtraordinary native engineering operations-A fruitless search for game-A magnificent forest-Ascent of Kilima-njaro-A Kiboso market-place-A false alarm-Fairy forests-The saddle comectingr Kibo and Kimawenzi.

Chief Sina, who seemed shy and nervous, is a stout man about forty years of age, of medium height, with a countenance by no means unpleasing. He was clothed in a flowing robe of striped cotton dotted with blue and red spots and embroidered with beads, and his wrists, neck, and ankles were loaded with copper, brass, and iron rings, and finely-rrought chains, while his fingers were adorned with many rings of a white metal set with light blue beads, producing the effect of turquoises. The head-gear was quite a masterpiece, consisting of a wig, made of interwoven grass and seeds, from which were suspended little ornaments of brass and ivory cut in rings and triangles. He was marmed, but attended by a gun-bearer who carried the old double-barrel gun with which Martin had presented him on his first visit. The warriors were all more or less decorated with iron and copper coils of wire, fine iron chains, beads, and sweet-smelling grass-seed necklaces, the latter somewhat resembling Christian or Moslem rosaries. 'The bodyguard carried spears of 
moderate size and workmanship, short swords and knob-kerries, and large oval shields. Their different methods of doing the hair were curious. Some wore it bound up with grass in short pigtails, here hanging over the forehead and there about the cheeks; while others, having allowed it to grow about twelve inches long, tied it up in a bunch at the roots, from which they plaited a number of small tassels. Others, again, preferred a modification of our own greatest atrocity in the form of a natural head-diess, and built up, with the aid of an extra amount of grease and clay, a chignon which might have made the reputation of any European artiste a few years ago. This some of the more particular dandies protect with a skin bag during inclement weather. Their countenances, though ugly enough, were good-natured, and the ears were disfigured by stretching, and the teeth, in many cases, filed.

After greeting us cordially and delivering a few polite sentences of welcome, the chief, with the best of manners, retired with all his men to a distance of about two hundred yards, to enable us to pitch our camp without impediment, and there, squatting on the ground, waited patiently till that performance was completed, before returning to settle themselves in a compact semicircle round our tents.

Amongst the crowd were a few W'Arusha and Masai, who had come to effect a treaty of alliance with the Sina. We therefore seized the occasion to state how some of their countrymen had treated us, and asked 
them why, if they wanted to take our rifles, they did not come boldly up to the whole caravan, instead of sneaking after a few wretched stragglers. A great deal of oratory on both sides ensued, and, to impress them, we burnt two Pharaoh's serpents, declaring that their country should be infested by similar reptiles if the lost rifle was not returned. The Masai then abused the W'Arusha, telling them they had no business to annoy us, and so stop trade coming into the country! 'This I thought not bad for the Masai, considering they do more harm to trade, in these parts, than all other tribes put together. After these preliminaries we made them swear to get the rifle back, the oath being ratified by Martin, and the head-men of the Masai and W'Arusha, assisted by our interpreter Esa-Moussa, who in turn stepped backwards and forwards over a spear, swearing hard all the time. At the end of this performance Martin shook hands with the leading Masai, and they spat on each other as a convincing proof of everlasting friendship.

'These Masai did not seem bad sort of fellows, and were all six feet in height or over; their features are totally different to those of the Kilima-njaro natives, the faces being distinctly oval, with high prominent cheek-bones and slit-like eyelids, slanting downwards and inwards, like those of the Japanese. 'Their clothes were of the scantiest description, and their ornaments consisted of coils of fine chains of iron and copper wire, unrelieved by the beads affected by other tribes.

Sina presented us with two goats and two bullocks 
for our men, and said that everything he possessed was at our disposal. The people were very orderly, quiet, and unobtrusive, and agreeably free from that native curiosity which, elsewhere, we had found so tiresome. The afternoon of our arrival was taken up by frequent audiences with Sina, who would stay an hour, and then depart, to refresh himself with pombé, but only to return for another hour's chat; I think he looked upon us in the light of a set of new toys. We tried very hard to obtain information about the local mountain game and its whereabouts, but this was rather a difficult matter, as none of the interpreters seemed to know the Kiboso names of the animals. However, we made out that there were elephants and kudu within a two days' march, higher up, and that there was also any amount of varied game two hours west of our camp. This was rather prettily situated on a grassy slope affording abundant pasture to numerous goats and sheep, and leading to a steep ravine that overlooked a small river. The surrounding slopes, above and below, were cultivated, while the forest in the far distance formed a dark green frame to the general landscape. I was surprised to find that the women were not allowed to visit us; our camp was unadorned by the presence of feminine grace and beauty.

We witnessed a native dance, in the evening, which must have involved very hard work, as it chiefly consisted in the dancers, who were stark naked, jumping as high as possible, with bodies rigid and heels kept close together, and wagging their heads as though they 
were trying to shake them off. 'Their long hair, flopping about like mops, distributed the grease and red clay in all directions, while they kept up a monotonous chant which was rather depressing. 'The performers were all picked men of Sina's bodyguard, which is changed every few days, three hundred being required to surround his abode each night.

Although a powerful chief, with about two thousand warriors under his command, Sina is always in fear of being attacked by some of his enemies. Ile presents a bullock to the bodyguard, at the end of their term of duty, upon which they feast directly the relief detachment arrives. Every morning we were awakened about 5 A.M. by this bodyguard, which at that hour went through a sort of field day and drill, the latter manœurre being remarkable for its simplicity. 'They yelled a good deal, and brandished their spears and guns, and made a series of short rushes, advancing and retiring en masse up and down the slopes, those carrying guns occasionally firing them off in the air, while the spearbearers crouched under their shields and held their weapons in rest. On account of these performances we became very early risers, as it was hopeless to try and sleep for a second after 5 A.M.

At night we let off some rockets for the edification of the multitude, and Sina was in raptures when we told him that his enemy and neighbour, Mandara, would see them, and at once guess that we were staying with him. Our present to Sina consisted of two Snider rifles, with fifty rounds of ammunition, and 
a load of fancy cloth, besides little odds and ends and sixty gun-cartridges, which I think he prized most of all.

Among the products of the country, that I have not mentioned, were sweet potatoes, a kind of tapioca, beans, and excellent clear honey; the stock consisted of sheep with fat curly tails, bullocks, and goats, and I should say the people represented a happy and prosperous community, with very little work to do, and plenty of time to do it in. The huts in which the Wa-kiboso live are neatly made of banana-leaves, and shaped like beehives; each is enclosed by a strong palisade, some two to three feet thick, of thin poles stacked together, and enclosing a rectangular space. ${ }^{*}$ The main village is formed of a succession of these palisaded enclosures running into each other, the means of communication being a narrow gateway, across which can be drawn at will a sliding door consisting of a heavy slab of thick wood pierced with loopholes, so that the whole forms a real stronghold, almost impregnable against hostile natives; I should say it would prove a tough nut to crack even for a European force unprovided with a mountain battery.

We paid Sina one or two visits inside his fortress, and examined the excavations he was making, at this time, which were really wonderful, and proved him to be no mean engineer. His object was to undermine

* A considerable portion of the stoeliades consist of green saplings, three inehes in diameter, planted elose together, the interstices being filled in with diried ones. 
the whole village with enormous caves and long underground passages, which should represent a place of refuge for the cattle and the women and children, in the event of any sudden attack being made. He had established a law to the effect that any man who took refuge below, instead of remaining above to repel the attack, was to be punished by death.

The excavations were being executed in the following manner: a series of shafts from two to three feet in diameter were sunk some twenty to thirty feet, and these were connected, by underground tunnelling and excavating, until a succession of large caves and passages were formed, the latter being about eight or nine feet wide and seven or eight feet high. As each excavation was completed, the surface of the original shaft-hole was filled in with earth and sticks, and a little point of ivory stuck into the ground, with the double object of marking the spot and acting as a charm.

'The whole of this laborious engineering was being executed with the aid of a single tool in the form of a crow-bar made out of the barrel of an old gun, and with this ineffective implement they managed to bore through the volcanic rock immediately underlying the surface-soil, specimens of which I brought away with me. The loose earth and rock débris were conveyed to the surface from below by means of wooden boxes attached to long whip-like stems, of requisite length, tied together. At the time of our visit this stupendous undertaking, though considerably advanced, 



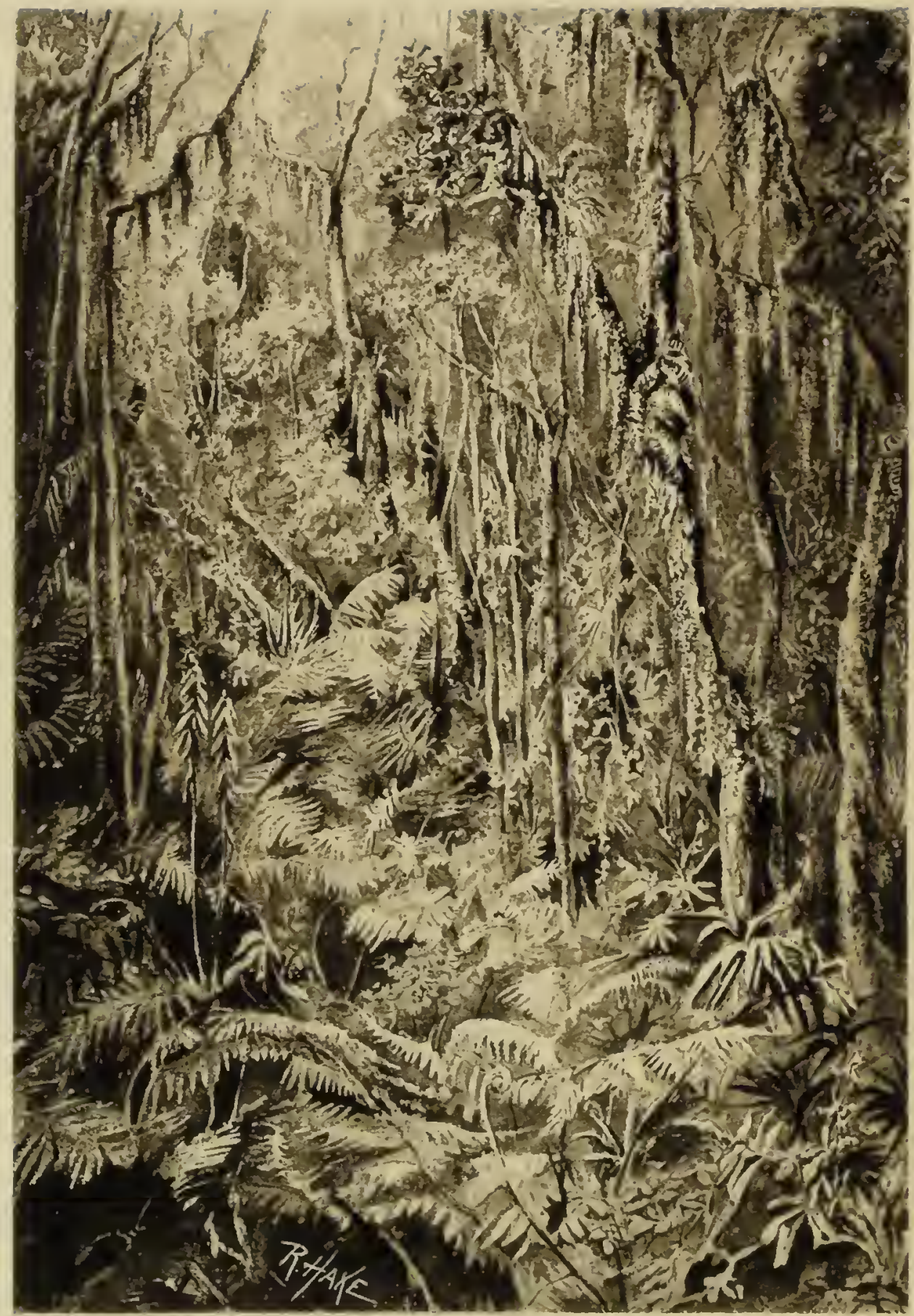


was likely to prove an heirloom to be completed by a succeeding generation.

'The Kiboso language, a dialect of the C̆aga tribes, was unintelligible to Martin, and we became entirely dependent upon our two interpreters, Esa-Moussa and Kičaga. Sina made us a present of a very fat sheep, by way of making up for the misfortune of our having been unable to join him in a bowl of pombé when we forwarded our first gifts. I was told, however, that our ten enroys who conveyed them acted as our proxies to their utmost capacity, and did full justice to the beverage placed before them.

While here, I engaged a few of Sina's men and went in search of the game declared to be so plentiful about two hours' journey west of our camp, which was 4400 feet above the sea-level. After crossing a series of six small but very steep ravines, and passing through many shambas and banana plantations watered by storage reservoirs in connection with artificial channels, we came to the edge of the thick forest, where I was informed we must arvait the arrival of some natives living a considerable distance off.

We had then been marching for one hour and a half, so I hazarded the hope that we were now within half an hour of the game-country. 'The reply, though not altogether surprising, was most unsatisfactory, as from it we gathered there was no chance of seeing a head of game within a distance that could only be covered by a six hours' further march. Though all my previous experience had taught me to distrust the native 
idea of distance, I was loath to believe that Sina would have said the game was quite near if it were a good day's journey distant, so I decided to carry on the exploration for another hour or two.

We accordingly penetrated the forest, which was quite startling in its beauty and magnificence. I had never seen so many tall trees together before, some of them being from eighty to a hundred feet high before branching. Vast creepers hung like green ropes from their lofty branches, while every variety of foliage and every shade of green, with many ferns of all sorts, from the gigantic tree-fern downwards, were interspersed with rank undergrowth and bright flowers. This forest was alive with dark blue pigeons, hornbills, trogans, and many other kinds of birds, but we saw no sign of any four-footed beast. Having marched through the forest for two hours, much against the will of my men, the Wa-kiboso, who were to follow on and catch us up, arrived, and it was then explained that they had come provided with enough bananas and sweet potatoes for a week's outing! On further questioning they declared that if we wanted to see game we must sleep out, an arrangement for which we were in no way prepared; so I reluctantly gave up the pursuit, feeling much annoyed at having been led out on such a wild-goose chase.

On the way back I.met several women, who all fled precipitately from me as if I were a wild beast. From the glimpses I caught of them, they seemed to have nothing on but a small tassel of beads tied round the 
waist. One distinctly clay-coloured damsel, of most ample proportions, nearly fell into my arms as she was hastily rounding a corner, and with a little scream just managed to save herself from being saved by me, and then "flopped" away with an agility which was more remarkable than graceful.

After a two days' rest in this land of plenty, we made an early start, with the view to ascending the heights of Kilima-njaro in the double capacity of sportsmen and mountaineers. Just before we left, Sina held a political meeting on the advisability of accepting the hand of friendship, now extended towards him by the Masai and W'Arusha envoys, which resulted in his sending a present of iron chains to the Masai, in token of his willingness to make a treaty with them and with them only. The overtures of the W'Arusha had been declined, as he afterwards told us, for the simple reason that his cabinet agreed with him that they represented a blackguard tribe, quite unworthy of being trusted and capable of the grossest form of treachery, under the guise of a pretended desire for friendship.

On leaving the camp we had a most tedious march through the cultivated portions of Kiboso, crossing no fewer than nine steep ravines without attaining a higher altitude than 4800 feet. The last ravine was a real stiff one, for after an almost perpendicular descent of Iooo feet, we had to make an equally steep ascent of its opposite incline. Having accomplished this, we encamped for the night, and discovered the disappointing fact, that after marching for seven most tedious 
hours, we had placed a bee-line of something less than six miles between us and the encampment we had last left.

During this wearisome journey we overtook numerous ladies on their way to market; and though too wearied to feel critical about any particular style of dress, the absence of anything which represented even the simplest form of covering enabled me to record the fact that many of the younger Kiboso ladies had most attractive figures. Later on we passed the market, their destination, a rookery consisting of some five hundred ladies bent on eager commerce, and yet capable of an almost complete silence during the time occupied by our passage-a remarkable instance of feminine self-control, deserving a record of infinitely greater significance than mine, and an example that might well be followed by many of the fair sex nearer horre. I noticed that the natives, who guided us, whistled on approaching any woman, as a signal for them to get out of sight, if possible; on hearing the whistle, if there were a gap in the hedge alongside the path, the dusky damsels would dart through it and remain in ambush until we had passed.

About half-way we met an unexpected chief, one of Sina's natural sons, who is a sort of sub-governor of this part of his father's dominions, and was rery conspicuous in his bright red robe. At first he wanted us to stop the night there, so that he might liill a goat and make brothers with us, as he said he would be afraid of us until he knew us better. We escaped 
the delay entailed by this proposed ceremony, by saying that we had a long way to go and must hurry on, but that possibly on our way back we might see more of him; so with some reluctance he provided us with guides and gave us a present of twenty loads of bananas and a goat.

In the night we had a slight excitement, as about 2 A.M. some of our men roused us with the information that a force of natives were approaching from Mandara's side, and we certainly did hear a good deal of shouting; but it turned out to be a false alarm, as it was only caused by some of Mandara's scouts or vedettes, who, seeing our camp-fires, thought the Wa-kiboso intended to attack them, and were raising the war-cry of "Womé! womé!" ("Men! men!") to warn their people. We therefore sent out Kiěaga and one or two men to allay their fears, and to let them know that it was only our party going up the mountain.

The following day we had another stiff march, all against the collar, up to an elevation of 8800 feet, through the most curious and beautiful forest imaginable. At the height of 5400 feet the cultivation ceased, and we passed through a wide tract of low bush intermingled with a good deal of the homely fern and bracken. 'The denser forest here commences at a height of about 6000 feet, and, the atmosphere being excessively damp, the trunks and even the branches of nearly all the trees are covered with various mosses, while gigantic creepers, ferns, and flowers of every variety combine to produce a most fairy-like effect. 
I was disappointed to find the orchids were not in bloom at this time of year, but some of the flowers were lovely. We saw no animals on the march, but once came upon some fresh elephant-tracks crossing the path into the impenetrable jungle, on which the passage of even those leviathans had left little impression. The silence of the dead reigned here unbroken by the note of birds or the hum of insects, and even our porters seemed impressed with this unusual phenomenon, and refrained from breaking the solemnity of the awful stillness with the usual amount of shouting and singing.

At last the aspect of this somewhat melancholy though beautiful forest changed, and at a height of 8800 feet we encamped in an open grass glade about a quarter of a mile square. At this point the larger and more massive vegetation is replaced by innumerable slender trees, closely packed and about twenty feet in height, with stems only a few inches in diameter. 'They are clothed with light grey moss, hanging like icicles from their spectre branches and producing a strangely weird and chilly effect These curious trees are, I believe, a variety of gigantic heath with bushy tops; they apparently have a hard struggle for existence and were more than half-dead, as their stems were so rotten that we could break them down like paper as we walked through them. The grass was also very weak and much resembled the herbage found on the high hills of deer-forests in Scotland, and was here and there patched with clusters of the common pink "everlasting flowers." 


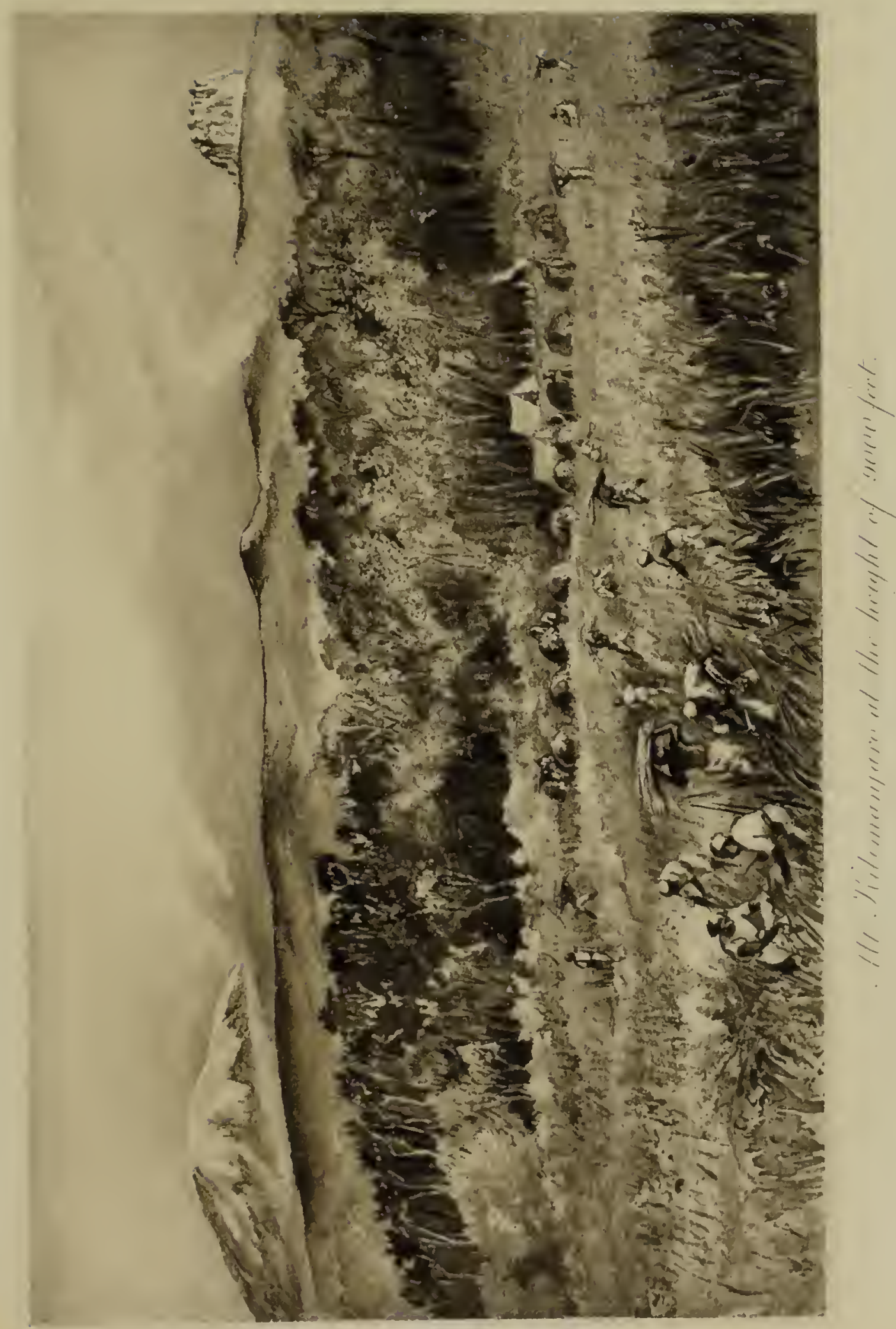



As we had got a long way ahead of the caravan, we had to wait here for three hours before our tents arrived, so all four of us sat huddled together under one mackintosh and a white umbrella, while frequent cold showers of sleet and rain did their utmost to chill our very souls, and tended to damp our mountaineering ardour, until, by good luck, a load arrived, out of which we were able to get a bottle of port.

The thermometer next morning registered only $38^{\circ}$, rather a sudden change from the $95^{\circ}$ in the shade of only five days ago. I was quite sorry for our poor men, as they had nothing but their linen garments to keep out the cold. My servant Anole was in a particularly bad way, as, excepting a small waistband of cloth, he had parted with all his clothes in exchange for extra food. Forgetful for the moment of this insatiable gluttony, I gave him a piece of cloth as an extra covering; but although shivering and miserable, nothing would induce him to convert it into a garment, as he meant to sell it for food when we got back to the plains, and cutting it up would decrease its value.

After half an hour's march, next day, through the grotesque heath-forest, we emerged upon a most beautiful undulating and park-like country, intersected by small rivulets and watercourses, with here and there a coppice of trees or patch of jungle. These charming slopes were bounded below by the irregular edge of the forest, extending east and west for many miles, while far above us could be seen a large tract of short scrub and heath, broken in places by rocky cliffs and 
massive boulders, the whole landscape reminding me of some of those half-rild parks to be found in the north of England, though, of course, on a grander scale. Here we pitched our camp, at an elevation of 10,000 feet, in a little hollow, sheltered from the keen northeast wind by the brow of the hill above and by a small wood below. TVe passed the afternoon in a fruitless search for game declared by the natives to be abundant, and particularly attractive to the sportsman on account of its variety. We certainly came upon two little grey antelope, about the size of roe-deer, but, as we failed to obtain either of them, I can only hazard the probability that they represented unknown species of the Duiker class.

The following morning the thermometer gave us the chilling information that the temperature was two degrees below freezing-point, a meteorological fact we had almost grasped when we found the water in our buckets lightly frozen over and our men surrounding a number of brilliant fires. From these groups we extracted our interpreters and Kiboso guides, who, with chattering teeth and shivering limbs, assured us that, a short time before our arrival, these frigid heights had been the particular rendezvous of all kinds of game, and suggested our making an immediate tour of inspection around, with the view to finding its present whereabouts. Our experience during the previous afternoon and our present ability to spy out the nakedness of the land (as far as game was concerned) for many miles, decided us to decline their 
advice, and to sacrifice the hunter's instinct to that of the explorer. We therefore determined to continue the mountain ascent, and to try and reach the saddle connecting our intimate friends and landmarks Kibo and Kimawenzi, a goal apparently not too far distant to be within easy reach, but which, like most mountaineers' goals, proved remarkable for its attractive deceptions.

No sooner had we captured what appeared to be our last mountain ridge, than we found ourselves confronted by the "last but one," until we almost accepted the existence of any individual ridge connecting the two peaks, as a geological "Mrs. Harris." Fortunately the ascent was gradual, and the going fair enough as long as we picked our way clear of the rocks and boulders and thick patches of coarse heath and grass, in places, about four feet high.

At I 2.jO P.M. we united our forces, and, making a big fire, halted for a short time at an elevation of 14,800 feet; here most of our gun-bearers gave in, being quite beat and complaining of giddiness and headache. After resting arwhile we continued the ascent, each taking his own line; at about I 5,000 feet the scrub and heath, which had become scantier and more sparse as we proceeded, disappeared altogether, and I came upon a sloping plain of soft and friable volcanic soil, with here and there mounds and patches of shale and ashes. At this height, it was very fatiguing on account of the rarefied condition of the air; however, I persevered, and dragged my weary way up this slope for 
about two miles to the foot of a small hill situated half-way between Kibo and Kimawenzi. This hill, rising about 400 feet in height above the surrounding plateau, is composed entirely of loose ashes and lava rock; and as the southern side was too steep to climb, I passed round to the left where the plateau began to slope gradually down northwards, and here I ascended the small hill on the north side, which, though steep, was practicable, and from the summit of which my aneroid registered I 5,500 feet; but I think the more probable height would be 16,000 feet, as I doubt whether my aneroid was quite reliable at such an elevation.

The ashes forming the chief part of the hill-soil were red, but they were streaked here and there with others of grey, blue, yellow, purple, pink, and orange tints. I made a small collection of the different specimens, and amongst others I gathered some of a black substance not unlike lignite; the variety in the colours is due, I believe, to the action of the sun and atmosphere, combined with the different degrees of heat to which the ashes were originally subjected.

I was much disappointed to find the mist so dense on this side that I could see nothing of the northern slopes of the mountain, and while referring to this mist I may mention that during our stay, on the higher slopes of Kilima-njaro, we rarely saw the sun, as it was nearly always concealed by an impenetrable veil of overhanging clouds. An excessively cold wind swept the mountain-side, and I was glad to sit down, under the lee of some curiously fan-shaped lara rocks, to examine 
with my telescope the interesting summits of Kibo and Kimawenzi. The latter is apparently a mass of black and broken rocks, culminating in numberless fantastic pinnacles and needle-points partially covered with snow, and forming an almost unique study in black and white. Any ascent appeared to me to be quite impracticable. Kibo, on the other hand, is of much greater circumference, dome-shaped, and certainly practicable up to about I 8,000 feet, or perhaps even a little higher. Beyond that elevation I think it would be impossible to climb by either the southern, eastern, or north-eastern sides, as any passage is apparently barred by abrupt cliffs and precipices, and, still higher up, by almost perpendicular walls of solid ice and snow, some hundreds of feet in height, before it again gradually slopes upwards for a few hundred feet towards the mouth of the crater. The intervening shelving spaces below the glacier are covered with loose shale and volcanic matter.

I may lay claim to having ascended beyond the first snow-line, as there were two small patches of snow on this hill about a hundred feet immediately below me. The saddle between Kima and Kibo is a sloping plateau, some four miles wide from the points where Kibo on the one side and Kimawenzi on the other begin to rise precipitously. On this plateau are, scattered about in all directions, high blocks of rock, many weighing several hundredweight, which suggested the idea that Kibo must have suffered badly from indigestion before getting rid of 
them. Altogether this mountain is marvellous in its grand proportions, and I wish I could give a description more worthy of it. The sloping plateau above I 5,000 feet is almost devoid of vegetation. An occasional tuft of dry and blackened grass, a few small plants bearing a little white everlasting flower, and a few thistles growing in circles, the centres of which are bare, testify to the poorness of the soil, though on Kimawenzi I discovered in one hollow, where the snow had melted, a patch of bright green grass. I was surprised to find in the most sterile part of the plateau traces of a large antelope, possibly a kudu, though what could have attracted him there I know not, unless the saddle is used as a pass by game in the habit of shifting from one side of the mountain to the other, during certain seasons of the year. When I had completed my observations I descended the hill, and rejoining my men as quickly as I could, at once took some photographs of Kibo and Kimawenzi, though the operation was much impeded by the sweeping mist which completely enveloped them at times. I much regretted that my men were unable to accompany me to the highest point reached, and thus enable me to take photos at that altitude. We then made a start for our camp, which we did not reach till 7 P.M., so we had a pretty long day of it."

* Our original idea was to attempt the final ascent of Kibo, but this we had to foregro, as it would have been eruelty to have kept our men, scantily clother as they were, for any length of time in these eold regions. While writing this narrative I have read, in the Times, an account of the aseent of Kibo professed to have been sucecsfully necrotiated, by a German who asserts that he reached to within three hundred feet of the summit 
The erening was chiefly occupied in a great discussion as to where we should go next; my plan was to proceed east and descend the mountain to Useri, which would enable us to explore thoroughly the higher slope on that side and to shoot our way back to 'Taveta through good game-country. Failing this, I proposed to descend to Lake Cala, which was much the nearest way to our headquarters, but I was overruled by the others, and we decided to return by the way we had come and to pay Sina a final visit, as we thought we owed him this civility on account of his kind behariour and liberality towards us.

The Wa-kiboso, with us, were very pleased when they heard that we had had enough of the mountain; I must say they were capital fellows, and bore the cold wonderfully well, considering their only clothing consisted of a small piece of cloth and a little leather apron fastened round the waist and hanging down behind. They were in a great state of mind lest we should be lost up the mountain, and lit fires on all the ridges, round our camp, as beacons, and on our return shook us warmly by the hand, and danced with delight when we told them that they should all have a present of cloth for their trouble. Many of our men, especially the

before being stopped by a wall of iee that barred further progress. I think he must have been deeeived in the aetual height he attained, as with my teleseope I conld well make out the glacier he mentions, and I estimate it as being fully a tlousand feet in depth; therefore $I$ think he eamnot have reached nearer than within a thousand feet of the summit. I have still more reeently heard, on the best authority, that another German lias suecessfully reacher the summit, having diseovered an easy way of aseent on the northwest side. He reports the discovery of a large erater eloked up with eternal 
Indian servants, were down with ferer during the time we were encamped in the higher altitudes, and I believe the sudden change from heat to cold is not an uncommon factor in the production of ferer.

We marched back to Kiboso in two days, the time occupied in the descent being just half that required for the ascent. Altogether in three days we did 22,000 feet up and down, without counting the ascents and descents of countless small ravines, and by the time we got back to Kiboso we had had quite enough of mountaineering. On the way back we found our friend the small chief waiting to intercept us, and of course anxious that we should remain with him for the night; but we told him it was impossible, as Sina was, even then, expecting us; so, with no attempt to conceal his disappointment, he gave us another goat, and made a very humble speech to the effect that Sina was a great man, while he was only a small chief and a very ignorant one, and that he was afraid his presents were not good enough for us, but that if only we would spit upon his hand he would be happy, and perhaps some day become a wise man. This we all did, promising at the same time to send him back a present from our camp at Kiboso, and then left him in a supremely contented mood.

On our return to Sina, we found him looking very ill and yellow, as he had been suffering with fever for some days. He was, of course, holding a conclave as usual, for some more W'Arusha had come in to try again to make friends with him. These W'Arusha 
were rather a nuisance, as, not content with staring from a respectful distance, they came and squatted inside our tents, and of course begged for everything. Had they been as odourless as they were mannerless, we should not have thought of presenting them with the smallest gift, but by way of getting rid of such high-flavoured beggars we distributed a few matches amongst them. We stayed here one day, in order to get some milch goats which Sina had promised us, and as it rained rather heavily, $\mathrm{H}$ _ was down on his back with a fresh bout of fever.

The site of our encampment, I found out, had been the scene of a tragedy, as shortly before our arrival Sina had here massacred one of his brothers and thirtyfive men, because he thought they were conspiring together to kill him and usurp the throne. Before taking our leave I prevailed upon him to allow me to photograph him, by saying it was a prevailing custom among all the kings in our country. I included Martin in the photograph by way of giving Sina confidence, and no sooner was the operation over than all his headmen wanted me to perform upon them; this I did, though unfortunately the results were not very successful.

On the 2oth of March we bade farewell to Sina, and turned our backs on the heights of Kilima-njaro. IVe had a long journey, for when we arrived at the Ziwa, where we had halted on our way to the Kikavo river, we found its bed completely dry, and therefore had to march on until we came to our old camp on the 
banks of a stream considerably to the east of the Weriweri, and consequently we did not get the tents pitched till past 2 P.M. Thus ended our visit to the kindly chief of Kiboso, and our ascent of Kilima-njaro, a most interesting and instructive experience, to which I shall always look back with pleasurable sensations. 


\section{CHAPTER XVIII.}

Elephants-A novel cure for a headache--A successful snap-shot at a buffalo-Abundance of game on the Abarri river-Wart-hog and eland-Return to Taveta-Revisit Lake Jipé.

There was not much inducement to remain here, as the bush was thick and the game not over plentiful, so we marched on due east for another two hours. We came across numerous fresh tracks, which proved that elephants were evidently on the move and coming down from the mountain, a fact which decided us to halt here for a few days, especially as some of our men, who had been sent out shortly after our arrival to explore the proposed road for the following day, reported that they had come upon a herd of twenty beasts with some fine tuskers amongst them. Personally I was very glad of the halt, as at this time I was suffering from a bad attack of fever, and was, indeed, hardly able to move for several days.

The other's fell in with water-buck and wart-hog, but did not shoot, for fear of disturbing any elephants that might be in the neighbourhood. In this part of the country, the jungle was very thick in some places, and swampy in other's; so, although there was every indication of the existence of elephants, B- and Cwere the only two who saw a single specimen, a very fine 
tusker who unfortunately winded them and made off before there was a chance of their obtaining anything like a fair shot.

At the end of these few days of fruitless search, as I was somewhat better, though still very weak and pulled down, we struck camp, and after a march of some three miles came upon a small herd of giraffe, three of which $\mathrm{C}-$ shot, as we were greatly in need of meat. Hand $\mathrm{I}$, the two cripples-for $\mathrm{H}$ — was also down with fever-pushed on, while the others remained behind to cut up the meat, as we were both anxious to get to our new camp, where we could lie down. I was mounted on our only surviving donkey, while poor $\mathrm{H}$ - hobbled slowly by my side, and though at every few yards we came upon fresh elephant-spoor, we were far too seedy to think of following them up. Before we had travelled in this melancholy fashion more than a mile beyond where $\mathrm{C}$ - had shot the giraffe, we were suddenly invigorated by the sounds of crashing branches, and the unmistakable grunting of elephants feeding on mimosa bushes.

Here was an opportunity not to be missed even by two such poor creatures as we believed ourselves to be, and undoubtedly were, so we at once made shaky signals to our servants to bring our rifies. Unfortunately $\mathrm{H}$ ___'s man, thinking him too ill to shoot, had packed up all his cartridges and his complete battery excepting a $577^{\circ}$ rifle. So, after borrowing some of my cartridges, we adranced on our unseen quarry, $\mathrm{H}$ with his $577^{\circ}$ rifle and I with my eight-bore. 'The ele- 



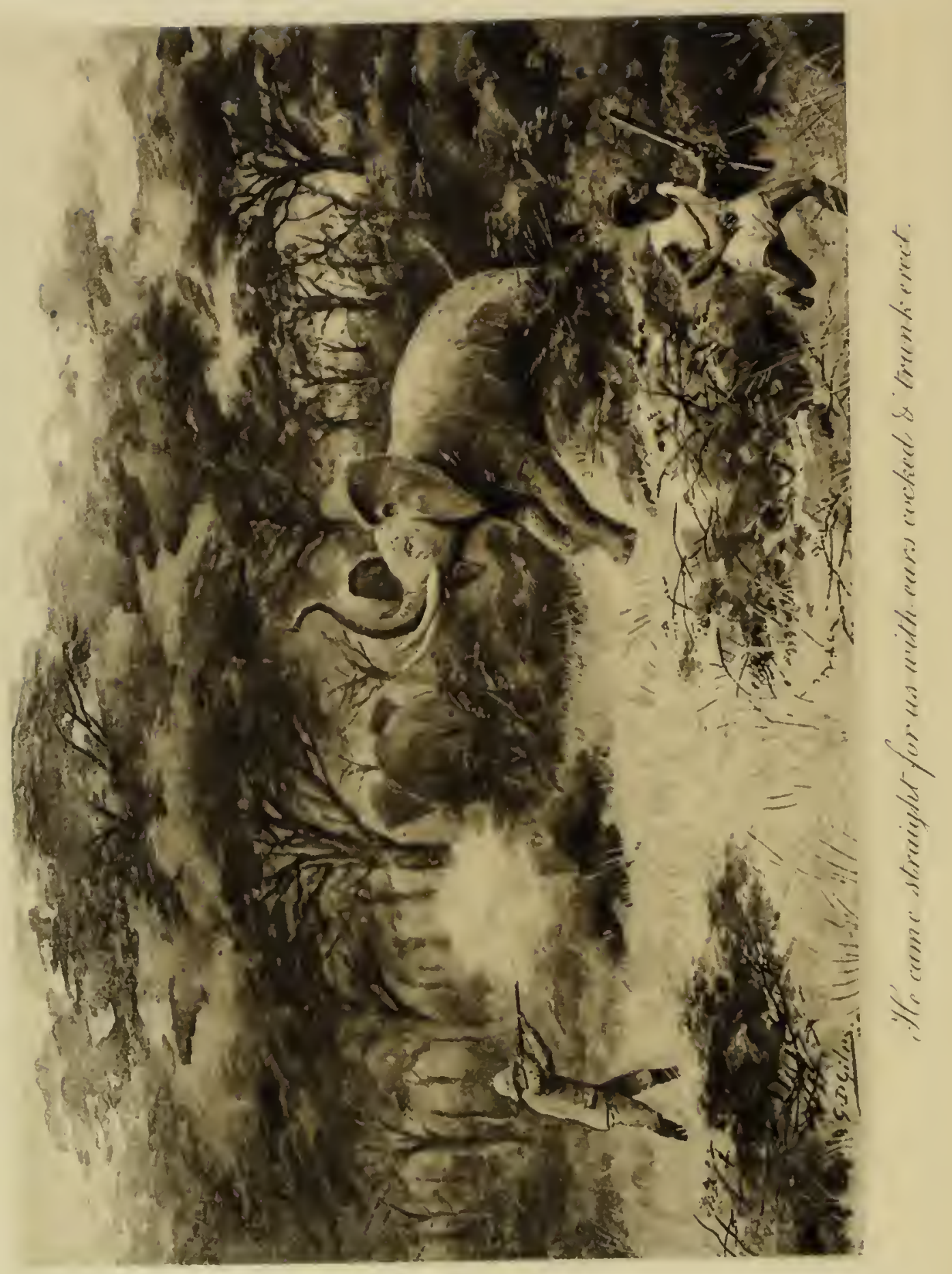


phants, when we first heard them, could not have been more than sixty yards off, and our feeble limbs had not carried us much farther than a third of that distance before a grand cow, with one uncommonly long tusk, pushed her way through the covert and offered a fair broadside-shot at her head. Aiming for the centre of the ear, I pressed the trigger, and have a dim recollection of something like a loud thunder-clap in my ear, and of being sent flying head over heels anywhere. Both barrels of the rifle, loaded with twenty drachms of powder, had exploded at the same time, an active remedy for a sportsman fever-stricken and suffering from a splitting headache. However, my first elephant was more completely bowled over than myself, for she had gone down never to rise again.

At the report of my rifle a magnificent bull with splendid tusks showed his head, and $\mathrm{H}-$ - with a shot from his $577^{\circ}$ rifle, stunned him for a second and brought him to the ground; but no sooner had he recovered himself than he came straight for us with ears cocked and trunk erect, and evidently in high dudgeon. Our gunbearers wisely fled, followed by $\mathrm{HI}$ __ , who was, of course, helpless with only one barrel of his, comparatively insufficient, weapon loaded. Luckily I had first managed to pick myself up and to reload, and when the beast was within twenty yards I put a bullet in the centre of his chest, which immediately checked his charge and made him turn back into the bush. Had I been quick enough I think I might have got in a broadside shot as he swung round, but I missed the opportunity, and 
in what seemed to me to be the twinkling of an eye he was out of sight. IVe followed him for about a quarter of a mile, but were much bothered by the attendance of a rell-grown offspring accompanied by a suckling, which snuffed about and kept up that low internal rumbling peculiar to elephants when excited or alarmed. As both declined to be driven away, and even made a threatening response to our efforts in that direction, we were obliged to shoot the larger one in self-defence.

After that, we took up the blood-track of the big bull, without further interference, until its traces ceased and the spoor was obliterated by that of numerous others who had either followed or intersected its path. 'Then, feeling utterly exhausted, we returned to examine the cow, whose measurements proved to be nine feet seven inches from toe to wither. The right tusk when removed was exactly six feet in length, while the left, which had been broken off, measured only four feet. Both were, of course, delicate, weighing respectively only twenty-seren and cighteen lbs., the former being a rather unusual weight for female elephant ivory. As we could only find the trace of one bullet, I suppose the explosion of the second barrel was not exactly coincident with that of the first, but any such mathematical refinement was a scientific waste as far as I was concerned, for the effects of a simultaneous explosion had fully operated upon me.

During the rest of the march towards our new camp, which lay east of the Kilima Mombasa hill, it was a 
pleasant surprise to note the remarkable change the rains had worked in the aspect of the country during the last three months. Then, ererything was dried up and in places the ground scorched and bare; now, the surrounding country was covered with fresh-grown grass from four to five feet in height, all the bush was bursting out in buds and leaves, and even the tops of the dry old baobab-tree were fairly well clothed with fresh verdure. It was a curious fact that the excitement attendant on our falling in with elephants made me feel fifty per cent. better, and the letting off of twenty drachms of powder drove my headache completely away instead of aggravating it, and I am quite convinced that there is nothing like excitement to help one to throw off fever. The whole secret is not to give way to, but to struggle against the almost painful lassitude that succeeds an acute attack, for the more one gives in, the worse one feels.

Before this adventure, we had quite despaired of falling in with elephants, believing that the higher forests of Kilima-njaro, which we had drawn blank, offered an only chance. Evidently the rains had brought them down, for I am positive there were none about here when we passed along towards Mandara's, three months earlier. I wish we could have stayed here some little time longer, for, had we been able to do so, I am certain we should have got several more. In fact, $\mathrm{H}-$ and Jackson, who returned here, when the rest of us had left for the coast, did get four including one good tusker, and fired at several others, 
which proves there was a fair amount of them, at the right time of year.

We offered a large reward to any one who might find the wounded bull elephant, and $\mathrm{H}-$ and I searched for him all the next day and tracked him for a long distance, but without coming across him, so, reluctantly giving up the pursuit, we moved our camp next day to Mto-Abarri. On the march $\mathrm{C}-$ shot two rhino and a hartebeest; and $\mathrm{B}-$, who went a long way round in pursuit of some Colobus monkeys which he thought he heard, obtained two fine buffalo. I went out in the evening to track some buffalo that had been seen in the morning by the rearguard of our caravan, the spoor being very easy to follow from the soft nature of the ground; at the end of a three-mile tramp I came upon them in thick bush, but moved them without getting a chance. However, I continued the hunt, and eventually killed a fine young bull with a snap-shot (the only one that I erer got with a single shot), which hit him very low at the point of the elbow, an excellent place, as their hearts lie low in the chest cavity.

'The night of our arrival here we held a great investigation, as somehow it had come to Martin's ears that the reason of the "rumpus," I have before referred to, caused by the men refusing to eat meat instead of matinde, was that an askari had gone round and told them all to refuse the meat by order of our head-man Cačeche. After a great deal of talk and prevarication this askari confessed there was $n 0$ 
truth in any such report, which he had spread about out of mere spite in the hopes of doing Caěeche harm, as the latter had procured him a flogging for stealing honey. Of course, if this were the truth the rascal deserved two dozen, but I thought Martin's mode of punishment most brutal, as he hit the unresisting culprit three times in the face, his theory being that a native thinks nothing of being thrashed on the back with a stick, but if hit in the face carries the mark for many a day as a warning to the others. Needless to say, we prohibited any such mode of punishment for the future. We found out later on that the man was, after all, innocent, and that Caěeche had been the sole originator of the row; but the askari got frightened as the investigation proceeded, and preferred to take the blame and a licking, rather than the chance of Caĕeche hereafter doing him a bad turn. I am afraid his perjury did not save him much, as he got a licking, and probably made an enemy of Caěeche all the same.

Our men, now that we were nearing Taveta, began to grumble and clamour for meat which would buy them pombé, as, after being sober for nearly two months, they were evidently looking forward to the usual holiday carouse. Having now found out that they had not originally objected to meat of their own accord, but had been incited to refuse it, either at Cačeche's or the asliari's suggestion, we withdrew our former restrictions.

We stayed here two days, in the hopes of getting more buffalo and also eland. On the first of these I 
went out on the left bank of the Abarri river below our camp, and noticed on the open plain buffalo, zebra, hartebeest, eland, rhino, ostrich, Granti, mpallah, steinbock, and wart-hog, but all so wild as to be almost unapproachable. I stalked some eland, but after a wearisome crawl only got a long shot, which I missed, and the whole morning's bag consisted of only a couple of wart-hog, one with very fine tusks. I got the first in a curious way, for I had put up a fine buffalo, out of a bush well out of range, who galloped off at once, and disturbed the midday siesta of the wart-hog, whom I spied as he sat up on his hams to have a good look round. Directly he had settled himself down again, I stalked up, from behind the tree under which he was lying, to within twenty yards and shot him through the spine as he lay. 'The other one I secured, on the way back to camp, as he was feeding with two others so greedily that they never noticed me until I got to within thirty yards of them.

'The wart-hog is a most ungainly brute, considerably larger than the ordinary wild boar, and derives his name from four wart-like excrescences situated upon his head. He is almost naked, except for a few sparse bristles on his body and a thin mane of coarse long hairs rumning from between the ears to half-way down the ridge of the back, and, in proportion to his size, has a long tail, which he defiantly erects when disturbed. He lives with his family in burrows, and roams about the plains in search of food, but, during the midday heat, may usually be found lying up under a bush or shady tree. 
The next morning I followed the right river-bank, and pursued a good herd of eland the whole day. I came up to them twice, and the first time singled out what I thought was a good bull, but, owing to their standing in the deep shade of some trees, I made a mistake and shot a very moderate one instead. The herd went off a long way, and I did not come up to them again till noon, and then only to find they had halted in an almost impossible place. However, after two hours' stalking and crawling literally inch by inch, sometimes fully exposed to their view, I got a shot within eighty yards, and eventually secured a splendid bull with thick horns about twenty-eight inches long. He took two shots, as at first he trotted off with the rest as if none the worse, but before long turned away from the herd, and after climbing half-way up a steep little hill, lay down and enabled me to give him the coup de grace.

I found the first shot had hit him fair behind the shoulder, producing a wound which would have brought down most other antelope within a hundred yards, but the eland is one of the toughest of all its tribe, and Jackson told me he had given up attempting to shoot them with anything less formidable than an eight-bore. The eland is the largest of the whole antelope group, being almost as heavy as a fair-sized English bullock, and, in the case of old bulls, the coats are thin and grey in colour.

On March the 29th we returned to Taveta, having been absent nearly seven weeks. On the way we met 
the C̆aga mail, which was two days before its time; but the Bishop had evidently been brushing them up at Mombasa, and had forbidden men heavily laden to march with the mail, and thus cause its delay. Our friends the Wa-taveta were delighted to see us again and most hearty in their welcome, for a report had reached them that we had all been massacred by the Masai. Of course, in this country there are always all sorts of "shaves," with and without reason. One to the effect that Jackson had had a row with the Masai, and lilled some of them, was probably suggested by the fact that a big Swahili caravan, returning recently from the interior to the coast, did have a bit of a brush with some Masai, killing a few and carrying off their shields and spears.

The Wa-taveta had two scares while we were staying with them this time. The first was that they were going to be attacked by the Masai, as about fifty had been seen close to the forest, so there were great preparations and cutting down of trees to block the paths, during which one unfortunate Taveta man was accidentally shot by a compatriot. The second scare, equally unwarranted, that Mandara was going to attack them, was due to the visit of some two hundred Wamoči, who apparently came on a friendly visit, though the Wa-taveta declared that they were only the advanced guard of a larger force which would have attacked them had it not been for our caravans being there at the time.

We found our garden in a healthy condition, though 
rather overgrown; the lettuces had come up well, the radishes were as big as turnips, the potatoes, onions, and a fer turnips flourishing, but the peas and beans nowhere. The day after our return Count Teleki reached Taveta, having come by the Pangani route, and taken forty days to accomplish the journey. He had left many loads behind at Mombasa and Pangani, haring been rendered short-handed by the desertion of numerous porters, and he now had to send back men to bring up these loads, which would entail at least a delay of two months.

He had already had one fight close to the coast, which resulted in his killing nine natives and losing two of his own men, while a solitary German resident, with his askari, stood by and feebly protested in the name of the German Government and the German East Africa Association. However, in spite of his difficulties and labours, both he and his companion, $\mathrm{Mr}$. Hönel, looked well and hearty, and were in excellent spirits; they had compiled a map of the country adjoining the route they had taken, but must have had some difficulty in executing it, as the man who carried the box containing all their scientific instruments had deserted, and thrown his load into the bush, so their only available instruments for the surrey were a watch and a compass. Count Teleki was full of the Masai he had met near the W'Arusha Wa-čini, and said they were not to be feared at all, but I rather think those he encountered represented a degenerate Masai tribe, or chiefly cousisted of old men and boys, 
the usual attendants on the large herds of Masai cattle.

Our time for the next few days was busily occupied in making preparations for the return of $\mathrm{C}$ - and myself to the coast, as we were obliged to leave about April the 2oth, and were anxious to make another short trip before bidding a final farewell to Taveta. There was a good deal to be done in matter of disinfecting and packing our head-skins and skulls, to insure them against the attack of a local pest in the form of a small black flying beetle.

Before learing, we experienced several earthquake shocks, one of which awakened me in the early dawn by shaking the grass walls of our hut, and to such an extent that I thought some one was trying to get in. It also rained almost incessantly, and, as a matter of course, we were ovcrrun with ants, black and white, in addition to innumerable other insects.

A man was brought in one day with a broken thigh, and wanted us to set it for him; he had been charged and knocked down by a rhino while out tending cattle, but as the accident had happened some time before, and faulty union had taken place, a refracture of the bone would have been necessary before any attempt at resetting; and this was rather beyond our surgical skill.

After remaining five days at Taveta, we determined to separate into two parties, $\mathrm{B}$ - and $\mathrm{I}$ Rhombu, and $\mathrm{C}$ - and $\mathrm{I}$ visiting the sonthern border of Lake Jipé, where the Count told us he had scen great quantities of raried game. The Count himself 
talked of making a trip to Mount Meru to pass the time until the loads, he had abandoned for want of carriers, should arrive, after which he intended to proceed, in the hope of carrying out his original programme of crossing Masai-land.

On the 5th of April, having bade good-bye to the Count and wished him all luck, C- - and I left Taveta and encamped for the night at our old quarters by the shores of the lake. I shot some florican, spurfowl, guinea-fowl, and partridges on the way, and $\mathrm{C}-$ shot a Kirkii and a mpallah. The next day we proceeded to the end of the lake and pitched our tents as near to the water's edge as the dense fringe of the thick reeds and rushes would permit, and saw plenty of hippopotami, several Walleri, and a great many prettyplumaged birds and water-fowl of all descriptions; but we only shot a few sand-grouse, partridges, and a lorely blue African kingfisher. The surrounding country was somewhat unhealthy, owing to the low-lying ground and the bad water, which was of a pea-green colour, and smelt most disagreeably notwithstanding plenty of boiling and filtering; the latter process did not succeed in changing the colour nor in removing all the fungus growth, and finally the apparatus got choked with slime and struck work altogether.

The afternoon of our arrival we went for a stroll in different directions to have a look at the ground, Cselecting the bush that runs down almost to the shores of the lake, while I explored the open plains, in most places perfectly flat and level, and therefore most 
unsuitable stalking-ground. 'The game, though plentiful, was very wild and at times almost unapproachable. The zebra, hartebeest, and Granti were in great abundance and very much in the way, as when disturbed they mored everything else with them, and, not infrequently, while we were lying down waiting for a farourable opportunity to stalk an oryx or a rhimo, would walk up to within thirty yards of our ambush. The oryx, specimens of which I was most anxious to procure, were not only the wildest of all the antelopes, but also the most cumining, and if once disturbed would gallop off and hide behind a bush and peer round the side to see if anything was coming; then, if one continued the stalk, they would start off at a great pace, and not put their heads down to feed for at least a couple of hours. 


\section{CHAPTER XIX.}

The Gaselle Wulleri-Hippopotami-Construction of a raft-Hipposhooting-Alligators-Return to Taveta-Journey to the coastAscent of Mount Ndara-Vulturine guinea-fowl-German colonisation-Farewell.

Notwithstandivg the shyness of the game, we had capital sport here, and killed between us in ten days one mpallah, five Kirkii, three hartebeest, six oryx, eight Granti, two eland, three steinbock, four hippopotami, one silver-backed jackal, and one Walleri, a prize I was fortunate enough to secure near the edge of the bush. We had seen, at different times, specimens of this antelope, but all were too wild to let us approach within rifle-range.

The Gazella Walleri is about the size of a mpallah, but rather longer in the leg, and distinguished by a length of neck which gives it somewhat the appearance of a young giraffe. The hairy coat is remarkable by three distinct and well-defined surface-markings, the dorsal and upper lateral chocolate colouration being. abruptly divided, from the almost white underneath part, by a wide fawn tint. The annulated horns are lyre-shaped and about fifteen inches long, with a graceful backward curve and peculiar inward bend at the tips. Granti were in extraordinary profusion, though extremely wild, and among the herds we noticed many fine bucks. 
It may be worthy of record that they would often allow us to crawl towards them, without showing any sign of alarm, until we were within a fair rifle-range, whereas if we attempted to walk towards them, even in a stooping position, they would invariably start off before we had approached within four hundred yards.

Besides the game killed, we saw lions, rhinoceros, lesser kudu, wild dogs, hyænas, cheetah, water-buck, and zebra, the total seen amounting to nineteen varieties. I was responsible for losing the only chance at a cheetah; he got up while I was crawling in to some oryx, which I had been pursuing all day, and during a momentary reflection about sacrificing the prospect of getting the oryx he got out of range, but not before I had noticed that he was about the size of a small leopard, though longer in the leg, and of a light yellow colour marked with black spots.

I had only one good day with the oryx, in which I came upon a big herd of over a hundred, and after a rery long and painful crawl approached them within two hundred and fifty yards, at which distance I secured a couple. While we were cutting up the meat a strayed member was seen approaching as though desirous to rejoin the herd to which he belonged. But no sooner had he satisfied himself that we were not the objects of his search, than he started off at a splendid pace, and was quite three hundred yards away before I could get hold of my rifle. I made, howerer, a lucky shot right through the heart, and he fell doad in his trackis. 
A few Masai passed our camp one day and paid it a visit while we were out shooting. They had come by Lanjora, and were driving home their share of cattle looted from Ndara. They of course asked Cačeche for hongo, a request he considered with diplomatic courtesy, but refused on the sole ground that "there were not enough of them."

We came across an old Masai encampment, in the bush, quite seven miles away from water. The huts were curious round mud balls some three feet from the ground, interwoven with the bushes and entered by a hole on the south side; in these, I was told, two or three Masai would sleep, and that they came down here in the dry season to graze their cattle. They scarcely ever drink water, but subsist on milk and the blood of the cattle they kill, and are in the habit of watering their herds only once every third day.

The climate in this district was relaxing and the heat most enervating, and as it was very laborious work walking after the game, our donkey proved a great help. I was now in rather a bad way, as all my boots were worn out, except one pair which fitted badly and blistered my heels.

While we were busily employed shooting, we sent relays of men back to 'Tareta with meat, and told them to return loaded with palm-branches (mwale?), as I was very anxious to make a raft which would enable me to get at the hippos on the lake. The men and even $\mathrm{C}$ __ tried to dissuade me, declaring it was useless, as even if we succeeded in shooting some, we should not be able to 
drag them to shore on account of the shallows which formed the edge of the lake. I was nerertheless determined to have a good try, on the "nothing venture, nothing hare" principle, as at the worst I could but fail. Accordingly, as soon as the men returned with ten loads of long palm-branches, I set to work with them to construct the raft. This was effected by placing alternate layers crosswise for the foundation, until the bottom, some twenty feet long by five wide, was thick enough to support three or four men; this being accomplished, we made a sort of bulwark all round the sides and ends, to act as a screen between us and the hippos. The want of ropes proved rather a difficulty, until we found an excellent substitute in thin strips of raw hide, with which we bound the palm-branches firmly together.

On April r th we were leaving the camp for Taveta, so early in the morning our raft was launched, and boarded by myself and two gun-bearers who shared my keen desire to secure a hippo. Although the raft floated capitally, our progress was naturally slow as her ends were square, but the two men were able to punt her along, keeping about two hundred yards from the shore, the water being nowhere deeper than from seven to eight feet. IVe passed hundreds of large alligators, floating on the surface of the lake, and just showing a portion of their long heads above the water, but as we approached them they sank out of sight without making the slightest splash.

Before long we viewed a small school of hippos, so 



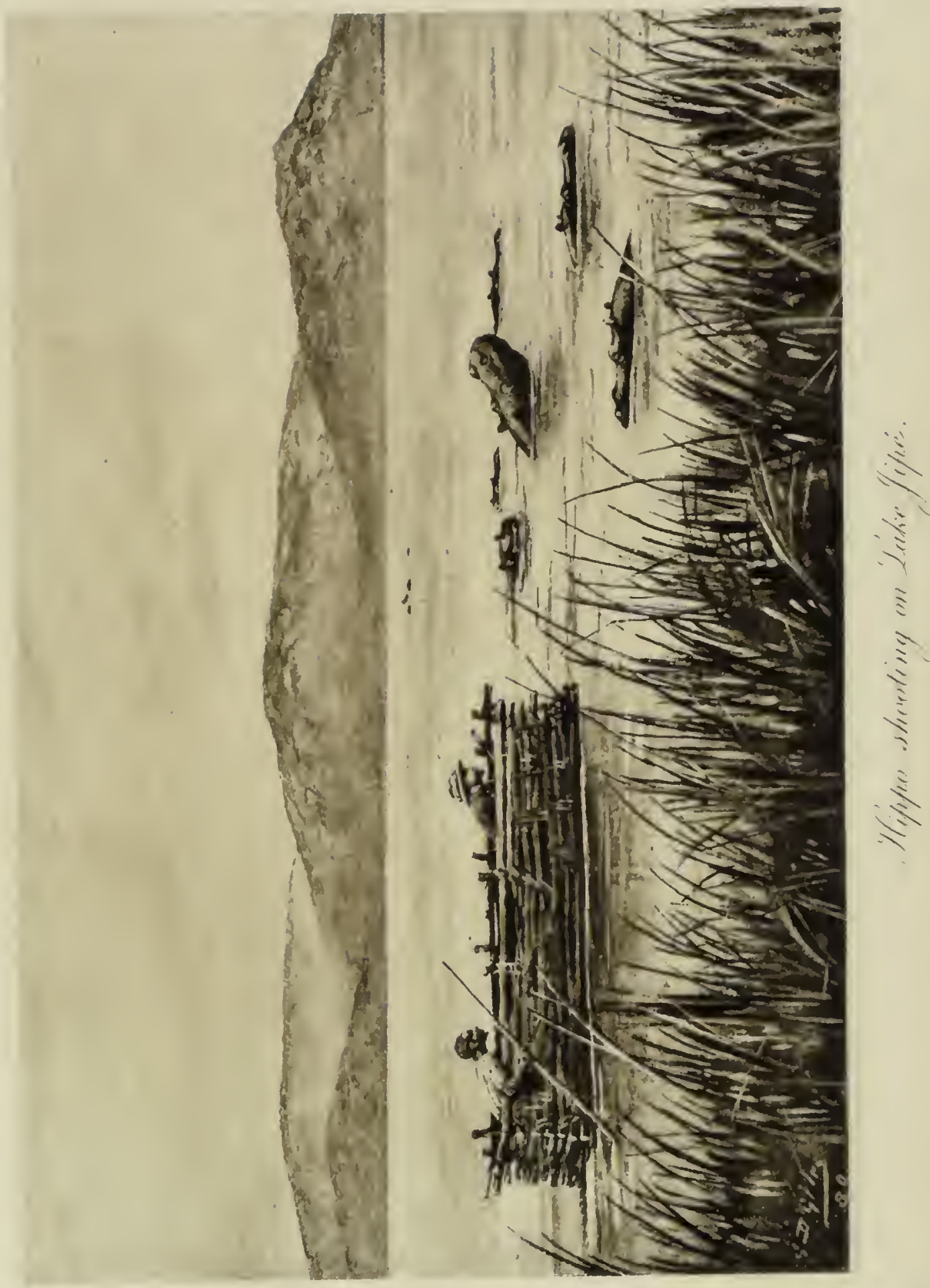


we all crouched down, while the men punted me cautiously torrards them. They did not seem to mind our approach in the least degree, but continued to enjoy themselves by puffing and snorting and blowing water, in jets, from their nostrils, and now and again sinking down, to reappear at the end of two or three minutes, and, with their heads half out of the water, to take a look round. Then we were within thirty yards, they ceased their gambols to gaze with astonishment at what I suppose was a first attempt to navigate these waters. Drawing a bead, on the eye of a big fellow quite near me, I fired. The effect was a terrific plunge and an immediate absence of anything like a hippopotamus' head to be seen anywhere. After about fifteen minutes patient waiting, heads began to pop up all round me, but another shot was followed by another plunge and another complete disappearance. This time I had only to wait a few minutes before the heads reappeared, for I fired my second shot before they had time to take in enough air for a long dive. After my third shot I think their first impulse of curiosity gave way to a sense of danger, as, before reappearing, they placed a long distance between themselves and the raft, and were making hard for the middle of the lake. I now decided to give up the hunt and employ my time in fishing, while hopefully awaiting the appearance on the surface of some hippo carcasses. The fish, however, were not hungry, or, if they were, my bait was not sufficiently attractive; but I continued to practise the 
"gentle art" until the smooth surface of the water was broken by a small round disc, the first appearance of a dead hippo.

Tre towed this carcass at the end of the raft as far as we could towards the shore, and left half of it, high and dry on the shallows, about a hundred yards from the edge of the lake, intending to send back men, later on, to cut it up. The next morning $\mathrm{C}-$ embarked on the raft and killed two hippos, while I took a stroll back to the carcass of my prize, which I found surrounded by swarms of alligators. I lay up for some time in the reeds, hoping to get a shot at onc, but they were too cumning to exhibit any portion of their body more vital than the tips of their snouts, through which they drew in breath with a curious hissing noise.

In the afternoon I went out and shot another hippo, who, instead of sinking after receiving the bullet, went through the most extraordinary gyrations, chiefly consisting of a series of somersaults, which, while exposing the whole of his giant proportions, were so rapid that it was some little time before I could give him his quietus. I suppose my first bullet had torn up the brain tissue without causing a sufficient amount of blood extravasation to produce death.

After this, we gave up the pursuit of hippos, as there were no very large ones on the lake. 'The two bulls and two cows we killed, though the largest we saw, had only small tusks, and I believe the lake hippos are always inferior in size to those found in rivers. 
The success of my raft was triumphantly established, and without it we should not hare obtained a single specimen, as, although it was evident, from their innumerable tracks, that the hippos were in the habit of coming out at night to feed in the bush, there was no moon while we were here, and on several occasions, when we lay out to intercept them at early dawn, we found they always retumed to the lake before daylight. Once, when I had gone out about 2.30 A.M., after a very dreary wait through the night, the silence only being broken by the occasional growl of a lion and the mournful moan of hyænas, I saw, about a mile off, a "big black mass approaching the lake from the bush. "Hippo at last," said I to myself, and ran as hard as I could to intercept the beast, but only to find, on nearer approach, that it was a large rhino cow followed by a calf.

The insects were an ererlasting pest at this campmosquitoes, midges, beetles, spiders, and ants of all sorts, until it really seemed that every hour produced a fresh species. One ant in particular was quite terrible, the sĩafu, which is of a dark red colour, and has a broad flat head terminating in a crescent-shaped forceps which it buries in the flesh of the unfortunate rictim, and there literally stands upon its head. We were frequently roused in the middle of the night by sudden attacks, in force, of these pests, and the only way of getting rid of them was to burn the ground for some distance all round.

While in pursuit of the hippos, $\mathrm{C}$ - told me that 
one beast passed under the raft, grating and bumping against it with its back. Previously I had felt a similar sensation, only in my case it was due to a large alligator, whose scaly back caused the raft to vibrate so strongly that I thought, for the moment, we had run aground. After landing at our camp from my second royage in quest of hippos, we sent off some men on the raft to cut up the beast that $\mathrm{C}$ - had lilled some two miles farther down the lake, but they shortly returned, with rather a sheepish air, and said that they did not dare go on, as it was getting too dark, and the hippos were very fierce and had come up quite close to them!

The following day we were to return to Taveta, and in the early morning a special detachment of our men arrived to help carry in the meat, and were accompanied by several Wa-taveta, particular friends of Martin. He had given them the "office" that there was a chance of obtaining meat for nothing if they cared to undertake a sixteen-mile walk. I had, by the bye, about this time a row with our head-man Cačeche, for on my asking him how many loads of meat had been carried into camp from the first two hippos killed, he had the impudence to say that only two loads had been brought in, and this, after my orn eyes had seen quite thirty of our men return laden with meat. Me excused himself by saying that, as it was dark when they came in, he had not been able to take proper count of the exact number; but the fact was that, as usual when within a march or two of 
THE PORTERS DETECTED IN STEALING MEAT. 253

Taveta, every one of the porter's tried to steal as much meat as he could carry in addition to his load. Every pound of meat at Taveta meant so much money, and money meant unlimited pombé and the indulgence of all vices; consequently, if not properly backed up by one's head-men, it was rel'y difficult to get any meat carried back for our own use.

I therefore, before maling a start, inspected each load, for of course Cačeche informed me that there were not enough men to carry twelve loads of meat, and wanted to leave it behind-an assertion which, on the face of it, was too ridiculous, considering that we had altogether seventy men with us to carry eleven loads of heads and head-skins, and about thirty loads of personal luggage and camp equipment. 'These last, I found had been converted into fifty light loads, their proper weight of sixty to seventy lbs. being made up with the meat that they had snealied; so I at once deprived each man of a portion of his ill-gotten gains, and then rearranging the loads, succeeded in getting all the general store of meat carried back to Taveta. The men who had joined us in the early morning said that they had seen three elephants near the north end of the lake, but we saw no signs of them on our way home, and during the whole return journey only succeeded in bagging one solitary snipe.

On our arriving at Taveta after a four and a half hours' march, we found that $\mathrm{B}-$ and $\mathrm{H}-$ had returned from Rhombu the day before, after having: excellent sport. Their bag amounted to forty-one 
head, including two oryx-beisa, one lioness, four wildebeest, sereral very good Granti, one ostrich, one reedbuck, one serval or tiger-cat, \&c. Jackson had also come back from a risit to Mandara, but Count Teleki had left to visit Miriale, a small chief living between the Wa-moči and IVa-rhombu. ITis intention was, I believe, to ascend the mountain from that place, and we afterwards heard that he made a gallant attempt, but failed to gain the summit.

Our trip had now practically come to an end, and all that remained to be done was to dress our head-skins and pack them up as well as possible for the journey down to the coast. While $\mathrm{C}$ - and I were thus busily employed, B__ and $\mathrm{H}$ __ who intended staying in those parts a few months longer, set out for the jungle surrounding Kahé, with the determination to work seriously for elephants; but the day after their departure special messengers from Mr. Holmwood arrived at Taveta, bearing the sad tidings of a sudden bereavement in B-'s family, which naturally cast a gloom orer us all. In consequence of this grierous news $\mathrm{C}$ - and I delayed our departure for a day, in order that $\mathrm{B}$ - might rejoin us in time to march back with us to the coast. On this account it was not till April 2 Ist that we bade a regretful farewell to the hospitable Wa-tareta and to our headquarter's camp, where we had spent such a pleasant time. More simple-minded or kindlier natives than the Wa-taveta I never expect to meet, and they have my best wishes for remaining as happy as we found them, undisturbed either by the 



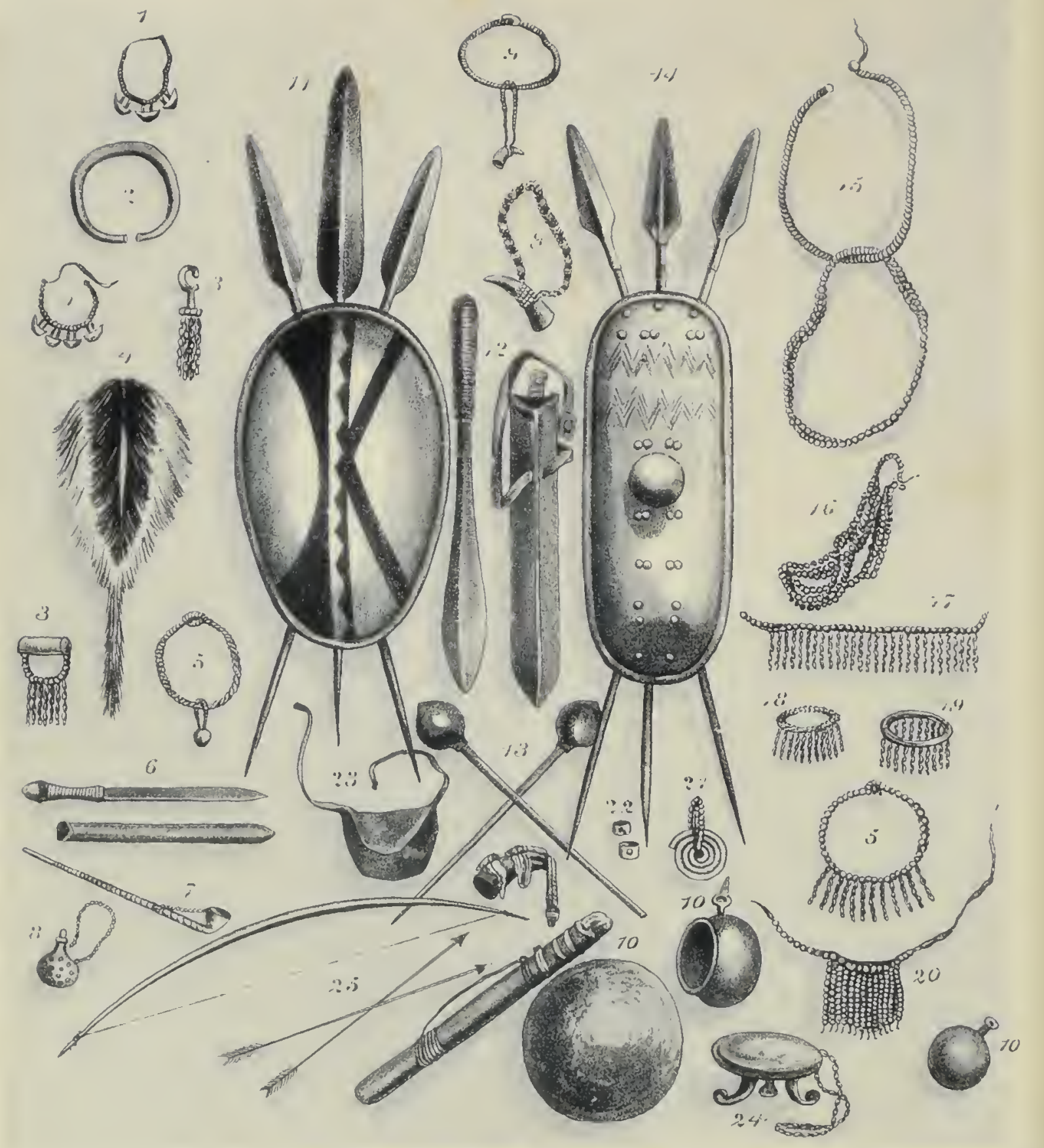

1-Niglt ratties worn on ankle to shew the wearer is not a thief.-2-Brass wassive necklace taken from a man whose head was cut off, 3 Native earrings. 4-Colobus monkey skin, with slit in the middle, worn by the Masai round the neck. 5-Necklaces of coiled brass wire; fine chains and beads attached. 6-Caga knife and sheath. 7-Caga Pipe, 8-Gourd snuff-box studded with nails 9-Taveta snuff-boxes(horn), decorated with beads and fine chains. 10-Wooden bowls from Tavetá I -Kil,oso or Masai shields and spears 12-Native sword and scabbard. 13-Knobkerries. I4Wa Rnombu shield and spears. 15-Taveta married woman's bead and leather girdle. r6-Sweet. smelling grass necklace.-I7-Bead and chain necklace, I8-Ditto bracelet. 19-Brass wire coiled bracelet with chains. 20-Complete dress of Wa Moci damsal (red bead tassle). 21-Taveta married woman's brass coil earring. 22-Native rings. 23-Kiboso leather flap to sit on, worn bchind. 24-Wa Teita 3 legged stool-chain attached. 25-Wa Teita bow, poisoned arrows and quiver 
RUMOURS OF THE VICINITY OF BRIGANDS. 255

inroads of civilisation or the hostile assaults of their neighbours.

Of the journey back I need not say much, as it was all over the same ground that we passed on our march up. Being downhill, most of the way, it was easier and pleasanter going, and on account of the time of year water was more plentiful. The only long journey we had to undergo was from Maungu to Ziwani, where on this occasion we found sufficient water. Game was also more abundant on the line of march, and between Taveta and Maūngu we saw quantities of mpallah, ostrich, Granti, hartebeest, zebra, oryx-beisa, steinbok, eland, giraffe, besides a few wart-hog and one or two lesser kudu. We were certainly inconvenienced by heavy rain most of the time, which made progression tiring, as, owing to the light and friable nature of the soil, the path became most slippery. However, I should not complain, for these rains enabled us to break the long march of forty-five miles from little Langora to Mu-komeni, as we found, half-way at Ziwa-mazungu, a dirty puddle of sufficient water to allow us to encamp for the night.

On nearing Matate we had to be on the qui vive, for we received the intelligence at $\mathrm{Mu}$-komeni that Mabrouki, a rebellious subject of the Sultan of Zanzibar, was hereabouts, living by brigandage and lying in wait to loot passing caravans, and that he had recently attacked and killed a few of the hundred men that Count Teleki had sent back to the coast, to fetch up the surplus loads he had been obliged to leave behind. We 
here came across a few men loitering about the route, who, I believe, were some of his scouts; but we passed through unmolested, and I afterwards heard that he only attacked Srahili caravans, being deterred from annoying those belonging to Europeans from fear of incurring the displeasure of the English Consul.

We arrived at Mkuyu (the place of the sycamoretree), at the foot of Ndara, on April 25th, and after resting an hour or two here, the cararan marched on to Jovia, while I mustered up enough energy to climb the mountain and examine its inhabited plateau. I must say that I was strengthened in my determination by the idea that this route, apart from being new to me, would be somewhat shorter than the tedious march of eight miles round the foot of this range. I never made a greater mistake, for, to begin with, there was a stiff climb of about $x$ joo fect by a rocky and difficult path to be negotiated, and then, after crossing the undulating slopes at the summit, came the track leading down to Jovia, which proved to be the very worst road that ever I met with in the whole of my randerings in Africa; slippery rock and loose boulders every yard, the latter for the most part hidden by long grass, and the whole intersected here and there by mountain watercourses. Howerer, I was fully rewarded for my pains by the magnificence of the view of the surrounding country to be obtained from the summit of the mountain. The flowers, too, by the wayside were many and various, and some sweet-scented, but I came across 
none of the orchids that I expected to find after reading Messrs. 'Thomson and Jolmston's accounts. Perhaps they were not then in flower, and my scant knowledge of botany did not allow me to distinguish them from the other herbage.

On reaching the highest point I rested for a time to take breath at Mr. Wray's residence, which unfortunatcly was shut up, and, as I learnt from some natives, he had just started to visit us at Jovia. Mr. Wray lives in a small two-roomed house of galranised iron, consisting of a store-room, and a bed and sitting room in one. I looked in at the window of the latter in the hopes of discovering an Englishspeaking servant, but the only living things I saw were a cat and littcr of kittens occupying Mr. Wray's bed. The house stands in a fine position on the brink of a precipice about I 500 feet in depth, and is surrounded by a few outhouses and huts tenanted by his native Wateita servants. A long and low hut was in process of erection, intended, as I was afterwards informed, for a church and schoolhouse. The inhabited plateau is picturesque and nicely undulating, extending for several miles mostly under cultivation, and the air is very clear and bracing.

On reaching the camp at Jovia I found the caravan had arrived, and the tents pitched and everything ship-shape, thus proving that I lad taken the longer route. We had here an enforced delay of one day, as we had expected a contingent of 
Rabai mission-men to mect us and assist in carrying some of the loads, and thus enable Martin, with as many men as we could spare, to return to $\mathrm{I}-$ at 'Tareta, who in the meantine was necessarily very short-handed. Unfortunately we did not meet them till forty miles farther on, as, through some mistake, they had not started from Rabai in time.

We therefore thought it best to remain here a day to give the Rabai men a chance of arriving, and in the meantime tried to induce some Wa-teita to assist us in carrying our baggage. During the course of the day twelve promised to accompany us to the coast, but by the following morning they had had time to think better of it, and not one would come. Is we could delay no longer, we made the best of the situation by increasing the weight of our loads, and thus enabling Martin to return with twenty-eight men. I would here say that we were deeply indebted to him for his excellent services, and can thoroughly recommend him to any one contemplating an expedition in this country. Indeed, I consider any traveller who does obtain his services exceptionally fortunate, and in the best possible position for conducting a successful and pleasurable trip.

From Jovia to Mombasa the journey was without incident, the only thing to be noted being that we obtained several of the vulturine guinea-fowl, a species we had never before come across. 'Their plumage is lovely, and but for the disfigurement of their ugly, bald, 
and rulture-like heads, they would be most beautiful birds. We eventually arrived at Mombasa on May 3rd, the few days spent here, while waiting for the homeward bound mail, being fully occupied in repacking our heads and skins for the royage home, and in paying off our personal gun-bearers and those of the men that were not to return to $\mathrm{H}$ - . I proposed to purchase the freedom of my favourite gun-bearer, Fāas; but he told me he would prefer to remain a slave, as he then would always have a home to go to when out of employment; I therefore saved the eight pounds that his emancipation would have cost.

The German colonists at this time were coming out in shoals by every monthly mail, and on the way back I made the acquaintance of one of the heads of their Association, who, like us, was returning home. In the course of conversation I gathered that the German notion of colonisation in these parts was somewhat arbitrary, and I rentured to prophesy to him that unless they modified their intentions as to treatment of the natives, they would either drive the latter out of the country or become involved in serious disturbances. Subsequent events, owing to the tactless and overbearing policy of some of these adventurers, have, I fear, practically fulfilled my forecast, and consequently half-ruined a great number of the 7000 British subjects (chiefly IHindus and Parsees) who live in Zanzibar and on the coast of the mainland. 
Regretting the many shortcomings of this work, I now take leave of my readers, and can only hope that they may not be quite as glad to hare reached the end of the narrative, as their humble servant, the author, is at the present moment. 


\section{LIST OF GAME}

\section{SHOT BY THE PARTY ROUND KILIMA-NJARO BETWEEN \\ DECEMBER I886 AND APRIL I 887.}

Buffalo . $2 \mathrm{I}$

Rhinoceros

Elephant

Lion

Hippopotamus

Giraffe .

Leopard .

Zebra

Eland

Wildebeest

Hartebeest

Oryx-beisa

Granti .

Mpallah.

Water-buck

Lesser Kudu

Bush-buck

Reed-buck

Red Bush-buck .

Valleri .

Duiker

Steinbock

Neotragus Kirlii

Grave Islanc Gazelle

Ostrich .

Warthog

Serval (Tiger-cat)

Hyæna (spotted)

Hyæena (striped)

Jackal .

Fox

Great Bustard

Alligator

Graud Total

66

2

$+$

4

6

9

39

9

40

39

I7

2

4

2

I

I

5

I 5

I

6

3

I

6

2 


\section{LETTER FROMI SIR R. G. HARVEY,}

Including an Account of a Trip up the Tana River.

Mr deAR JoHnny,-According to your wishes, I send you a short account of our last expedition to East Africa, which altogether lasted ten months. We started from Mombasa early in Feburary with 290 Africans, six Goanese, and one Indian servant, in charge of Martin, who, with Greenfield, Hunter, and myself, male up the caravan. We had with us I 30 Sniders, twenty tower muskets, two Martini-Henrys, and ten Colts repeating-rifles, and with our gun-bearers and selves were just i So men under arms.

We took up our old quarters at Taveta, and went over most of the old ground of the year before, with the exception of the country near Lake Jipé. We also went considerably farther west towards Mount Meru, and north-east up to the Ukambani hills. In the Meru direction we soon got among the Masai, and notwithstanding that two large parties of warriors were absent fighting in Ukambani and near Pangani, they gave us so much trouble that, after a few days, we were glad to leave then. We were much struck with the enormous amount of cattle in their country and the tameness of the wild animals, which allowed us generally to approach within two hundred yards, often indeed much nearer, without being disturbed. The quantity of Masai liraals and the number of cattle grazing made rifle-shooting positively dangerous, as the wounding of one of their animals would probably at once have formed a casus belli. Here we found large quantities of $G$. Thomsoni, much resembling the common chikara of India, but much more brightly coloured, and with a dark stripe along their flanks. Their horns are also longer and straighter, and do not diverge so much.

In the Ukambani direction we found immense masses of game, especially oryx and wildebeest, and considerable numbers of 
eland, butfalo, rhinoeeros, and Thomsoni. On one march we passed no less than twenty-three rhinoceros in ones, twos, and threes.

Hunter secured a rhinoceros cow with a horn thirty-two inches long, and I a bull with a horn twenty-nine inches long and twenty-seven inches in eircmmference at the base. This is by far the henviest horn I ever saw in Africa.

During our stay in the Kilima-njaro region we had very good sport, but game was not plentifnl near Taveta, like the year before. A Dr. Abbott, an American, and several Germans had also been shooting, and that, with our former expedition, had driven the game back into the Masai eountry; in fact, any future sportsman who visits these regions, if desirous to get really first-rate sport, will have to go right in among the Masai, and have to go to the expense of a very large caravan. Among other game we bagged four lions-Hnnter one, and myself the other three. I was very unlueky in losing three others that I wounded, bnt a very narrow escape I had from a wounded lioness made me very ehary of following up womnded lions into thick bush by myself on foot. Hunter and I also succeeded in shooting the small animal up the mountain that we were so anxious to shoot the year before. It turned out simply to be the ordinary duiker of the plains below, which had at I I,000 feet developed a long coat, and in the distance much resembled the musk-deer of the Himalayas. Dr. Abbott secured an extraordinary animal at about 9000 feet very like a serow, but which was even darker in colour and on shorter legs, with horns about nine inches long. This I believe to be an entirely new species.

We were unlucky this year as regarls accidents, losing one inan lilled by a lion, two by buffalo, three speared by Masai, and two from dysentery; the latter was very prevalent with the men, and we onrselves and Indian servants all suffered from fever. The three men who were killed by the Masai included our head-man, Ali Mahomed, whose loss we much regrettcd. Our men, thirty-two in number, who were carrying hor'ns, \&c., to the eonst, were attacked while erossing a dry watercourse just 
beyond our old camp at Maji-a-chumvi, and the last thrce men were nearly instantaneously killed. All the party were armed, and Ali Mahomed was earrying a Colts repeating-rifle with fifteen cartridges in it. We returned to Mombasa on September ist, after a very dry mareh, there being no water at Maūngu, and little at other places. During this trip we shot some 350 head of big gane, which werc all eonsumed by our men.

Here the men expected to receive all the pay that was owing to them; but knowing what the result would be, we refused to pay over their wages, but eonsented to advanee eaeh porter ten rupees, and some of the steadier men more. The result, however, was not eneouraging, as next morning, when we wanted some men to work, only six turned up, and these were not entirely sober. The rest of the earavan had a regular African debauch, and retumed gradually as their ten rupees disappeared. Africans have only three ideas of pleasure, eating, drinking, and women. In this ease most of the money went to a small Goanese shop which sold Hamburgh brandy. This fearful coneoetion is imported into East Africa by Messrs. Hansing \& Co., of Zanzibar, and is sold at four and a half dollars per dozen.

It was not until September I I th that we were ready to start again on our trip to the Tana river. I send you a short account of this expedition, beeause, with the exeeption of the brothers Denhardt, no European had ever ascended this river farther than thirty or forty miles.

The Tana river rises around Mount Kenia, and after a southeasterly course flows into the sea about two degrees S. latitude. We found canoes could probably aseend for some three hundred uniles during the rainy season.

We reached Freretown at twelve o'elock, where we expected to find the earavan assembled, but it was 1.30 before a sufficient number of our men had arrived to make a start, and even then a large number of drunkards were left behind. We then marehed on through thiek plantations of coeoa-nuts, \&e., until the evening of the I 3 th, when we erossed the Kalefi Creek, where wc saw the surveying-boat, the Stork, about which the 
natives were most excitcd, under the impression that it was a German man-of-war which had come to annex that part of the coast. Here Greenfield and Hunter, hearing that a dhow was going to start for Malindi, agreed to go in her in order to avoid the stifling heat of the coast. The heat was bad enough, but from former experience, I thought the dhow would be worse, and so remained with the caravan. On the i6th, after three very hot marches, sometimes through plantations and sometimes through bush in which I saw a few old elephant tracks, we arrived at Malindi, and found my fricnds installed in a house belonging to the Lewali of Mombasa. His nephew acted as our host and did his best to please us. He was a finelooking man, well dressed, good-mannered, and as fair as any European.

Here we had considerable difficulty in getting guides to accompany us, and as they did not, or said they did not, know the dircct route to Golbanti, we had to make for the mouth of the Tana, and then trust to following it up.

Our first march from Malindi only took us to Membrui, as we only had one small dug-out canoe to cross the Sabaki river, which was a slow business for ncarly two hundred men and a large quantity of baggage.

After Mcmbrui we marched through a sandy flat country that reminded me much of Aldershot, being covered with dark plants and trees which much resembled fir-trees and heaths at a distance. This country is intersected with salt-pans, which are formed by the highest tides depositing water in the hollows; this in a short time drics up from the heat of the tropical sun and leaves a thin layer of salt. Wild animals are very fond of this salt, and we here saw the first animal we had met with since Mombasa. We reached Merereni in the evening, and found ourselves on the shore amonig a lot of dilapidated huts. These huts are used by pickers of mereri (olchilla weed), which grows in considerable quantities in the neighbourhood, and is used as a dye.

As my friends did not like the heat, which certainly was 
very trying on the white sands, we settled to start at six o'eloek the following evening. This we did, and arrived at a creek which we had to eross at 7.30. We had, however, to wait nearly two hours until the tide was low enough, and even then had to wade with the water up to our waists, and after that to hurry along as hard as we eould go to reaeh the next creek before the tide had run up. This we did after an hour's hard tramp, and had again to strip up to the waist in order to eross. Our seven dogs, which were swimming, found that it was as much as they could do to swim these long stretches with a heavy tide. We finally encamped at I 2.30 among some uninviting sand-heaps.

Next day we continued our mareh along the sands, the dogs pursuing, and snapping at the erabs which crawled into the sea in hundreds on our approneh. One of our dogs, Kiboko (the hippopotanus) by name, who was always the elown of the pack, was caught by the nose by a large crab, with which he tore over the sands howling loudly, until one of our porters with some difficulty removed it.

On our arrival on September 2oth at the mouth of the Tana, Martin and I got the drag-net out, but were only successful in eatching a few small fish and some excellent prawns. TVe then, with our servants, got into a large dug-out canoe, and sailed up the river through some fine tropical regetation to a place where the Sultan had a small guard of irregular Arab soldiers. Here we were joined by the rest of the caravan. Early next morning I was awakened by the news that Mr. During, a missionary, a native of Sierra Leone, had arrived. He had kindly eonsented to do his best to buy me some dugout canoes, a small fleet of which I knew would be required to carry our stores and the men's food up the river. He had kindly brought down a small dhow whieh belonged to the mission, a sail in which was very pleasant after the tramp of the last week. We started at eight o'clock, the servants accompanying us, but the caravan had to go overland and get along as best they could through the thiek bush and mangrove swamps - a most unpleasant tramp. 
We ourselves arrived at Charra about 4.30, the only objeets of interest we had seen being four or five hippopotami and two flights of whistling teal. Here we at onee began to piteh eamp and prepare for the mosquitos, as in a former trip here in ${ } S_{5}$ I had found them very bad. Indeed in no part of the world have I ever seen them worse. The enormous quantity of them is doubtless owing to the swampy nature of this part of the eountry, which is here most uninviting in every way. Twiee a year for some months the whole eountry is aetually under water, owing to the river overflowing its banks.

We sat down to dinner at dusk, but the mosquitos soon appeared in vast numbers, and I was obliged to take refuge on my bed inside the mosquito-eurtains, lifting up the eurtain very gingerly to admit of the plates for the different eourses, whieh were handed me by my servant Sadalla, who was skipping gaily about, his movements eonsiderably hastened by the mosquitos.

The start the following morning at 7.30 was most umpropitious, at all erents as regards the large eanoe in whieh I was travelling, owing to my men's ignoranee of paddling; but after one and a half hour's hard work we eame to a small Wakopomo village, where we seeured the serviees of two regular boatmen.

The following is the method of propelling boats on the Tana praetised by the Wa-kopomo. One man sits in the stern with a paddle, with whieh he works the boat and steers, always keeping near the shore and shightly inclining towards the bank, so as to permit the other man, who stands in the bows, to punt, plaeing his pole on the bank and not in the water. The reason of this is that the lower part of the Tana is generally tou deep for ordinary punting.

We arrived at Golbanti about eight o'eloek, and took up our quarters in the new mission-house, which lad been ereeted sinee my former visit in eonsequenee of the murder of the late Mr. and Mrs. Houghton by the Masai. It refleets great eredit on the arehiteet and builder, Mr. During. The windows are 
all fitted with iron bars, and the upper storey has verandahs from whieh a hot fire might be kept up in ease of attaek; there is also a strong stoekade round the house and gardens, made of trunks of small trees.

On our journey up the river one of our boats with some ten or twelve men on board was attaeked by a swarm of bees; the men were soon overboard, but having to land in thiek bush, one man was lost for several days, but eventually turned up.

We stayed here six days repaeking our things and making preparations for a two months' shoot up the river.

Dnring this enforeed delay one of the party went out shooting every day to provide the eamp with meat, whieh was greedily looked forward to by our men and the few Gallas living round the mission. The only game in any number were topé (Alcephalus Sencyalcnsis). They, however, were always seeured, Hunter killing as many as four one morning.

We had great diffieulty in seeuring any Gallas as guides for onr further explorations, but ultimately, at a most extortionate figure, seeured the serviees of three.

It may be as well to mention here something about the four different raees living in this distriet. They consist of the Gallas, the Wa-sania,* also known as Wa-boni and Wa-tai, the Wa-kopomo, and the Somalis.

The Gallas are not numerous; in faet, I mueh doubt whether in this part of Africa they now exeeed three thousand in number. They originally, in all probability, formed part of the northern Gallas, but were driven south by the ever-eneroaehing Somalis, who now intervene between them and their eompatriots. At the time of my visit in 1885 they had large herds of eattle, whieh, however, sinee then have heen entirely swept away by the Somalis from the north, and by the Masai from the west. They are a tall and slender raee, with good features hut evil expression, and are very dark in eolour. Their arms eonsist of two spears, one large and the other small, both with leaf-

* Wa-sania, Wa-boni, and Wa-tai are names for denoting the same tribe, used respectively by the Gallas, Swahilis, and Wa-kopomo. 
shaped blades, the larger for thrusting and the smaller for throwing; a small native-made knife in sheath, a small eireular shield made of giraffe, rhinoeeros, or buffalo hide, and a large double-edged brass knuekle-duster, worn on the little finger of the left hand. For ormament they wear eopper, brass, and bead neeklaees, and the elders a large ring of ivory above the elbow. They are generally enveloped in folds of Ameriean sheeting, dyed a dirty brown. The women are dressed mueh like the Masai women, but without the endless iron eoils worn by that tribe. No man is considered of any importanee unless he has litled one of another tribe, after whieh he is allowed to grow two little tufts of hair on the top of his head. On the death of a Galla his son sueeeds to his possessions, with the exeeption of his hut and wives, whieh go to the brother. The brother on formally taking possession eeremoniously enters the hut and thus addresses the supposed spirit of the late owner: "Come out, old chap; you've had your day, now I'll have mine."

In eharaeter they are deceitful, treacherous, and obstruetive to a degree, and at present live on the mild and generous Wa-kopomo, who aeknowledge them as their masters. The Wa-sania, equally well known as Wa-boni and Wa-tai, are a tribe of hunters, living entirely on the produets of the ehase, their only weapons being bows and poisoned arrows. They also make use of pits for entrapping game. They acknowledge the Gallas as lords of the country, and when they kill an elephant have to give up one tusk to them.

The Wa-kopomo (people of the Kopomo, i.e., Tana river) are a negro tribe living on the banks of the river; a peaceable and industrious raee, cultivating large quantities of the ordinary native produets, and in some places rice. They are exeellent boatmen, using dug-out eanoes of all sizes, large quantities of which may always be seen opposite their villages.

Their villages are built on high grounds on the banks of the river, and on the land side are surrounded by strong stoekades, every possible aeeess to whieh is guarded by invisible pits, to entrap any of the marauding Somalis or Masai. They are vel'y 
expert in catching fish in every way, but their favourite method is to form a line and march slowly through the swamps bordering the Tana, prodding in all dircetions with their fish-spears as they proceed. In this mamner they capturc very large quantities of fish, especially a species of silurus which run up to seven or eight pounds.

The Somalis live north of the Tana, and rarely come so far soutl as the river, except in the height of the dry season to water their cattlc, or occasionally in slave-raids on the Wakopomo and Gallas living near the river. The former they raid on for slaves and the latter to take their cattle. They are a fine race, much resembling the Gallas, but hardly so dark, with very much the same customs, and are increasing yearly in power, Being, however, Mohammedans, they are in some respects rather more enlightened.

On Septcmber 28 th we made an early start from Golbanti, and after two hours' marching encamped on an arm of the Ashako Babo, which I believe is the Galla for the Pelican Lake. This is a fine shallow piece of water, abounding in water-birds and a few hippopotami, some ten miles long and a mile and a half in its widest part. Here we spent the middle of the day, to enable the men to cook their food and lay in a supply of water, as we knew we should have to cncamp in the dry bush that night. At 2.30 we started, and after two and a half hours' extremely hot march encamped in an open place in the bush. Next day we marched about three hours to my farthest camp of 1885 , shooting at some topé on the way without success. We were, however, more successful in bagging seven vulturine guineafowl on a little hill, which was simply covererl with these birds, sand-grouse, and partridges. In the evening I shot a topé and wounded another, and Hunter shot a water-buck (izur u).

The next day we halted, and all went out shooting in different directions. Pursuing a wounded topé I cameacross Greenfield, who informed me he had seen two fine lesser kudu, but had not seen my wounded animal. On separating again I found the wounded topè and another, both of which I killed. Greenfield also shot a 
third, and on returning to eamp found Hunter had shot three and a great bustard. Being seedy in the night, and the ehanee of any further varieties of game being remote, I resolved to stop in eamp. Greenfield and Hunter, however, went out; the former shot two topé and the latter a kuru (water-buck). At twelve o'eloek Martin and During arrived with the small dhow and eanoes. We then settled that they were at once to go oul and meet us next day at a place ealled Ngatama. We started next morning from our eamp near Mingala, intending to join the boats at Ngatama. After marehing three and a half hours I asked where Ngatama was, and 1 was told that it was eonsiderably to our right, the other side of an almost impenetrable swamp. I therefore sent a letter to During telling him to go on to Déra, which I was told would be the next place at which we slould toweh the river. We then marehed on for another two hours to a place where the Gallas said there was water. After hunting about for a long time in the thick bush it was at length found, and the men proeeeded to eook their food. They were, however, so long over it that we only made another hour and a half that evening, and eneamped in the open. 'The day following, after three hours' mareh through thiek bush, we emerged on a eonsiderable-sized pieee of water eovered with Wa-kopomo fishing. During the rainy season, when the Tana is at its height, this piece of water is connected with it. We stopped here during the lieat of the day under some shady trees, and marehing during the afternoon, reaehed the l'ana. Here we settled to await the arrival of the boats, but the ehief of Koso, the principal village of the Déra distriet, having invited us to his village, we next evening marehed there, and eneamped in his plantations. The ehief appeared well disposed, and said he wonld get us three guides for shooting next day.

Hunter and I went shooting in the morning, and having erossed the river in a eanoe, after a long tramp through a swamp reached dry land. We then separated. I shot a fair kuru and a topé, and Hunter a kuru.

During the molning I eanle aeross a party of Wa-kopomo 
spearing fish in a swamp; they appeared to have made a good bag, and had, besides a number of silurus, another speeies with a smooth mottled skin. Some of them would, I think, have sealed eight or nine pounds.

During and Martin arrived next morning, when I told Martin to at onee eommenee buying food, which the ehief had pronised me should be in readiness. On asking him where the food was, he denied that he had any, and altogether refused to help us in any way. We at onee saw that something was amiss, and after an investigation eame to the eonelusion that our Galla guides were endeavouring to stop our further progress into the interior by persuading the natives to "boycott" us. This is a very eommon praetiee in Afriea, and is oftell most effeetive against travellers with small earavans. Seeing the turn affairs had taken, I had our men drawn up before the ehief armed with their sniders, and told him that unless food arrived within two hours we should send our men into the standing eorn to help themselves, and pay him at the rate of a bulloek* a day, whieh would have been a fair rate of pay for food for our enravan. The Galla guides were threatened that in ease of any further trouble they would have stones fastened round their neeks and be thrown into the river.

This demonstration had a very good effeet, and food began to eome in, which we eontinued to buy during the afternoon, and next morning it eonsisted of riee (mpunga), maize (mahindi), and small beans (iundi). In the afternoon we left During, who returned to Golbanti, and marehed up the southern bank of the river with our men and two days' supply of food, the rest being brought up the river in our enuoes.

The eountry about here eonsists of thiek evergreen bush and swamps eovered with high grass, extending from a quarter to three quarters of a mile on eaeh side of the river, after whieh the dry land is reaehed, which is either dry open plain or thiek thorny bush, in some plaees a mass of eactus and

* 'The expression of a bullock in Africa means generally the value of one in iron wire, eotton, or other trate grouds. 
aloes. This is the general appearanee of the eountry up the Tana; the soil near the river is exeellent, and anything eonld be grown.

On Oetober Sth we had a very eireuitous mareh, and at length eneamped in some thiek bush on the bank of the river; we had seen some $G$. Walleri on the march, so Hunter went out after them in the evening, but only sueeeeded in wounding one. I shot a wart-hog, but again was disappointed in his tushes, which were poor. We had a nasty mareh through high grass and palms next day, and had to eross the river twice in order to avoid the thiekest part of the bush, whieh was very dense. We at length eneamped under some thiek bananas, and had a very troublesome interview with the natives, which was renewed again in the morning. This is one of the largest villages on the Tana, and it appeared that, although by far the greater part of the population were Wa-kopomo, still there were some Gallas and some WVa-sania living there. The result was that we had to supply the ehiefs of eaeh with presents.

To eaeh of the two former we gave a small Austrian blanket, and to the Wa-sania eight hands of Americani. After this they supplied us with food and promised Wa-sania guides for shooting.

Their promises, however, were not kept ; so, after waiting about next morning, Martin had at last to go again to the village, and whenee after another hour he returned with some Gallas and Wa-sania. As we were now nearing Durani we kept a good look-out for game during the mareh, and were not disappointed, as we saw many kuru, and old elephant and buffalo traeks in all direetions. We halted two hours during the hottest part of the day for luneh, and then marehed on to Durani, whieh we reaehed in two hours. We saw many topé and kuru and some buffalo on the march, and killed several kuru, but what pleased us most was that we passed elephant-tracks not more thau two days old.

On the morning of the I ath we all went shooting in different direetions, Hunter and myself keeping to the north side of the river, and Greenficld erossing orer to the left. 
After a twenty ininutes' walk through rather high grass I eame aeross a good kuru (water-buek), whieh I shot, and then pushing on another quarter of an hour, emerger on the dry rising ground, whieh is distinguished by the natives from the moist alluvial soil along the river by the name "Barani." Here we at onee saw more Walleri, whieh I endeavoured to stalk, but. I think they saw my men behind. Anylow, something frightened them and they bolted. Going on farther, I wounded two topé, one of whieh was at one time aetually on its back, but they both made off and were lost in the bush. On my way home on the grass near the liver I saw many more herds of topé and shot another good kuru. Hunter eame in with the news that he had seen some lesser liudu, speeimens of whieh we were anxious to obtain. Greenfield, however, found the grass and palms so dense on the other side that he was obliged to return.

Next morning I started off to look again for the Walleri, of which I sueceeded in finding fresh tracks in the light sandy soil. Following these a little way, on eoming round the eorner of a bush I saw a buek looking straight at me. Sitting down, I took aim at his narrow ehest and fired. I immediately heard the "thud," the pleasantest of all sounds to the stalker, but to my astonishment saw the Walleri galloping off. He, however, only went a hundred yards and fell orer dead. On going up to him he proved to be a fine buek. This was a new speeies to me, and so particularly interesting. These animals are quite unlike any other antelope that I have ever seen, their extremely long neeks and eurionsly formed noses very mueh resembling those of the giraffe. Later on in the day I shot a female, with whieh I returned to camp and immediately set my men to work to skin it, as I had notieed this speeies was not represented in the Natural History Museum.

Hunter got on the fresh traek of some elephants, and while traeking them eame aeross a lesser kudu. Not wishing to r'un the ehanee of frightening the former, he let it off. The search for elephants proving unsuecessful on the way baek, he shot a wart-hog. 
Martin and I passed the afternoon in endeavouring to persuade our guides to go farther on with us, but all our efforts were unavailing. We were, howcver, lucky enough to persuade an old Wa-kopomo who had come into the camp to promise to show us the way for a few miles next day. We took the precaution to keep him in Martin's tent all night, in order to prevent the Gallas from tampering with him.

We did a short urarch next day under the guidance of the Wa-kopomo, and pitched our camp about half a mile from an almost descrted village, the people having nearly all run away some days previously and hidden themselves in the bush in consequence of a report that the Somalis were out raiding for slaves.

When, however, they heard that we had arrived and were peaceably inclined, they began coming back to the village. Greenfield shot a kuru on the march, which would certainly lave been lost had not the dogs bayed it in the thick bush.

On the 15 th, having $n$ guides, we took our compasses and went off into the bush, having previously taken a good general view of the country. We were successful in shooting two wart-hogs, one topé, and one kuru, and Greenfield also fired at a buffalo. Hunter and I had shot so many buffalo about the Masai country that we agreed, unless we saw something really grand, to leave them alone; indecd we had that year shot twenty-five really finc old bulls, besides one or two others killed at times entirely for the pot.

Next molning, on my return to camp with a particularly fine kuru, I found Hunter engaged in photographing the head of an animal which I had never seen before. He said that he had seen two of them, and after following them up for some miles succeeded in bagging one. This animal, on being shown to Dr. Giinther; has since been pronounced by lim to be an entirely new spccies. It is of a bright red colour, in some respects resembling a hartebeest, especially in regard to the length of its head, and about the same size, but hardly as high at the wither's, and has not the same action in moving. The horns of the female much resemble those of the male mpallah, but 
those of the male are very much thieker and not so much eurved. This speeies has sinee been christened Hunteri, after Hunter.

On October 17 we resolved to press farther on, and finding it impossible to get through the high grass and thick vegetation near the river, struck out at first at right angles for the "Barani." Here we began to follow up as near as possible parallel with the river. We soon got into some dense caetus, and after marching another hour we arrived at some thiek forest and some fresh elephant-tracks. Creenfield and Hunter went forward to reeomoitre, myself and the cararan taking a rest. Some two hours afterwards they returned, having found the river which we were in search of, but had got lost in retraeing their steps. We then pushed on, and lunched under the shade of some large trees. Later on in the afternoon we pushed on to the river, having reached which, I gave order's to pitch camp. It was here neeessary to elear away a lot of high grass. While the men were doing so I suddenly heard a great commotion and cries of "Nyolice, nyolia!" ("Snake, snake!"), and saw a man being led to me trembling and evidently in a very great fright. On inquiring I was told that the man, while clearing away the high grass, had been bitten by a large black snake. I at once examined his leg, and found the mark of the smake's teeth some four inches above the ankle. I proposed to the man to cut open a cartridge, place some powder on the bite, and at once fire it, so as to cauterise the wound; which I eertainly should have done to myself under the same circumstances. As he would not allow this, I administered ammonia, and gave him a good turn at my whiskyflask. After a quarter of an hour, nothing happening, I went into my tent, hut had only been there another ten minutes when one of my men came in to say the man was very ill and eomplaining of pains all over his body. I gave him more whisky and watched him for some time, during whieh he continued to tremble and perspired greatly. During the night he remained in the same condition, and was very ill next day. He, however, entirely recovered in three or four days. 
On the Isth, after ordering the men under Martin's guidanee to eross the river and piteh eamp near the village, which was half a mile higher up, I started off through the forest on the norther'n bank. I saw large quantities of erested guinenfowl, after whieh I sent the dogs. They, however, failed to tree any of them. I was very anxious to find here a striped bush-buek whieh Hunter had seen the day before. On getting out of the forest I erossed an open plain on whieh some topé and kuru were feeding. We then entered a lot of very thick eaetus full of the little $N$. Kirkii. There were game-paths here in all direetions, but I saw very little, and only killed a large wart-hog sow. On telling my guide to lead the way home, I had eonsiderable doubts as to the line he was taking, and on referring to my compass found that he was going nearly due east instead of south-west, in which direetion $I$ felt fairly confident was the river. My men seemed more inclined to trust the guide than myself, but I struek out what I eonsidered was the line, and at length found myself in the proximity of the river. Upon reaehing our new eamp at Connor, I found that Greenfield had killed an oryx and Hunter a Walleri; they had also seen lesser kudu, and seemed altogether to be rather pleased with their morning's exploration.

This turned out to be the pleasantest eamp that we had anywhere on the Tana. Om tents were pitched under a shady tree on a high bank of the river, and as the wind blew direetly across it, it somewhat tempered the hot dry air. We stopped here two days, and bagged three Walleri, two lesser kudu, and a Granti. Wishing to explore the eountry farther from the river on the north side, we, after considerable diffieulty, struek a bargain with four Gallas, who agreed to take us to a plaee where there was water and game abounded. The whole earavan had again to cross the river, a tedious and by no means safe proeeeding. We then, after an hour and a half's march, eliefly through long grass and forest, arrived at a large shallow pool of fresh rain-water. This turned out a good eamp for game, we in four days bagging eight Hunteri, five lesser 
kudu, one wart-hog, one oribi, one oryx, three Walleri, and some Kirkii. We might also, if we had felt bloodthinsty, have killed rhinoceros, buffalo, giraffe, and tope, but had bagged plenty of these before. It was here also that I saw the largest lizard that I crer saw in Africa. Our attention was first drawn to him by my dogs (which had been let loose to look for a wounded Walleri) suddenly baying at a small bush. On looking into it I saw the head of what I imagined was an enormous snake. It, however, almost immediately bolted out, and proved to be a brightly-coloured lizard of at least sixty pounds. My Gallas threw their spears at him and secured him. They, however, effectually spoilt his skin, which I much regretted.

On October 26 we left Comnor and marched parallel to a large ziwa (pool) for an hour and forty minutes entircly through bush; here we spent two nights, and bagged some wart-hog and lesser kudu. The chief excitement I had was after a wounded wart-hog that went to ground; we tried hard to smoke him out, but, I think, succeeded in suffocating him with the smoke. He was dragged out by my dog-boy Suédé, who had to crawl into the hole. An enormous number of longeared bats came out in the smoke.

Our next march took us along the river until we found ourselves opposite Little Mallalulu, and having scen some shady trees on the bank, we ordered the bush underneath them to be cleared away. This formed a very pretty camp on the high bank, and we had also the benefit of a cool wind that was blowing up the river. Several snakes were here killed in the camp, and one dropped off the bough of a tree umpleasantly near to our men's heads, who were engaged in pounding rice. After a rest, during the middle of the day we all went out shooting, but I was the only one who had any luck, which consisted of one lesser kudu with a poor head. The next day I shot a Walleri and a wart-log, but my friends were again unlucky.

The boats, which had had hard work against the heary stream, 
having at last reached us, we left on the 3oth, and marehed up opposite to Big Mallalulu, or at least the place where Mallalulu had been, as of inhabitants there were none. The path led through evergreen bush and trees to the edge of a swamp about I50 yards across, which liad to be crossed before reaching the bank of the river. Hunter, Greenfield, and Martin waded through it; but as the water was up to their chests, I selected two strong men to carry me over, which they did, I sitting with one leg on the shoulder of each, in which precarious position I at last reacled terra-firina, although we several times stuck in the mud. We then, after a wait of an hour for the boats, crossed in them to the deserted village. The inhabitants had all disappeared some weeks before in consequence of a report that Somalis were raiding on the river, and had, we heard, built another stockade in a stronger position lower down. The old chief turned up during the afternoon in my tent and began turning over everything on the table and asking what the different articles were. On asking what the pepper-pot contained I said snuff, on which he helped himself and went off. He, however, soon after returned looking very annoyed, and said, "Your suuff is mbovu (rotten); I do not like it at all!"

The next day I tramped over a lot of country, but only saw some giraffe and Walleri. Greenfield returued with a Hunteri and with the news of a puddle of water inland, which was very wclconie, as all the gaine secmed to live far away from the river, and we were particularly anxious to find some water inland to encamp at. Hunter, who stopped out all day exploring for water, brought home an oryx and a Walleri.

On the following morning we marehed for the puddle, and found any number of tracks near it. We had now reached the best shooting-ground that we came across up the Tana, and in the three next days bagged seven Hunteri, two eland, three Walleri, one lesser kudu, one oryx, and some Kirkii, and saw a few rhinoceros and buffalo.

We saw a great many tracks of elephants, some of then quite fresh, but for several days we could not manage to ccire 
across them. On the 5 th we went a short march, and in the afternoon went out shooting. I shot a lesser kudu and wounded another badly, whieh, however, got away. While returning I heard a heavy rifle fired in the distance, followed by several other shots. About an hour after dark Greenfield returned in triumph with an elephant's tail, and then gave us the length of its tusks. We were a little ineredulous about the latter, but he was, as we found out afterwards, quite correet. The following is his own account :-

Taya River, November 5.

Went out in the evening, and had sighted some tope and a single Hunteri bull, the latter of which I proceeded to stalk. I had not been erawling long when I saw them put their heads up and look in my direction and gallop off. On looking round I saw the eause of it, one of my gun-bearers was running towards me and beekoning in a very excited way. He had eome to tell we he had seen a big elephant feeding in the open and coming my way. I jumped up at onee and ran well below the wind, and sighted a single bull elephant feeding quietly half a mile from me. I got my seeond gun-bearer, and with a 577 and eight-bore went after him. I was in a great state of mind that Harvey, who was up the wind, would fire a shot and so frigliten him. I got up to about 150 yards of him, taking advantage of bushes, \&e. When going round a bush to have a look at him, I heard a great hiss within a few feet of me, and I saw a great snake standing up at me. I soon made tracks round the other side of the bush. The elephant now moved on, and was nearing some thin bush, so when he had his tail to me I moved on after lim, so as not to be too far behind, as it was now getting dusk. I had not got far, and looking round, saw that my gun-bearer with the seeond rifle woukd not budge an ineh. I went back, and at last got him to come on, and then got up to abont twenty yards of the elephant's tail. He soon turned round brondside to me, and I fired the eight-bore into the vertebræ. The first shot he swayed about. I quickly fired the seeond barrel at ame place, and he fell to the ground with a crash. I took the 577 and ran up to him and fired several shots into the back of his head to finish him. He was a grand bull. The tusks of this elepliant measured 8 feet 3 inches and 8 feet, and weighed $8 \mathrm{r}_{2} \frac{1}{2}$ and $80 \mathrm{lbs}$. 'They were hollow a long way up, or else would have weighed considerably inore. This would prove that he was not a very old animal. 
Hunter went next day and photographed the tusker, whieh was an immense beast. The Gallas spent several days in eutting up the meat and drying it in the sum, and the whole country was a perfect mass of vultures, who eovered every bush and tree near the careass.

There were a eonsiderable number of eland about this eountry, but personally I only sueeeded in shooting a cow, and very nearly lost my eye while shooting it. I erawled up to within seventy yards and fired from behind a small bush, when the stoek broke, short off at the grip. The shot had no result on the eland, whieh simply stood broadside looking in my direction. Being very anxious to shoot it, and as it presented sueh a splendid ehanee, I held the rifle out in front of me and fired. The result was, that the reeoil sent the splintered end of the stoek on to my faee, cut my eyebrow badly, and sent me over baekwards, whieh perliaps was not to be wondered at, eonsidering I was firing a 577 express with seven draehuns and an extra long solid bullet. I had, however, the satisfaction of seeing that the eland was still more damaged, and of seeing it soon after fall over dead, the bullet having hit it in the ribs.

Ramasan then eame up, and on my telling lim what had happened, he said that the stoek had been eraeked ever sinee the rifle was knoeked out of my hands by a buffalo in the Masai country.

We eontinued having the same kind of sport, gradually returning down the left bank of the river, until the 23rd, when I finished my sport in Africa, at least as far as big game was eoncerned, by bagging an oribi and a eoek ostrich, the latter by a splendid fluke at a good three hundred yards from the shoulder. These made up twenty-seven different speeies of big game that I had shot in Afriea. We purchased some more canoes, and lashed the smaller ones two and two, so as to prevent any chanee of their being upset. I only wish we had done the same with our biggest, whieh was heavily laden, and had some seven or eight men sitting on the goods. It began to roll 
heavily directly it started, and before it had gone fifty yards eapsized. Unluckily for Hunter, most of his things were in this boat, ineluding his rifles. Everything was, neelless to say, in a fearful state when reeovered, but nothing of value, exeept one snider carbine and some boots, were lust, all the other things being brought up by our men, who dived for them.

On the $27_{\text {th }}$ we arrived safely at Golbanti, having eome a great pace down-stream. The only loss to the expedition this trip was that of three dogs, who died from bites of the tse-tse fly. As we had now rather more time on our hauds than we knew what to do with, and as we had unpleasant aceounts of the fighting between the Germans and the natives farther south, we resolved to wait at Golbanti nine days instead of waiting so long at Lamu for the steaner. This was not particularly pleasant at this time of year, as the eountry was flooded all round the mission-house, and it was impossible to get on to any shooting-ground without wading for over twenty mimutes through a black muddy swamp, with water up to the chest. This, however, we had to do, and amused ourselves shooting quail, partridges, \&c., of which we made some fair bags. The mosquitos were also fearful, and I had to retire under my mosquito-eurtains immediately after dinner every evening.

During the last month up the river the weather had been very hot, in the middle of the day the thermometer varying from $93^{\circ}$ to $98^{\circ}$ in the shade. From Golbanti we found our way by Charra into the Ozi river, and from the mouth of that overland from Kapini to Lamu.

Yours ever,

ROBERT G. HARVEY. 
GAME SEEN UP THE TANA RIVER.

Lion.

Leopard.

Hyana (spotted).

Canis latcralis.

Elephant.

Rhinoceros.

Zebra.

Hippopotamus.
Wart-hog.

Buffalo.

Giraffe.

Eland.

Oryx-beisa.

Lesser Koodoo.

Water-buck.

Senegal.
Hartebeest.

Damalis Hunteri.

Gazella Walleri.

Gazclla Granti.

Oribi.

Neotragus Kirki.

Duilier. 


\title{
A P PENDIX I.
}

\section{LIST OF FAUNA FOUND CHIEFLY IN THE PLAINS ROUND KILIMA-NJARO.}

\author{
COMPILED BY H. C. T. IIUNTER.
}

Lion. Felis leo (Swahili, Simba). Common to the open plains fringed with bush and near belts of bush by rivers and swamps. They were generally seen in pairs or troops of four to seven. I) uring our last expedition $\mathrm{G}$ - saw ten together. Though heard round the camp nearly every night, they were not often met with. Zebra and buffalo seemed to be their favourite prey.

Leopard. Felis pardus (Swahili, Chui). Common on the monntain up to about 6000 feet elevation, and in the forests of Taveta and Kahé. They live prineipally round the villages, killing many goats. I have noticed in Africa that the leopard nearly always puts the remains of his lill up a tree, probably to prescrve it from hymas. On one oeeasion I saw the skeleton of a fine male lesser kudu hanging from a forked branch, and we have several times seen a leopard descend from a tree. They are extremely bold. One, who had for several days been carrying off undried heads, \&c., which were stored in a shed adjoining our house in Taveta, I caught in a lion-trap, during dimner, set within fifteen yards of our table.

Felis serval. Several times seen and killed in the grassy plains at the foot of the mountain. From Mandara, on the mountain at about 5000 feet, I obtained a melanism of this species, killed by the Wa-êga. Here melanotie varieties of the serval must be often met with, since they have the name "Nzulu" for it. In the Natural History Museum there is also another 
blaek skin brought from South Afrien by Mr. Selous; in his speeimen the spots are easily distinguishable in a strong light.

Cineetah. Cyncolurus vonator. One was shot by Mr. Jackson near Kahé, only one other was, I believe, met with.

Viverra Civetta. Seen in Taveta.

Genetta Tigrisa. Very often eanght in traps in Taveta, where it used to make great havoe with the poultry.

The Spotted Hy insa. Hyana crocuta (Swahili, Fisi). Very eommon everywhere on the plains, but not extending far up the inountain.

The Striped Hydexa. Hyana striata. Tery seldom seen. One was shot on the plains.

Caxis lateralis. Common on the plains.

Wild Dog. (Swahili, Mbwa Mwitu.) Two large paeks were twiee seen on the plains near Useri, and we onee met with them near Maūngu on the mareh down to the eoast.

Another small dark-eoloured fox is often seen on the plains, generally five or six being together.

Hare. Lepus capensis (Swahili, Sungora). Often seen and killed on the plains.

Hyrax Brucei (Kičaga, name Kivuburu). Very eommon in the forest on Kilima-njaro at high elevation. They live in holes in the trees, and are very noisy at night. The Wa-čaga, who eatel many of them alive, value their skins very mueh, sewing several together and making a handsome eloak.

Elephant. Elephas Africanus (Swahili, Tembo-more often, Ndovi). In the dry season the elephants live in the thick damp forest of Kilima-njaro from 6000 to gooo feet. Abore this height we never observed any tracks. In the rainy season they descend the mountain, and are then fairly numerous in the thiek bush under Sina's or Mandara's, but are then much hunted by the Wa-ramba, who at this season eome all the way from U-rambani to humt, Mandara yenrly enploying some to hunt for him. They use poisoned arrows. In this bush the sportsman must keep a sharp look-out for elephant pitfalls, whieh are very numerous and ingeniously eoncealed; 
but from what I eould hear, very few elephants eome to grief in them. Elephants in the wet season wander along the banks of the Kikavo and Weri-weri rivers to the Sogonoi hills, and to the bush around Lake Jipé. At all seasons of the year there is generally a lierd in the Kahé forest.

Rhinoceros biconxis (Swahili, Kifaru). The rhinoeeros is partieularly eommon in the plains to the east and north-east of Kilima-njaro, but is also found nenrly everywhere. In one day's mareh we onee eounted sixteen. They feed prineipally in the bush on twigs, and lie out during the day on the open plains. The are usually found singly or in a family, eonsisting of a full-grown bull and eow with a half-grown calf. Their sight is not grool, but they have great power's of smell. Although the people of Useri said they did mueh damage to their banana plantations on the mountain, we never saw their traeks at that elevation.

Every diversity in size and shape of horns is met with, the baek horn often being longer than the front one. The horns of the best bull killed measured, front horn $29 \frac{1}{2}$ inehes, baek horn I 9 inches; best cow, front hor'n 32 inehes, baek hor'n 2 I inehes.

Burciell's Zebra. Equus Burchclli (Swahili, Punda Milia). Very eommon everywhere on the plains in immense herds, and often seen in the thin thorny bush.

Hrppopotanes. Hippopolames amphitius (Swahali, Kiboko). There are several sehools, in Lake Jipé, and some are generally found in every large swamp. One was killed hy the W'Arusha with spears in the Kikavo river after an exeiting hunt. At night they often travel three or four miles to feed.

WART-IIOG. Placoccerus (Swahili, Bango or Nguruwe). Common everywhere on the plains, prineipally in the thin thorny bush. Great damage is done by pigs to the Indian-eorn erops in Taveta. Whether this is done by a bush-pig or the wart-hog I was unable to aseertain, though Mr. Johnston states that wart-hogs are found on Kilima-njaro up to Sooo feet. We never observed them or saw any tracks of them.

Bufralo. Bubalus caffre (Swahili, Mbogro, and on the eoast 
Nyati). The buffalo is very eommon on the plains, but we ourselves never observed it or saw tracks of it on the mountain; but Dr. Abbott, who spent many months there, told me that lie had seen fresh traeks of it at about I0,000 feet. They are generally found in immense herds; but the old bulls are more often found by themselves or in two and threes. During the lieat of the day they retire to the thiek bush, feeding on the plain in the early morning and evening. The horns generally appear to be mueh finer than those of the South Afriean buffalo.

Giraffe. Giraffa camcloparlues (Swahili, Twigga). Very eommon round Taveta, and generally met with everywhere in the thin bush.

Eland. Orcas conna (Swahili, Mpofu). The eland is rather loeal; there are a fair number to the south of the mountain, and also on the plains to the south of Lake Jipé; perhaps they are most numerous to the north-east of the mountain. They travel great distanees from water. Both males and females are all more or less striped. The old males are readily distinguished by their dark slaty-blue eolour, and are generally found by themselves, The horns of a bull arerage about twenty-five inehes in length, those of a eow twenty-six inches, the latter being mueh thinner.

Kudu. Strepsiccros kudu. The large liudu was only seen by us on two or three cecasions on the Useri river, and was never shot. Mr. Johnston states that it is by no means rare on the mountain, and that it ranges up to 14,000 feet, but though we on several different oecasions eamped at 9000 feet, aseending to over I 4,000 feet, and explored the slopes on the south side in every direction, we never met it. At over 14,000 feet I saw old tracks of a large antelope, and picked up at 9000 feet, by the side of an old disused game-pit, the crumbling eore of an old hom, whieh I took to be that of a kudu. However, it must be very rare, if it exists at all on the mountain, and as Mr. Johnston also states that sable antelope are plentiful, of whieh speeies there are certainly none in those parts, it is very possible he may have been again mistaken as regards the kudu. 
Lesser Kudu. Strepsiceros imberbis (Swahili, Kungn?) The lesser kudu is found in the bush round Taveta, and was killed on the Kikavo river, near the Sogonoi hills; but though one of the most eommon antelope up the Tana river, it is seldom met with near Kilima-njaro, and seldon leaves the bush. It is eommon at a place ealled Mererani, on the eoast betweeu Mombassa and Lamu. Also seen at Maūngu. Measured in a straight line from base to tip, the horns of a fullgrown male should average seventeen inehes.

The Bush-Buck. Tragelephns sylvatieus (Swahili, Mbawara? or Parahara?). The bush-buck is found in or near the edge of bush by rivers, never many hundred yards away from water. All the bush-buek killed here liad a bare spot on the neek, as if rubbed by a eollar. A good pair of horns shot near Taveta measure eleven and a half inehes.

Oryx. Oryx-beisa (Swahili, Cheroa). Plentiful on the plains and in thin thorny bush. Perhaps most eommon near the Useri river, but very selilom seen to the south-west of the mountain. Also found in great numbers south of Lake Jipé. The horns of a female measure from thirty to thirty-two inehes; those of the male are thieker, but a few inehes shorter.

Coke's Hartebeest. Alcelupluzs Colei (Swahili, Kongoni). Quite the most eommon antelope on the plains, being found in every direetion in immense herds. Horns vary much in size and shape. A pair belonging to a male measure eleven and a half inehes from the top of the frontal bone to the tip of the horn, with a spread from tip to tip of seventeen and a half inches.

Tire Brindled Wildebeest. Connochetes Gun (Sivahili, Nyumbu). Found prineipally to the north-east of the monntain in large herds. Also on the plains near the Sogonoi hills.

The Mpallah. Apyecros melampus (Swahili, Swalah). Common everywhere in thin bush and on the plains. A good pair of horns measmre twenty inehes from the base to tip in straight line.

Tine Water-BUCK. Cảus Ellisiprymnus (Swahili, Kuru). Found everywhere near rivers and marshes, and is rery fond 
of stony hills near water. Horns measure from twenty-five to twenty-nine inches along the inside curve.

REED-Buck (Swahili, Porhé). This antelope obtained by us differs from the South African one, and will probably prove to be a new species; the horns in this are thicker and more bent forward at the tips. It is found in the early morning and evening fecding near the edges of rcedy swamps, and when disturbed immediately runs into the rushes. It was very common round a large swamp near Mikunduni, in the Masai country, south-west of the mountain. It is of a light yellow colour, the hair being rather long and coarse.

Grant's Gazelle. Gazella Granti (Swahili, Swarah). Common everywhere on the open plains. One male generally accompanies ten to fifteen females. It is most common in the direction of Useri. The longest pair of horns obtained measured thirty inches, but twenty-seven inches is a big head. Those of the best female measurcd seventeen inches along the inside curve.

Thomson's Gazelle. Grazlla Thomsoni. This handsome little gazelle, discovered by Mr. J. Thomson during his trip through Masai-land in I883, was found in large numbers in the plains in the Masai country to the south-west of the mountain, and we also camc across it on the boarders of the Masai country at the south end of the Kyulu mountain, but they are not found on the south side of the mountain between these two points. I have seen them mixing with Gazclla Granti, the female of which at long range, though larger, is easily mistaken for a male Thomsoni, both having the broad black stripe on the side. They are generally in small herds, one male to about ten females. Horns of a male measured fourteen inches along the curve, with a sprcad from tip to tip of thrce and three-quarter inches.

Waller's Gazelle. Gazclla Wallcri. Very rare near Kilimanjaro, though numerous up the Tana river. It frequents thin thorny bush on red sandy soil. One was killed near the south end of Lake Jipé. A good pair of horns measured fourteen inches along the curve. 
Steinbock. Nanstragus tragulus (Swahili Ishah). Tery often seen in the long grass on the plains. Horns average from three to five inehes.

The Dutker. Cephalophus Mergens. Though not eommon, is found generally singly on small stony hills.

On Mount Kilima-njaro, at an clevation of 10,000 feet, we killed a small antelope resembling the duiker, but with a very long thick coat. We also saw it as high as I 3,000 feet.

There is also on Kilima-njaro another Cephalophus of a dark red colour, but mueh larger than the duilier. A male of this probably new antelope has been killed by Dr. Abbott. Mr. Jackson also killed a Cephalophus in the forest of Kahé.

Neothagus KIRkil. This little animal, not as large as a hare, is very eommon in bush interspersed with alocs on dry red soil. It appears to subsist without water, being often found many miles away from it.

When Herr Ehlers successfully climbed Kilima-njaro in I 888 , he observed at about io,ooo feet a herd of large antelope, which he described as of a red colour, with rather long horns sweeping back; but until this antelope is obtained it will be impossible to determine what it is. The sable and roan antelope mentioned by Mr. Johnston as being eommon round Taveta were never seen by any of the party, though erery bit of the country had been hunted over at all scasons of the year, nor did the natives know anything about them or recognise pictures of them. The sable antelope is found up the Wami river' opposite Zanzibar, but, from our experience, does not eome north of that.

Damalis Huxteri, which was first seen by us on the I6th of October i 888, has turned out to be a speeics new to science. It is considerably larger than an mpallal, but stands rather lower than Hartebeest Cokei. It is of a uniform red colour, with the exeeption of a white horse-shoe mark on the forchead and a rather long white tail. The horns of the male somewhat rescmble the horns of an mpallah, but are much thieker; those of the female being of much the same thickness. In length, 
ineasured straight from the tip to the base, an average good head would be twenty-two inches, with a spread at the tips of sixtecn inches. The horns of a fcmale would measure eighteen inches, with a spread of eleven inches from tip to tip. Though not sloping away at the hindquarters like a hartebcest, it resembles it in its heavy gallop. It is only found on the north bank of the Tana, and was first met with at a place called Durani, about I 50 miles from the mouth of the river. It goes about in herds of from five to twenty on the plains and thin bush.

\section{LIST OF THE GAME-BIRDS COLLECTED NEAR KILIMA-NJARO.}

Pteroeles gutturalis is the largest of the sand-grousc found round Kilima-njaro, and is much more difficult to approach within shot of than cither of the two following species, but large bags might be made by waiting near thcir drinking-place between eight and nine in the morning. On June 4, I887, specimens of all three species were collected as they came to driuk at a pool on the Useri river in very large numbers. Nests and eggs were found in July.

Pteroeles decoratus is confined more to the red sandy soil in very thin bush.

Pteroeles exustus can be distinguished by its long pin-tail feathers, and is perliaps the most common of the threc specics.

Nrmida coronata is the guinea-fowl most often met with round Taveta. Very large numbers are found near the River Lumi and in cvery part of the country near Kilima-njaro. Can be distinguished from Pucherani and Vulturinum by the horned crest on the top of its head. If chased by a dog they at once take to the trees, when very good sport can be liad with a rook rifle.

Numida mitrala. I camnot be sure that we have met with 
this guinea-fowl, which mueh resembles Coronata, but give it on the authority of Dr. Fiseher.

Numida pucherani is a very handsome guinea-fowl, confined to forest by banks of rivers. It was seen in the forests of Taveta and Kahé, and also in forest by the banks of the Tana liver.

Acryllium vulturinum. The vulturine guinea-fowl is found along the Useri river, on the dry red soil covered with thin thorny bush; also between Maungu and Taro. It is partieularly plentiful at the Tana river, being the only guinea-fowl exeept Pueherani observed by us up there.

Coturnix histrionica is the largest of the two kinds of quail met with near Kilima-njaro, and at certain seasons of the year is exceedingly numerous. At Ndara, in Teita, in Deeember I 886 they were flushed at every step along the march. They were also very eommon on the Tana river in Deeember I 889.

Turnix lcpurana is a small yellow button-quail, often flushed singly out of long grass, but is not common.

Francolinus Granti. A small francolin, very common on the Useri river especially; also found round Taveta.

Francolinus Schuctti. A large dark-brown bird with red bill. Large numbers are caught alive by the natives on Kilina-njaro at about 5000 feet. They live in the dense scrubby bush on the mountain, and are rarely seen.

Francolinus Hildcbrandti, Cabanis, and Francolinus altumi, Fischer and Rcichcnow. That these are one species there is little doubt. Both Dr. Abbott and I myself sexed a great number of these birds; all the Hildebrandti turning out to be females, and all the Altumi males. The Wa-čaga boys daily brought in many of them to camp alive, probably caught in the same trap, and at least fifty birds were sexed with the above result. They also, like Schuetti, live in the thiek low bush, and were rarely shot.

Francolinus Humboldti. Fairly eommon near Golbanti, about fifty miles from the mouth of the Tana river, but not observed in the Kilina-njaro distriet. 
Francolinus coqui. Collected near Doruma, but not seen near Kilima-njaro.

Ptermistes infuscatus. The most common game-bird round Taveta, being also seen all the way down to and along the coast between Mombasa and Lamu, and also up the Tana river. Easily distinguished by its bare yellow throat.

Otis kori. This large bustard is most common on the plains near Useri; also seen at the Tana river. They afford good sport with a rook rifle, but are too wild to be approached within gunshot.

Otis canicollis. This florican is common on the plains and in thin bush.

Eupodotis maculiponnis. Found near the Useri river.

Plectoptcrus Gambonsis-the spur-winged goose. Once seen and killed on a swamp to the east of Taveta.

Chenalopex AEyptiacus. The Egyptian goose is common on all the fair-sized rivers and swamps. Also very common on the Ashakababa lake on the Tana river.

Sarcidionis Africanus is a large white-breasted duck, and was collected on a swamp to the east of Taveta.

Pacilonctta erythrorynchus. Collected near Taveta.

Nettopus Auritus. This handsome little cotton teal was observed on a swamp near Taveta, and was collected by Jackison.

Anas flavirostris.

Dendrocygna viduata. Very common on the Tana river, but not observed near Taveta.

Struthio Danaoides. The ostrich is found on most of the plains, and often wanders into thin bush. As many as fifteen or twenty are often seen together, but the fully adult birds are found generally in pairs or singly. Very common up the Tana river. 



\section{A PPENDIX II.}

\section{ENGLISH-SIVAHELI VOCABULARY OF USEFUL WORDS AND.PHRASES.}

\section{Pronunciation as in Italiun.}

\section{ABBREVIATIONS.}

$v=$ verb, infinitive or imperative.

$s_{.}=$substantive.

$a .=$ adjective.

pron. =pronoun.

prep. = preposition.

eonj. = conjunction.

interj. = interjection.

$r \cdot c .=$ relative pronoun.

inter. = interrogative. sing. = singular.

plur. = plural.

$\check{e ̆}_{\text {. }}=$ sh, as in moči, ̌̆aga, pronounced noshi, shaga.

$m$, before a consonant $=u 1 n$, as in mtu, pronounced untu.

$n$, before a consonant $=e n$, as in ngema, pronounced engema.
A.

Above, adv. and prep., juu.

About, adv. and prep., karibu; (all round) pande zoté. What are you about? wafanyajé?

Absent, $v$. He is absent, hayuko.

Action, s., tendo, plur. matendo.

Afraid, v., ogopa.

After, afterwards, aclv. (of time), baadaye.

Ago, adv., zamani (i.e., long ago). How long ago? tangu lini?

Aim, to shoot, v., kulekeza bunduki.

Alike, a., sawasawa, mamoja.

Air, s., hewa.

Alive, a., zima.

All, a., oté.

Allotment, s. (cultivation plot), shāmba.

Alligator, s., maamba.

Along, adve, liando ya. Go along! ondoka!
Already, adv. (before), mbele. He has gone already, amekuisha kwenda.

Always, adv., siku zoté.

American cloth, s., amerikano.

Among, prep., katikati ya.

And, conjc., na; and not, wala; and you, nawe; and he, naye; and it, nao. He got up and went, aliondolia akaenda.

Anklet, s., mtali.

Animal, s., nyama ; (small), mdudu ; (wild), nyama ya invitu.

Ants, s., clungu ; (red, biting), siafu ; (white), mchwa.

Any, $a$., $y^{\prime \prime}$ yote. I do not see anything, sioni kitu.

Apart, far off, $u d v$., mbali.

Apartment, s. (house), clumba.

Ape, s., nyani.

Arab, s., Niwarabu.

Arm, s. (two-feet neasure), mkono

Arms, s. (weapons), selaha. 
A round, adv., pande zoté.

Arrow, s., mshale.

Asleep. He is asleep, amelala.

Ass, s., punda.

At, prep., kātylkā. At once, marra moja.

Away. I am going away, nakwenda zangu.

Axe, s., shoka.

B.

Baby, s., mtoto.

Back. Go back, rudi.

Bad, a., baya, ovu, singema.

Bag, s., nufuko ; (small), kifuko.

Bait, s., chambo.

Bale out water, v., vuta magi.

Ball, s., pila, tufe.

Bamboo, s., mwanzi.

Banana, s. (plant), mgomba ; (fruit), banana.

Bandage, s., kitambaa.

Baobab, s. (tree), mbuyn ; (fruit), buyu.

Bar, s. (iron), chuma; (wood), mti.

Bar, v. (a door), pingia.

Barrel, s. (gun), kasiba.

Barter, 2 ., badili.

Bat, s., popo.

Battle, s., vita, mapigono.

$\mathrm{Be}, \imath$, wa ; (be with), wa na.

Bead, s., ushanga.

Bean, s., kundi.

Bear, s., dubu.

Beat, r., piga.

Beautiful, a., zuri.

Bed, s., kitanda.

Bee, s., nyuki.

Beer, s., pumbé.

Bell, s., kengele.

Belly, s., tumbo.

Below, adv, and prep., cini.

Between, adv. and prep., hăti kāti.

Big, a., kubwa.

Bill, s. (of bird), mdomo.

Bind, $r$. (tie up), funga.

Bird, s., ndege.

Bite, $r_{\text {, }}$ uma.

Bitter, $a$, chungu.

Black, a., eusi.

Black-mail, s., hongo.

Blood, s., hema, damu.

Blow, s., piero.

Boar, s., nguruwe ndume.

Boat, s., masluna, felncca.

Bone, s., mfupa.

Book, s., kitabu.

Boot, s., kintu.
Bottle, s., chupa.

Bough, s., tawi.

Box, s. (large), sanduku ; (small), mbiveta.

Boy, s., mtoto mume.

Brass, s., shaba.

Bread, s., mkate.

Bridge, s., daraya.

Bring, v., leta.

Brushwood, s., koko.

Bucket, s., ndoo.

Buffalo, s., nyati, mbogro.

Bullet, s., risasi.

Bundle,
Burden, s. (load), mzigo.

Busls-buck, s., parahara, mbawara?

But, eonj., lakini, illa.

Butter, s., siagi, samli.

Buy, $v$, nunna.

By, prep., na; (near), krribu ; (by means of), kwa.

C.

Calabash, s., buyu.

Camp, s., kituo.

Cap, s., kofia.

Caravan, s., msafara ; (journey), safari ; (porter), inpagazi, hlur. wapagazi.

Carcass, s., inzogra.

Care. Take care! angalía.

Carpet, s., zulia.

Carriage, s., gari.

Carry, v., chnkūa.

Cask, s., pipa.

Cat, s., paka.

Catch, $v$. (fish), vua samaki.

Centipede, s., taandu.

Chain, s. (ornanental), mliufu.

Chair, s., kiti.

Charm, s., talasimu.

Chicken, s., faranga, kuku.

Chief, s., jumbe.

Child, s, mwann, mtoto.

Claw, s., kucha.

Clean, v. act., takasa.

Close, $v$. (a door), shindika.

Cloth, s., see American.

Club, s, rungu.

Cocoa-nut, s., mmazi ; (tree), nazi dafu, (nut).

Cuffee, s., kowa.

Cold, s., baridi ; adj., a baridi.

Come, v., ja. Come back! rudi! Cone here! njoo! I im coning, anakouia. $\mathrm{He}$ is coming, atakouia.

Consul, s., barozi. 
Cook, v., pika.

Cooking-pot, s., sufaria.

Cord, s., kamba.

Corn, s. (Indian), mahinde.

Cost. What does it cost? chapataye?

Council, s., baraza.

Cow, s., nghomibe.

Cubit, s., sce Arın.

Cut, $v$. (cut down), kata.

\section{D.}

Dandy, s., muladadi.

Date tree, s., mtende; (fruit), tende.

Day, s., siku. To-day, leo.

Dead. He or it is dead, amekufa, amekuisha.

Deer, s., paa.

Devil, s., shaitani.

Desert, s. (bush), nyilia.

Dhow, s., chombo.

Directly, adv., sasa hivi, marra moja.

Dinner, $v$. (bring dinner, \&c.), leta chakula.

Do, v., tenda. It is done (finished), amekuisha. That will do, vass, bassi. How do you do? yambo, salaam! subalkheri!

Dog, s., inbwa.

Dollar, s., reale (3s. 4d.).

Donkey, s., see Ass.

Door, s., mlango.

Dove, s., hua.

Down, alve, sce Below.

Drunk, $r$. (to be), lewa.

Duck, $v$, battah.

Dust, s., vumbi.

Dye, s., rangri.

E.

Each, a. (every), kulli ; (singly), moja. moja.

Eagle, s., tai.

Ear, s., sikio.

Early, adr., mapema, alfajeri.

Easily, adv., rahisi.

Egg, s, yayi.

Eilephant, s., tembo.

Enemy, s., adui.

Enough, see 1)o.

Entrails, s., mitumbo.

Equal, $a$., sce Alike.

Eland, s., mpofu.

Evening, s., jioni.

Expensive, $\boldsymbol{\alpha}_{0}$, ghali.

Eye, s., jicho, plur. macho.
F.

Fair, a., sec Beantiful.

Far, ad $v$., mbali.

Farewell! kua heri.

Fast, a., upesi, hima.

Fasten, 2 ., funga.

Fat, s., mafuta ; (of persous), nene ; (of animals), nono.

Father, s., baba.

Female, a., -ke ; (animal), jike.

Fever, s., homa.

Fierce, a., kali.

Fig, s., timi.

Fight, $v$., pigana.

Fight, s., sce Battle.

File, s., tupa.

Fire, s., motu.

Firewood, s., limin ; see Brushwood.

Fish, s., samaki.

Flag, s., bandiera.

Flesh, s., nyama.

lilour, s., unga

Fence, s. (thorn), boma.

Fly, s., inzi.

Food, s., chakula, yakula.

Foul, s., mjinga, nipumbafu.

Foot, s., mguu.

Forest, s., mvitu.

Fowl, s., see Chicken.

Friday, s., Juma.

Friend, s., rafiki, mzishi.

Frog, s., chura.

Fruit, s., tunda, zao, plur. ma-.

Fuel, s., brushwood.

Future, $a_{\text {., a }}$ baadaye. At a future time, batadaye.

G.

Game, s. (dance), mchezo.

Gate, s., sec Door.

Grazelle, s., see Deer.

Gently, adv. (softly), pole pole.

Get, $v$. It is to be got, inapatikani. Get in, $\imath$, injia. Let us get on, haya. Get out of the way, epa, toka.

Ghee, s., see Clarified butter.

Giraffe, s., twigga.

Give, $r$., toa, deh!

Go, v., enda. Go away! see Along. Go back! sce Come back. Go on ! endelea mbale.

Goat, s., mbuzi.

God, s., maūngu ; (Masai), ngai.

Good, u., -ema. Good ! ngema ! 
Good morning, see Do (How do jou do ?).

Good evening, masalkheri.

Good-bye, liua lieri.

Goveruor, s., liwali.

Grain, s. (millet), intaua.

Grass, s., inayani.

Gratitude, s., shukrani.

Grease, s., see Fat.

Great, a., see Big.

Guinea.fowl, s., lianga.

Gun, s., bunduki.

Gumpowder, s., baruti.

Granti, s., swarah.

\section{H.}

Half, s., mussa, nussu.

Hammer, s., nyumlo.

Hand, s., sec Arm.

Hard, a., gumu.

Hare, s., sungura.

Hartebeest, s., kongoni.

Haste, s., liaraka. Make haste! haya upesi ! hima!

Hawli, s. (vulture), nwewe.

Head, s., kitwa, ketchwa.

Heavy, $a_{\text {., }}$-zito.

$\mathrm{He}$, she, pron., yeye.

Here, adv., hapa.

Hill, s., kilina.

Hippopotamus, s., kiboko.

Honej, s., asali ya myuki.

Huok, s. (tish), deama.

Horns, s., peinbe.

Hot, a., -a inotu; (of the suri), kali.

Hour, s., saa.

House, s., nyumba, chumba.

How ? interj., je? kwaje? How great? kubwa kama ipi? How much? kiasi gani? How inally? ngapi ?

Hunger, s., ujaa.

Hunter, s., mvinda, plur. w'andarobbo.

Hit, $\imath$., piga.

Hole, s., tundu.

Hide, s. (skin), ngozi.

Herd, s., kundi.

Hyæul, s., fisi.

\section{I.}

I. pron., mimi, ni-. I not, si-.

If, conj., kanla.

Ill. I am ill, siwezi. He is ill, hawezi

In, into, prep., katika, -ni.

In order that, eonj., illi.

In the middle of, prep., kătikati ya.

Indian-corn, $s_{\text {, }}$ sce Corn.
Ink. s., wino.

Insect, s., dudu (beetle).

Interpreter, s., mkulimani.

Iron, s. , chuma.

Itch, s. (skin disease), upele.

Ivory, s., horn.

J.

Journey, s., safari.

Jug, s., kopo.

K.

King, s., sultani.

Kite, s., see Hawl.

Kuife, s., kisu.

Knot, s., fundo.

Kudu, s., pouru.

L.

Lady s., bibi.

Lake, s. (a pool), ziwa.

Lead, s., sec Bullet.

Least, $a_{\cdot}$, - -dogo, -dogo sana.

Left, left hand, $a_{.},-$a kushoto

Leg, s., sec Foot.

Lernon, s., limao.

Leopard, s., chui.

Lesser kudu, s., kungu?

Letter, s., barua.

Liar, s., mwongo.

Light, s. (daylight), mchana.

Light, $a$. (not heavy), -epesi ; light a tire, washa motu.

Like, eonj., kama.

Lion, s., simba.

Little, a., -dugo.

Lizard, s., mjuzi.

Load, s., see Bundle.

Look! tesaina!

II.

Nagic, s., mchowi.

Maize, s., sce Corn.

Male, a. (man), ume ; (animal), ndune.

Man, s., inwana mume, mtu.

Mingo, s., mwembe ; (fruit), embe.

Mingrove, s., mkoko.

Many, a., -ingi, tete.

Narch, s., safari ; (forced march), teragezi.

Master, $s_{.}$, inbana.

Natter. What is the matter? kuma nin? It does not matter, haithurt.

Meal, s., sec Fond.

Medicine, s., dawa.

Message, \&., liabari.

Milk, s., maziwa.

Millet, s., sec Grain. 
Mind, $v$, angalia. I do not mind, luai thuru.

Ninute, s., dakika.

Miss, $v$. (shooting), epea.

Monday, s., Juma atâtu.

Mombasa, s., mvita.

Noney, s., fetha.

Monkey, s., inbega, plur. mbeghi.

Month, s., nwezi.

Muon, s., mwezi.

Morning, s., assububi.

Mpallah, s., swalah.

Mosquito, s., imbu.

Moth, s., noondu.

Mother, s., mama.

Much, adv., sana.

Mud, s., tope.

Music, ngoma.

My, mine, adv., -angu.

Measure (about nine feet), doté ; jora, Io doté; 6 jora, one load of cloth (65 lbs.).

\section{N.}

Nail, s., msomari.

Name, s., jina. What is your name? jina gani?

Natives, s., wazenzi, wanyika (bushmen).

Near, a., karibu.

Necklace, s., mkufu.

Need, v., taka. I need, nitaki. I do not need, sitaki.

Needle, s., sindano.

Net, s.: mshipi, jarifa.

Night, s., usiku.

No, interj., hakuna, hapana, la.

Nobody, s., si mtu.

Noose, s., tanzi.

Noon, s., jua littwani.

Nor, eonj., wala.

North, s., kaskazini.

Northern, $a$, -a kaskazini.

Nose, s., pua,

Not, adv, si ; (in verbs), si-, ha-.

Nothing, s., si kitu. I did nothing, si kufanya neno. I want nothing, sitaki kitu.

Now, adv., sasa; at once, sasa hivi.

Nut, s., kokwa.

O.

Observe, v., angelia, ona.

OF, prep., -a.

Oil, s., see Fat.

On. adr., mbele. Go on, endelea mbele. A little way on, inbele kidogo.
Onward, adv, sce Forward.

Open, v. (untie), fungua; (a door), sindua.

Orchilla weed, mereri.

Ornainent, s., painbo.

Ostrich, s., buni.

Our, a., -etu.

Out of the way! similla, similla mbele!

Go out! toka!

Oryx-beisa, s., mpouru (?) cheroa.

Ought, $\imath$. I ought, imenipasa. What ought we to do? tufanyaje?

Oven, s., tanuu.

Over, adv., juu.

Owl, s., bundi.

Own, (mine), angu mimi; (your), -ako wewe.

Ox, s., nghombe.

\section{P.}

Pail, s., sce Bucket.

Paint, s., see Dye.

Palm-tree, s., see Cocoa-nut, Date, \&c.

Palm-wine, s, tembo.

Paper, s., karatasi ; (document), khati.

Parrot, s., kasuku.

Path, s., njia ; (Arab), sikkah.

Peg, s., chango.

Pen, s., kalamu.

People, s., watu.

Perhaps, adv., labuda.

Palm branch, s., myali.

Person, s., mtu.

Pig, s., nguruwe.

Pigenn, s., njiwa.

Pine-apple, s., nanasi.

Pipe, s. (tobacco), kiko.

Pistol, s., bastola.

Pit, s., shimo.

Plantain, s., see Banana.

Plantation, s., sec Allotinent.

Plenty, s., tele, wingi.

Pocket, s., liifuko.

Poison, s., sumu.

Pole, s., mti ; (for punting), upondo.

Pomegranate, s., kamamanga.

Pool, s., see Lake.

Porcupine, s., nungu.

Porter, s. (caravan), mpagazi, plur. wapagazi.

Pot, s., sec Cooking-pot.

Potato, s., kiazi (sweet).

Pour, $v$. (out, away), mwaya.

Powcler, s., see Dust, Gunpowder.

Praise, s., sifa.

Present, s., ada, kalemba, zawadi. 
Presently, adr., halafu yake.

Pretty, $a$. , see Beautiful.

Promise, s., ahadi; break a promise, acha ahidi; keep a pronise, fikiliza ahili.

Promontory, s. (cape), rasi (Arabic).

Property, s., mali, milki.

Pull, v., vuta ; (dragr); kokota.

Punishment, s., athabu.

Put, v., tia; put on (clotles), vaa ; put off (cluthes), via ; put out, toa ; put to (shut), shindikil; put down (a load), tua.

Quantity, s., kadri.

Quarter, s., rubo.

Quick, a., -epesi. lie quick! upesi ! hima !

Quietly, adv., sec Gently.

(Quiver, s. (of arrows), podo.

Quarrelsome, a., -gonivi.

\section{R.}

Rabbit, $s_{.}$, stungura.

Race, s. (tribe), kalbila ; (of ruming), shindano.

Rain, s., mvua.

Rain, $\imath$, nya.

Rainy season, $\varepsilon_{\text {., masika. }}$

Rat, s., panya.

Rather (I had rather go), nitaka kwendit.

Red, $a_{\text {., }}$-ekundu.

Reed-buck, s., porké

Remote, $a$, see Far.

Reply, s., inajibu.

Reply, $\because$, jibu.

Require, $v$. (want), taka.

Return, v., sce Come back.

Rhinoceros, s., kifāru.

Rice, s. (clean), mchele, inpunga; (cooked), wali.

Rich, $a_{\text {., }}$-tajiri.

Ration, $s$. (measured portion), kababba.

Riglit, a., see Good. 'That is right, see Good! also vema; to the right, kulia.

Ring, s., pete.

Ripe, $a_{\text {. }}$, bivu.

River, s., into.

Roul, s., see Path.

Rock, s., mwamba.

lioom, s., sce Apartment.

Root, s., shina.

Rope, s., see Cord.

Rotten, a., -bovu.
Ronnd, adv. and prep., panda zote.

Rupee, s., rupia.

Rust, s., ukutu.

S.

Sack, s., gumia, also see Bag.

Safe, safely, safety, $a_{\text {, }}$, s., adr., salama.

Salie (for the sake of), kwa ajili ya.

Salt, s., chumvi; salt water, maji-achumvi.

Salutation, $s_{*}$, salaam, salama.

Same, a., see Alike.

Sand. s., inchanga.

Sandfly, s., usubi.

Saturday, s., Juma a mosi.

Saw, s., insumeno.

Say, $x$, sema.

Scrape, $v$, liuna.

Sea, s., bahari.

Seat, s., sec Chair. Take a seat, kaa kitakn.

See, $\imath$, ona, taz ana.

Send, $r$, peleka, leti.

Serpent, s., nyoka; (big), joka ; (python), chatu.

Set, $v$, tia; (on fire), tia motu.

Sew, $v_{\text {. }}$ shona.

Shame, s., haya.

Shark, s., papa.

Sharp, a., -kali.

Shed, s. (hut), banda, kibanda.

Sheep, s., kondoo.

Shield, s., ngrao.

Shoe, s., see Boot.

Shoot, $r$, piga.

Short, a., -fupi.

Shout, s., kelele.

Shout $r:$, piga, kelele.

Shut, v., funga ; (a door), pingia.

Sick. I an sick, siwezi. Are you sick? huwezi?

Side. On both sides, pande mbili : on all sides, pande zote; on the other side, nghaniuo.

Silence, s., kinya. Be silent, makclele, liyamaza.

Skilful, a., -hodari.

Skin, s., see Hide.

Slave, s., minuwa.

Slavery, s., utumwa.

Sleeping mat, s., mikeka.

Slow, $a_{*},-a$ mpole.

Sluwly, adr., see Gently.

Small, a., see Little.

Small-pox, s., ndui.

Smart, $\alpha .$, sic l)andly.

Sinoke, $s$, moŭi. 
Snake, s., sec Serpent.

Snare, s., nutego.

Soap, s., sabuni.

Soldier, s., asikari. askari.

Sometimes, adv., marra.

Sort, s. (kind), ginsi. What sort of ? gani?

South, s., linsini.

Speak, v., see Say. Speak loud, sema sana.

Spear, s., fumo, nkuke.

Spider, s., buibui.

Stick, s., fimbo.

Still, yet, adr., tena, bado.

Stomacl, s., sce Belly.

Stone, s., jiwe, plur. mawe ; (small), kokoto.

Stop, wait! $v$, ngojia.

Strong, $a$., see Skilful.

Stupid, a., see Fool.

Sugar, s., suliari.

Sugar-cane, s., inua, plur. miwa.

Sun, s. jua.

Sunday, s., Juma a pili.

Sunset, s., magaribi.

Sunrise, s., kucha, kwa jua.

Sweet, $a_{.},-$tanu.

Sweet potato, s., see Potato.

Sword, s., sime, upanga.

Steinbock, s. (gazelle), ishah.

\section{$\mathrm{T}$.}

Table, s., meza.

'Tail, s., mkia.

Take away, $v$, chukua, toa.

Take care, $v$., sce Care.

Talk, v., see Say.

Tall, long, \&c., c., - refu.

Ten, s., chai.

Telescope, s., durubini.

Tent, s., khema.

Thank you, asliante, marahaba.

That, how that, conj., kama; in order that, illi.

That, pron., ili, uli.

Then, $u d v$., sce Afterwards.

There, adv., huko; there is not, hapana, hakuna.

This, a., huya, huu, hiki, plur. hawa, hivi, hii.

They, pron., was; (with verbs), wa-, i-, vi-; they not, hawa-hai-havi.

Thick, $a_{.}$, -nene.

Thin, a., -embanba.

Thing, s., kitu.
Thirst, s., kiu ; be thirsty, $v$, ona kiu.

Thorn, s., mwiba.

Thoroughly, adv., sana, vema.

Thread, s., uzi.

Throat, s., koo.

Throw, v., tupa, tupia.

Thunder, s., radi.

Thursday, s., alhamisi.

Tie, $v$, see Fasten.

Time, s., wakati. What time is it? saa ngapi? Time after time, marra nyingi.

To, prep., kwa.

Tobacco, s., tumbako.

To-day, adve, leo.

Together, adv. and prep., pamoja.

Tooth, s., jino, plur. meno.

Tortoise, s., kobe.

Town, s., mji.

Track, s., see Path.

Trap, s., see Suare.

Travel, $v$, safiri.

Traveller, s., msafiri.

Tree, s., mti, nlur. niti.

Tribe, s., see Race. Of what tribe are you? mtu gani wee?

Tribute, s., see Black-mail.

True, $a .,-a$ kweli.

Truly, adv, yakini, kweli.

Tumble into, $v$, tumbukia.

Turban, s., kilemba.

Turtle, s., kassa.

Tusk, s., sce Horn.

\section{U.}

Ugly, a., - baya.

Uncover, $v$, funua.

Under, underncath, allv, and prep., see Below.

Understand, v., fahamu, tambua.

Undo, s., see Open.

Unripe, $a$, - bichi.

Until, conj., hatta.

Up, adv., sce Above.

Us, pron., sisi; (in verbs), tu-, -tul-.

V.

Valley, s., boonde.

Vegetables, s., mboga.

Venomons, a., -tnyi sunu.

Very, adv, sana.

Village, s., kijiji.

Voyagre, s., safari. 
IV.

Wages, s., mshahirat.

Wait, $v$, sec Stop. Wait a bit! ngoje kwanza!

Want, v., taka.

War'm, a., -a motu.

Wart-hog, s., see Boar.

Washerman, s, dobi.

Water, s., maji.

Way, s., see Path.

We, pron., sce Us. We not, hatu-.

Weapon, s., sce Aruns.

Wednesday, s., Juma a tano.

Week, s., juma.

Well, adv., vema sana. Well done! see Guod!

West, s., magaribi.

What? interog., nini; (in verbs), -ni? What is the matter? kunani?

What? pron., gani? -pi ? yupi?

What a fool ! mjinga kabisa!

When? interog., lini?

Whence have you come? umetoka wapi?

Where? wapi? -pi ?

Where are you going? wendapi? I do not know where $\mathrm{I}$ am going, sijui ninapokwenda.

White, $a_{\text {, }}$-eupe.

Who? interog, nani?

Who, rel., -ye, -o.

Whole, a., jia, -ote.

Wide, a., -pana.

IVife, s., nike.

Wild, a., mvitu.

Wildemess, s., sce Desert.

Wilde-beest, s, nyumbu.

Water-buck, s., kuru.

Wind, s., baridi, upepo.
Wipe, $r$, futa.

Wire, s., nzi wa chuma ; (iron, brass) uzi wa shaba.

With, prep., na.

Within, prep. and $a d v$, ndani ya.

IVithont, prep., pasipo ; (outside), nje.

Woman, s.. inwanamke.

Wonder, s., ajabu.

Wood, s., nuti ; (forest), mwitu, msitu.

Work, s., kazi.

Worm, s., chango, funga.

Worth. What is it worth? sec Cost.

Wound, s., jeraha.

Wound, v., piga jeraha, umiza. Be wounded, jeruhi.

Write, v., andika.

Writing, s., andiko ; (letter), barua.

\section{Y.}

Yam, s., see Potato.

Yard, $s$. (enclosure), ua, uwanda.

Year, s., inwaka; last year, mwaka jana; year before last, mwaka juzi.

$Y$ es, interj., nam, inshallah.

Yesterday, s., jana ; day before yesterday, juzi.

Yet, eonj., bado.

Yonder, adv., kule, pale.

You, pron., wewe, plur., ninyi ; (in verbs), sing. u-, -ku-, plur. m-, mw-, -wa-; you not, hu-, plur.ham, hamw-.

Your, a., -ako.

Young man, s., kijana.

\section{Z.}

Zanzibar, s., Unguja.

Zebra, s., pundantilia.

NUMERALS (Arabic and Swaheli, both in usc).

One
Two
Three
Four
Five
Six
Seven
Fight
Nine
Ten

One

Four

Five

Seven

Nine

Ten

Straheli.
noja
pili, mbili
tatu
'nne
tano
sita
saba
nane
kendia
kuni.

Arabic.

wahed.

etneerr.

telata.

arba.

khansa.

setta.

saba.

temania.

tessa.

ishiara. 
Eleven

Twelve

Thirteen

Fourteen

Fifteen

Sixteen

Seventeen

Fighteen

Nineteen

Twenty

Thirly

Forty

Fifty

Sixty

Seventy

Eighty

Ninety

Hundred

Thousand
Swaheli.

kumi na moja

humi na mbili

kumni ua tatu

kumi na 'mue

kumi na tano

sitashara

kumi na saba

kumi na nane

kuni na kenda

asharini

thelathini

arobaini

hamsini

settini

sabweni

themanini

tissaini

meah

elfu
Arabic.

hadashara.

etnashara.

telatashara.

arbatashara.

khamsatashara.

settashara.

sabatashara.

temantasbara.

tessatashara.

ashareen.

telateen.

arbaeen.

khainseen.

setteen.

sabaeen.

temaneen.

tesseen.

meab.

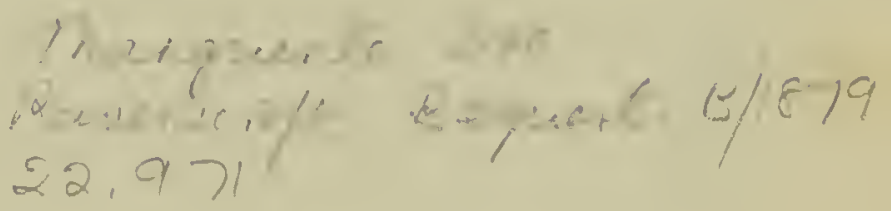


THE GAME OF BRITISH EAST AFRICA. By Capt C. H. Stigand, F.R.G.S., F.Z.S. It presents special fatures whioh will appeal to all true sportsmen, for it is no record of mere slaughter, but the impressions of a hunter who is at the same time an ardent field naturalist. The habits of wild animals are perhaps the most fascinating form of study, and the author has had exceptional opportunities of observing them, and knows how to record his experiences vividly. The many illustrations of spoor, \&c., add greatly to the attractive. ness of this important book. Second Edition. Demy 4to; profusely and beautifully illustrated. Price 21s. net.-FIELD \& QUEEN (HORACE COX) LTD., Windsor House, Bream's Buildings, London, E.C.-[ADVT.]

The Man-Eaters of Tsavo, and other East African Adventures. By Lieut.Colonel J. H. PatTerson, D.S.O. With a Foreword by Frejerick Covrteney Selous, and over roo Illustrations. 8vo. 7s. $6 d$. net.
62I PATTERSON (Lieut.. Col.J. H., author of "The Man-Eaters of Tsavo") In the Grip of the Nyika, Further Adventures in BRITISH EAST AFRICA, maps and over 100 illustrations. $8^{\circ}$, $4 s(7 s 6 d \mathrm{~N}$. 


\section{INDEX.}

ABARRI river, 238.

Abbott, Dr., 263.

Aecident, by burning, 87 ; seizmre by a lion, SS.

Alilm, a filsc, 70, 71, 138, 219.

Alligators, shot, 192; $248,250$.

Ancestors, worship of, 85, I I 8 , 75 .

Ant, a quite terrible, $25 \mathrm{I}$.

Antelope, a sable, 46, 47; a pretty little, 99 ; female, 99 ; oryx-beisil, 99, 163, 222.

Ant-heapss, 98, 99.

Anthem, National, of Ziluzibar, 15, 17.

Anole, my man, 40; ents a ligrure, $5 \mathrm{I}$; on the war-path, 70 ; sets fire to the dry meadow-grass, 72 ; punished, I6I ; incapable of pack: ing, 173 ; looks after himself, IS I ; in a bad way, 221 .

Arabs, 6, 15, 29, 32 .

Arcadia, a peaeeful, $S_{I}$; a nativc, I 80.

Ariangulu, camp at, $4 S$; 54 .

Armoury, our, 9 .

Aslie, Mr., 4.

Attendants, our personal, 40, 173 .

BABOONS, I 96.

Bait, human, 125.

Binana, the, the staple food, 63 .

Barani, river, 274, 276.

Battery, ollr, 4I.

Beads, in favour, $59, \dot{0} \$, \delta_{2}, \delta_{3}$; trade in, I74.
Bechive huts, So, 8I, I 20.

lices, manner of hiving, 65 ; attuck of, 268.

Belail, a wretehed Rabai man, S9, 90, I 7 I.

Bimls, Mrr., 37.

Bismarck thunlers terrilie threats. 20.

B'.ond-brothers, ecremony of making, $8_{5}$.

Boats, propellinier, on the Tiuna, 267.

Bohete, a heal man, 39 .

Boots, loss of our, $S_{7}$; reeovery of, 94 .

Bows and arrows, 59.

Boy, a mission, citcelises me, 37 .

loycotting, eommon in Africil, 272.

lirandy, Hamburg, 264.

liridges, primitive, 103 .

Buffilo, the African, 105, 189, 190; danger of hunting, 105, 106 ; my introductiou to, $13 S$; abundant, I $8_{3} ;$ my first, 189 ; a magnificent specimcu, IS9; all infuriatell, I9I ; a tough, 195; a capital ball, who charged us, shot deal, 20I; one killed by a single slot, $236 ; 238$.

Buffialo-birds, I 3 s.

Bullets, steel-tipped, I4I.

Bush-buck, an unwary, 194; the, 194.

Bush-laud, 5 I, 53, 6I.

CAČECHE, a wily nigger, 38,39 ; makes a stirring speceh, 56,$57 ; 62$; as 
proxy, $S_{5}$; eomes to my resene, 91, 93; 159; gets us into trouble, I $S_{7}$; eaught out, 252.

Caeti, the, ro.

Cuga, the, country, 20 ; tribes, $S_{3}$, I 10; track, 92, 103 ; people, 94.

Cala, Lake, 91, 165, 166, 227.

Camp, our first, 36 ; arrangements, 41, 42; at 'laveta, 77 ; the Lion o1 Simba, I39, I64; a river, 159 ; 177 ; an old Misai, 247.

Caravan, our, $3 S-4 I$; a, of slaves sighted by $n s, 69$; tired on, $7 \mathrm{r}$.

Casibete, a friend in need, 91,93 .

Cattle kept in huts, 160.

Ceremonies, the Snltan's, master of, I6.

Ceremony, a disgnstingr, 94.

Chains, ormamental, 59 ; manufacture of, I 6 , i 17 .

Champagne, a piek-me-np, 52.

Chandi, 50, $87,94$.

Charge, a, 155 .

Charra, 267.

Chase, a will-goose, 96, 2 I6.

Children, $s_{3}, 8_{4}$.

Christmas, kept, 73 .

Chungnani, I I, 1 2, 17.

Civilisition by conversion, 23 .

Coin in nse, $S_{3}$.

Colonisation, German, 259.

Comforts, our medieal, 4 I.

Commor, eimul at, 27\%.

Country, a lark-like, 22 I.

DAYCE, a native, $211,212$.

Dances, topical, $8 S$; interdicted, $S S$, 89.

Denhardt, the brothers, 264 .

Déra, 27 I.

Deserters, one of, caught, 43; 011. treatment of, $46,49,50-53 ; 63$. $86, S_{7}$.

Desertion, 43,44 .

Dhow eatching, $2 \mathrm{r}$.

Dinner, al, and a bee-swarm, 26: a sportsman's, 1.34 .

Diseovery, a terrible, 50.
Diseretion, the better part of valour 165.

Distanee, native ideas of, 96 .

Donkey's, our, 40 ; one in trouble, $\mathrm{I}_{3}$.

Doruma, the $47,48,58$.

Dress, our, 41.;

Drive lome, a, I4.

Drummond, Mr., Ir, I4; his lospitality, 27.

Drunkenuess among the Swahili, 1 36,137 .

Duiker, a, 263 .

Durani, 273.

During, Mr., 266, 267.

Edr-Rivgs, wearing of, 6S, Si.

Eirthquake, an, 242.

Iiel, a gignantic, 194.!

Fland, my first, I29; the, I30, 239; two shot, 239.

Elephant, tracks, 175, 220 ; her in sight, 23I; heard at himd, 232; my first, 233; an, cow bronght down, 234 .

Elephant-hunter, a Swalili, 101.

Emin Pasha, I75.

Engrinecring among the Kiboso, I 3, 214.

Esa-Moussa, our interpreter, 210: 215.

Escape, a lneky, I6r.

Fiss, my grun-lyearer, gets drunk, but repents, 135, 136; my narrow eseape of being shot by, 162 ; deelines my offer to purehase lis freedom, 259.

Farmi, Mr., 30.

Feast, a, provided by the Sultam, I 3, I 4 .

Fever, attaclis of, I 54, I55, IS6, I9I ; a novel enre for, 235.

Field, a new, 2.

Fights among:t the men, ro2.

Fishing in the Lumi, 90, 91 ; in Lake Jipé, I 34 .

Fiteh, $\mathrm{NI}$ 1., I04; aecount of, 109 ; I10, II I ; at houre, I25, I 26 ; his curiosities, 126.

Flies, abundant, 196. 
Forest, a magnificent, 216.

Freretown, 29, 30, 264 .

Gallas, tlie, their persons and nimners, $268,269,270,273$.

Game, abundanee of, $69,73,147,177$; try for bier, 74 ; paths, 74 .

Game eountry, the big, 69 ; a perfeet, 150.

Game-pit, undignified position in a, 9I; donkey enught in a, I63.

Gazella Thomsoni, 262.

Gazella Walleri, the, 245, 273, 274.

Gazelle, the miniature, I0, 49, 51, 74, IO2.

Germans, distrust of the, 19, 20 ; met none, 20 ; outwitted, $20,110$.

Giraffe, the, 77, 97, 102 ; I 8 I.

Goat, a, for dimmer, 28.

Golbanti, mission-liouse at, $267 ; 272$, 282.

Granti, the, 99 ; a splendid speeimen of, 140; plentiful, $245,246$.

Grave islaud, 9, 10.

Greenfield, 262, 265, 270, 271, 273, $274,276,279$; returns with all elephant's tail, 2 So; low he did for the elephint, 280 .

Guinea-fowl, the vulturine, 25S, 270.

Gun aeeidents, I 50, I 62, 233.

Gun-bearer, lieked for his gallantry, 203.

Giinther, Dr., 275 .

HAGGARD, Mr. Riller, 125.

Hanningrtou, Bishop, 4.

Harris, a greologieal Mrs., 223.

Hartebeest, the, 54,55 ; a muisinee, 98 .

Harvey, Sir'R., sugrgests and arrauges for the expedition, I, 2 ; oblig:ttions to, 3 ; bags a crazelle, $10 ; 27$; makes in present to the grovernor of MIombasa, 3 I ; 35 ; sees elephants' traeks, 55; shoots a fine giralle, 77 ; groes ofl to lunt with $\mathrm{Mr}$. Jackison, 79; starts to shoot at Rhombu, 9I ; his sport, I3I, 163; tlie big master, I73; lias great esenpes, 178, 191; kills a lioness about to spring on lim, I99; is attacked by a buffilo, 202; goes to Rlombu, 242; lis return, 253 ; starts for Kalé, 254; is brought baek by sad news from lome, 254 ; lis letter, $262-282$.

Harvey, C. B., 2 ; expeeted, 78, 79 ; joins us at Rliombu, I3I ; lis sporting suceesses, I3I, I43, I63; his birth-dily, I37; the little master, 173 ; shoots a lion, 192.

Henry Wright, the steamer, I7.

Highliunds, Seottish, seenery like the, 62 .

Hindus, in Zanzibar, 259.

Hippopotani, sport anong the, 249, 250 ; four killesl, 250.

Holmwood, Mr., 6, 7, I I, I4, I 7, 24.

Hönel, Mr., $24 \mathrm{I}$.

Hongo, 64; eeremony of, $8_{4}$; Swaliti, 84 ; demand of, 153 .

Horn, a lieavy, 263.

Horneehe, Mr., his eourtesy, 19, 20.

Houghton, Mr. and Mrs., murder of, 267.

Hunter, II. C. V., 2, 27, 55, 6I ; onr gardener, 87 ; shoots a bufialo bu1l, 105, 106; his sport, 163; the fat master, I73; shoots a magnifieent bullalo, I 33 ; laid down witl fever, 229 ; groes to Rlombu, 242; lis return, 253; bound for Kahé, 254 ; $262,268,270,271,273,274,276$, 277,279 .

Hunteri, a new speeies of antelope, deseribed, $275,276,277$.

Hyxena, the, I44, I 7 .

IMAN of Museat, the, 9 .

Ineident, an unfurtunate, I 50.

Inscets, a great annoyanee, $25 \mathrm{I}$.

Interpreter, the Sultan's, 16.

Iron, said to be abundant in the Pari nountains, 74 .

JACKS()N, Mr., 74 ; lis bag of gaue, 74 ; proposes a slooting trip, 7S; 
his insect eolleetion, 90 ; at Rhomlu, 91; 131, 132, I39; I eompare notes with, 197; his remonstrance, 199,$200 ; 235,240,254$.

Jipé, Lake, $64,74,79,90,98,131,132$, 133 ; fishing in, 134 ; game at, $242-$ 244 ; gool sport liere, 24 S.

John, the headuin, 40, 173.

Johuston, Mr., at fault, 90, 95, 99, 122.

Jomvin, 36.

Jones, Mr., an obliging black missionary, $3 S, 4 j$.

Jovia, 62 ; the traek to, 256 ; reitehed. 257.

Jumba Kimameta, 149.

Jumura-Orioladi, 39.

KAHÉ, path, So; people, 94 ; the forest of, 106, 121, 179.

Kalepi Creek, 264.

Kasibete, 39.

Kienia, Mount, 264.

Kibo, 70, 72, 121, 148, 160, 223, 224; deseribed, 225, 226; reported aseent of by Germans, 226, 227 (note).

Kiboko, 74; mearly throttlesa boy, 103.

Kiboko, the $\log , 266$.

Libonn, 64 .

Kiboso Distriet, 217.

Kiboso, the, I13, I14, 1SI, 182, 205 ; their langriage, 215 ; laclies, 218.

Kiěaga, I0I, $215,219$.

Kikavo, river, I86, 204, 229.

Kilima-njaro, 1, 2 ; sigrlated, 70 ; good view of its grandenr, $72 ; 79$; on the slopes of, 91, 104, 121, 140, 148, 165, 219; aseent of, 223 ; our experienees on, 224, 228, 229.

liilina Mombasa hill, 234.

Kima, 225.

Kinnawenzi, $70,72,148,223,224$; deseribed, 225, 226.

Kimengelia, 146, 148, 159.

liings by divine rigrht, I I 2.

Kirk, Sir Joln, 6; letter fronı, I6 ; his villa, 24 ; esteem he is held in, 25,122 .
Ǩisigrañ, MIt., 56 .

Kitembo, Master, 103.

litimberiu, 125.

lioso, the eliief of, 271 .

lisavo, the, 148 .

lindu, the lesser, 100.

\section{I.AMU, 2, 4.}

I anjora, little, 73 ; patl, 80 ; hig, 73 , $94,96,97$; the soil near, 98 ; 135 .

Jawu-tenuis in Zintuibar, 8, 25.

Leopard, a, trapped, 171.

Letter of Sultan unappreciatel, $4 \mathrm{~S}$; 67.

I,ewali, the, of Mombasa, $28,32,265$. lion, sittiug up for, IOI ; my first, 198 .

Lioness, a, in sight, 46, 199.

Lions, 32, 46; growling round our eamp, 98 ; two sighted, I33; forr fired at withont efleet, I3t; himmless in these pirts, 139.

Lioll-traps, 124, 125.

Jizard, a very large, 278 .

I.oads, our, 40.

Joeusts, jink-eolonren, 44.

Lost in the jungle, 93 .

"Love, free," 119.

Luek, a pieee of, 200.

Lulu, the gymmast, 30 .

Lumi, the river, 90; fishing in, 90, $91 ; 104,139,171$.

Lineh, a slight, 14.

Mabrouki, the brigand, lying in wait, 255.

Magri-a-ehumvi, 45 .

Mallalulu, Little, camp at, 27 S Big, 279.

Mahoned, Ali, 263.

Mahommedin women, expense of convertings, 26 .

Malindi, 265.

Miundara, $30,50,69, S_{5}, 94$; semds a letter to Mirtin, 104; messenfrers from, IO4; enter his dominions, I06; a messagre from, IoS; his abode, IOS; the greatest bully of these parts, IoS; the honour he 
shows us, Iro; gives us andience, I IO; is jealous of Sina, I10; threateus Martin, Iro; personal appearance, dress, and manncr, II I ; under pombé, i I ; low regarled, II 2 ; secret of his power, II 2 ; a first-class diplomat, I12; extent of his lonle, I 13 ; surprised ly a Kiloso raiding party, II3; his iron hut, II 3 h his wives, II4; mode of punishment, I 14 ; his vietinus, I 15 ; his conceit, II 5 ; his subjects, I I 5 ; a clever armourer, II6; a soothsalyer, IIg; mauner on receipt of prescits, I22, I23; slirewduess, I22; opinions, I22; dcclines to be photographed, I22; visits onr camp, 123; and the photographic art, I24; plain-spolicn, r24; receives a lion-tiap, 125 ; his wicked nse of it, I25; his present of a milch cow, I25; farewell to, 127 ; my satisfaction at havingr seen him, I27; his position no sinecure, ISI. Marriage ceremonies, curions, IIg.

Martin, 2 ; arranges matters, 8,9 ; 31 , 35,38 ; account of, 38,$40 ; 49,50$, 53, 65, 66, 67; makes a mistalie, 73 ; ground belon!ning to, 77 ; refuses hongo demanded, $8_{4}$; a blood-brother, $\delta_{5}$; in agitation, I07; his lıonse oeenpied by strangers, I07 ; imprisoned by the Useri chief, but escapes by a ruse, I48; realy wit of, 154; his comnsel talken, I84; villue of his serviees to us, 258; 262, 27l, 272, 274, 277, 279.

Masai, the, I, 2, 4, 38, 73, 8o, 8I ; il, war-party, 93 ; on the war patl, $137,148,153$; the railing, I60, 170; a burbear to us, IS4; abuse the W'Arusha, 210 ; physiognomy, 210; a few, visit us and request liongo, 247; troublesonc, 262 ; wealth in cattle, $262 ; 268,269$.

Natate, 64 .

Matrimony, peliminaries to, ir 8.

Matthews, Gen., 7 ; regnlau's under,
I5; forcstalls the Germans, 20,24 ; our leave of, $27 ; 35,110,148$.

Man̄nğแ. 51-53, 54, 63, 255.

Mbogoli, 64 ; his headman, 65 ; his warriors, 66,68 ; lis approach, 66 ; deseribel, 66 ; lis pime minister, 66,$67 ;$ presents, 67 ; lis right eas, 68 ; retires when he can get nothingr from ns, 68 .

Mbweni, 24.

Membril, and eountry beyond, 265.

Mcn, onr, 24, 38, 39, 40. 42 ; onr, and the rifles, 43 : a lit soft, $46 ; 52$; relieve their feclinuss. 57 ; mutiuy among, ISo; their Arcaclia, ISo; grumbling, 237.

Mercreni, 265 .

Meru, Mt., Iо6, IоS, I13, 126, I48, $243,262$.

Milk, I 20.

Miriale, I I $3,254$.

Missionaries, in Zanzibar, their clicef occupation, 25 ; how manufactured, $26 ; 172$.

Mission men, difficulty about hiringr, 33; worthlessiess of, 39:40;63,71, 86; a typical specimen of one, 126 , $127 ; 172$; Rabai, 257,258.

Mission-stition at Mllweni, 25.

Nllinyn, 256.

Mlıとi. ₹o, 50, 94. I03: the nat nualised natives of otlier tribes ill, II4; the. II5; their dress and wcapons, I 6 ; their wounen, I 7 ; conutry of, I 20 ; climate of, I2I. See $W_{A-M O C I}$ Mourbasa, I, 2, 9 ; the bislop of, $1 \%$ 28, 29, 172 ; alrival at, 28 ; goveruor of, 28,32 ; vicc-consul's lionse in! 30 ; the town, $30-32 ; 25^{\text {S. }}$

Moment, an anxions, 154.

Monliey, roast, 136 .

Monkeys, shot, r35; black and white Cololins, I75.

Mosquitos, very lial, 267.

Momutaineering, enomert of, 228 . Mpallah, a herd of, 75 ; the, I 32 . Mto-abarri, the, 104, I 27, 256. 
Mug, a musieal, 66.

Mr-komeni, 255.

Munda, the island of, 4 .

Nanks, curions, 24.

Nittives, 45 ; pass us at full-trot, 65 ; and bee-hiving, 65 ; their idcas of distimees, 96.

Ndara, 53, 54, 55; scenery from, 56,59 ; the population of, 60.

Ngrai, 72.

Negatiumi, 27 I.

OMari, a useful fellow, 39 .

Oryx, a comple of, secured, 246. Sce A NTELOPL:

Ostrich, the, I76, 177 .

Ostrielıes, featlyers as ormanents, 68 , 73,82 ; only five killed, 176

Pangani, ronte, 9, i9; path, So.

l'arker, Bishop, 26.

Pari mountrins, 74, 79, 106, 177.

Parsees, in 'anzibar', 259.

Party, onr, 2.

l'elican Lake, 270.

l'emba, 21 .

Pest, a loeil, 242.

Plotographing natives, $48,64,123$, 158 .

J'igreons, grreen, 127.

Pira, the Sultin's factotum, I2, I3.

Pumbé, 88, ıog.

Porter., Zanzibari, 8 ; otr", 24, 33, 42 ; squabble over a giraffe's carcass, 78; Swaltili, 169; untiny among, 187.

P'restun, an alditional help, 39, 173

P'rogramume, our, 3.

Pnnishment, a brutal mode of, 237.

P'urehasiugs, our, 62, 63 .

\section{QUAILS, 57.}

li.ABAI, 29 ; start for, 33,35 ; arrival at, 36 ; a mission station, 36,37 ; the conntry near, 35 .

liaft, a, eonstructed, $24 \mathrm{~S}$.

Kain, very local, 52.
Rittles, worn on ankles, $\varsigma_{3}, 8 s$, I 16 .

liavens, white, 127 .

Reiorters, local, 28.

lihinoceros, a tough beast, 94 ; an inquisitive, 98; my first, I28, I29; the, its speed, 130, 131; steaks, 131; an cuormons, a grand prize. I40, 141 ; a, lhorn, I43; removing the horn of, I44, I 45; two done for, 146, I47; oue knocked over by another, a curious sirnht, 153; skull of, picked clean, I54; cow and lull, I55; a, trieornis, I55; the black bicornis, I66, 167 ; attiaclion by a lion, 201.

Plinoceros-birds, 129.

Rhino lrive, a. 157.

Rifle, theft of a, I6o.

Rhoubn, 9 I.

Roalf, Germau consul, 20, 2 I.

liontes, the, 9.

SADALLA, 267.

Salt, an apology for, 179 .

Siltpaus, Inatural, 265.

Samburn reaclich, 47 .

Silyyid Barganli, 18.

Seares, I85, 240.

Sccretary-lind, the, 143 .

Selous', IIr., book, 48 , Io6.

Shark, miraculous escape from a, $A, 5$.

Shaw, Mr., 29, 30 ; protest from, 33 ; bid him adieu, 35 .

Sheets, wateryroof, 60.

Shells, beautiful, 10.

"Short Street," in, I 78.

Siafu, the, 25I.

Sina, 85 ; Manclara's jealousy of, $10_{4}$ : rival of Mandara, 113; ntessagre frou, I74; a despot, I So; belıuviour towards us, I\$2; jealousy of Manlara, I82; his men routed by at buflialo, 193; visit to, 206 ; lis welcome to us, 207 ; his personal alpearance and tress, 208; his attendauts, 20S, 209; his eourtesy; 209 ; gives us frequent andiences, 2 II; a jowerful chief, 212 ; lik 
bodyguard, 212 ; our presents to, 212, 213; his fortres: 213 ; a good engineer, 214; gift from, 215; would be friends with the Masai, 217 ; distrusts the W'Arusha, 217; his son, a chief, would be brother witl us, 218,228 ; return to, $22 S$; photographed, 229; farewell to, 229.

Slavery rooted in Zanzibar, 22 ; properly supervised no hardship, 23; abolishable only at the root, 24 .

Slaves, cruelty to, 21 ; llumerous in Zanzilar, 227.

Slave trade, the, 22, 23; no wish to interfere with, 7 I.

Snake-bite, a, effeet of, 276.

Snuff-boxes and snuti; 59, 82, I 26 ; snuff, 279.

Sogronoi inomintains, 106, 121, 187.

Somalis, the, 26S, 269, 270, 275, 279.

Soudanese, the, as porters, 42 .

Speirs among the Wa-moci, i 16 .

Sport, a good, 28.

Stimpede, a, 73 .

Stanley, 175 .

Star, the steamer, and its captain, 27.

Start, our, 3 ; for interior, 35.

Steere, Bishop, 25.

Steinboek, a sulall, 74 .

Stools, eurious, 59.

Stork, a, shot, is 3 .

Stork, commotion about the, 265 .

Subaki, I48.

Sunday, a holiday, 170.

Superstitions, native, $64,118,119$.

Suleiman, a heachuan, 39.

Sultan, the, of Zanzibar, his palacc, 6 , I I, I2 ; his harem, I2 ; his tastes, 13 ; 15, 24; andicnee of, 14-17; offers a steamer, 17 ; aecount of, 17 .

Swalilili, the, 88 ; a, porter, 106 ; the, I34; the, porter, 169 ; a, caratvan attaeked and spoilcd, i 70.

TANA, river, 100; expedition to, $264 ; 271$; the country up, 272, 273 .
Taro, 4 S.

'Tavetil, forcst of, 1,3 ; roid to, 44 ; 74; our caravan arrives at, and enters, 75 ; its situation, 77 ; its extent and fertility, 79 ; its outer fringe, 80 ; a peaceful Arcadia, 81 ; a gily Babylon, 88 ; our house at, 102; return to, I28; 129, 132, I69, 239. See IVA-TAVETA.

Teita, 53 .

Teleki, Count, 3, 35, I49; arrives at Taveta, 241; his opinion of the Misai, 24I; his plans, 242, 243 ; left for Miriale, $25+$; 255 .

Tents, our, 4I ; a necessity, 42 .

Tsetse-fly, the, 196.

'Thigh, a broken, 242 .

Thomsoll, J., 2 ; his book, $3,38,48$, $53,77,106,122$.

Three Brothers, the mountain group called, 64.

Tobaeeo in 'Taveta, 79 .

"Toddy," 32.

Turquoise, the, $2 \mathrm{I}$.

Twins, 20.

UGANDA, 4.

Ughono, the, 64, 74; mountains, 79, 121 ; the, 115,134 .

Ukambani, 262.

Useri, patlı, 80, 91 ; river, 148 ; the chief of, 148, 149, 152, 159; the, thcir shyness towards us, I49; treachery towards, I49, 150; welconle by, I5I; the men and the women of, 152 ; $155,156$.

Useri, the, 149, I 5 I.

VIEw, a glorious, 165 .

WA-BONI, the, 268.

Wa-eini, the Arusha, 195.

IVa-juu, the Arusha, 195.

Wi-kahé, the, 174, 175, 178; wonnen, I79; and Mandara, I79; tacticians rather than winriors, ISo; said to he now exterminated, ISo.

Wakelield, Mr., 4, 36 . 
Wa-kiboso, the, I13, I74, 205, 213 ; their main village, $213 ; 217$.

Wa-kopomo, the, 267-270, 273 .

Walcs, Prince of, letter from, I4, I6.

Wa-mileanc, tlie, I I3, I I 4.

Wa-1llarimu, the, 113 .

Wami, the, Ioo.

Wa-moči, the, I15-II\&; crime anong, II 8 ; marriage among; 11 ; superstitions amoung, II9; other habits, I 20.

W'andarobbu, the, is6.

Wanyika, the, 45

Wrar-ery, I 20, 219.

Wa-rhombu, the, 140, 144, 165.

Wart-hog, the, 238,278 .

W'Arusha, the, 108 , II2, II 2, II4, I $85,195,204,205,210$; their Inallners offensive, 229 .

IIasania, the, 268, 273 .

Wa-tavetil, the, 79 ; their security and dwelling, 80 ; described, $S_{1}$, $S_{2}$; their women, $S_{2}, S_{3}$; their nnanners and customs, $S_{4}$; religion, 85 , 86 ; lionesty, 86 ; hold at howling, 93 ; disconfited, 170,171 , 240,252 ; alien to, 254 .
Wi-teita, the, 56, 58, 59, 70, 74 .

Water, want of, 50,52 .

Water-buck, the, I33; skull stolen by it hyona, I37; a good shot, I3S.

Weri-weri, the, I8I, I 82, 204.

Whiskey, in demind, 127.

Whistling, a signial, 2 I 8 .

Wife-beating, II 7

Wildebeest, a, bull which I shot, I 42 ; the, its appearance standing and ruming, a contrast, I43; I96.

Women, native, 63, 69; pregnant, $8_{3}, 152,179,216,217,213$.

Woodward, Cart, 2 I.

Wray, Mr., 56-5S, 6o; his residence, 257.

ZaxziBAR, 2, 5 ; the town and its buildings, 6,9 .

Zunzibaris, the, 9, 22; our, 33, 30.

Zebra, the, a nuisance, $93,9 \mathrm{~S}$.

Ziwa, the, I39, 143, 229.

Ziwa Matate, rusli to, 50, 54.

Ziwani, 49, 52, 255.

Ziwa-mazungrl, 255. 


\section{Eafalogue of Z̧ooks}

\section{MESSRS. LONGMANS, GREEN, \& CO.}

Abbey and Overton.-THE ENGLISH CHURCH IN THE EIGHTEENTH CENTURY. By CHARLES J. ABBEY and JOHN H. OVERTON. Cr. Svo. $7 s .6 d$.

Abbott.-WORK'S BY T. K. ABвOTT. THE ELEMENTS OF LOGIC. I 2 mo. 3 s. ELEMENTARY THEORYOFTHE TIDES: the Fundamental Theories demonstrated without Mathematics. Crown 8vo. 2s.

Acton. - MODERN COOKERY FOR PRIVATE FAMILIES. By ELIZA Acton. With 150 Woodcuts. Fep, 8vo. 4s. 6d.

Adams.-PUBLIC DEBTS : an Essay on the Science of Finance. By HENRY C. Adams, Ph.D. Svo. I2s. $6 d$.

A. K. H. B.-THE ESSAYS AND CONTRIBUTTONS OF A. K. H. B. Cr. 8 vo. Aut umn Holidays of a Country Parson, $3 s .6 d$. Changed Aspects of Unchanged Truths, 3s. 6 .

Commonplace Philosopher, $3 s .6 d$.

Counsel and Comfort from a City Pulpit, 3s. $6 d$.

Critical Essays of a Country Parson, $3 s .6 d$.

East Coast Days and Memories. 3s. $6 d$.

Graver Thoughts of a Country Parson. Three Series, $3 s$. 6d. each.

Landscapes, Churches, and Moralities, $3 s, 6 d$.

Leisure Hours in Town, $3^{s}$. $6 d$.

Lessons of Middle Age, 3s. $6 d$.

Our Little Life. Two Series, 35 . $6 d$. each.

Our Homely Comedy and Tragedy, $3 s$. $6 d$.

Present Day Thoughts, 3s. $6 d$.

Recreations of a Country Parson. Three Series, $3 s$. $6 d$. each.

Seaside Musings, $3 s$. $6 d$.

Sunday Afternoons in the Parish Church of a Scottish University City, $35.6 d$.

'To Meet the Day' through the Christian Year: being a Text of Scripture, with an Original Meditation and a Short Selection in Verse for Every Day, 4s. $6 d$.

Allen. - FORCE AND ENERGY : a Theory of Dynamics. ByGRANT ALLEN. 8 vo. $7 s .6 d$.

Amos.-A PRIMER OF THE ENGLISH CONSTITUTION AND GOVERNMENT. BY SHELDON AMOS. Crown 8vo. 6s.

Anstey.-THE BLACK POODLE, and other Stories. By F. ANSTEY, Author of 'Vice Versâ.' Cr.8vo. 2s. bds.; 2s.6d. cl.
Archer.-MASKS OR FACES? A Study in the Psychology of Acting. By William Archer. Crown 8vo. 6s. 6d.

Aristotle.-THE WORKS OF.

THE POLITICS, G. Bekker's Greek Text of Books I. III. IV. (VII.) with an English Translation by W. E. BollAND, M. A. ; and short Introductory Essays by A. LANG, M.A. Crown 8vo. 7s. $6 d$.

ThE POLITICs : Introductory Essays. By ANDREw LANG. (From Bolland and Lang's 'Politics.') Crown 8vo. 2s. 6d.

THE ETHICS; Greek Text, illustrated with Essays and Notes. By Sir AlexANDER GRANT, Bart. M.A. LL.D. 2 vols. 8vo. $32 s$.

THE NICOMACHEAN ETHICS, Newly Translated into English. By ROBERT Williams, Barrister-at-Law. Crown 8vo. 7 s. $6 d$.

Armstrong.-WORKS BY GEORGE FRANCIS ARMSTRONG, M.A.

POEMS: Lyrical and Dramatic. Fcp. Svo. 6s.

KING SAOL. (The Tragedy of Israel, Part I.) Fcp. 8vo. 5s.

KING DAVID. (The Tragedy of Israel, Part II.) Fcp. 8vo. $6 s$.

KING Solomon. (The Tragedy of Israel, Part III.) Fcp. 8vo. 6s.

UGONE: A Tragedy. Fcp. 8vo. 6s.

A GARLAND FROM GREECE; Poems. Fcp. 8vo. 9s.

STORIES OF WICKLOW; Poems. Fcp. 8vo. 9 s.

VICTORIA REGINA ET IMPERATRIX: a Jubilee Song from Ireland, 1887.4 to. 25. $6 d$. cloth gilt.

MEPIIISTOPHELES IN BROADCLOTH : a Satire. Fcp. 8vo. 4 s.

THE LIFE AND LETTERS OF E DMOND F. ARMSTRONG. Fcp. 8vo. 7s. $6 d$.

Armstrong.-WORKS BY EDMUND 7. ARMSTRONG.

POETICAL WORKS. Fcp. 8vo. 5 s. ESSAYS AND SKETCHES. FCp. 8vo. 5 s. 
Arnold. - WORKS BY THOMAS ARNOLD, D.D. Late Head-master of Rugby School.

INTRODUCTORY LECTURES ON MODERN HISTORY, delivered in I84I and I842. 8vo. 7s. $6 d$.

SERMONS PREACHED MOSTLY IN THE CHAPEL OF RUGBY SCHOOL, 6 vols. crown Svo. 3os, or separately, 5s. each. MISCELLANEOUS WORKS. 8vo. 7s. 6d.

Arnold.-A MANUAL OF ENGLISH LITERATURE, Historical and Critical. By Thomas ArNold, M.A. Cr. 8vo. 7s. 6d.

Arnott.-THE ELEMENTS OF PHYsICS OR NATURAL PHILOSOPHy. By Neil Arnott, M.D. Edited by A. Bain, LL.D. and A. S. TAYLOR, M.D. F.R.S. Woodcuts. Crown 8vo. I2s. 6d.

Ashby: - Notes ON PHYSIOLOGY FOR THE USE OF STUIDENTS PREPARING FOR EXAMINATION. With 120 Woodcuts. By Henry Ashby, M.D. Fcp. 8vo. 5 s.

Ashby and Wright.-THEDISEASES OF CHILDREN, MEDICAL AND SURGICAL. By Henry Ashby, M.D. and Geo. A. WRIGHT, B.A. F.R.C.S. 8vo. $21 s$.

Atelier (The) du Lys; or, an Art Student in the Reign of Terror. By the Author of 'Mademoiselle Mori.' Crown 8vo. 2s. $6 d$.

Bacon.-THE WORKS AND LIFE OF. COMPLETE WORKS. Edited by R. L. Ellis, J. SPedding, and D. D. HEATH. 7 vols. 8 vo. $£ 3$. I3s. $6 d$.

LETTERS AND LIFE, INCLUDING ALL HIS OCCASIONAL WORKS. Edited by J. SpEDDING. 7 vols. 8vo. E4. 4 s.

THE ESSAYS; with Annotations. By Richard Whately, D.D., 8vo, IOs. 6d.

THE ESSAYS; with Introduction, Notes, and Index. By E. A. AввотT, D.D. 2 vols. fcp. 8 vo. price $6 s$. Text and Index only, without Intraduction and Notes, in I vol. fcp. 8 vo. $2 s .6 d$.

Bagehot. - WORKS BY WALTER BAGEHOT.

BIOGRAPHICAL STUDIES. 8vo. izs. ECoNomic Studies. 8vo, ios. 6d. LITERARY STUDIES. 2 vols. 8 vo. 28 s. The Postulates of English PoLITICAL ECONOMY. Crown 8vo. 2s. 6d.

A Practical PLAN for AssimiLATING THE ENGLISH AND AMERICAN MONEY AS A STEP TOWARDS A UNIVER. SAL MONEY. Crown 8vo, 2s. 6 d.
The BADMINTON LIBRARY, edited by the DUKE OF BEAUFORT, K.G., assisted by ALFRED E. T. WATSON

Hunting. By the DUKE OF BEAUFORT, K.G. and MOWBRAY MORRIS. With 53 Illustrations by J. Sturgess, J. Charlton, and Agnes M. Biddulpli. Crown 8vo. Ios. $6 d$.

Fishing. By H. CholmondeleyPennell.

Vol. I. Salmon, Trout, and Grayling. With 150 Illustrations. Cr. 8vo. Ios. 6d.

Vol. II. Pike and other Coarse Fish. With 58 Illustrations. Cr. Svo. Ios. $6 d$.

Racing and Steeplechasing. By the EARL OF SUFFOLIK AND BERKSIIIRE, W. G. Craven, \&c. IVith 56 Illustrations by J. Sturgess. Cr. 8vo. Ios. $6 d$.

Shooting. By Lord IVALSINGHAM and Sir Ralph Payne-Gallivey, Bart. With 2 I full-page Illustrations and I 49 Woodcuts by A. J. Stuart-IVortley, C. Whymper, J. G. Millais, \&c.

Vol. I. Field and Covert. Cr. 8vo, Ios. 6d. Vol. II. Moor and Marsh. Cr. Svo. 1os. $6 d$.

Cycling. By Viscount Bury, K.C.M.G. and G. LaCY Hillier. With 19 Plates and 6I Woodcuts by Viscount Bury and Joseph Pennell. Cr. Svo. Ios. $6 d$.

Athletics and Football. By Montague SHearman. With 6 fullpage Illustrations and 45 Woodcuts by Stanley Berkeley, and from Photographs by G. Mitchell. Cr. Svo. Ios. $6 d$.

Boating. By IV. B. Woodgate. With ro full-page Illustrations and 39 Woodcuts in the Text. Cr. "Svo. Ios. 6\%.

Cricket. By A. G. Steel and the Hon. R. If. Lyttelton. With I f fullpage Illustrations and 52 Woodcuts in the Text, by Lucien Davis. Cr. 8vo. Ios. $6 d$.

Driving. By the Duke or BeauFORT. With Illustrations by J. Sturgess and G. D. Giles. Crown Svo. 10s. 6d.

Fencing, Boxing, and Wrestling. By Walter H. Pollock, F. C. Grove, C. Prevost, E. B. Michell, and Walter Armstrong. Cr. Svo. IOs. 6d.

Golf. By Horace Hutchinson, the Right Hon. A. J. BAlfour, MI.P. Sir WALTer G. Sinirson, Bart. and othe Writers. [In the press.

Riding. By IV. R. WEIR, the EARL OF SUFFolK AND BERKSHIRE, the DUKE OF BEAUFORT, and A. E. T. WATSON.

[In the press.

Tennis, Lawn Tennis, Racquets, and Fives. liy C. G. and J. M. Heaticote, E. O. Plevilell-BouVERIE, and A. C. AINGER. [In the press.

Yachting. By Lord Brassey, Lord DUNRAVEN, and other Writers.

[In preparation. 
Bagwell. - IRELAND ONDER THE TUDORS, with a Succinct Account of the Earlier History. By RICHARD BAGWELL, M.A. (3 vols.) Vols. I. and II. From the first invasion of the Northmen to the year 1578 . Svo. $32 s$. Vol. III. $1578-1603$.

Bain. - WORKS BY ALEXANDER BAIN, LL.D.

MENTAL AND MORAL SCIENCE. Crown 8vo. ros. $6 \%$.

SENSES AND TIIE INTELLECT. Svo. I5s. EMOTIONS AND THE IVILL. Svo. I 5 s. LOGIC, DEDUCTIVE AND INDUCTIVE. Part I. Deduction, 4s. PART II. Induction, 6s. $6 d$.

PRACTICAL ESSAYS. Cr. 8vo. $2 s$.

Baker.-BY THE IVESTERN SEA: a Summer Idyll. By JaMes BAKER, Author of 'John Westacott' \&c. Crown Svo. 6s.

Baker. - 'WAR IVITH CRIME': being a Selection of Reprinted Papers on Crime, Prison Discipline, \&c. By T. BARWick Ll. BAKER. 8vo. 12s. 6d.

Baker.-WORKS BY SIR S. W. BAKER.

EIGHT YEARS IN CEYLON. CrOwn 8vo. Woodcuts. $5 s$.

THE RIFLE AND THE HOUND IN CEYLON. Crown 8vo. Woodcuts. 5s.

Bale.- $A$ HANDBOOK FOR STEAM USERS; being Notes on Steam Engine and Boiler Management and Steam Boiler Explosions. By M. PowIS BALE, M.I.M.E. A.M.I.C.E. Fcp. 8vo. 2s. $6 d$.

Ball.-WORKS BY THE RT. HON.J.T. BALL, LL.D. D.C.L.

THE REFORMED CHURCH OF IRELAND (I 537-I886). 8vo. 7s. 6d.

HISTORICAL REVIEIV OF THE LEGISLATIVE SYSTEMS OPERATIVE IN IRE$L A N D$, from the Invasion of Henry the Second to the Union (1 1 72-180o). 8vo.6s.

Barker.- $A$ SHORT MANUAL OF SURGICAL OPERATIONS. By A. E. J. BARKER, F.R.C.S. With 6r Woodcuts. Crown 8vo. 12s. $6 d$.

Barnett.-PRACTICABLE SOCIALISM: Essays on Social Reform. By the Rev. S. A. BARNetT, M.A. and Mrs. BAR. NETT. Crown 8vo, 2s. $6 d$.

Becker.-WORKS BY PROFESSOR BECKER, translated from the German by the Rev. F. METCALF.

GALLUS; or, Roman Scenes in the Time of Augustus. Post 8vo. 7s. $6 d$.

CHARICLES; or, Illustrations of the Private Life of the Ancient Greeks. Post 8vo. $7 s, 6 d$.
Beaconsfield.-WORKS BY THE EARL OF BEACONSFIELD, K.G.

NOVELS AND TALES. The Hughenden Edition. With 2 Portraits and 11 Vignettes. II vols. Crown Svo. 42s.

Endymion. $\quad$ Henrietta Temple.

Lothair. $\quad$ Contarini Fleming, \&c

Coningsby. Alroy, Ixion, \&c.

Tancred. Sybil. The Young Duke, \&c.

Venetia.

NOVELS AND TALES. Cheap Edition, complete in $\mathbf{I I}$ vols. Crown 8vo. Is. each, boards; $1 s .6 d$. each, cloth.

Bennett and Murray.- $A$ HANDBOOK OF CRYPTOGAIIC BOTANY. By A. W. BennetT, M.A. B.Sc. F.L.S. and GEorge R. MuLNE MuRRAY, F.L.S. With 378 Illustrations. Svo. I6s.

Bennett.-CLINICAL LECTURES ON VARICOSE VEINS OF THE LOWER EXTREMITIES. By WilliAM H. BENNETT, F.R.C.S. Surgeon to St. George's Hospital; Lecturer on Clinical Surgery and on Anatomy in St. Gcorge's Hospital Medical School. With 3 Plates. Svo.

Bentley.-ATEXT-BOOK OF ORGANIC MATERIA MEDICA. BY ROBT. BENTLEY, M.R.C.S.Eng. F.L.S. With 62 Illustrations. Crown 8 vo. $7 s .6 d$.

Book (The) of Wedding Days. Arranged on the Plan of a Birthday Book. IVith 96 Illustrated Borders, Frontispiece, and Title-page by WALTER CRANE; and Quotations for each Day. Compiled and Arranged by K. E. J. Reid, May Ross, and Mabel Bamfield. 4to. $21 s$.

Boultbee.-A COMMENTARY ON THE 39 ARTICLES of the Church of England. By the Rev. T. P. Boultbee. Cr.8vo.6s.

Bourne.-WORKS BY TOHN BOURNE.

CATECHISM OF THE STEAM ENGINE in its various Applications in the Arts, to which is now added a chapter on Air and Gas Engines, and another devoted to Useful Rules, Tables, and Memoranda. Illustratcd by 212 Woodcuts. Crown 8 vo. $7 s .6 d$.

HANDBOOK OF THE STEAM ENGINE; a Key to the Author's Catechism of the Steam Engine. With 67 Woodcuts. Fcp. 8vo. 9s.

RECENT IMPROVEMENTS IN THE STEAM ENGINE. With 124 Woodcuts. Fcp. 8vo. 6s.

BOwen. - HARROW SONGS AND OTHER VERSES. By EDWARD E. Bowen. Fcp. 8vo. $2 s$ 6d. 
Bowen. - THIRTY YEARS OF COLONIAL GOVERNMENT: a Selection from the Official Papers of the Right Hon. Sir George Ferguson Bowcn, G.C.M.G. D.C.L. LI.D. \&c. successively Governor of Queensland, New Zealand, Victoria, Mauritius, and Hong Kong. WVith Portrait on Steel. Edited by STANLEY LANE-POOLE 2 vols. 8vo.

Brassey. - WORKS BY LADY BRASSEY.

A VOYAGE IN THE 'SUNBEAM', OUR HOME ON THE OCEAN FOR ELEVEN MONTHS.

Library Edition. With 8 Maps and Charts, and i I 8 Illustrations, 8vo. 2 Is.

Cabinet Edition. With Map and 66 Illustrations, crown 8 vo. $7 s .6 d$.

School Edition. With 37 Illustrations, fcp. 2s. cloth, or $3 s$. white parchment with gilt edges.

Popular Edition. With 6o Illustrations, 4to. $6 d$. sewed, Is. cloth.

SUNSHINE AND STORMI IN THE EAST.

Library Edition. With 2 Maps and I I Illustrations, 8vo. 2 Is.

Cabinet Edition. With 2 Maps and I I 4 Illustrations, crown 8vo. 7s. $6 d$.

Popular Edition. With $\mathrm{r} 03$ Illustrations, 4to. $6 d$. sewed, Is. cloth.

IN THE TRADES, THE TROPICS, AND THE 'ROARING FORTIES.'

Cabinet Edition. With Map and 220 Illustrations, crown 8vo. 7s. $6 \pi$.

Popular Edition. With 183 Illustrations, 4to. $6 d$. sewed, is. cloth.

THE LAST VOYAGE TO INDIA AND AUSTRALIA IN THE 'SUNBEAM.' With Charts and Maps, and 40 Illustrations in Monotone (20 full-page), and nearly 200 Illustrations in the Text from Drawings by R. T. PritcheTt. 8vo. 2 Is.

THREE VOYAGES IN THE 'SUNBEAM.' Popular Edition. With 346 Illustrations, 4to. 2s. $6 d$.

Bray.-THE PHILOSOPHY OF NECESSITX; or, Law in Mind as in Matter. By Charles Bray. With Portrait. Crown 8vo. 5 s.

Brinkley's Astronomy. Re-edited and Revised by J. WV. Sturbs, D.D. and F. BRunnow, Ph.D. With 49 Diagrams. Crown 8vo. 6s.

Browne.-AN EXPOSITION OF THE 39 ARTICLES, Historical and Doctrinal. By E. H. BRowne, D.D., Bishop of IVinchester. 8 vo. $16 s$.

Bryant.-EDUCATIONAL ENDS; or, the Ideal of Personal Development. By Sophie Bryant, D.Sc.Lond. Crown 8 vo. 6s.
Buckle.-HISTORY OF CIVILISATION IN ENGLAND AND FRANCE, SPAIN AND SCOTLAND. By HENRT ThOMAS BUCKLE. 3 vols. crown 8 vo. 245 .

Buckton.-WORKS BY MRS. C. $M$. BUCKTON.

FOOD AND HOME COOKERY. With II Woodcuts. Crown 8vo. 2s. 6d.

HEALTH IN THE HOUSE. With 4I Woodcuts and Diagrams. Crown 8vo. $2 s$.

Bull.-WORKS BY THONTAS BULL. HINTS TO MOTHERS ON THE MANAGEMENT OF THEIR HEALTH during the Period of Pregnancy and in the Lying-in Room. Fcp. 8vo. Is. 6d.

THE MATERNAL MANAGEMENT OF CHILDREN IN HEALTH AND DISEASE. Fcp. 8vo. Is. 6 .

Bullinger.- $A$ CRITICAL LEXICON AND CONCORDANCE TO THE ENGLISH AND GREEK NEW TESTAMENT. By the Rev. E. W. Bullinger, D.D. Royal 8 vo. I5s.

Burdett.-PRINCE, PRINCESS, AND PEOPLE: an Account of the Social Progress and Development of our own Times, as illustrated by the Public Life and Work of their Royal Highnesses thc Prince and Princcss of Wales, I $86_{3}$-I 889 . By HerRY C. BurdetT. Svo. $2 \mathrm{I} s$.

Carlyle. - THONAS AND JANE WELSH CARLYLE.

THOMAS CARLYLE, a History of his Life. By J. A. Froude, M.A. Vols. I. and II. I 795-I835, 8vo. 32s. Tols. III. and IV. I $834-188 \mathrm{I}, 8$ vo. $32 s$.

LETTERS AND MEMORIALS OF JANE WELSH CARLYLE. Prepared for publication by THOMAS CARLYLE, and edited by J. A. FrOUde, M.A. 3 vols. 8 vo. $36 s$.

Case.-PHYSICAL REALISAT; being an Analytical Philosophy from the Physical Objects of Science to the Physical Data of Scnse. By Thomas Case, M.A. Fellow and Senior Tutor C.C.C. 8vo. I 5 s.

Cecil. - NOTES OF MY JOURNEY ROUND THE WORLD. By Evely CeCIL. With 5 Plates. I vol. 8 vo. I2s. $6 d$.

Chisholm. - HANDBOOK OF COMMERCIAL GEOGRAPIIX. By G. G. CHISIIOLI, M.A., B.Sc. With 29 Maps. Svo. I6s.

Churchill. - SPEECIIES BY LORD RANDOLPII CHURCIIILL, M1.P. Selected and Edited, with an Introduction and Notes, by Louis J. Jennings, M.P. 2 vols. Sro. 24 s. 
Clavers, the Despot's Champion: a Scots Biography. By A Soutiern. Crown 8vo. 7s. 6d.

Clerk.-THE GAS ENGINE. By Dugald Clerk. With ror Illustrations and Diagrams. Crown 8ro. 7 s. $6 \%$.

Clodd.-THE STORY OF CREATION: a Plain Account of Evolution. By EDWARD ClODD. With 77 Illustrations. Crown 8vo. 6s.

Clutterbuck. - TIE SKIPPER IV ARCTIC SEAS. By W. J. ClutTeriuck, one of the Authors of 'Three in Norway.' With numerous Illustrations. Crown Svo.

Coats.-A MANUAL OF PATHOLOGY. By Joseph CoAts, M.D. Pathologist to the Western Infirmary and the Sick Children's Hospital, Glasgow. With 364 Illustrations. 8vo. 3 Is. $6 d$.

Colenso. - THE PENTATEUCH AND BOOK OF FOSHUA CRITICALLY EXAMINED. By J. IV. Colenso, D.D. late Bishop of Natal. Crown 8vo. $6 s$.

Comyn.-Atherstone Priory: a Tale. By L. N. Comyn. Cr. 8ro. 2s.6d.

Conder. - A IIANDBOOK TO THE BIBLE, or Guide to the Study of the Holy Scriptures derived from Ancient Monuments and Modern Exploration. By $F$. R. CONDER, and Lieut. C. R. CONDER, R.E. Post 8vo. 7s. 6d.

Conington. - WORKS BY TOHN CONINGTON, M.A.

THE AENEID OF VIRGIL. Translated into English Verse. Crown 8vo. 6s.

ThE POEMS OF VIRGIL. Translated into English Prose. Crown 8vo. 6s.

Conybeare \& Howson. - THE LIFE AND EPISTLES OF ST. PAUL. By the Rev. W. J. Conymeare, M.A. and the Very Rev. J. S. Howson, D.D.

Library Edition. 2 vols. 8vo. 2 Is.

Student's Edition. I vol. crown 8vo. 6s.

Cooke. - TABLETS OF ANATOMY. By Thomas CoOKE, F.R.C.S. Eng. B.A. B.Sc. M.D. Paris. $\Lambda$ selection of the Tablets believed to be most useful to Students generally. Post 4 to. $7 s .6 d$.

Coolidge. - SWISS TRAVEL AND SivisS GUIDE-BOoKs. By W. A. B. Conlidise, Fellow of Magdalen College, Oxford, and Editor of the Alpine Foumal. Crown 8vo. Ios. $6 d$.
Cox.-A General History OF GREECE : from the Earliest Period to the Death of Alexander the Great; with a Sketch of the History to the Present Time. By the Rev. Sir G. W. Cox, Bart., M.A. With I I Maps and Plans. Crown 8vo. $7 s .6 d$.

Crawford.-REMINISCENCES OF FoREIGN TRAVEL. By ROBERT CRAWFord, M.A. Author of 'Across the Pampas and the Andes.' Crown Svo. $5^{s}$.

Creighton. - HISTORY OF THE PAPACY DURING THE REFORMATION. By the Rev. M. CREIGHTON, M.A. 8vo. Vols. I. and II. I378-I464, 32s.; Vols. III. and IV. I464-I5 I 8, 245 .

Crookes. - SELECT METHODS IN CHEMICAL ANALYSIS (chiefly Inorganic). By William Crookes, F.R.S. V.P.C.S. With 37 Illustrations. 8vo. 24 s.

Crump. - Works bY ARThUR CRUMP:

A SHORT ENQUiRy INTO THE FORMATION OF POLITICAL OPINION, from the Reign of the Great Families to the Advent of Democracy. 8vo. 7s. 6d.

AN INVESTIGATION INTO THE CAUSES OF THE GREAT FALL IN PRICES WHICH TOOK PLACE COINCIDENTLY WITH TIIE DEMONETISATION OF SILVER BY GERMIANY. Sro. 6 s.

Culley.-IIANDBOOK OF PRACTICAL TELEGRAPHY. By R. S. Culley, M. Inst. C.E. Plates and Woodcuts. 8vo. $16 s$.

Curzon.-RUssia IN CENTRAL Asia IN I889 AND THE ANGLO-RUSSIAN QUESTION. By the Hon. GeORGE $N$. Curzon, M.P. Fellow of All Souls' College, Oxford. With Illustrations, Maps, Áppendices, and an Index. I vol. Svo. 2Is.

Davidson.-AN INTRODUCTION TO THE STUDY OF THE NEW TESTAMENT, Critical, Exegetical, and Theological. By the Rev. S. Davidson, D.D. LL.D. Revised Edition, 2 vols. 8vo. 3 Os.

Davidson.-WORKS BY WILLIAM L. DAVIDSON, M.A.

THE LOGIC OF DEFINITION EXPLAINED AND APPLIED. Crown 8vo. 6 s.

LEADING AND IMPORTANT ENGLISH WORDS EXPLAINED AND EXEMPLIFIED. Fcp. 8vo. 3s. $6 d$.

De Redcliffe.-THE LIFE OF THE RIGHT IION. STRATFORD CANNING: VISCOUNT STRATFORD DE REDCLIFFE. By Stanley LANe-Poole. With 3 Portraits. 2 vols. Svo. 36 s. 
De Salis. - WORKS BY MRS. DE SALIS.

Savouries A LA MODE. Fcp. 8vo. Is. boards.

ENTREES A LA MODE. Fcp. 8vo. I s. $6 d$. boards.

SOUPS AND DRESSED FISH $A$ LA MODE. FCp. 8vo. Is. 6d. boards.

Oysters à la MODE. Fcp, 8vo. Is. $6 d$. boards.

SWEETS AND SUPPER DISHES A LA MODE. Fcp. Svo. Is. 6d. boards.

DRESSED VEGETABLES A LA MODE. Fcp. Svo. Is. 6d. boards.

DRESSED GAME AND POULTRY A LA MODE. Fcp. 8vo. is. 6d. boards.

PUDDINGS AND PASTRY A LA MODE. Fcp. Svo. Is. $6 d$. boards.

CAKES AND CONFECTIONS A LA MODE. Fcp. 8vo. Is. 6d. boards.

De Tocqueville. DEMOCRACY IN AMERICA. BY Alexis DE TOCQUEVille. Translated by Henry ReEve, C. B. 2 vols. crown 8 vo. I6s.

Deland.-WORKS BY MRS. DELAND. JOHN WARD, PREACHER: a Story. Crown 8vo. Cabinet Edition, 6s. ; Popular Edition, 2s. boards, 2s. $6 d$. cloth.

THE OLD GARDEN, and other Verses. Fcp. 8 vo. 5 s.

FLORIDA DAYS. With r 2 Full-page Plates (2 Etched and 4 in Colours), and about 50 Illustrations in the Text, by LOUIS K. HARLOW. 8vo. 2 Is.

Dickinson.-WORKS BY W. HOWSHIP DICKINSON, M.D. CANTAB.

ON RENAL AND URINARY AFFECTIONS. With I 2 Plates and 122 Woodcuts. 3 vols. Svo. $63.4 s .6 d$.

THE TONGUE AS AN INDICATOR OF DISEASE : being the Lumbeian Lectures delivered at the Royal College of Physicians in March IS88. 8vo. 7s. 6d.

Dixon.-RURAL BIRD LIFE; Essays on Ornithology, with Instructions for Preserving Objects relating to that Science. By Charles Dixon. With 45 Woodcuts. Crown 8vo. $5 s$.

DOwell.-A HISTORY OF TAXATION AND TAXES IN ENGLAND FROM THE EARLIEST TIMES TO THE YEAR I 885. By Stephen Dowell, Assistant Solicitor of Inland Revenue. Second Edition, Revised and Altered. (4 vols. 8vo.) Vols. I. and II. The History of Taxation, 2Is. Vols. III, and IV. The History of Taxes, 2 Is.
Doyle. -THE OFFICIAL BARONAGE OF ENGLAND. By JAMES E. DOYLE. Showing the Succession, Dignities, and Offices of every Peer from 1066 to I 885 . Vols. I. to III. With I, 600 Portraits, Shields of Arms, Autographs, \&c. 3 vols. 4 to. 65.5 s.

Doyle.-WORKS BY J. A. DOYLE, Fellow of All Souls College, Oxford.

THE ENGLISH IN AMERICA: VIRGINIA, MARYLAND, AND THE CAROLINAS. 8vo. I 8 s.

THE ENGLISH IN AMERICA: THE PURITAN COLONIEs. 2 vols. 8 vo. $36 s$.

Doyle.-MICAH CLARKE: his Statement ; with some Account of his Journey from Havant to Taunton with Decimus Saxon in the Summer of 1685 . Also of the Adventures that befell them during the Western Rebellion, and of their intercourse with James Duke of Monmouth, Lord Grey, and other Persons of Quality. By A. Conan Doyle. Crown 8vo. 6s.

\section{Dublin University Press Series} (The) : a Series of Works undertaken by the Provost and Senior Fellows of Trinity College, Dublin.

Abbott's (T. K.) Codex Rescriptus Dublinensis of St. Matthew. 4to. 2 Is.

Evangeliorum Versio Ante. hieronymiana ex CodiceUsseriano (Dublin. ensi). 2 vols. crown Svo. 2 Is.

Allman's (G. J.) Greek Geometry from Thales to Euclid. 8vo. Ios. $6 \%$.

Burnside (W. S.) and Panton's (A. W.) Theory of Equations. 8vo. I 2s. $6 d$.

Casey's (John) Sequel to Euclid's Elements. Crown 8vo. $3 s .6 d$.

Analytical Geometry of the Conic Sections. Crown Svo. $7 s .6 d$.

Davies's (J. F.) Eumenides of Eschylus. With Metrical English Translation. Svo. $7 s$.

Dublin Translations into Greek and Latin Verse. Edited by R. Y. Tyrrell. 8vo. I $2 s .6 d$.

Graves's (R. P.) Life of Sir William Hamilton. 3 vols. I 5 s. each.

Griffin (R. W.) on Parabola, Ellipse, and Hyperbola, Crown Svo. 6s.

Hobart's (W. K.) Medical Language of St. Luke. Svo. I 6 s.

Leslie's (T. E. Cliffe) Essays in Political Economy. Svo. Ios. 6\%.

Macalister's (A.) Zoology and Morphology of Vertebrata. Svo. IOs. 6 \%

[Continued on next page. 
Dublin University Press Series (The)-continuted.

MacCullagh's (James) Mathematical and other Tracts. Svo. I 5 s.

Maguire's (T.) Parmenides of Plato, Text with Introduction, Analysis, \&c. 8vo. $7 s .6 d$.

Monck's (W. H. S.) Introduction to Logic. Crown Sro. 5 s.

Purser's (J. M.) Manual of Histology. Fcp. Svo. 5 s.

Roberts's (R. A.) Examples in the Analytic Geometry of Plane Curves. Fcp. 8vo. $5^{5}$.

Southey's(R.) Correspondence with Caroline Bowles. Edited by E. Dowden. 8vo. 14s.

Thornhill's (WV. J.) The Aneid of Virgil, freely translated into English Blank Verse. Crown 8vo. 7s. 6d.

Tyrrell's (R. Y.) Cicero's Correspondence. Vols. I. and II. 8vo. each I2s.

The Acharnians of Aristophanes, translated into English Verse. Crown 8vo. 2s. 6 6 .

Webb's (T. E.) Goethe's Faust, Translation and Notes. 8vo. I2s. $6 d$.

The Veil of Isis : a Series

of Essays on Idealism. 8vo. Ios. $6 d$.

Wilkins's (G.) The Growth of the Homeric Poems. 8vo. 6s.

Edersheim.-WORKS BY THE REV. ALFRED EDERSHEIM, D.D.

THE LIFE AND THMES OF JESUS THE MESSIAH. 2 vols. 8vo. 24s.

PROPHECY AND HISTORY IN RELATION TO THE MESSIAH: the Warburton Lectures, I880-I884. 8vo. I2s.

Ellicott. - WORKS $\quad B Y$ C. $\mathcal{F}$. ELLICOTT, D.D. Bishop of Gloucester and Bristol.

A CRITICAL and GRammatical COMMENTARY ON ST. PAUL'S EPISTLES. 8 vo.

I. Corinthians. i6s.

Galatians. $8 s .6 \pi$.

ERHESIANS. $8 s, 6 d$.

Pastoral Epistles. Ios. $6 d$.

Philippians, Colossians, and Philemon. ros. $6 d$.

Thessalonians. $75.6 d$.

HISTORICAL LECTURES ON THE LIFE OF OUR LORD FESUS CHRIST. 8vo. I2S.

Ellis. -MEMTOR OF WILLIAM ELLIS, AND AN ACCOUNT OF HIS CONDUCTTEACIING. By ETHEL E. ELLIS. With a Portrait. 8 vo. $6 s$.
English Worthies. Fcp. 8vo. Is. each, sewed; Is. 6\%. each, cloth.

Darwin. By Grant Allen.

Marlborough. By G. Saintsbury.

SHAFTESBURY (The First Earl). By

H. D. TRAILL.

ADMIRAL BLAKE. By DAVID

IANNAY.

RALEIGH. By Edmund Gossr.

SteEle. By Austin Dobson.

Ben Jonson. By J. A. Symonds.

CanNing. By Frank H. Hill.

CLAVERHOUSE. By Mowbray MORRIS.

Erichsen.-WORKS BY JOHN ERIC ERICHSEN, F.R.S.

THE SCIENCE AND ART OF SURGERY: Being a Treatise on Surgical Injuries, Diseases, and Operations. With I, 025 Illustrations. 2 vols. 8 vo. 48 s.

ON CONCUSSION OF THE SPINE, NERvous SHOCKS, and other Obscure Injuries of the Nervous System, Cr. 8vo. Ios. $6 d$.

Ewald. - WORKS BY PROFESSOR HEINRICH EWALD, of Göttingen.

The Antiquities of IsRael. Translated from the German by $\mathrm{H}$. S. Soldy, M.A. 8vo. I $2 s .6 d$.

THE HISTORY OF ISRAEL. Translated from the German. \& vols. Svo. Vols. I. and II. 24s. Vols. III. and IV. 2Is. Vol. V. ISs. Vol. VI. I6s. Vol. VII. 21s. Vol. VIII. with Index to the Complete Work. I8s.

Fairbairn.-WORKS $B Y$ SIR $W$. FAIRBAIRN, BART. C.E.

A TREATISE ON MILLS AND MILLWORK, with 18 Plates and 333 Woodcuts. I vol, 8vo. 25 s.

USEFUL INFORMATION FOR ENGINEERS. With many Plates and Woodcuts. 3 vols, crown 8 vo. 3 Is. $6 d$.

Farrar. - LANGUAGE AND LANGUAGES. A Revised Edition of Chapters on Language and Families of Speech. By F. W. FARRAR, D.D. Crown 8vo. 6s.

Firth.-OUR KIN ACROSS THE SEA. By J. C. FirTir, of Auckland, Newr Zealand. With a Preface by Mr. Froude. Fcp. Svo. 6s.

Fitzwygram. - HoRSES AND STABLES. By Major-General Sir F. FitzwYGRAM, Bart. With 19 pages of Illustrations. 8 vo. $5^{s}$. 
Fletcher.-CHARACTERS IN 'MACBETII.' Extracted from 'Studies of Shakespeare.' By GEORGE FletCher, 1847. Crown 8vo. 2s. 6\%.

Forbes. - A Courst: of Lectures ON ELECTRICITY, delivered before the Society of Arts. By GEORGE FORBES. With 17 Illustrations. Crown 8vo. 5 s.

Ford.-THE THEORY AND PRACTICE OF ARCHERY. By the late HORACE Ford. New Edition, thoroughly Revised and Re-written by W. Butr, M.A. With a Preface by C. J. Longman, M.A. F.S.A. Svo. I 4 s.

Fox.-THE EARLY HISTORY OF CHARLES FAMES FOX. By the Right Hon. Sir G. O. Trevelyan, Bart.

Library Edition, 8vo. I8s.

Cabinet Edition, cr. 8vo. 6 s.

Francis.- $A$ BOoK oN ANGLING; or, Treatise on the Art of Fishing in every branch; including full Illustrated List of Salmon Flies. By Francis Francis. Post 8 vo. Portrait and Plates, I.5s.

Freeman.-THE IISTORICAL GEOGRAPIIY OF EUROPE. BY E. A. FREEMAN. With 65 Maps, 2 vols. 8vo. 3 Is. $6 d$.

Froude. WORKS BY JAMES $A$. FROUDE.

THE HISTORY OF ENGLAND, from the Fall of Wolsey to the Defeat of the Spanish Armada.

Cabinet Edition, I 2 vols. cr. 8vo. $\Varangle 3$. I2s. Popular Edition, I2 vols. cr. 8vo. E2. $2 s$.

SHORT STUDIES ON GREAT SUBFECTS. 4 vols. crown Svo. 24 s.

CESAR: a Sketch. Crown 8vo. 6s.

THE ENGLISH IN IRELAND IN THE EIGHTEENTH CENTURY. 3 vols. crown 8vo. I 8 s.

OCEANA; OR, ENGLAND AND HER COLONIES. With 9 Illustrations. Crown 8vo. 2s. boards, 2s. $6 d$. cloth.

THE ENGLISH IN THE WEST INDIES; OR, THE BOW OF ULYSSES. With 9 Illustrations. Crown 8vo. 2s. boards, 2s. $6 d$. cloth.

THE TWO CIIIEFS OF DUNBOY; or, an Irish Romance of the Last Century. Crown 8vo. $6 s$.

THOMAS CARLYLE, a History of his Life, I795 to 1835.2 vols. 8vo. $32 s$. I 834 to 188 I. 2 vols. 8 vo. $32 s$.

Gairdner and Coats.-ON THE DrSEASES CLASSIFIED BY THE REGISTRARGENERAL AS TABES MESENTERICA. By W. T. Gairdier, M.D. LL.D. ON THE PATHOLOGY OF PHTIISIS PULMONALIS. By JOSEPH COATS, M.D. With 28 Illustrations. 8vo. I2s. $6 d$.
Galloway. - THE FUNDAMENTAL PRINCIPLESOF CHEMISTRY PRACTICALLY TAUGIIT BY A NEW METHOD. By Robert Galloway, M.R.I.A. Cr. 8vo. $6 s .6 d$.

Ganot. - WORKS BY PROFESSOR GANOT. Translated by E. ATKinson, Ph.D. F.C.S.

ELEMENTARY TREATISE ON PHYSICS. With 5 Coloured Plates and 923 Woodcuts. Crown 8vo. I5s.

NATURAL PHILOSOPHY FOR GENERAL READERS AND YOUNG PERSONS. With 2 Plates, 518 Woodcuts, and an Appendix of Questions. Cr. 8vo. 7s. 6d.

Gardiner. - WORKS BY SAMUEL RAWSON GARDINER, LL.D.

HISTORY OF ENGLAND, from the Accession of James I. to the Outbreak of the Civil IVar, 1603-1642. Io vols. crown 8 vo. price $6 s$. each.

A History of the Great CiviL WAR, 1642-1649. (3 vols.) Vol. I. I642-1644. With 24 Maps. 8vo. 2Is. Vol. II. 1644-1647. With 21 Maps. Svo. 24 s.

Garrod.-WORKS BY SIR ALFRED BARING GARROD, M.D. F.R.S.

A TREatise oN GoUT aND RHEU. MATIC GOUT (RHEUMATOID ARTHRITIS). With 6 Plates, comprising 2 I Figures (14 Coloured), and 27 Illustrations engraved on Wood. Svo. 2 Is.

THE ESSENTIALS OF MATERIA MEDICA AND THERAPEUTICS. New Edition, revised and adapted to the New Edition of the British Pharmacopœia, by Nestor Tirard, M.D. Cr. 8vo. 12s.6d.

Gerard.-ORTHODOX: a Novel. By Dorothea Gerard. Crown 8ro. 6s.

Gibbs. - ENGLAND AND SOUTH AFrica. By EDMund J. Gibis. Svo.

Gibson-A TEXT-BOOK OF ELEMENTARY BIOLOGY. By R. J. HARVEY Ginson, M.A. With 192 Illustrations. Fcp. 8vo. 6s.

Godolphin.-THE LIFE OF THE EARL OF GODOLPHIN, Lord High Treasurer 1702-1710. By the Hon. Hugir ElLIOT, M.P. 8vo. 15 s.

Goethe.-FAUST. A New Translation, chiefly in Blank Verse; with Introduction and Notes. By JAMes Adey Birds. Crown 8vo. 6s.

FAUST. The Second Part. A New Translation in Verse. By James Adey BIRDS. Crown Svo. 6 s. 
Gray. - ANATOMY, Descriptive aNd SURgical. By Henry Gray, F.R.S. With 569 Woodcut Illustrations, a large number of which are coloured. Re-edited by T. PICKering Pick. Royal 8vo. $36 s$.

Green.-THE WORKS OF THOMAS HILL GREEN, late Whyte's Professor of Moral Philosoply, Oxford. Edited by R. L. NetTleship, Fellow of Balliol College (3 vols.) Vols. I. and II.Philosophical Works. 8vo. I6s, each. Vol. III.-Miscellanies. With Index to the three Volumes and Memoir. 8vo. 2Is.

THE WITNESS OF GOD, AND FAITH: Two Lay Sermons. By T. H. GrEEN. Fcp. 8vo. 2s.

Greville. - A TOURNAL OF THE REIGN'S OF KING GEORGE IV. KING WILLIAM IV. AND QUEEN VICTORIA. By the late C. C. F. GReville, Esq. Edited by H. ReEve, C.B. Cabinet Edition. 8 vols. Crown 8 vo, 6s, each.

Gwilt.-AN ENCYCLOPAEDIA OF ARCHITECTURE. By JOSEPH GWILT, F.S.A. Illustrated with more than 1,700 Engravings on Wood. Revised by WyatT PAPWORTH. 8vo. 52s. 6d.

Haggard.-WORKS BY H. RIDER HAGGARD.

SHE. With 32 Illustrations by M. GREIFFENHAGEN and C. H. M. KeRR. Crown 8 vo. 3 s. $6 d$.

AlLaN Quatermain. With 3 I Illustrations by C. II. M. KERR. Crown 8vo. 3s. 6d.

MAIVA'S REVENGE; OR, THE WAR OF THE LITTLE HAND. Crown 8vo. $2 s$. boards; $2 s .6 d$. cloth.

Colonel Quaritch, V.C. A Novel. Crown 8vo. $6 s$.

CLEOPATRA : being an Account of the Fall and Vengeance of Harmachis, the Royal Egyptian, as set forth by his own hand. With 29 Full-page Illustrations by M. Greiffenhagen and R. Caton Woodville. Crown 8vo. $6 s$.

Hargreaves.-LITERARYIVORKERS; or, Pilgrims to the Temple of Honour. By John George Ifargreaves, M.A. 4to. $7 s .6 d$.

Harrison.-ON THE CREATION AND PIIYSICAL STRUCTURE OF TIE EARTI: an Essay. By JOHN THORNIIILL HARRISON, F.G.S. M.Inst.C.E. With 6 Maps. 8vo. 7 s. $6 d$.
Harte.-NOVELS BY BRET HARTE. IN the Carquinez WoOds. Fcp. 8 vo. I $s$. boards; Is. $6 d$. cloth. ON THE FRONTIER. I6mo. Is. BY SHORE AND SEDGE. I6mo. Is.

Hartwig. - WORKS BY DR. HARTWIG. THE SEA AND ITS LIVING WONDERS. With 12 Plates and 303 Woodcuts. 8vo. IOs. $6 d$.

THE TROPICAL WORLD. With 8 Plates, and 172 Woodcuts. 8vo. Ios. $6 \%$.

THE POLAR WORLD. With 3 Maps, 8 Plates, and 85 Woodcuts. 8 vo. Ios. $6 d$.

THE SUBTERRANEAN WORLD. With 3 Maps and 8o Woodcuts. 8vo. Ios. $6 d$. THE AERIAL WORLD. With Map, 8 Plates, and 6o Woodcuts. 8 vo. Ios. $6 d$.

The following books are extracted from the foregoing works by Dr. HARTwIG :-

HEROES OF THE ARCTIC REGIONS. With I9 Illustrations. Crown 8vo. $2 s$. cloth extra, gilt edges.

WONDERSOF THE TROPICAL FORESTS. With 40 Illustrations. Crown 8vo. 2s. cloth extra, gilt edges.

WORKERS UNDER THE GROUND; or, Mines and Mining. With 29 Illustrations. Crown 8 vo. 2s, cloth extra, gilt edges.

MARVELS OVER OUR HEADS. With 29 Illustrations. Crown 8vo. 2s. cloth extra, gilt edges.

MARVELS UNDER OUR FEET. With 22 Illustrations. Crown 8vo. 2s. cloth extra, gilt edges.

DWELLERS IN THE ARCTIC REGIONS. With 29 Illustrations. Crown 8vo. 2s. $6 d$. cloth extra, gilt edges.

WINGED LIFE IN THE TROPICS. With 55 Illustrations. Crown Svo. 2s. $6 d$. cloth extra, gilt edges.

VOLCANOES AND EARTHQUAKES. With 30 Illustrations. Crown Svo. 2s. $6 d$. cloth extra, gilt edges.

WILD ANIMALS OF THE TROPICS. With 66 Illustrations. Crown $S$ vo. $3 s .6 d$. cloth extra, gilt edges.

SEA MONSTERS AND SEA BIRDS. With 75 Illustrations. Crown 8 vo. $2 s .6 d$. cloth extra, gilt edges.

DENIZENS OF THE DEEP. With I I 7 Illustrations. Crown 8vo. 2s. 6d. cloth extra, gilt edges.

Hassall. - THE INHALATION TREATMENT OF DISEASES OF TIIE ORGANS OF RESPIRATION, including Consumption. By Arthur Hill Hassall, M.D. With 19 Illustrations of Apparatus. $\mathrm{Cr}$. 8 vo. 12s, $6 d$. 
Havelock. - MEIIOIRS OF SIR HENRY HAVELOCK, K.C.B. By JOHN Clark Marshman. Crown 8vo. $3 s .6 \%$.

Hearn.-THE GOVER NMENT OF ENG$L A N D$; its Structure and its Development. By William Edward Hearn, Q.C. 8 vo. $16 s$.

Helmholtz. - WORKS BY PROFESSOR HELMHOLTZ.

ON THE SENSATIONS OF TONE AS A PHYSIOLOGICAL BASIS FOR THE THEORY OF MUSIC. Royal Svo. 28 s.

Popular Lectures on SCIENTific SUBYECTS. With 68 Woodcuts. 2 vols. Crown 8 vo. 15 s. or separately, $7 s .6 d$. each.

Herschel.-OUtLINES OF AstroNOMY. By Sir J. F. W. HersChel, Bart. M.A. With Plates and Diagrams. Square crown 8 vo. I2s.

Hester's Venture : a Novel. By the Author of 'The Atelier du Lys.' Crown 8vo. 2s. 6d.

Hewitt. - THE DIAGNOSIS AND TREATMENT OF DISEASES OF WOMEN, INCLUDING THE DIAGNOSIS OF PREG. NANCY. By Graily HewitT, M.D. With 2 II Engravings. 8 vo. 24s.

Higginson. - THE AFTERNOON LANDSCAPE: Poems and Translations. By ThOMAS WENTWORTH Higginson, Colonel U.S. Army. Fcp. 8vo. 5s.

Historic Towns. Edited by E. A. FREEMAN, D.C.L. and Rev. WILLIAM Hunt, M.A. With Maps and Plans. Crown 8vo. $33^{s} 6 d_{0}$ e eich.

LONDON. BY W. E. LOFTIE.

EXETER. By E. A. Freemar.

BRISTOL. By IV. Hunt.

OXFORD. BY C. IV. BOASE.

Colchester. By E. L. Cutts.

Cinque Ports. By Montagu BURROWS.

Carlisle. By Mandell CreighTON.

Holmes.-A SYSTEM OF SURGERY, Theoretical and Practical, in Treatises by various Authors. Edited by TIMoTHY Holmes, M.A. and J. W. HUlke, F.R.S. 3 vols. royal 8 vo. £4. $4 s$.

Hopkins.-CHRIST THE CONSOLER; a Book of Comfort for the Sick. By Ellice Hopkins. Fcp. 8vo. 2s. $6 d$.

Howitt. - VISITS TO REMARKABLE PLACES, Old Halls, Battle-Fields, Scenes illustrative of Striking Passages in English History and Poetry. By William HowiTT. With 8o lilustrations engraved on Wood. Crown 8vo. 5 s.
Hudson \& Gosse.-THE'ROTIFERA, OR 'WHEEL-ANIMALCULES.' By C. T. Hudson, LL. D. and P. H. Gosse, F.R.S. With 30 Coloured and $4 \mathrm{Un}$ coloured Plates. In 6 Parts. 4to. ros. $6 \%$. each; Supplement, I2s. $6 d$. Complete in 2 vols. with Supplement, 4 to. $£ 4.4 s$.

Hullah.-WORKS BY JOHN HULLAH. COURSE OF LECTURES ON THE HISTORY OF MODERN MIUSIC. 8vo. 8s.6d.

COURSE OF LECTURES ON THE TRANSITION PERIOD OF MUSICAL HISTORY. 8 vo, ros, $6 d$.

Hume.-THEPHILOSOPHICAL WORKS OF DAVID HUNE. Edited by T. H. Green and T. H. Grose. 4 vols. 8vo. 56s. Or separately, Essays, 2 vols. 28s. Treatise of IIuman Nature. 2 vols. 28s.

Hurlbert.-FRANCE AND HER REPUBLIC: a Record of Things Seen and Heard in the 'Centennial Year,' I889. By WM. Henry Hurlbert, Author of 'Ireland under Coercion.'

Hutchinson. - WORISS BY HORACE G. HUTCHINSON.

CRICKETING SAIVS AND STORIES. Consisting of scraps of advice to duffers (chiefly on points of cricketing culture) by one of them-of saws not sharp enough to hurt anybody, and of stories picked up between the innings. With rectilinear Illustrations by the Author. $16 \mathrm{mo}$. Is.

THE Record of A HUMAN SOUL. Fcp. 8vo. 3s. 6d.

Huth.-THE MARRIAGE OF NEAR $K I N$, considered with respect to the Law of Nations, the Result of Experience, and the Teachings of Biology. By Alfred H. Huth. Royal Svo. 2Is,

In the Olden Time: a Tale of the Peasant War in Germany. By Author of 'Mademoiselle Mori.' Cr. 8vo. 2s, 6d.

Ingelow.-WORKS $B Y$ JEAN INGELOW.

POETICAL WORKES. Vols. I. and II. Fcp. 8vo. I2s. Vol. III. Fcp. 8vo. 5s.

LYRICAL AND OTHER POEMS. Selected from the Writings of JEAN INGELOW. Fcp. 8vo. 2s. 6d. cloth plain; 3 s. cloth gilt.

Irving.-PIIYSICAL AND CHEMICAL STUDIES IN R'OCK-METAMORPHISI, based on the Thesis written for the D.Sc. Degree in the University of London, IS88. By the Rcv. A. IRviNG, D.Sc.Lond. 8 vo. $5^{s}$. 
James.-THE LONG WHTTE MOUNTAIV; or, a Journey in Manchuria, with an Account of the History, Administration, and Religion of that Province. By H. E. James, of Her Majesty's Bombay Civil Service. With Illustrations and a Map. I vol. Sro. $24 s$.

Jameson.-WORKS BY MRS. JAMESON.

LEGENDS OF THE SAINTS AND MARTYRS. With 19 Etchings and 187 IVoodcuts. 2 vols. 3 Is. $6 d$.

LEGENDS OF THE MADONNA, the Virgin Mary as represented in Sacred and Legendary Art. With 27 Etchings and 165 Woodcuts. I vol, $21 \mathrm{~s}$.

LEGENDS OF THE MONASTIC ORDERS. With II Etchings and 88 Woodcuts. I vol. 2 Is.

HISTOR Y OF THE SAVIOUR, His Types and Precursors. Completed by Lady EASTLAKE. With 13 Etchings and 28I Woodcuts. 2 vols. $42 s$.

Jefferies.-FIELD AND HEDGEROW: last Essays of RICHARD JEFFERIES. Crown 8vo. 6s.

Jenkin. - PAPERS, LITERARY, SCIENTIFIC, E⿱一. By the late FLEEMING JENKIN, F.R.S.S. L. \& E. Edited by Sidney Colvin, M.A. and J. A. Eving, F.R.S. With Memoir by ROBERT LouIS STEVENSON. 2 vols. 8 vo. $32 s$.

Jessop.-JUDGE LYNCII: a Tale of the California Vineyards. By George II. Jessop, Crown 8vo. 6s.

Johnson.-THE PATENTEE'S MAN$U A L ;$ a Treatise on the Law and Practice of Letters Patent. By J. JoHnson and J. H. JoHnson. 8vo. IOs. $6 d$.

Johnston.-A GENERAL DICTION$A R Y$ OF GEOGRAPHY, Descriptive, Physical, Statistical, and Historical ; a complete Gazetteer of the World. By KeITH JoHnston. Medium 8vo. 42s.

Johnstone.- $A$ SHORT INTRODOCTION TO THE STUDY OF LOGIC. By Laurence Johnstone. Crown Svo. $2 s .6 d$.

Jordan. - WORKS BY WILLIAM LEIGHTON JORDAN, F.R.G.S.

THE OCEAN: a Treatise on Ocean Currents and Tides and their Causes. Svo. 2 Is.

THE NEW PRINCIPLES OF NATURAL PHILOSOPHY. With 13 plates. 8vo. 2 Is.

THE WINDS : an Essay in Illustration of the New Principles of Natural Philosophy. Crown Svo. 2s.

THE STANDARD OF VALUE. SvO. $6 \mathrm{~s}$.
Jukes.-WORKS BY ANDREW JUKES.

THE NEW MAN AND THE ETERNAL LIFE. Crown 8vo. 6s.

THE TYPES OF GENESIS. Crown 8vo. 7s. 6d.

THE SECOND DEATH AND THE RESTITUTION OF ALL THINGS. Crown 8vo. 3s. $6 d$.

THE MYSTERY OF THE KINGDOM. Crown 8vo, 2s. $6 d$.

THE NAMES OF GOD IN HOLY SCRIPTURE: a Revelation of His Nature and Relationships. Crown Svo. 4s. $6 d$.

Justinian. - THE INSTITUTES OF FUSTINIAN; Latin Text, chiefly that of Huschke, with English Introduction, Translation, Notes, and Summary. By Thomas C. Sandars, M.A. 8vo. I8s.

Kalisch. - WORKS $B Y$ M. $M$. KALISCH, M.A.

BIbLE STUDIEs. Part I. The Prophecies of Balaam. 8vo. Ios. $6 d$. Part II. The Book of Jonah. 8vo. Ios. $6 d$.

Commentary ON THE OLD TESTA$M E N T$; with a New Translation. Vol. I. Genesis, 8vo. I8s. or adapted for the General Reader, I2s. Vol. II. Exodus, I5s. or adapted for the General Reader, I2s. Vol. III. Leviticus, Part I. I5s. or adapted for the General Reader, $8 s$. Vol. IV. Leviticus, Part II. I5s. or adapted for the General Reader, $8 s$.

HEBREW GRAMMAR. With Exercises. Part I. 8vo. I2s. 6d. Key, 5s. Part II. I 2s, $6 d$.

Kant. - WORKS BY IMMANUEL KANT. CRITIQUE OF PRACTICAL REASON, AND OTHER WORKS ON THE THEORY OF ETHICS. Translated by T. K. Abbott, B.D. With Memoir and Portrait. 8vo. I2s. $6 d$.

INTRODUCTION TO LOGIC, AND HIS ESSAY ON THE MISTAKEN SUBTILTY OF THE FOUR FIGURES. Translated by T. K. Abbott. With Notes by S. T. Coleridge. 8 vo. 6 s.

Kendall.-WORKS BY MAY KEN$D A L L$.

From a G.akret. Crown 8vo. 6s. DREAMS to SELL; Poems. Fcp. 8 vo. 6s.

'SUCH IS LIFE': a Novel. Crown 8vo. 6s.

Killick.- HANDBOOK TO MILL'S SYSTEM OF LOGIC. By the Rev. A. H. KILlick, M.A. Crown 8 vo. 3 s. $6 d$. 
Kirkup.-AN INQUIRY INTO SOCIALISM. By Thumas Firkup, Author of the Article on 'Sociailism" in the "Ency. clopredia Britannica.' Crown 8vo. $5 s$.

Kolbe.-A ShORT TEXT-BOOK OF INORGANIC CHEMISTRY. By Dr. HerMANN KOLBE. Translated from the German by T. S. HuMPIDGE, Ph.D. With a Coloured Table of Spectra and 66 Illustrations. Crown 8 vo. 7 s. $6 d$.

Ladd. - ELEMENTS of PhysioloGICAL PSYCHOLOGY: a Treatise of the Activities and Nature of the Mind from the Physical and Experimental Point of View. By George T. LADd. Svo, 2 Is.

Lang.-WORKS BY ANDREW LANG. MYTH, RITUAL, AND RELIGION. 2 vols. crown 8 vo. 2 Is.

CUstom AND MYTH; Studies of Early Usage and Belief. With 15 Illustrations. Crown 8vo. 7s. 6 d.

Letters to Dead Authors. Fcp. 8vo. 6s. 6d.

BOOKS AND BOOKMEN. With 2 Coloured Plates and I 7 Illustrations. $\mathrm{Cr}$. 8vo. 6s. 6d.

Grass of PARnassus. A Volume of Selected Verses. Fcp. Svo. 6s.

LETTERS ON LITERATURE. Crown 8vo. 6s. 6d.

BALLADS OF BOOKS. Edited by ANDREW LANG. Fcp. Svo. $6 s$.

THE BLUE FAIRY BOOK. Edited by ANDREW LANG. With numerous IIlustrations by II. J. Ford and Gr. P. Jacomb Hood. Crown 8vo. $6 s$.

Laughton.-STUDIES IN NAVAL HISTORY; Biographies. By J. K. LAughton, M.A. 8vo. 10s. 6d.

Lavigerie.-CARDINAL LAVIGERIE AND SLAVERY IN AFRICA. I vol. 8vo.

Lecky.-WORKS BY W.E. H. LECKY. HISTORY OF ENGLAND IN THE EIGHTEENTH CENTURY. 8vo. Vols. I. \& II. 1700-1760. 36s. Vols, III. \& IV. I 760-I 784. 36s. Vols, V. \& VI. 1784-1 793. 36s.

THE HISTOR Y OF EUROPEAN MORALS FROM AUGUSTUS TO CHARLEMAGNE. 2 vols. crown 8vo. $16 s$.

HISTORY OF THE RISE AND INFLUENCE OF THE SPIRIT OF RATIONALISM IN EUROPE. 2 vols. crown 8vo. $16 s$.
Lees and Clutterbuck.-B.C. r887, A RAMBLE IN BRITISII COLUMBIA. By J. A. Lees and W. J. Clutterbuck, Authors of 'Three in Norway.' IVith Map and 75 Illustrations from Sketches and Photographs by the Authors. Crown 8vo. 6s.

Lewes.-THE History OF PhILOSOPHY, from Thales to Comte. By George Henry Lewes. 2 vols, 8vo. 32s.

\section{Light through the Crannies.-} Parables and Teachings from the other Side. First Series. Crown Svo. Is. sewed; 1 s. $6 d$. cloth.

Lindt.-PICTURESQUE NEW GUINEA. By J. W. Lindt, F.R.G.S. With 50 Full-page Photographic Illustrations, 4to. 425 .

Liveing.-WORKS BY ROBERT LIVEING, M.A. and M.D. Cantab.

HANDBOOK ON DISEASES OF THE SKIN. Fcp 8vo. 5 s.

Notes oN THE TREATMENT OF SKIN DISEASES. I ISMO. 3 S.

Lloyd.-A TREATISE ON MAGNETISM, General and Terrestrial. By $\mathrm{H}$. Lloyd, D.D. D.C.L. 8vo. Ios. 6d.

Lloyd.-THE SCIENCE OF AGRICUL. TURE. By F. J. LlOYd, 8vo. 12s.

Longman.-HISTORY OF THE LIFE AND TIMES OF EDWARD IIT. By WILliam LoNGMaN. 2 vols. 8 vo. $28 s$.

Longman.-WORKS BY FREDERICK W. Longman, Balliol College, Oxon. Chess OPENINGS. Fcp. 8vo. 2s. 6d. FREDERICK THE GREAT AND THE SEVEN YEARS' WAR. Fcp. SVO. 2s. 6d.

A NEW POCKET DICTIONARY OF THE GERMAN AND ENGLISH LAN GUAGES. Square $18 \mathrm{mo}$. 2s. $6 d^{\circ}$

Longman's Magazine. Published Monthly. Price Sixpence.

Vols. I-14, 8vo. price 5s. each.

Longmans' New Atlas. Political and Ihysical. For the Use of Schools and Private Persons. Consisting of 40 Quarto and 16 Octavo Maps and Diagrams, besides Insets and 16 Quarto Plates of Views, \&c. Engraved and Lithographed by EDWARD STANFORD. Edited by Geo. G. Chisholm, M.A. B.Sc. Imp. 4to. or imp. 8vo. 12s. 6 . 
Longmore.-WORKS BY SURGEONGENERAL SIR T. LONGMORE.

GUNSHOT INYURIES; their History, Characteristic Features, Complications, and General Treatment. With 58 Illustrations. 8vo. 3Is. $6 d$.

THE ILLUSTRATED OPTICAL MaNUAL; or, Handbook of Instructions for the Guidance of Surgeons in Testing Quality and Range of Vision, and in Distinguishing and dealing with Optical Defects in General. With 74 Drawings and Diagrams. 8vo. 14 s.

Loudon.-WORKS BY J. C. LOUDON, F.L.S.

ENCYCLOPIEDIA OF GARDENING. With I, 00o Woodcuts. 8vo. 2 Is.

ENCYCLOPAEDIA OF AGRICULTURE; the Laying-out, Improvement, and Management of Landed Property. With I, 100 Woodcuts. 8vo. 2 Is.

ENCYCLOPAEDIA OF PLANTS; the Specific Character, \& c. of all Plants found in Great Britain. With 12,000 Woodcuts. Svo. $42 s$.

Lubbock.-THE ORIGIN OF CIVILIzaTION AND THE PRIMITIVE CONDITION of MAN. By Sir J. LUBBock, Bart. M.P. F.R.S. With Illustrations. 8 vo. $18 \mathrm{~s}$.

Lyall.-THE AUTOBIOGRAPHY OF A SLANDER. By EDNa Lyall, Author of 'Donovan,' 'We Two,' \&c. Fcp. 8vo. Is. sewed.

Lyra Germanica ; Hymns Translated from the German by Miss C. WinkwORTH. FcP. 8vo. 5 s.

Macaulay.-WORKS AND LIFE OF LORD MACAULAY.

HISTORY OF ENGLAND FROM THE ACCESSION OF FAMES THE SECOND:

Popular Edition, 2 vols. crown 8vo. 5 s.

Student's Edition, 2 vols. crown 8vo. I $2 s$.

People's Edition, 4 vols. crown 8vo. I6s.

Cabinet Edition, 8 vols. post 8 vo. 48 s.

Library Edition, 5 vols. 8vo. 64 .

CRITICAL AND HISTORICAL ESSAYS, with LAYS of ANCIENT RoME, in I volume :

Popular Edition, crown 8vo. 2s. $6 d$.

Authorised Edition, crown 8vo. 2s. $6 d$. or $3^{s .} 6 d$. gilt edges.

CRITICAL AND HISTORICAL ESSAYS:

Student's Edition, I vol. crown 8 vo. $6 s$.

People's Edition, 2 vols, crown 8vo. 8s.

Cabinet Edition, 4 vols. post 8vo. 245 .

Library Edition, 3 vols. 8vo. 36 s.

[Continued above.
Macaulay-WORKS AND LIFE OF LORD MACAULAY-continued.

ESSAYS which may be had separately price $6 d$. each sewed, Is. each cloth :

Addison and Walpole.

Frederick the Great.

Croker's Bosivell's Johnson.

Hallam's Constitutional History.

Warren Hastings. ( $3 d^{d}$. sewed, $6 d$. cloth.)

The Earl of Chatham (Two Essays).

Ranke and Gladstone.

Milton and Machiavelli.

Lord Bacon.

Lord Clive.

Lord Byron, and The Comic Dramatists of the Restoration.

The Essay on Warren Hastings annotated by S. Hales, Is. $6 d$.

The Essay on Lord Clive annotated by H. Courthope Bowen, M.A. 2s. $6 d$.

SPEECHES :

People's Edition, crown 8vo. 3s. 6d.

MISCELLANEOUS WRITINGS:

People's Edition, I vol. crown 8vo. 4s. 6a.

Library Edition, 2 vols. 8vo. 2 Is.

LAYS OF ANCIENT ROME, \&.c.

Illustrated by G. Scharf, fcp. 4to. Ios. $6 d$.

18mo, 2s. 6d. gilt top.

Bijou Edition, Popular Edition, fcp. 4to. $6 d$. sewed, 1s. cloth.

Illustrated by J. R. Weguelin, crown 8 vo. 3s. $6 d$. cloth extra, gilt edges.

Cabinet Edition, post 8vo. 3s. $6 d$.

Annotated Edition, fcp. 8vo. Is. sewed Is.6d. cloth, or $2 s .6 d$. cloth extra, gilt edges.

MISCELLANEOUS WRITINGS AND SPEECHES :

Popular edition, I vol. crown 8 vo. 2s. $6 d$.

Student's Edition, in I vol. crown 8vo. $6 s$.

Cabinet Edition, including Indian Penal Code, Lays of Ancient Rome, and Miscellaneous Poems, 4 vols. post 8 vo. 24 s.

SELECTIONS FROM THE WRITINGS OF LORD MACAULAY. Edited, with Oc. casional Notes, by the Right Hon. Sir G. O. Trevelyan, Bart. Crown 8vo.6s.

COMPLETE WORKS OF LORD MACAULAY.

Library Edition, 8 vols. 8 vo. 65.5 s.

Cabinet Edition, 16 vols. post 8vo. $£ 4$. I6s.

THE LIFE AND LETTERS OF LORD MACAULAY. By the Right Hon. Sir G. O. Trevelyan, Bart.

Popular Edition, I vol. crown 8vo. 2s. $6 d$. Student's Edition, I vol. crown 8vo. $6 s$.

Cabinet Edition, 2 vols. post 8vo. $12 s$.

Library Eảition, 2 vols. 8vo. 36 s. 
Macdonald.-WORKS BY GEORGE MACDONALD, LL.D.

UNSPOKEN SERMONS. First and Second Series. Crown 8vo. 3s.6d. each. Third Series. Crown 8vo. 7s. 6d.

THE MiRacLes OF OUR LORD. Crown 8vo. 3s. 6d.

A BOOK OF STRIFE, IN THE FORM OF THE DIARY OF AN OLD SOUL: Poems. $12 \mathrm{mo}$. $6 \mathrm{~s}$.

Macfarren.-WORKS BY SIR G. A. MACFARREN:

LECTURES ON HARMONY, delivered at the Royal Institution. 8vo. 12s.

ADDRESSES AND LECTURES, delivered at the Royal Academy of Music, \&c. Crown 8vo. 6s. 6\%.

Macleod.-WORKS BY HENRY $D$. MACLEOD, M.A.

THE ELEMENTS OF BANKING. Crown 8 vo. 5 s.

The Theory and Practice of BANKING. Vol. I. Svo. 12s. Vol. II. I4s.

THE THEORY OF CREDIT. 2 vols. Svo. Vol. I. 7s. $6 d$.

$$
\text { [Vol. II. in the press. }
$$

McCulloch. - THE DictionaRY OF COMMERCE AND COMMERCIAL NAVIGATION of the late J. R. MCCULLOCH, of H.M. Stationery Office. Latest Edition, containing the most recent Statistical Information by A. J. WILSON. I vol. medium 8vo. with II Maps and 30 Charts, price $63 \mathrm{~s}$. cloth, or $70 s$. strongly halfbound in russia.

MCDougall.-MEMOIRS OF FRANCIS THOMAS MCDOUGALL, D.C.L.F.R.C.S. sometime Bishop of Labuan and Sarawak, and of Harriette his Wife. By her Brother, Charles John Bunyon. Svo.

Mademoiselle Mori: a Tale of Modern Rome. By the Author of 'The Atelier du Lys.' Crown 8vo. 2s. $6 d$.

Mahaffy.-A HISTORY OF CLASSICAL GREEK LITERATURE. By the Rev. J. P. Mahaffy, M.A. Crown 8 vo. Vol. I. Poets, 7s. $6 d$. Vol. II. Prose Writers, 7s. 6d.

Malmesbury. - MEMOIRS OF AN EX-MINISTER: an Autobiography. By the Earl of Malmesbury, G.C.B. Crown 8vo. 7 s. $6 d$.

Manning.-THE TEMPORAL MISSION OF THE HOLY GHOST; or, Reason and Revelation. By II. E. MANning, D.D. Cardinal-Archbishop. Crown 8 vo $8 s .6 d$.
Manuals of Catholic Philosophy (Stonyhurst Series):

Logic. By Richard F. Clarke, S.J. Crown 8vo. 5 s.

FIRST PRINCIPLES OF KNOWLEDGE. By John Rickaby, S.J. Crown 8vo. 5 s. Moral Philosophy (Ethics and NATURAL LAW . By Josepir RickabY, S.J. Crown Sro. 5 s.

Natural Theology. By Bernard Boedder, S.J. Crown 8vo. 6s. $6 d$.

[Nearly ready.

Psychology. By Michael Maher, S.J. Crown 8vo. 6s. 6d. [Preparing.

General Metaphysics. By John RICKABY, S.J. Crown 8vo. 5 s.

$$
\text { [Preparing. }
$$

Martin.-NAVIGATION AND. NAUTICAL ASTRONOMY. Compiled by StaffCommander IV. R. MARTIN, R.N. Sanctioned for use in the Royal Navy by the Lords Commissioners of the Admiralty. Royal Svo, 18 s.

Martineau-WORKS BY JAMES MARTINEAU, D.D.

HOURS OF THOUGHT ON SACRED THINGS. Two Volumes of Sermons. 2 vols. crown 8 vo. $7 s, 6 d$. each.

ENDEAVOURS AFTER THE CHRISTIAN LIFE. Discourses. Crown 8vo, $7 s, 6 d$.

Matthews.-PEN AND INK. Papers on Subjects of More or Less Importance. By Brander Matthews. Crown 8vo. 5 s.

Maunder's Treasuries.

BIOGRAPHICAL TREASORY. Edited by W. L. R. Cates. New Edition, with Supplement brought down to 1889 , by Rev. Jas. WOOD. Fcp. 8vo. 6s.

TREASURY OF NATURAL HISTORY; or, Popular Dictionary of Zoology. Fcp. 8vo. with 900 Woodcuts, $6 s$.

TREASORY OF GEOGRAPHY, Physical, Historical, Descriptive, and Political. Witll 7 Maps and 16 Plates. Fcp. 8vo. 6s. SCIENTIFIC AND LITERARY TREASURY. FCP. 8vo. 6s.

HISTORICAL TREASURY: Outlines of Universal History, Separate Histories of all Nations. Revised by the Rev. Sir G. W. Cox, Bart. M.A. Fcp. Svo. 6s.

TREASURY OF KNOWLEDGE AND LIBRARY OF REFERENCE. Comprising an English Dictionary and Graminar, Universal Gazetteer, Classical Dictionary; Chronology, Law Dictionary, \&c. Fcp. 8 vo. 6s.

[Continued on next page. 
Maunder's Treasuries-continued.

THE TREASURY OF BIELE KNOWLEDGE. By the Rev. J. AYRE, M.A. With 5 Maps, i 5 Plates, and 300 Woodcuts. Fcp. 8vo. 6s.

THE TREASURY OF BOTANY. Edited by J. Lindley, F.R.S. and T. MOORE, F.L.S. With 274 Woodcuts and 20 Steel Plates, 2 vols. fcp. 8ro. I2s.

Max Müller.-WoRkS BY F. MAX MÜLLER, M.A.

BIOGRAPHICAL ESSAYS. Crown 8vo. $75,6 d$.

SELECTED EsSAYS ON LANGUAGE, MYTHOLOGY AND RELIGION. 2 vols. crown 8 vo. I6s.

LECTURES ON THE SCIENCE OF LANGUAGE. 2 vols. crown 8 vo. I6s.

THREE LECTURES ON THE SCIENCE OF LANGUAGE AND ITS PLACE IN GENERAL EDUCATIOV, delivered at the Oxford University Extension Meeting, I889. Crown 8vo, $2 s$.

INDIA, WHAT CAN IT TEACH US? A Course of Lectures delivered before the University of Cambridge. 8vo. I2s. $6 d$.

HIBDERT LECTURES ON THE ORIGIN AND GROWTH OP RELIGION, as illustrated by the Religions of India. Crown 8 vo. 7 s. $6 d$.

INTRODUCTION TO THE SCIENCE OF RELIGION: Four Lectures delivered at the Royal Institution. Crown 8vo. 7s.6d.

NATURAL RELIGION. The Gifford Lectures, delivered before the University of Glasgow in I 888 . Crown 8vo. Ios. $6 d$.

THE SCIENCE OF THOUGHT. 8vo. 2 Is.

BIOGRAPHIES OF WORDS, AND THE HOME OF THE ARYAS. Crown 8vo. 7s.6 6 .

A SANSKRIT GRAMmar FOR BEGINNERS. New and Abridged Edition. By A. A. MacDonell. Crown 8vo. 6s.

May.-THE Constitutional HisTORY OF ENGLAND SINCE THE ACCESSION OF GEORGE III. I760-1870. By the Right Hon. Sir ThOMAS ERSKine MAY, K.C.B. 3 vols. crown 8vo. I8s.

Meath.-WORKS BY THE EARL OF MEATH (Lord Brabazon).

SOCIAL ARrows: Reprinted Articles on various Social Subjects. Cr. 8vo. 5 s.

PROSPERITY OR PAUPERISM? Physical, Industrial, and Technical Training. (Edited by the EARL OF MIEATH). 8vo. 5 s.
Melbourne. - THE

MELBOURNE PAPERS: being a Selection from Documents in the possession of Earl Cowper, K.G. Edited by Lloyd C. SANDERS, B.A. With Preface by Eari Cowper I vol. 8 vo.

Melville.-NOVELS BY G.J. WHYTE MELVILLE. Crown Svo. Is. each, boards; Is. $6 d$. each, cloth.

The Gladiators.

The Interpreter.

Good for Nothing.

The Queen's Maries.

Holmby House.

Kate Coventry.

Digby Grand.

General Bounce.

Mendelssohn.-THE LETTERS OF FELIX MENDELSSOHN. Translated by Lady WALLACE. 2 vols. crown 8vo. IOS.

Merivale.-WORKS BY THE VERY REV. CHARLES MERIVALE, D.D.' Dean of Ely.

HISTORY OF THE ROMANS UNDER THE EMPIRE. 8 vols. post 8 vo. 48 s.

THE FALL OF THE ROMAN REPUBLIC: a Short History of the Last Century of the Commonwealth. I2mo. 7s. $6 d$.

GENERAL HISTORY OF ROME FROM B.C. 753 TO A.D. 476 . Crown 8vo. 7s. 6d.

THE ROMAN TRIUMVIRATES. With Maps. Fcp. 8vo, 2s, $6 d$.

Meyer.-MODERN THEORIES OF CHEMISTRY. By Professor LOTHAR MEYER. Translated, from the Fifth Edition of the German, by P. PHiclips BEDSON, D.Sc. (Lond.) B.Sc. (Vict.) F.C.S.; and W. Carleton Villiams, B.Sc. (Vict.) F.C.S. Svo. I8s.

Mill.-ANALYSIS OF the PHENoMENA OP THE HUMAN MIND. By JAMES MILL. With Notes, Illustrative and Critical. 2 vols. Svo. 28s.

Mill.-WORKS BY JOHN STUART MILL.

PRINCIPLES OF PoLITICAL ECONOMY. Library Edition, 2 vols. Svo. 30 s.

People's Edition, I vol. crown 8vo. 5 s.

A System of Logic, Ratiocinative and Inductive. Crown 8vo. $5^{5 .}$

ON LIBERTY. Crown 8vo. Is. $4 \pi$. ON REPRESENTATIVE GOVERNMENT. Crown Svo. $2 s$.

UTILITARIANISMT. 8vo. 5 s.

EXAMINATION OF SIR WILLIAM HAMILTON'S PHILOSOPHY. Svo. I6s. NATURE, THE UTILITY OF RELIGION, AND THEISM. Three Essays. 8vo. 5 s. 
Miller. - WORKS BY W. ALLEN MILLER, M.D. LL.D.

THE ELEMENTS OF CIIEMISTRY, Theoretical and Practical. Re-edited, with Additions, by H. MACLEOD, F.C.S. 3 vols. 8 vo.

Vol. I. Chemical Physics, ís.

Vol. II. Inorganic Chemistry, 24 s.

Vol. III. ORganic Chemistry, 3 Is. $6 d$.

AN INTRODUCTION TO THE STUDY OF INORGANIC CHEMISTRY. With 7I Woodcuts. Fcp. 8vo. 3s. $6 d$.

Mitchell.-A MANUAL OF PRACTICAL AssaYtNG. By John Mitcheli, F.C.S. Revised, with the Recent Discoveries incorporated. By W. CrookEs, F.R.S. 8vo. Woodcuts, 3Is. 6d.

Mitchell.-Dissolution AND EVOLUTION AND THE SCIENCE OF MEDICINE : an Attempt to Co-ordinate the necessary Facts of Pathology and to Establish the First Principles of Treatment. By C. Pitfield Mitciiell. Svo, i6s.

Molesworth. - MARRYING AND GIVING IN MARRIAGE: a Novel. By Mrs. MOLesworth. Fep. 8vo. 2s. 6d.

Nozley.-THE IVORD. By the Rev. T. MozLEy, Author of 'Reminiscences of Oriel College and the Oxford Movement.' Crown Svo.

Mulhall.-HISTOR Y OF PRICES SINCE THE YEAR I850. By MICHAEL G. Mulhall. Crown 8vo. $6 \mathrm{~s}$.

Murchison.-WORKS BY CHARLES MURCHISON, M.D. LL.D. ENC.

A Treatise on the Continued FEVERS OF GREAT BRITAIN. Revised by W. Cayley, M.D. Physician to the Middlesex Hospital. 8vo. with numerous Illustrations, $25 \mathrm{~s}$.

Clinical Lectures oN Diseases OF THE LIVER, FAUNDICE, AND ABDOMINAL DROPSY. Revised by T. LAUDER BRUNTON, M.D. and Sir JOSEPH FAYRER, M.D. 8vo. with 4.3 Illustrations, $24 s$.

Murray.-A DANGERoUS CATSPAW: a Story. By David Christie Murray and Henry Murray. Crown 8vo. 6s.

Murray.-GODI OR SIIAMO: a Story of Three Songs. (The Great Desert of Gobi or Shamo.-Cornwell's Gcography.) By G. G. A. Murray, New College, Oxford. I vol. crown Svo.

Murray and Herman. - WILD DARRIE : a Story. By CHRISTIE MU RRAY and Henry Herman. Crown Svo. $6 s$.
Nelson.-LETTERS AND DESPATCHES OF HORATIO, VISCOUNT NELSON. Selected and arranged by JOIN KNOX LAUGH TON, M.A. 8vo. I6s.

Nesbit.-IVORKS BY E. NESBIT.

LAYS AND LEGENDS. Cr. 8vo. 5 s.

LEAVES OF LIFE: Verses. Cr. 8vo. 5 s.

Newman.-ON THE DISEASES OF THE KIDNEY AMENABLE TO SURGICAL TREATMENT. By David NewMaN, M.D. Svo. I6s.

Newman. - WORKS BY CARDINAL NEWMAN.

APOLOGIA PRO VITÁ SUA. Crown 8 vo. 6 s.

THE IDEA OF A UNIVERSITY DEFINED AND ILLUSTRATED. Crown 8vo. 75 .

HISTORICAL SKETCIIES. 3 vols. crown 8vo. 6s. each.

THE ARIANS OF THE FOURTH CENTURY. Crown 8vo. 6s.

SELECT TREATISES OF ST. ATHANASIUS IN CONTROVERSY WITH THE ARIANS. Freely Translated. 2 vols. crown 8 vo. 15 s.

Discussions and ARGUMENTS ON VARIOUS SUBYECTS. Crown 8vo. 6s.

AN ESSAY ON THE DEVELOPMENT OF Christian Doctrine. Crown Svo. 6s.

CERTAIN DIFFICULTIES FELT BY ANGLICANS IN CATITOLIC TEACHING CONSIDERED. Vol. I, crown 8vo. 7s.6 $d_{\text {. }}$; Vol. 2, crown 8 vo. $5^{s} .6 d$.

THE VIA MEDIA OF THE ANGLICAN CHURCH, ILLUSTRATED IN LECTURES Éc. 2 vols. crown 8vo. 6s. each.

ESSAYS, CRITICAL AND HISTORICAL. 2 vols. crown 8 vo. I $2 s$.

ESSAYS ON BIBLICAL AND ON ECCLESIASTICAL MIRACLES. Crown 8vo. 6s.

AN ESSAY IN AID OF A GRAMMAR OF ASSENT. 7s. $6 \mathrm{~d}$.

PRESENT Position of Catholics in $E_{N G L A N D .}$ Crown 8vo. 75 .

CALLISTA: a Tale of the Third Century. Crown 8vo. 6s.

THE DREAM OF GERONTIUS. r 6 mo. $6 d$. sewcd, Is. cloth.

VERSES ON VARTOUS OCCASIONS. Crown 8vo. 6s.

Newnham.-WORES BY THE REV. H. P. NEWNIIAN.

TIIE ALL-FATHER: Sermons preached in a Village Church. With Preface by Edna L.Yall. Cr. 8 vo. 4 s. $6 \pi$.

THY HEART WITII MY HEART: Four Letters on the Holy Communion. r8mo. $3 d$. sewed; $6 d$. cloth limp ; $8 d$. cl. 
Noble.-HoURS WITH A THREE-INCH TELESCOPE. By Captain W. NOBLE. With a Map of the Moon. Cr. 8vo. 4s. $6 d$.

Northcott. - LATHES AND TURNING, Simple, Mechanical, and Ornamental. By W. H. NorthcotT. With 338 Illustrations. 8vo. I $8 \mathrm{~s}$.

Oliphant.-NOVELS BY MRS. OLIPHANT.

MADAM. Cr. 8vo. is. bds.; is. $6 d$. cl. IN TR UST.—Cr. 8vo. Is.bds.; is. $6 d$.cl. $L_{A D Y} C_{A R}$ : the Sequel of a Life. Crown Sro. 6s.

Oliver. - AstronOMY FOR AMATEURS: a Practical Manual of Telescopic Research adapted to Moderate Instruments. Edited by J. A. WVESTwOoD OlIVER. With several Illustrations. Crown Svo. 7 s. $6 d$.

Owen.-A MANUAL OF ANATOMY FOR SENIOR STUDENTS. By EDMUND Owen, M.B. F.R.C.S. Surgeon to St. Mary's Hospital, London, and co-Lecturer on Surgery, late Lecturer on Anatomy in its Medical School. With numerous Illustrations. Crown 8vo.

Owen. - THE COMPARATIVE ANATOMY AND PHYSIOLOGY OF THE VERTEBRATE ANIMALS. By Sir RICHARD OWEN, K.C.B. \&c. With I, 472 Woodcuts. 3 vols. 8vo. £3. 13s. $6 d$.

Paget. - WORKS BY SIR JAMES PAGET, BART. F.R.S. D.C.L. א.C. CLINICAL LECTURES AND ESSAYS. Edited by F. Howard Marsh. 8vo. I $5 \mathrm{~s}$. LECTURES ON SURGICAL PATHOLOGY. Re-edited by the AUTHOR and IV. TURNER, M.B. 8vo. with I3I Woodcuts, 2 Is.

Pasteur.-LOUIS PASTEOR, his Life and Labours. By his SON-IN-LAw. Translated from the French by Lady Claud Hamlion. Crown 8vo. 7s. 6. .

Payen.-INDUSTRIAL ChEMISTRY; a Manual for Manufacturers and for Colleges or Technical Schools ; a Translation of PAYEN's 'Précis de Chimie Industrielle.' Edited by B. H. PAul. With 698 Woodcuts. Medium 8vo. $42 s$.

Payn. - NOVELS BY JAMES PAYN.

THELUCK OFTHE DARRELLS. Crown 8vo. Is. boards; Is. 6 d. cloth.

THICKER THAN WATER. Crown 8vo. Is. boards ; Is. 6 d. cloth.

Pears. - THE FALL of ConstantTNOPLE: being the Story of the Fourth Crusade. By Edvin Pears. 8vo. I6s.
Pennell.-OUR SENTIMENTAL JOURNEY THROUGIT FRANCE AND ITALY. By JOSEPH and ElizabeTh ROBINS PenNell. With a Map and I 20 Illustrations by Joseph Pennell. Crown 8vo. 6s. cloth or vegetable vellum.

Perring.-WORKS BY SIR PHILIP PERRING, B.ART.

HARD KNOTS IN SHAKESPEARE. 8 vo. 7 s. $6 d$.

THE 'WORKS AND DAYS' OF MOSES.

Pole.-THE THEORY OF THE MODERN SCIENTIFIC GAME OF WHIST. By W. Pole, F.R.S. Fcp. 8vo. 2s. 6d.

Pollock.-A NINE MEN'S MORRICE: Stories Collected and Re-collected. By Walter Herries Pollock. Crown Svo. 6s.

Porter.-THE HISTOR Y OFTHE CORPS OF ROYAL ENGINEERS. By MajorGeneral Whitworth PORTER, R.E. 2 vols. 8 vo. $36 s$.

Prendergast.-IRELAND, from the Restoration to the Revolution, I660169o. By JoHN P. PRENDERGAST. 8vo. $5 \mathrm{~s}$.

Proctor.-WORKS BYR.A. PROCTOR. OLD AND NEW ASTRONOMY. I 2 Parts, 2s. 6d. each. Supplenuentary Section, Is. Complete in I vol. 4to. $36 s$. [In course of publication.

THE ORBS AROUND US; a Series of Essays on the Moon and Planets, Meteors and Comets. With Chart and Diagrams, crown 8vo. 5 s.

OTHER WORLDS THAN OURS; The Plurality of Worlds Studied under the Light of Recent Scientific Researches. With I 4 Illustrations, crown 8vo. $5^{s}$.

THE MOON; her Motions, Aspects, Scenery, and Physical Condition. With Plates, Charts, Woodcuts, \&c. Cr. 8vo. $5^{\text {s. }}$

UNIVERSE OF STARS; Presenting Researches into and New Views respecting the Constitution of the Heavens. With 22 Charts and 22 Diagrams, 8vo IOs. $6 d$.

LARGER STAR ATLAS for the Library, in 12 Circular Maps, with Introduction and 2 Index Pages. Folio, I $5^{s}$. or Maps only, I2s. $6 d$.

THE STUDENT'S ATLAS. In Twelve Circular Maps on a Uniform Projection and onc Scale, with Two Index Maps. Vith a letterpress Introduction illustrated by several cuts. 8 vo. 5 s.

NEW STAR ATLAS for the Library, the School, and the Observatory, in 12 Circular Maps. Crown 8vo. 55 .

[Continued on next page. 
Proctor.-WORKSBY R. A. PROCTOR, Continued.

LIGHT SCIENCE FOR LEISURE HOURS; Familiar Essays on Scientific Subjects. 3 vols. crown 8 vo. 5 s. each.

CHANCE AND LUCK; a Discussion of the Laws of Luck, Coincidences, Wagers, Lotteries, and the Fallacies of Gambling \&c. Crown Svo. 2s. boards; $2 s .6 d$. cloth.

STUDIES OF VENUS-TRANSITS; an Investigation of the Circumstances of the Transits of Venus in 1874 and 1882. With 7 Diagrams and ro Plates. 8 vo. $5 \mathrm{~s}$.

HOW TO PLAY WHIST: WITH THE LAWS AND ETIQUETTE OF WHIST. Crown 8vo. $3 s .6 d$.

HoME IVHIST: an Easy Guide to Correct Play. I6mo. Is.

The PoEtry of Astronomy. A Series of Familiar Essays. Crown 8 vo. 5 s.

THE STARS IN THEIR SEASONS An Easy Guide to a Knowledge of the Star Groups, in 12 Large Maps. Imperial 8 vo. 5 s.

STAR PRIMER. Showing the Starry Sky Week by Week, in 24 Hourly Maps. Crown 4to. 2s. 6 d.

The Seasons Pictored in 48 SunVIEWS OF THE EARTH, and 24 Zodiacal Maps, \&c. Demy 4to. 5 s.

STRENGTH AND HAPPINESS. Crown 8vo. 5 s.

STRENGTH : How to get Strong and lieep Strong, with Chapters on Rowing and Swimming, Fat, Age, and the Waist. With 9 Illustrations. Crown Sro. $2 s$.

Rough WAYS MADE SMooth. Familiar Essays on Scientific Subjects. Crown 8 vo. 5 s.

OUR PLACE Among INFinities. A Series of Essays contrasting our Little Abode in Space and Time with the Infinities Around us. Crown 8vo. 5 s.

THE EXPANSE OF HEAVEN. Essays on the Wonders of the Firmament. Crown 8vo. 5 s.

The Great Pyramid, ObServaTORY, TOMB, AND TEMPLE. With Illustrations. Crown 8vo. 5 s.

Pleasant Ways in SCIENCE. Crown Svo. 5 S.

MYTHS AND MARVELS OF ASTRONOMY. Crown 8vo. 5 s.

NATURE STUDiEs. By GRANT Allen, A. IVrlson, T. Foster, E. Clodd; and R. A. I'ROCTOR. Crown 8vo. 5 s.

Leisure Readings. By E. Clodd, A. Wilson, T. Foster, A. C. Ranyard, and R. A. Proctor. Crown 8vo. $5^{s}$.
Prothero.- THE PIONEERS AND PROGRESS OF ENGLISH FARMING. By Rowland E. Prothero. Crown 8 vo. 5 s.

Pryce. - ThE ANCIENT BRITISH CHURCH : an Historical Essay. By JoHN PRYCE, M.A. Canon of Bangor. Crown 8vo. $6 s$.

Quain's Elements of Anatomy. The Ninth Edition. Re-edited by ALLEN THOMSON, M.D.LI.D. F.R.S.S.L. \& E. EdWard Albert Schäfer, F.R.S. and George Dancer Thane. With upwards of $\mathrm{r}, \mathrm{O00}$ Illustrations engraved on Wood, of which many are Coloured. 2 vols. 8 vo. I 8 s, each.

Quain.-A DICTIONARY OF MEDICINE. By Various Writers. Edited by R. QuAIN, M.D. F.R.S. \&c. With 138 Woodcuts. Medium 8vo. 3rs. 6d. cloth, or 40s. half-russia; to be had also in 2 vols. 34 s. cloth.

Rawlinson.-THE HISTORY OF Phavicia. By George Rawlinson, M.A. Canon of Canterbury, \&c. With numerous Illustrations. 8vo. 24 s.

Reader.-WORKS BY EMILY E. READER.

ECHOES OF THOUGHT: a Medley of Verse. Fcp. Svo. 5s. cloth, gilt top.

THE GHOST OF BRANKINSHAW and other Tales. With 9 Full-page Illustrations. Fcp. 8vo. 2s. 6d. cloth extra, gilt edges.

VOICES FROM FLOWER-LAND, in Original Couplets. A Birthday-Book and Language of Flowers. I6mo. is. $6 d$. limp cloth; $2 s .6 d$. roan, gilt edges, or in vegetable vellum, gilt top.

FAIRY PRINCE FOLLOW-MY-LEAD; or, the MAGIC BRACELET. Illustrated by WM. Reader. Crown 8vo. 2s. 6d. gilt edges; or $3 s .6 \%$. vegetable vellum, gilt edges.

Reeve. - COOKERY AND HOUSEKEEPING. By Mrs. Henry ReEve. With 8 Coloured Plates and 37 Woodcuts. Crown 8vo. 5 s.

Rendle and Norman.-THE INNS OF OLD SOUTHWARK, and thcir Associations. By Willia.r RENDLE, F.R.C.S. Author of 'Old Southwark and its People,' and Philip Norman, F.S.A. With numerous Illustrations. Royal Sro. $28 s$.

Reply (A) to Dr. Lightfoot's Essays. By the Author of 'Supcrnatural Rcligion.' I vol. Sro. $6 s$.

Rich.-A DiCTIONARY OF ROMAN AND GREER ANTIQUITIES. With 2,000 Woodcuts. By A. Rici, B.A. Cr. Svo. $7 s .6 d$. 
Richardson.-WORKS BY BENYAMIN WARD RICHARDSON, M.D.

THE HEALTH OF NATIONS : a Review of the Works-Economical, Educational, Sanitary, and Administrative-of EDWIN CHADwICK, C.B. With a Biographical Dissertation by BENJAMIN WARD RICHARDSON, M.D. F.R.S. 2 vols. 8 vo. $28 s$.

THE Commonhealth: a Series of Essays on Health and Felicity for EveryDay Readers. Crown 8vo. 6s.

THE SON OF A STAR: a Romance of the Second Century. Crown 8vo. 6s.

Riley.-Athos; or, the Mountain of the Monks. By Athelstan RiLey, M.A. F.R.G.S. With Map and 29 Illustrations. Svo. 2 Is.

Riley. - OLD-FASHIONED ROSES. Verses and Sonnets. By J. W. RiLEy. Fcp. Svo. 5s.

Rivers. - WORKS BY THOMAS RIVERS. THE ORCHARD-HOUSE. With 25 Woodcuts. Crown 8vo. 5 s.

The Miniature FRUIT GARDEN; or, the Culture of Pyramidal and Bush Fruit Trees, with Instructions for Root Pruning. With 32 Illustrations. Fcp. 8 vo. 4 s.

Roberts.-GREEK THE LANGUAGE OF CHRIST AND HIS APOSTLES. BY ALEXANDER Roberts, D.D. 8vo. I8s.

Robinson. - THE NEW ARCADIA, and other Poems. By A. MARy F. Robinson. Crown 8vo. $6 s$.

Roget.-THESAURUS OF ENGLISH WORDS AND PHRASES, Classified and Arranged so as to facilitate the Expression of Ideas and assist in Literary Composition. By Peter M. Roget. Crown 8vo. xos. $6 d$.

Ronalds. - THE FLY-FISHER's ENTOMOLOGY. BY ALFRED RONALDS. With 20 Coloured Plates. 8vo. 14s.

Russell.-A LIFE OF LORD JOIIN RUSSELL (EARL RUSSELL, K.G.). By Spencer Walpole, Author of 'A History of England from 1815.' With 2 Portraits. 2 vols. 8 vo. 36 s.

Schäfer. - THE ESSENTIALS OF HISTOLOGY, DESCRIPTIVE AND PRACTT. CAL. For the use of Students. By E. A. SCHäFER, F.R.S. With 28x Illustrations. 8vo. 6s. or Interleaved with Drawing Paper, 8s. 6 $d$.
Schellen. - SPECTRUM ANALYSIS IN ITS APPLICATION TO TERRESTRIAL SUBSTANCES, and the Physical Constitution of the Heavenly Bodies. By Dr. H. Schellen. Translated by Jane and Caroline lassell. Edited by Capt. W. De W. Abney. With 14 Plates (including Angström's and Cornu's Maps) and 29I Woodcuts. 8vo. 3Is. 6d.

Scott.-WEATHER CHARTS AND STORM WARNINGS. By ROBERT H. SCOTT, M.A. F.R.S. With numerous Illustrations. Crown 8vo. 6s.

Seebohm.-WORKS BY FREDERIC SEEBOHM.

THE OXFORD REFORMERS-JOHN COLET, ERASMUS, AND THOMAS MORE; a History of their Fellow-IWork. 8vo. 14s.

THE ENGLISH VILLAGE COMMUNITY Examined in its Relations to the Manorial and Tribal Systems, \&c, 13 Maps and Plates. 8vo. 16 s.

THE ERA OF THE PROTESTANT REVOLUTION. With Map. Fcp. 8vo. 2s. 6 d.

Sennett. - THE MARINE STEAMENGINE; a Treatise for the use of Engineering Students and Officers of the Royal Navy. By Richard SENNETT, Engineer-in-Chief of the Royal Navy. With 244 Illustrations. 8vo. 21 s.

Sewell. - StORIES AND TALES. By Elizabeth M. Sewell. Crown 8vo. Is. 6d. each, cloth plain; 2s. $6 d$. each, cloth extra, gilt edges :-

\begin{tabular}{l|l} 
Amy Herbert. & Margaret Percival.
\end{tabular}

The Earl's Daughter. Laneton Parsonage.

The Experience of Life. Ursula.

A Glimpse of the World. Gertrude.

Cleve Hall.

Katharine Ashton.

Shakespeare. - BOWDLER'S $F_{A \text { - }}$ MILY SHAKESPEARE. Genuine Edition, in $I$ vol. medium 8 vo. large type, with 36 Woodcuts, I 4 s. or in 6 vols. fcp. 8 vo. $2 \mathrm{I} s$.

OUTLINES OF THE LIFE OF SHAKESPEARE. By J. O. Halliwell-PhilLITPS, F.R.S. 2 vols. Royal 8vo. ŁI. Is.

SHAKESPEARE'S TRUE LIFE. By JAMES WALTER. With 400 Illustrations. Imp. Svo. I 5 s.

Short.-SKETCH OF THE HISTORY OF THE CHURCH OF ENGLAND TO THE REVOLUTION OF I688. BY T. V. SHORT, D.D. Crown 8vo. 7s. $6 d^{\text {. }}$. 
Slingo and Brooker.-ELECTRICAL ENGINEERING FOR ELECTRIC LIGHT ARTISANS AND STUDENTS. By W. Silngo, Principal of the Telegraphists' School of Science, \&c. and A. BROOKER, Instructor on Electrical Engineering at the Telegraphists' School of Science.

Smith, H. F.-THE HANDBOOK FOR MiDWiVEs. By HeNRY Fly SMith, M.B. Oxon. M.R.C.S. With 4I Woodcuts. Crown 8 ro. 5 s.

Smith, J. H.-THE WHITE UMBRELLA IN MEXICO. WVith numerous Illustrations. By J. Hopkinson SMitH. Fcp. 8vo. 6s. 6d.

Smith, R. Bosworth. - $C_{A R}$ THAGE AND THE CARTHAGINIANS. By R. Bosworth Smith, M.A. Maps, Plans, \&c. Crown 8vo. IOs. $6 d$.

Smith, R. H.-GRAPHICS; or, The Art of Calculation by Drawing Lines, applied to Mathematics, Theoretical Mechanics, and Engineering, including the Kinetics and Dynamics of Machinery, \&c. By RoberT H. SMith.

PART I. Text, with separate Atlas of Plates, 8 vo. I 5 s.

Smith, T.-A MANUAL OF OPERATIVE SURGERY ON THE DEAD BODY. By Thomas Smith, Surgeon to St. Bartholomew's Hospital. A New Edi. tion, re-edited by W. J. Walsham. With 46 Illustrations. 8vo. I2s.

Southey.-THE POETICAL WORKS OF ROBERT SOUTHEY, with the Author's last Corrections and Additions. Medium 8vo. with Portrait, I4s.

Stanley. - A FAMILIAR HISTORY of Birds. By E. Stanley, D.D. Revised and enlarged, with 160 Wood. cuts. Crown 8vo. $6 s$.

Steel.-WORKS BY J. H. STEEL, M.R.C.V.S.

A TREatise on the Diseases of THE DOG ; being a Manual of Canine Pathology. Especially adapted for the Use of Veterinary Practitioners and Students. With 88 Illustrations. 8vo. IOS. 6 d.

A TREatise ON THE Diseases $O F T H E O X$; being a Manual of Bovine Pathology specially adapted for the use of Veterinary Practitioners and Students. With 2 Plates and II7 Woodcuts. 8vo. 15 s.

A TREATISE ON Diseases OF TIIE SHEEP: being a Manual of Ovine $\mathrm{Pa}$ thology for the use of Veterinary Practitioners and Students. Illustrated. Svo.
Stephen. - ESSAYS IN ECCLESIASTICAL BIOGRAPHY. By the Right Hon. Sir J. Stephen, Ll.D. Crown 8vo. $75.6 d$.

Stevenson.-WORKS BY ROBERT LOUIS STEVENSON.

A CHILD'S GARDEN OF VERSES. Small fcp. 8vo. 5 s.

THE DYNAMTTER. Ficp. 8vo. Is. swd. Is. 6 d. cloth.

STRANGE CASE OF DR. JEKYLL AND MR. ITYDE. Fcp. 8vo. Is. sewed; Is. $6 d$. cloth.

Stevenson and Osbourne.-THE WRONG BOX. BY ROBERT LOUIS SteveNson and Lloyd Osbourne. Crown 8vo. 5 s.

Stock. - DEDUCTIVE LogrC. By St. George Stock. Fcp. 8vo. 3s. 6d.

Stockton. - THE GREAT WAR SYNDICATE. By Frank R. STOCKTON, Author of 'Rudder Grange.' Fcp. 8vo. Is. sewed.

'Stonehenge.' - THE DOG $I N$ HEALTH AND DISEASE. By 'STONE. HENGE.' With 84 Wood Engravings. Square crown 8vo. 7s. $6 a^{3}$.

Stoney. - THE THEORY OF THE STRESSES ON GIRDERS AND SIMILAR STRUCTURES. With Practical Observations on the Strength and other Properties of Materials. By Bindon B. STONEY, LL.D. F.R.S. M.I.C.E. With 5 Plates and I43 Illustrations. Royal Svo. $36 s$.

Sully.-WORKS bY JAMES SULLY.

OUTLINES OF PSYCHOLOGY, with Special Reference to the Theory of Education. 8vo, I2s, $6 d$.

THE TEACHER'S HANDBOOK OF PSYCHOLOGY, on the Basis of 'Outlines of Psychology.' Crown 8vo. 6s. 6d.

Sumner.-TIEE BESOM MAKER, AND OTHER COUNTRY FoLK SONGS. Collected and Illustrated by HEYwood SuMner. With Music. 4to. 2s. $6 d$. boards.

Supernatural Religion; an Inquiry into the Reality of Divine Revelation. Complete Edition, thoroughly revised. 3 vols. 8vo. $36 s$.

Swinburne.-PICTURE LOGIC; an Attempt to Popularise the Science of Reasoning. By A. J. Swinburke, B.A. Post 8vo. 5 s.

Tangena Tree (The) : a True Story from Madagascar. By A GNes MARION. Crown Sro. Is. 
Thompson.-WORKS BY D. GREENLEAF THOMPSON.

THE PROBLEM OF EVIL: an Introduction to the Practical Sciences. 8vo. IOs. 6 .

A System of PSychology. 2 vols. 8vo. $36 s$.

THE RELIGIOUS SENTIMENTS OF THE HUMAN MIIND. 8vo. 7s. 6 d.

Social Progress: an Essay. 8vo. $75.6 d$.

Three in Norway. By Two of Them. With a Map and 59 Illustrations from Sketches by the Authors. Cr. 8vo. 2s. boards; $2 s .6 d$. cloth.

Times and Days: being Essays in Romance and History. Fcp. 8vo. $5^{s}$.

Todd. - ON PARLIAMENTARY GoVERVMENT IN ENGLAND: its Origin, Development, and Practical Operation. By Alpheus Todd, LL.D. C.M.G. Second Edition. In Two VolumesVoL. I. 8vo. 24s. Vol. II. 8vo. 30s.

Tomson. - THE BIRD BRIDE: a Volume of Ballads and Sonnets. By Grailam R. Tomson. Fcp. Svo. 6s.

Trevelyan. - WORKS BY THE RIGHT HON. SIR G. O.TREVELYAN, BART.

THE LIFE AND LeTters OF LORD MACAULAY.

Popular EDition, I vol. crown 8 vo. 2s. $6 d$.

S'TUDENT'S EDITION, I vol. cr. 8vo. 6s. CABINET EDITION, 2 vols. cr. 8vo. I2s. LIBRARY EDITION, 2 vols. Svo. $36 \mathrm{~s}$.

THE EARLY HISTORY OF CHARLES FAMES FOX. Library Edition, 8vo. I8s. Cabinet Edition, crown Svo. $6 s$.

Trollope.-NOVELS BY ANTHONY TROLLOPE.

THE WARDEN. Crown 8vo. Is. boards; Is. 6 d. cloth.

BARCHESTER TOWERS. Crown 8 vo. Is. boards ; Is. $6 d$. cloth.

Tuttle.-HISTORY OF PRUSSIA UNDER FREDERTC THE GREAT, 1740-I756. By Herbert Tuttle. With 2 Maps. 2 vols. crown 8 vo. I $8 s$.

Twells.-CollonUies oN PREACHING. By the Rev. H. Twells, M.A. Crown 8vo. 5 s.

Tyndall. - WORKSBY JOHN TYNDALL. FRAGMENTS OF SCIENCE. 2 vols. crown 8vo. I6s.

HEAT A MODE OFMOTION. Cr.8vo. i2s. [Continued above.
Tyndall.-WOR KS BY JOHNTYNDALL, Continued.

SOUND. With 204 Woodcuts. Crown 8vo. Ios. $6 d$.

RESEARCHES ON DIAMAGNETISM AND MAGNE-CRYSTALLIC ACTION. With 8 Plates and numerous Illustrations. Crown 8vo. I $2 s$.

ESSAYS ON THE FLOATING-MATTER OF THE AIR in relation to Putrefaction and Infection. With 24 Woodcuts. Crown 8vo. 7s. 6d.

LECTURES ON LIGHT, delivered in America in $\mathrm{IS}_{72}$ and 1873 . With 57 Diagrams. Crown 8vo. 5 s.

LESSONS IN ELECTRICITY AT THE ROYAL INSTITUTION, I875-76. With 58 Woodcuts. Crown 8vo. 2s. $6 d$.

NOTES OF A COURSE OF SEVEN LECTURES ON ELECTRICAL PHENOMENA AND THEORIES, delivered at the Royal Institution. Crown 8vo. Is. sewed, I s. $6 d$. cloth.

NOTES OF A COURSE OF NINE LECTURES ON LIGHT, delivered at the Royal Institution. Crown 8vo. Is. sewed, Is. 6d. cloth.

Faraday as a Discoverer. Fcp. 8vo. $3^{s .} 6 d$.

Unwin.-THE TESTING OF MATERIALS OF CoNSTRUCTION: a Text-Book for the Engineering Laboratory. By W. CAWTHORNe UNWIN, F.R.S. With 5 Plates and I4I Woodcuts. 8vo. 2Is.

Vignoles.-THE LIFE OF C. B. VIGNOLES, F.R.S. SOLDIER AND CIVIL ENGINEER. Compiled from Original Diaries, Letters, and Documents by his Son, Olinthus J. Vignoles, M.A. With several Original Illustrations and Portraits. 8vo. I6s.

Ville.-ON ARTIFICIAL MANURES, their Chemical Selection and Scientific Application to Agriculture. By GeORGES VILLE. Translated and edited by W. Crookes. With 3I Plates. 8vo. 21s.

Virgil.-PUBLI VERGILI MARONIS BUCOLICA, GEORGICA, EENEIS ; the Works of VirgIL, Latin Text, with English Commentary and Index. By B. H. KeNNEDy, D.D. Cr. 8 vo. IOs. $6 d$. THE ENNEID OF VIRGIL. Translated into English Verse. By Јон.v ConingTon, M.A. Crown Svo. $6 s$.

THE POEMS of VIRGIL. Translated into English Prose. By John ConingTON, M.A. Crown 8vo. $6 s$. 
Walker. - THE CORRECT CARD; or, How to Play at Whist; a Whist Catechism. By Major A. CAMPBELLWALKER, F.R.G.S. Fcp. 8vo. 2s. 6d.

Walpole.-HISTORY OF ENGLAND FROM THE CONCLUSION OF THE GREAT WAR IN ISI 5 . By SPENCER WALPOLE. 5 vols. 8 vo. Vols. I. and II. I815-1832, 36s. ; Vol. III. 1832-I 84 I, I8s.; Vols. IV. and V. $1841-1858,36 s$.

Waters. - PARISH REgISTERS IN $E_{N G L A N D:}$ their History and Contents. By Rolert E. Chester IVaters, B.A. 8vo. 5s.

Watts' DICTIONARY OF CHEAISTRY. Revised and entirely Re-written by $\mathrm{H}$. Forster Morley, M.A. D.Sc.; and M. M. Pattison Muir, M.A. F.R.S.E. Assisted by Eminent Contributors. To be published in 4 vols. 8 vo. Vols. I. \& II. A-Indigo. 42s. each.

Webb.-CELESTIAL OBfECTS FOR COMMON TELESCOPES. Ey the Rev. T. W. Webr. Crown 8vo. 9s.

Wellington.-LIFE OF THE DUKE of WELLINGTON. By the Rev, G. R. Gleig, M.A. Crown 8vo. $6 \mathrm{~s}$.

Wendt. - PAPERS ON MARITIAIE LEGISLATION, with a Translation of the German Mercantile Laws relating to Maritime Commerce. By ERNest EMIL WENDT, D.C.L. Royal 8vo. ŁI. I Is. 6d.

West.-WORKS BY CHARLES WEST, $M . D$. \&

LECTORES ON THE DISEASES OF INFANCY AND CHILDHOOD. 8vo. I8s.

THE MOTHER's MANUAL OF CHILDREN'S DISEASES. Crown 8vo. 2s. $6 d$.

Whately. - IVORKS BY E. JANE WHATELY.

ENGLISH SYNONYMS. Edited by R. Whately, D.D. Fcp. 8vo. $3^{\text {s. }}$

LIFE AND CORRESPONDENCE OF RICHARD WHATELY, D.D., late Archbishop of Dublin. With Portrait. Crown 8 vo. 10s. 6d.

Whately.-WORKS BY R. WHATELY, $D . D$.

ELEMENTS OF LOGIC. Cr. 8vo. 4s. 6 d.

ELEMENTS OF RHETORIC. Crown 8 vo. 4 s. $6 d$.

LESSONS ON REASONING. Fcp. 8vo. Is. $6 d$.

BACON'S ESSAYS, with Annotations. 8 vo. IOs. $6 d$.
Wilcocks.-THE SEA FISHERMAN. Comprising the Chief Methods of Hook and Line Fishing in the British and other Seas, and Remarks on Nets, Boats, and Boating. By J. C. Wilcocks. Profusely Illustrated. Crown 8vo. 6 s.

Wilks.-Lectures oN PATHOLOGICAL ANATOMY. By SAMUEL IVIlKS, M.D. F.R.S. and the late IVALTER Moxon, M.D. F.R.C.P. Third Edition, thoroughly Revised. By SAIIUEL WILKS, M.D. LL.D. F.R.S. Svo. ISs.

Williams.-PULmonary CONSUMPTION; its Etiology, Pathology, and Treatment. By C. J. B. Williams, M.D. and CHarles THeOdore Williams, M.A. M.D. Oxon. With 4 Coloured Plates and ro Woodcuts. Svo. 16s.

Williams. - MANUAL OF TELEGRAPHY, By W. WilliaMs, Superintendent of Indian Government Telegraphs. Illustrated by 93 Engravings. 8vo. 10s.6d.

Williams. - THE LAND OF $M Y$ FATHERS: a Story of Life in Wales. By T. Marchant Williams. Cr. 8 vo. $2 s .6 d$.

Willich. - POPULAR TABLES for giving Information for ascertaining the value of Lifehold, Leasehold, and Church Property, the Public Funds, \&c. By Charles M. Willich. Edited by I. Bence Jones. Crown 8 vo. Ios. $6 d$.

Willoughby. - EAST AFRICA AND ITS BIG GAME. The Narrative of a Sporting Trip from Zanzibar to the Borders of the Masai. By Capt. Sir JohN C. WillougiibY; Bart. Royal Horse Guards. With Postscript by Sir ROBERT G. IIARVEY, Bart. Illustrated by G. D. Giles and Mrs. Gordon Hake. Those of the latter from Photographs taken by the Author. Royal 8vo.

Wilson.-A MANUAL OF HEALTHSCIENCE. Adapted for Use in Schools. By ANDREW WiLson, F.R.S.E. F.L.S. \&c. With 74 Illustrations. Crown 8 vo. 2s. 6 d.

Witt.-WORKS BY PROF. WITT. Translated by Frances YounghusBand, THE TROfaN WAR. Crown Svo. $2 s$. MYTHS OF HELLAS; or, Greek Tales. Crown 8vo. 3s. 6 d.

THE WANDERINGS OF ULYSSES. Crown $8 v 0.3 s, 6 d$. 
Wood.-WORKS BY REV. J. G. WOOD.

HOMES WITHOUT HANDS; a Description of the Habitations of Animals, classed according to the Principle of Construction. With I 40 Illustrations. 8vo. IOs. $6 a$.

INSECTS AT HOME; a Popular Account of British Insects, their Structure, Habits, and Transformations. With 700 Illustrations. 8vo. Ios. $6 d$.

INSECTS ABROAD; a Popular Account of Foreign Insects, their Structure, Habits, and Transformations. With 600 Illustrations. 8vo. Ios. $6 d$.

BIBLE ANIMALS; a Description of every Living Creature mentioned in the Scriptures. With II 2 Illustrations, 8vo. IOs. $6 d$.

STRANGE DWELLINGS; a Description of the Habitations of Animals, abridged from 'Homes without Hands.' With 60 Illustrations. Crown 8 vo. 5 s.

ILLUSTRATED STABLE MAXIMS. To be hung in Stables for the use of Grooms, Stablemen, and others who are in charge of Horses. On Sheet, $4 s$.

OUT OF DOORS; a Selection of Original Articles on Practical Natural History. With I I Illustrations. Crown 8vo. 5 s.

PETLAND REVISITED. With Illustrations. Crown 8vo. $7 s, 6 d$.

The following books are extracted from the foregoing works by the Rev. J. G. WOOD :

SoCIAL Habitations and PARASITIC NESTS. With I8 Illustrations. Crown 8 vo. 2s. cloth extra, gilt edges.

THE BRANCH BUILDERS. With 28 Illustrations. Crown 8vo. 2s. $6 d$. cloth extra, gilt edges.

WILD ANIMALS OF THE BIBLE. With 29 Illustrations. Crown 8vo. 3s. $6 d$. cloth extra, gilt edges.

Domestic ANIMALS OF THE BIBLE. With 23 Illustrations. Crowu 8vo. 3 s. $6 d$. cloth extra, gilt edges.

BIRD-LIFE OF THE BIBLE. With 32 Illustrations. Crown 8vo. 3 s. $6 \%$. cloth extra, gilt edges.

WONDERFUL NESTS. With 30 Illustrations. Crown 8 vo. 3 s. $6 d$. cloth extra, gilt edges.

HOMES UNDER THE GROUND. With 28 Illustrations. Crown 8 vo. 3 s. $6 d$. cloth extra, gilt edges.
Wright.-HIP DISEASE IN CHILDHOOD, with Special Reference to its Treatment by Excision. By G. A. Wrighr, B.A. M.B.Oxon. F.R.C.S. Eng. With 48 Original Woodcuts. 8 vo, IOs. $6 d$.

Wylie. - HISTORY OF ENGLAND UNDER HENRY THE FOURTH. By JAMES Hamilton Wylie, M.A. one of Her Majesty's Inspectors of Schools. (2 vols.) Vol. I, crown 8vo. Ios. $6 d$.

Youatt. - WORKS BY

WILLIAM YOUATT.

THE HORSE. Revised and enlarged by W. Watson, M.R.C.V.S. 8vo. Woodcuts, $7 s .6 d$.

THE DoG. Revised and enlarged. 8vo. Woodcuts. 6s.

Younghusband. - WORKS $B Y$ FRANCES YOUNGHUSBAND.

THE STORY OF OUR LORD, TOLD IN SIMPLE LANGUAGE FOR CHILDREN. With 25 Illustrations on Wood from Pictures by the Old Masters, and numerous Ornamental Borders, Initial Letters, \&c. from Longmans' Illustrated New Testament. Crown 8vo. 2s. $6 d$.

The Story of Genesis. Crown 8vo. $2 s .6 d$.

Zeller. - WORKS $B Y$ DR. E. ZELLER.

HISTORY OF ECLECTICISM IN GREEK PHILOSOPHY. Translated by SARAH F. Alleyne, Crown 8vo. ios. $6 d$.

THE STOICS, EPICUREANS, AND SCEPTICS. Translated by the Rev. O. J. Reichei, M.A. Crown 8vo. I5s.

SOCRATES AND THE SOCRATIC SCHOOLS. Translated by the Rev. O. J. ReICHel, M.A. Crown 8vo. IOs. $6 d$.

Plato and the OLder ACADEMy. Translated by Sarah F. Alleyne and Alfred Goodwin, B.A. Crown 8vo. I8s.

THE $P_{R E-S O C R A T I C}$ SCHOOLS : a History of Greek Philosophy from the Earliest Period to the time of Socrates. Translated by SARAH F. Alleyne, 2 vols. crown 8vo. 3os.

OUTLINES OF THE HISTORY OF GREEK PHILOSOPHY. Translated by Sarah F. Alleyne and Evelyn AввоTт. Crown 8vo. ros. $6 d$. 


\section{EPOCHS OF ANCIENT HISTORY.}

Edited by the Rev. Sir G. W. Cox, Bart. M.A. and by C. SANkey, M.A. Io volumes, fcp. 8vo. with Maps, price 2s. $6 d$. each.

THE GRACCHI, MARIUS, AND SULLA. By A. H. Beesly, M.A. With 2 Maps.

THE EARLY ROMAN EMPIRE. From the Assassination of Julius Casar to the Assassination of Domitian. By the Rev. W. Wolfe CAPEs, M.A. With 2 Maps.

THR ROMAN EMPIRE OF THE SECOND CENtury, or the Age of the Antonines. By the Rev. W. WOLFE CAPES, M.A. With 2 Maps.

THE ATHENIAN EMPIRE FROM THE FLIGHT of Aer.xes to the Fall of Athens. By the Rev. Sir G. W. Cox, Bart. M.A. With 5 Maps.

THE RISE OF THE MACEDONIAN EMPIRE. By Arthur M. Curteis, M.A. With 8 Maps.
THE GREERS AND THB PERSIANS. By the Rev. Sir G. W. Cox, Bart. M.A. With 4 Maps.

ROMB to ITS CAPTURE BY TIE GAULS. By Wilhelm IhNe. With a Map.

THE Roman Triumvirates. By the Very Rev. Charles Merivale, D.D. Dean of Ely. With a Map.

THE SPARTAN AND TIIEBAN SUPREMACIES. By Charles Sankey, M.A. With 5 Maps.

RoMe aNd CARThage, the PUNIC WARs. By R. Bosworth' Sмith, M.A. With 9 Maps and Plans.

\section{EPOCHS OF MODERN HISTORY.}

Edited by C. Colbeck, M.A. I9 volumes, fcp. Svo. with Maps, price $2 s .6 d$. each.

THE BEGINNING OF THE MIDDLE AGES. By the Very Rev. Richard William Church, M.A. \&c. Dean of St. Paul's. With 3 Mraps.

THE NORMANS IN EUROPE. By Rev. A. H. Johnson, MI.A. With 3 Maps.

The Crusades. By the Rev. Sir G. W. Cox, Bart. M.A. With a Map.

TIIE EARLY PLANTAGENETS. By the Right Rev. W. StuBbs, D.D. Bishop of Oxford. With 2 Maps.

EDWARD THE THIRD. By the Rev. W. Warburton, M.A. With 3 Maps.

THE HOUSES OF LANCASTER AND YORK; with the Conquest and Loss of France. By JaMes Gairdner. With 5 Maps.

THE EARLY TUDORS, By the Rev, C. E. Moberly, M.A.

ThE ERA OF the PRotestant ReVOLUtion. By F. SеEвонм. With 4 Maps.

THE AGE OF ELIZABETH. By the Rev. M. Cretghton, M.A. LL.D. With 5 Maps.
THE FIRST TWO STUARTS aND THE PURItan Revolution, 1603-1660. By SAMUEL RawsoN GARDINER. With 4 Maps.

THE THIRTY YEARS' WAR, $1618-1648$. By Saniuel Raivson Gardiner. With a Map.

THE ENGLISH REstoration aND LOUIS XIV. 1648-I678. By OSMUND AIRY.

THE FALL OF THE STUARTS ; AND WESTERN Europe from 1678 to 1697 . By the Rev. EDIVARD HaLE, M.A. With Ir Maps and Plans.

THE AGE OF ANNE. By E. E. MIORRIS, M.A. With 7 Maps and Plans.

THE EARLY HANOVERIANS. By E. E. Morris, M.A. With 9 Maps and Plans.

FREDERICK THE GREAT AND THE SEVEN Year's'War. By F. W. Longman. With 2 Maps.

TIIE WAR OF AMERICAN INDEPENDENCE, 1775-1783. By J. M. Ludlow. With 4 Maps.

THE FRENCH REVOULTION, I7S9-1795. By Mrs. S. R. Gardiner. With 7 Maps.

THE EPOCH OF REFORM, I830-I850. By Justin McCarthy, M P.

\section{EPOCHS OF CHURCH HISTORY.}

Edited by the Rev. Mandeli CReighton. I6 volumes, fcp. Svo. price $2 s .6 d$. each.

THR ENGLISH CHURCH IN OTHER LANDS. By the Rev. H. W. TUCKer.

THE History OF THE REFORMATION IN England. By the Rev. George G. Perry.

THE CHURCH OF THE EARLY FATHERS. By Alfred Plummer, D.D.

THE EVANGELICAL REVIVAL IN THE Eighteenth'Century. By the Rev. J. H. OvarTON.

A HISTORY OF THE UNIVERSITY OF OXFORD. By the Hon. G. C. Brodrick, D.C.L.

A History of tite UNIVERSity of Cambridge. By J. Bass MUllinger, M.A.

TIIE ENGLISH CIIURCII IN THE MIDDLE Ages. By, Rev. W. Hunt, M.A.

THE ARIAN Controversy. By H. M.
THE COUNTER-REFORMATION. By A. W. WARD.

THE CHURCH AND THE ROMAN EMPIRE. By the Rev, A. CARR.

ThE CHURCH AND THE PURITANS, I5701660. By Henry OfFley Wakeman.

THE CIIURCH AND THE EASTERN EMPIRE. By the Rev. H. F. TOzER.

HILDEBRAND AND HIS TIMES. By the Rev. W. R. W. STEPHENS.

TIIE POPES AND TIIE HOIIENSTAUFEN. By Ugo Balzani.

THE GERMAN R'EFORIIATION: By Prof. mandell Creighton.

WYCLIFFE AND EARLY MOVEMENTS FOR Reform. By R. LANE POOLE. 
Pease (Alfred Edward). Travel and Sport in Africa. An Illustrated Record of 'Travel and Adventure in Search of Big Giame. 3 vols., roy. Sro., cloth extru, !ill, lops.s 1902

This work is an llhustrated fommal of Travel and Adrenture in scarch of Big Game in Africa, Somaliand, the Salman, and $A$ byssinia, during the ycars 1892-1901, and contains much practical information on the Big Gamc, Natural Iistory, and Opruithology of thesc countries.

ILSSI:N, B. H. W. N. McMillan's lixpeditions and Big (iame Hunt=

Ing in Sudan, Abyssinia, and British East Africa, Will 112 illus-

(wations and 1 map, printed. for privite circulation. 1906 (N.C.) 250

AFRICAN HUNTING. - Shots AND SNAPSHOTS IN BRITISH EAST AFRICA, by L. BenNet, LL.D. ; illustrated with 51 photographic illustrations and 2 maps in pocket, 8vo, cloth, NEW (pub. $12 / 6$ net), 6/6

W.II.MESLEY, LEO, Flying and sport in East Africa, illus.:. 1.920.. $106 \mathrm{n}$.

Wilson (Capt. H. A.)-A British Borderland: Service and Sport in Equatoria, Uganda, and the East African Protectorate, illustrated, 8vo, cloth, pp. 369 (12s net)

London, 1913

WILLOUGHBY (Major Sir John C.) EAST AFriCA and its BIG GaMe : NarRative of a SPORTING Trip from Zanzibar to the Borders of the MASAI, with map and plates, 8vo. cloth, 1889 $16 s$

Profit and Sport in British East Africa. Being a Second Edition, revised and cularged, of $A$ Colony in the Making. B! Capt. The Lord Crantvorth, M.C. Illustrated. Svo. 2Is, net.

Hadeira (I'. C.) Hunting in

British liast Africa, many illustrations, $8 \mathrm{vo}$, cloth, t.e.g., $5 \mathrm{~s}[101$ ]

Studley (J. T.). THE JOURNAL OF A SPORTING NOMAD. Sport in Newfoundland, East and West Africa, Canada, Alaska, and Iceland. Port.
lllus. 8vo. 1912 . 


2

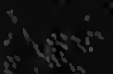

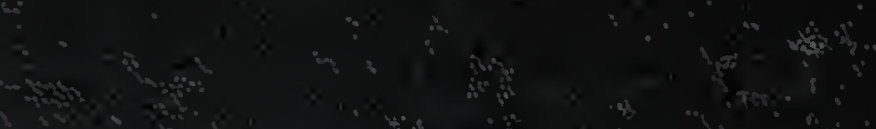

5.

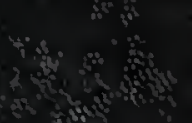
28. 2 क्ये

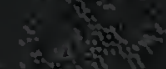

$-\cos 2 x^{2}$

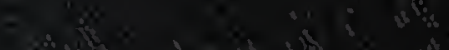

सर

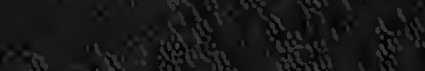

